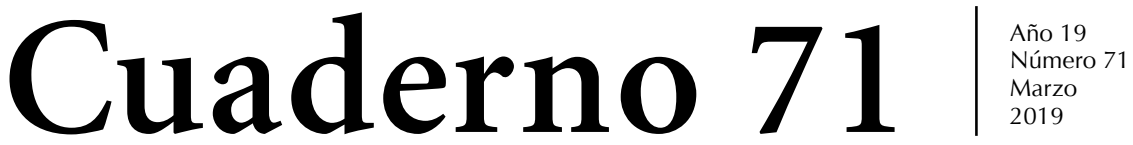

Cuadernos del Centro de Estudios en Diseño y Comunicación [Ensayos]

\section{Cruces entre Cultura y Diseño: repensando el diseño de los procesos culturales y los abordajes culturales del diseño}

Karen Avenburg y Marina Matarrese: Introducción. Cruces entre Cultura y Diseño: repensando el diseño de los procesos culturales y los abordajes culturales del diseño | Ivana Mihal: Estéticas, lecturas e industria del libro: el caso de los e-books | Laura Ferreño y María Laura Giménez: Desafíos actuales de las políticas culturales. Análisis de caso en el Municipio de Avellaneda | Silvia Benza: El Distrito de Diseño en la Ciudad de Buenos Aires: una mirada desde los usos de la cultura en contextos globales y locales | Natalia Aguerre: Las performances musicales en las misiones jesuitas de guaraníes | Julieta Infantino: Arte y Transformación social. El aporte de artistas (circenses) en el diseño de políticas culturales urbanas | Verónica Griselda Talellis, Elsa Alicia Martínez, Karen Avenburg y Alina Cibea: Investigación y gestión cultural: diseñando articulaciones | Verónica Paiva y Alejo García de la Cárcova: Wright Mills y su crítica al diseño de segunda posguerra. Los aportes de la sociología al mundo del diseño | Laura Zambrini: Diseño e indumentaria: una mirada histórica sobre la estética de las identidades de género | Bárbara Guershman: Marcas de shopping o de diseñador. Los procesos de adscripción en la moda.

Centro de Estudios en Diseño y Comunicación.

Facultad de Diseño y Comunicación. Universidad de Palermo. Buenos Aires. 


Cuadernos del Centro de Estudios en

Diseño y Comunicación

Universidad de Palermo.

Facultad de Diseño y Comunicación.

Centro de Estudios en Diseño y Comunicación.

Mario Bravo 1050. C1175ABT.

Ciudad Autónoma de Buenos Aires, Argentina.

www.palermo.edu

publicacionesdc@palermo.edu

\section{Director}

Oscar Echevarría

\section{Editora}

Fabiola Knop

Coordinación del Cuaderno $\mathbf{n}^{\circ} 71$

Karen Avenburg (D\&C, UP. Argentina)

Marina Matarrese (D\&C, UP. Argentina)

\section{Comité Editorial}

Lucia Acar. Universidade Estácio de Sá. Brasil.

Gonzalo Javier Alarcón Vital. Universidad Autónoma

Metropolitana. México.

Mercedes Alfonsín. Universidad de Buenos Aires.

Argentina.

Fernando Alberto Alvarez Romero. Universidad de

Bogotá Jorge Tadeo Lozano. Colombia.

Gonzalo Aranda Toro. Universidad Santo Tomás. Chile.

Christian Atance. Universidad de Buenos Aires. Argentina.

Mónica Balabani. Universidad de Palermo. Argentina.

Alberto Beckers Argomedo. Universidad Santo Tomás.

Chile.

Renato Antonio Bertao. Universidade Positivo. Brasil.

Allan Castelnuovo. Market Research Society. Reino

Unido.

Jorge Manuel Castro Falero. Universidad de la Empresa.

Uruguay.

Raúl Castro Zuñeda. Universidad de Palermo. Argentina.

Mario Rubén Dorochesi Fernandois. Universidad Técni-

ca Federico Santa María. Chile.

Adriana Inés Echeverria. Universidad de la Cuenca del

Plata. Argentina.

Jimena Mariana García Ascolani. Universidad Iberoame-

ricana. Paraguay.

Marcelo Ghio. Instituto San Ignacio. Perú.

Clara Lucia Grisales Montoya. Academia Superior de

Artes. Colombia.

Haenz Gutiérrez Quintana. Universidad Federal de Santa Catarina. Brasil.

José Korn Bruzzone. Universidad Tecnológica de Chile. Chile.

Zulema Marzorati. Universidad de Buenos Aires.

Argentina.

Denisse Morales. Universidad Iberoamericana Unibe.

República Dominicana.

\section{Universidad de Palermo}

Rector

Ricardo Popovsky

Facultad de Diseño y Comunicación

Decano

Oscar Echevarría

Secretario Académico

Jorge Gaitto
Nora Angélica Morales Zaragosa. Universidad Autónoma Metropolitana. México.

Candelaria Moreno de las Casas. Instituto Toulouse Lautrec. Perú.

Patricia Núñez Alexandra Panta de Solórzano. Tecnológico Espíritu Santo. Ecuador.

Guido Olivares Salinas. Universidad de Playa Ancha. Chile. Ana Beatriz Pereira de Andrade. UNESP Universidade Estadual Paulista. Brasil.

Fernando Rolando. Universidad de Palermo. Argentina. Alexandre Santos de Oliveira. Fundação Centro de Análise de Pesquisa e Inovação Tecnológica. Brasil.

Carlos Roberto Soto. Corporación Universitaria UNITEC.

Colombia.

Patricia Torres Sánchez. Tecnológico de Monterrey.

México.

Viviana Suárez. Universidad de Palermo. Argentina.

Elisabet Taddei. Universidad de Palermo. Argentina.

\section{Comité de Arbitraje}

Luís Ahumada Hinostroza. Universidad Santo Tomás. Chile.

Débora Belmes. Universidad de Palermo. Argentina.

Marcelo Bianchi Bustos. Universidad de Palermo.

Argentina.

Aarón José Caballero Quiroz. Universidad Autónoma Metropolitana. México.

Sandra Milena Castaño Rico. Universidad de Medellín. Colombia.

Roberto Céspedes. Universidad de Palermo. Argentina.

Carlos Cosentino. Universidad de Palermo. Argentina.

Ricardo Chelle Vargas. Universidad ORT. Uruguay.

José María Doldán. Universidad de Palermo. Argentina.

Susana Dueñas. Universidad Champagnat. Argentina.

Pablo Fontana. Instituto Superior de Diseño Aguas de La

Cañada. Argentina. 
Sandra Virginia Gómez Mañón. Universidad Iberoamericana Unibe. República Dominicana.

Jorge Manuel Iturbe Bermejo. Universidad La Salle. México.

Denise Jorge Trindade. Universidade Estácio de Sá. Brasil. Mauren Leni de Roque. Universidade Católica De Santos. Brasil.

María Patricia Lopera Calle. Tecnológico Pascual Bravo. Colombia.

Gloria Mercedes Múnera Álvarez. Corporación Universitaria UNITEC. Colombia.

Eduardo Naranjo Castillo. Universidad Nacional de Colombia. Colombia.

Miguel Alfonso Olivares Olivares. Universidad de Valparaíso. Chile.

Julio Enrique Putalláz. Universidad Nacional del Nordeste. Argentina.

Carlos Ramírez Righi. Universidad Federal de Santa Catarina. Brasil.

Oscar Rivadeneira Herrera. Universidad Tecnológica de Chile. Chille.

Julio Rojas Arriaza. Universidad de Playa Ancha. Chile. Eduardo Russo. Universidad Nacional de La Plata.

Argentina.

Virginia Suárez. Universidad de Palermo. Argentina. Carlos Torres de la Torre. Pontificia Universidad Católica del Ecuador. Ecuador.

Magali Turkenich. Universidad de Palermo. Argentina. Ignacio Urbina Polo. Prodiseño Escuela de Comunicación Visual y Diseño. Venezuela.

Verónica Beatriz Viedma Paoli. Universidad Politécnica y Artística del Paraguay. Paraguay.

Ricardo José Viveros Báez. Universidad Técnica Federico Santa María. Chile.

\section{Textos en inglés}

María Verónica Barzola

\section{Textos en portugués}

Mercedes Massafra

Diseño

Francisca Simonetti - Constanza Togni

1 Edición.

Cantidad de ejemplares: 100

Ciudad Autónoma de Buenos Aires, Argentina.

Marzo 2019.

Impresión: Artes Gráficas Buschi S.A.

Ferré 250/52 (C1437FUR)

Ciudad Autónoma de Buenos Aires, Argentina.

ISSN 1668-0227
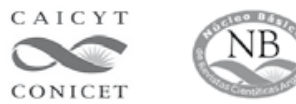

El Ministerio de Educación, Ciencia y Tecnología de la República Argentina, con la resolución No 2385/05 incorporó al Núcleo Básico de Publicaciones Periódicas Científicas y Tecnológicas -en la categoría Ciencias Sociales y Humanidades- la serie Cuadernos del Centro de Estudios en Diseño y Comunicación [Ensayos]. Facultad de Diseño y Comunicación de la Universidad de Palermo. En diciembre 2013 fue renovada la permanencia en el Núcleo Básico, que se evalúa de manera ininterrumpida desde el 2005. La publicación en sus versiones impresa y en línea han obtenido el Nivel 1 (36 puntos sobre 36).

\section{lat index}

La publicación Cuadernos del Centro de Estudios en Diseño y Comunicación [Ensayos] (ISSN 1668-0227) está incluida en el Directorio y Catálogo de Latindex.

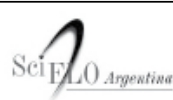

La publicación Cuadernos del Centro de Estudios en Diseño y Comunicación [Ensayos] (ISSN 1668-0227) pertenece a la colección de revistas científicas de SciELO.

\section{O Dialnet}

La publicación Cuadernos del Centro de Estudios en Diseño y Comunicación [Ensayos] (ISSN 1668-0227) forma parte de la plataforma de recursos y servicios documentales Dialnet.

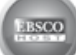

La publicación Cuadernos del Centro de Estudios en Diseño y Comunicación [Ensayos] (ISSN 1668-0227) se encuentra indexada por EBSCO.

Cuadernos del Centro de Estudios en Diseño y Comunicación [Ensayos] on line

Los contenidos de esta publicación están disponibles, gratuitos, on line ingresando en:

www.palermo.edu/dyc $>$ Publicaciones DC $>$ Cuader nos del Centro de Estudios en Diseño y Comunicación.

Prohibida la reproducción total o parcial de imágenes y textos. El contenido de los artículos es de absoluta responsabilidad de los autores. 



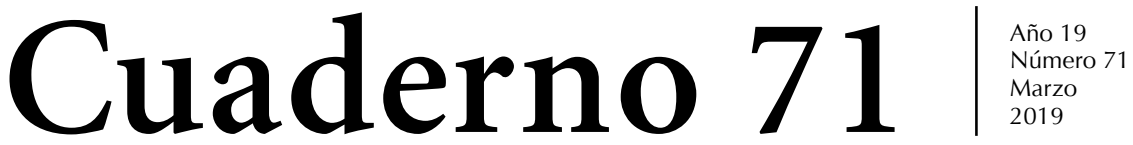

Cuadernos del Centro de Estudios en Diseño y Comunicación [Ensayos]

\section{Cruces entre Cultura y Diseño: repensando el diseño de los procesos culturales y los abordajes culturales del diseño}

Karen Avenburg y Marina Matarrese: Introducción. Cruces entre Cultura y Diseño: repensando el diseño de los procesos culturales y los abordajes culturales del diseño | Ivana Mihal: Estéticas, lecturas e industria del libro: el caso de los e-books | Laura Ferreño y María Laura Giménez: Desafíos actuales de las políticas culturales. Análisis de caso en el Municipio de Avellaneda | Silvia Benza: El Distrito de Diseño en la Ciudad de Buenos Aires: una mirada desde los usos de la cultura en contextos globales y locales | Natalia Aguerre: Las performances musicales en las misiones jesuitas de guaraníes | Julieta Infantino: Arte y Transformación social. El aporte de artistas (circenses) en el diseño de políticas culturales urbanas | Verónica Griselda Talellis, Elsa Alicia Martínez, Karen Avenburg y Alina Cibea: Investigación y gestión cultural: diseñando articulaciones | Verónica Paiva y Alejo García de la Cárcova: Wright Mills y su crítica al diseño de segunda posguerra. Los aportes de la sociología al mundo del diseño | Laura Zambrini: Diseño e indumentaria: una mirada histórica sobre la estética de las identidades de género | Bárbara Guershman: Marcas de shopping o de diseñador. Los procesos de adscripción en la moda.

Centro de Estudios en Diseño y Comunicación.

Facultad de Diseño y Comunicación. Universidad de Palermo. Buenos Aires. 
Cuadernos del Centro de Estudios en Diseño y Comunicación. [Ensayos], es una línea de publicación cuatrimestral del Centro de Estudios en Diseño y Comunicación de la Facultad de Diseño y Comunicación de la Universidad de Palermo. Los Cuadernos reúnen papers e informes de investigación sobre tendencias de la práctica profesional, problemáticas de los medios de comunicación, nuevas tecnologías y enfoques epistemológicos de los campos del Diseño y la Comunicación. Los ensayos son aprobados en el proceso de referato realizado por el Comité de Arbitraje de la publicación.

Los estudios publicados están centrados en líneas de investigación que orientan las acciones del Centro de Estudios: 1. Empresas y marcas. 2. Medios y estrategias de comunicación. 3. Nuevas tecnologías. 4. Nuevos profesionales. 5. Diseño y producción de objetos, espacios e imágenes. 6. Pedagogía del diseño y las comunicaciones. 7. Historia y tendencias.

El Centro de Estudios en Diseño y Comunicación recepciona colaboraciones para ser publicadas en los Cuadernos del Centro de Estudios [Ensayos]. Las instrucciones para la presentación de los originales se encuentran disponibles en: http://fido.palermo.edu/servicios_dyc/publicacionesdc/ vista/instrucciones.php

Las publicaciones académicas de la Facultad de Diseño y Comunicación de la Universidad de Palermo actualizan sus contenidos en forma permanente, adecuándose a las modificaciones presentadas por las normas básicas de estilo de la American Psychological Association - APA. 
Cuadernos del Centro de Estudios en

Sumario

Diseño y Comunicación [Ensayos] No 71

ISSN 1668-0227

Facultad de Diseño y Comunicación.

Universidad de Palermo. Buenos Aires.

Marzo 2019.

Cruces entre Cultura y Diseño: repensando el diseño de los procesos culturales y los abordajes culturales del diseño

Introducción. Cruces entre Cultura y Diseño: repensando el diseño de los procesos culturales y los abordajes culturales del diseño

Karen Avenburg y Marina Matarrese. .pp. 11-19

Eje 1. Diseño de políticas culturales y políticas culturales del diseño

Estéticas, lecturas e industria del libro: el caso de los e-books

Ivana Mihal.

.pp. 21-31

Desafíos actuales de las políticas culturales. Análisis de caso en el

Municipio de Avellaneda

Laura Ferreño y María Laura Giménez

.pp. 33-49

El Distrito de Diseño en la Ciudad de Buenos Aires: una mirada desde los usos de la cultura en contextos globales y locales

Silvia Benza. .pp. 51-59

Eje 2. Diseño, expresiones artísticas y políticas culturales

Las performances musicales en las misiones jesuitas de guaraníes

Natalia Aguerre.

.pp. 61-74

Arte y Transformación social. El aporte de artistas (circenses) en el diseño de políticas culturales urbanas

Julieta Infantino.

.pp. $75-91$ 
Investigación y gestión cultural: diseñando articulaciones

Verónica Griselda Talellis, Elsa Alicia Martínez, Karen Avenburg y

Alina Cibea.

Eje 3. El diseño como campo histórico, social y cultural

Wright Mills y su crítica al diseño de segunda posguerra. Los aportes de la sociología al mundo del diseño

Verónica Paiva y Alejo García de la Cárcova.

Diseño e indumentaria: una mirada histórica sobre la estética de las identidades de género

Laura Zambrini.

Marcas de shopping o de diseñador. Los procesos de adscripción en

la moda

Bárbara Guershman.

.pp. 129-143

Publicaciones del Centro de Estudios en Diseño y Comunicación. .pp. 145-167

Síntesis de las instrucciones para autores. ..pp. 168 
Fecha de recepción: marzo 2017 Fecha de aceptación: octubre 2017 Versión final: marzo 2019

\section{Introducción. Cruces entre Cultura y Diseño: repensando el diseño de los procesos culturales y los abordajes culturales del diseño}

Karen Avenburg ${ }^{\star}$ y Marina Matarrese ${ }^{\star *}$

\begin{abstract}
Resumen: En este artículo nos ocupamos de introducir tanto el libro como la Línea de Investigación en la que se desarrolla. Partimos de observar que el campo cultural y el campo del diseño, en principio ámbitos de formación, acción e investigación diferenciados, se atraviesan mutuamente, tanto en el plano conceptual como en el nivel de las prácticas. Como investigadoras oriundas de las ciencias antropológicas, ponemos el foco en el concepto de cultura y partimos de allí para atender a sus entrecruzamientos con el diseño. Por un lado, entendiendo a la cultura como procesos activos de construcción y disputa por los significados (Wright 2007), podemos pensar que el diseño en sus diferentes vertientes y manifestaciones (diseños de productos, de espacios, de artes escénicas, de artes audiovisuales, de estrategias de comunicación, etc.) como campos de disputas por la construcción de sentidos. Además, el diseño se desarrolla siempre en un marco sociocultural. Por el otro lado, es factible considerar a los objetos, prácticas y representaciones culturales en clave del diseño que les da forma, de las valoraciones que esos diseños recrean, modifican o sostienen, y de las políticas que los direccionan.
\end{abstract}

Palabras clave: Cultura - Diseño - Antropología.

[Resúmenes en inglés y portugués en las páginas 18-19]

${ }^{(*)}$ Dra. en Ciencias Antropológicas (UBA). Docente e investigadora de la Universidad Nacional de Avellaneda (Departamento de Humanidades y Artes). Forma parte del Cuerpo Académico del Doctorado en Diseño y dirige la Línea de Investigación Cruces entre Cultura y Diseño de la Universidad de Palermo.

${ }^{(*)}$ Dra. en Ciencias Antropológicas (UBA). Investigadora Asistente del Consejo Nacional de investigaciones Científicas y Técnicas (CONICET/UBA). Docente de la Maestría en Gestión del Diseño y del Doctorado en Diseño de la Universidad de Palermo.

\title{
Introducción
}

En este número de Cuadernos del Centro de Estudios en Diseño y Comunicación buceamos en los puntos de intersección entre los campos de la cultura y el diseño. En consecuencia incluimos aquí artículos que, desde diferentes ángulos, exploran las múltiples 
relaciones entre los conceptos de cultura y diseño, ya sea reflexionando acerca de las concepciones culturales que subyacen al diseño o analizando las disputas por los sentidos que están implicadas en diferentes tipos de diseño -es decir, abordando el diseño desde una perspectiva cultural-, o dando cuenta de los distintos diseños que hay detrás de las variadas manifestaciones culturales y de los diversos actores del campo de la cultura.

Partimos de observar que el campo cultural y el campo del diseño, en principio ámbitos de formación, acción e investigación diferenciados, se atraviesan mutuamente, tanto en el plano conceptual como en el nivel de las prácticas. Como investigadoras oriundas de las ciencias antropológicas, ponemos el foco en el concepto de cultura y partimos de allí para atender a sus entrecruzamientos con el diseño. Lo antedicho nos obliga a repensar teóricamente a qué nos referimos mediante el tan discutido término "cultura".

El concepto de cultura tiene una larga trayectoria en la que se fueron gestando diversas acepciones indisociables de los contextos histórico-sociales -y lingüísticos- de su desarrollo (Williams, 1976; Neufeld, 1994; Kuper, 2001; Cuche, 2002; Santillán Guemes, 2007). Muy sucintamente podemos organizar estas trayectorias en torno a tres grandes líneas: en primer lugar, una concepción humanista de cultura ligada al pensamiento iluminista -que suponía un mejoramiento progresivo-. En segundo lugar, una idea plural del concepto -iniciada por Herder (1784-91, en Williams, 1976) - vinculada al romanticismo; esta idea resalta la particularidad de las distintas culturas nacionales, cuestionando la postura universalista y la idea de progreso lineal propias del iluminismo. Y finalmente, un uso restringido del término cultura, que se refiere únicamente a las actividades intelectuales y artísticas, en especial a estas últimas -a veces incluso a "ciertas" artes y saberes relacionados con una idea elitista de "lo culto"-.

Particularmente en el campo científico, podemos identificar una historia de discusiones con respecto al concepto de cultura por mucho tiempo monopolizada por la antropología. Esta ciencia, surgida en el contexto colonial para describir, explicar, analizar o comprender la diversidad cultural, tuvo su primera definición -según el "relato mítico", como dice Neufeld (1994: 391)-, tributaria las dos primeras líneas de pensamiento mencionadas. La misma fue desarrollada por Tylor (1871) en Primitive Culture.

Si bien no vamos a abundar en las diversas definiciones y discusiones que han acompañado el concepto a lo largo de su historia (ver Neufeld, 1994; Kuper, 2001; Cuche, 2002; Wright, 2007; entre otros) $)^{1}$, queremos dejar en claro que no se trata de una discusión acabada ni hay una única definición concensuada. Con frecuencia se cita la autoridad de "La definición antropológica de cultura" y sólo podemos preguntarnos a cuál de ellas se estarán refiriendo. Como bien observa Susan Wright (2007), el mismo concepto de cultura es un campo de disputas.

Sin adentrarnos entonces en cada una de las acepciones, podemos destacar que las actuales perspectivas de cultura buscan superar algunas de las grandes dificultades de sentido con las que se ha cargado este concepto:

En primer lugar se describió a la cultura desde una mirada holística. Si bien ese "todo complejo" que mencionaba Tylor permitió inicialmente reconocer que toda sociedad y todo grupo social tienen cultura, el concepto se tornó difuso por su misma amplitud, generando un "pantano conceptual” (Geertz, 2003, p. 20). 
En segundo término, se la asumió en tanto concepción homogeneizadora. En efecto, algunas de las grandes críticas a las ideas clásicas de cultura se vinculan con el reconocimiento de que aquello que conocemos como "la cultura" de un grupo no es necesariamente compartido por todos, pues hay diferencias -en concepciones, intereses, deseos, ideas, prácticas- en todo grupo social.

En tercer lugar y asociado al punto anterior, la cultura fue vinculada con una supuesta armonía por quienes la compartían; por el contrario, la diferencia y el conflicto parecen ser una constante en las distintas sociedades.

En cuarto término, se promovió una concepción esencialista de la cultura dado que, en muchas ocasiones, se ha tendido a creer que las prácticas y representaciones responden a una supuesta "esencia" -vinculada a un pasado prístino- y que el alejamiento de esa lista de rasgos implica el alejamiento de su cultura².

En quinto lugar y vinculado con el término recién mencionado está la consideración de la cultura como un fenómeno estático cuya modificación implica su "pérdida”; sin embargo, no hay sociedad sin movimiento ni transformación -ni siquiera las clásicas sociedades descriptas por los primeros antropólogos--.

Finalmente -aunque no se agotan aquí las limitaciones señaladas al concepto ${ }^{3}$ - se estableció la idea de cultura como "algo" claramente delimitado, que puede tener o no vínculo con el exterior, pero cuyas fronteras están bien definidas.

Limitaciones como las aquí señaladas son las que llevaron a algunos autores a criticar las "normas clásicas" de la antropología y su complicidad con el imperialismo (Rosaldo, 1991), a "escribir contra la cultura" (Abu-Lughod, 2012) poniendo en evidencia la legitimación de las jerarquías que ha operado a partir de los supuestos de homogeneidad, atemporalidad y coherencia, o incluso a desarrollar conceptos alternativos, como el de "configuraciones culturales" (Grimson, 2011). Sin negar la riqueza y capacidad analítica de propuestas como estas, creemos que el concepto de cultura, entendido -tal como veremos- en su dinamismo y heterogeneidad, es útil para dar cuenta de la complejidad de la experiencia humana. Más aún, como observa Abu-Lughod (2006, p. 132), lo antedicho "no niega que la noción de tener una cultura, o ser una cultura, se haya vuelto políticamente crucial para muchas comunidades" -en muchos casos las que fueron etiquetadas como tales por antropólogos-. Además, este concepto es útil para analizar una serie de conquistas en términos de derechos de diversas minorías (mujeres, negros, indígenas) que, en el marco latinoamericano, se reconocieron desde la década de 1970 a esta parte (Iturralde, 1997; Carrasco, 2000; 2010; Carrasco y Briones, 1996; GELIND, 1999, 2000, 2004 у 2005; Matarrese, 2011). Muchas veces ese acceso a derechos especiales se logró apelando política y estratégicamente a la pertenencia a determinada cultura. Se trata en parte de aquello que Rita Segato (2007) ha denominado "politización de las identidades"; esta politización abre vías de reconocimiento y efectivización de derechos cuando, en lugar de caer en formatos cristalizados y "preformateados", es guiada por la "diferencia de horizontes culturales en un sentido profundo y radical” (2007, p. 17). Esta diferencia, explica Segato, no se define "con referencia a contenidos substantivos en términos de 'costumbres' supuestamente tradicionales, cristalizadas, inmóviles e impasibles frente al devenir histórico, sino como una diferencia de meta y perspectiva por parte de una comunidad o un pueblo" (2007, p. 18). 
En este contexto conceptual complejo, es menester presentar las perspectivas a las que adherimos, es decir, en qué estamos pensando cuando nos referimos al concepto de cultura. Dentro de las diferentes líneas que se han desarrollado, actualmente hay cierto consenso en la relevancia de aquello que Néstor García Canclini (2005) identifica como una "definición sociosemiótica de la cultura que abarque el proceso de producción, circulación y consumo de significaciones en la vida social" (2005, p. 35). Asimismo y en respuesta a las limitaciones recién señaladas, destacamos dentro del abanico de las significaciones en la vida social, aquello que Susan Wright (2007) identifica como los nuevos significados de cultura, que reconocen su heterogeneidad, dinamismo, yuxtaposición e historicidad. Las culturas están atravesadas por diferentes niveles contextuales - pensemos en los Estados nacionales, los movimientos transnacionales, los diferentes fenómenos vinculados con la globalización-, en un marco de interrelaciones signadas por el acceso desigual a las usinas de poder. En suma, se consideran a las culturas, en este contexto, como procesos activos y dinámicos de construcción y disputa por los significados (Wright 2007), permeados de inconsistencias, conflictos, contradicciones.

A partir de lo antedicho, podemos pensar que el diseño en sus diferentes vertientes y manifestaciones -diseños de productos, de espacios, de artes escénicas, de artes audiovisuales, de estrategias de comunicación, etc.- se desarrolla siempre en un marco sociocultural. Esto significa que los productos, espacios, artes y modos de comunicación tienen características específicas que son fruto de perspectivas, significaciones y prácticas social e históricamente construidas; que están ancladas en experiencias concretas y pueden estar asociadas a grupos específicos pero no por ello dejan de estar conectadas con otros niveles contextuales; que implican tramas de sentidos (como dice Geertz 2003), pero sentidos cambiantes, reforzados, compartidos, disputados, negociados -es decir, inmersos en procesos de hegemonía ${ }^{4}-$.

A la vez, es factible considerar a los objetos, prácticas y representaciones culturales en clave del diseño ${ }^{5}$ que les da forma y función, de las valoraciones que los recrean, modifican o sostienen, y de las políticas que los direccionan. En los artículos que siguen, buscamos poner el foco en los diseños posibles que se encuentran imbricados en las diferentes expresiones culturales - diseño de políticas culturales, perspectivas estéticas que guían la producción cultural, movimientos políticos expresados artísticamente, manifestaciones identitarias referenciadas en la indumentaria, entre otros-, y en los sentidos y disputas de los que emergen los diversos diseños de productos, prácticas, imágenes, sonidos. Todo ello permitirá repensar las configuraciones, los alcances y los límites de poner en diálogo dos conceptos diferentes y a la vez centrales en la vida social contemporánea.

Hemos articulado los trabajos que siguen en torno a tres ejes:

\section{Eje 1. Diseño de políticas culturales y políticas culturales del diseño}

En este eje se concentran las contribuciones que conceptualizan los cruces entre las diversas dimensiones del diseño, abordadas en casos de estudios particulares y su inescindible impacto social. El estudio de Ivana Mihal, Estéticas, lecturas e industria del libro: el caso de los e-books, discute problemáticas vinculadas con las políticas de lectura, la industria 
del libro y la inclusión digital, desde una perspectiva antropológica. La autora dirige su mirada hacia las diferencias entre el libro digital o $e$-book y el texto impreso. La digitalización, observa, es un proceso que no sólo afecta el soporte del texto como producto final, sino también su diseño, producción, circulación y consumo. Esto se debe a que este proceso está atravesado tanto por la tecnología como por diferentes concepciones estéticas y discursos respecto a la lectura.

El trabajo de Laura Ferreño y María Laura Giménez, titulado Desafíos actuales de las políticas culturales. Análisis de caso en el Municipio de Avellaneda, analiza las tensiones que se generan entre los destinatarios de políticas públicas socio-culturales inclusivas y las instituciones gubernamentales que las diseñan y ejecutan. Indagando en el impacto de las políticas culturales dirigidas a grupos poblacionales en riesgo, se plantea la importancia de revisar, en el diseño de políticas, las estrategias de comunicación y de evaluación, a fin de poder articularlas adecuadamente con las necesidades de sus destinatarios. Incluimos en este eje el aporte de Silvia Benza, con su artículo El Distrito de Diseño en la Ciudad de Buenos Aires: una mirada desde los usos de la cultura en contextos globales y locales. La autora no solo analiza el diseño de políticas culturales, sino que las políticas observadas en este caso son, a su vez, del universo del diseño. Específicamente estudia el Distrito de Diseño de CABA y reflexiona sobre la relación que en este caso se da entre políticas culturales y políticas de desarrollo urbano. Para ello el análisis retoma las discusiones en torno a la instrumentalidad y el valor público de la cultura.

\section{Eje 2. Diseño, expresiones artísticas y políticas culturales}

En este eje también se estudia el diseño de políticas culturales, pero se incluyen artículos que ponen el foco específicamente en prácticas artísticas. Puntualmente el aporte de Natalia Aguerre, con su trabajo Las performances musicales en las misiones jesuitas de guaraníes, analiza el lugar de las performances de música y danza como estrategias de los jesuitas para transformar a los guaraníes, tanto en sus corporalidades como en sus creencias -ambas interrelacionadas-. En este caso se presenta el diseño de una forma de intervención social desarrollada por los jesuitas que empleaba la enseñanza en las misiones como una estrategia política tendiente a transmitir conceptos morales, construir modelos de conducta e incorporar hábitos cuyo conjunto contribuía a generar sentidos de pertenencia a un colectivo guaraní adaptado a las modalidades requeridas por el poder colonial. Por su parte Julieta Infantino, en el artículo Arte y Transformación social. El aporte de artistas (circenses) en el diseño de políticas culturales urbanas, analiza la contribución de colectivos artísticos -en particular los circenses-al diseño e implementación de una política cultural superadora de intervenciones caracterizadas como economicistas y mercantilistas; en oposición a ellas, estos colectivos buscan disputar inequidades mediante estrategias redistributivas, garantizando igualdad en el acceso, la participación y la producción cultural urbana. Se centra específicamente en el caso de Circo del Sur para mostrar la resistencia, negociación y utilización estratégica de los paradigmas que en las últimas décadas han dominado a las políticas culturales. La producción de Verónica Talellis, Elsa Martínez, Karen Avenburg y Alina Cibea, titulada Investigación y gestión cultural: diseñando arti- 
culaciones, explora el diálogo entre la gestión cultural y la investigación sociocultural, en base a su experiencia de trabajo sobre los proyectos y programas de orquestas infantiles y juveniles. A partir de observar estas políticas culturales que involucran la formación musical desde la práctica orquestal con la inclusión, integración o transformación social, se pone el foco en los aportes que puede hacer la investigación para el diseño y evaluación de la gestión, así como en la necesidad de que la primera se diseñe en diálogo con la segunda.

\section{Eje 3. El diseño como campo histórico, social y cultural}

En este eje, en el que se ubican los aportes que desde diversas perspectivas (históricas, sociales y culturales) dan cuenta de manifestaciones particulares del diseño, contamos con el aporte de Verónica Paiva y Alejo García de la Cárcova, con el texto Wright Mills y su crítica al diseño de segunda posguerra. Los aportes de la sociología al mundo del diseño. Los autores proponen un cruce entre la sociología y el diseño, puntualmente analizando dos producciones de Charles Wright Mills. El estudio pone el acento en la reconfiguración propuesta para el rol del diseño en un contexto histórico tan cambiante en sus procesos productivos y de consumo como el de los Estados Unidos desde la crisis del '29 y en especial desde la Segunda Posguerra. A partir de esta crítica se desarrollan discusiones relevantes en torno al rol social de los diseñadores, a su vínculo con "el aparato cultural" y el "aparato comercial", y a sus intervenciones en el mundo del arte y el mundo industrial. Por su parte, Laura Zambrini, en Diseño e indumentaria: una mirada histórica sobre la estética de las identidades de género, historiza el campo del diseño de indumentaria. Lo hace desde una perspectiva social y en particular de género. Demostrando que el diseño de indumentaria "habla de" y a la vez produce a la sociedad en la que se desarrolla, la autora analiza este campo en términos sociológicos y semióticos. Finalmente, el artículo Marcas de shopping o de diseñador. La adscripcion en la moda, de Bárbara Guershman, se mueve dentro de este mismo campo para analizar, a partir de un abordaje etnográfico, los procesos de adscripción de productores de indumentaria que buscan diferenciarse a partir de categorías como la de "marca" y "diseñador". La autora discute cómo a partir de esta adscripción se encabalgan diversos criterios en cuanto a la producción y comercialización de la indumentaria.

\section{Notas}

1. Se puede hallar también una revisión de las nociones de cultura y política en la exploración realizada por Schneider y Avenburg (2015) para discutir diferentes desarrollos del concepto de cultura política. Asimismo sobre diversos aspectos de las políticas culturales ver Bayardo yMihal (2013) y Mihal (2013).

2. El clásico libro de Fredrick Barth (1976) se considera uno de los pilares fundamentales del cuestionamiento de los grupos étnicos como "portadores" de cultura.

3. En Rosaldo (1991) se puede encontrar una interesante crítica y caracterización de las "normas clásicas" que dieron lugar a estas ideas de cultura. 
4. Adoptamos el concepto de hegemonía de Antonio Gramsci (1971), quien la concibe como una arena cultural de dominación y consenso que expresa la lucha entre distintos sectores sociales. Dentro de esta profusa temática, rescatamos los valiosos aportes de Raymond Williams (1980) referidos a este término. Este autor sostiene que la hegemonía "tiene que ser continuamente renovada, recreada, defendida y modificada. [Asimismo] Es también continuamente resistida, limitada, alterada, desafiada por presiones que de ninguna manera le son propias" (1980: 134).

5. Los debates académicos que teorizan acerca de una temática tan compleja y amplia como "el diseño" exceden ampliamente el marco posible de abordaje de estas páginas; para ello se sugiere consultar los números 63,69 y 70 de esta misma colección, entre otros.

\section{Referencias bibliográficas}

Abu-Lughod, L. (2006). “Interpretando la (s) cultura (s) después de la televisión”. En: Iconos, 24. Quito: FLACSO. Ecuador. pp. 119--141.

Abu-Lughod, L. (2012). “Escribir contra la cultura”. En: Andamios. Revista de Investigación Social, vol. 9, núm. 19: 129-157. Universidad Autónoma de la Ciudad de México. Distrito Federal, México.

Barth, F. (editor). (1976). Los grupos étnicos y sus fronteras. México, Fondo de Cultura Económica, pp. 9-20.

Bayardo, R.y I. Mihal. (2013b) "Argentina en la Feria del Libro de Frankfurt. Notas sobre Política Cultural”. Revista Publicar en Antropología y en Ciencias Sociales, N XIII, pp. 9-29. Buenos Aires: Colegio de Graduados de Antropología de la República Argentina. Disponible en: http://ppct.caicyt.gov.ar/index.php/publicar/article/view/1627/3151

Carrasco, M. (2000). Los Derechos de los Pueblos Indígenas en Argentina. Serie Documentos en Español Número 30. Buenos Aires: IWGIA -Ed. Vinciguerra.

Carrasco, M. (2010). Tierras Duras. Historias, Organización y Lucha por el territorio en el Chaco Argentino. Documentos de IWGIA. Buenos Aires: IWGIA.

Carrasco, M. y C. Briones (1996). La Tierra que nos quitaron. Reclamos Indígenas en Argentina. Serie Documentos en Español Número 18. Buenos Aires: IWGIA y Asociación Comunidades Aborígenes Lhaka Honat.

Cuche, D. (2002). La noción de cultura en las ciencias sociales. Buenos Aires: Nueva Visión. García Canclini, N. (2005). Diferentes, desiguales y desconectados. Barcelona: Gedisa.

GELIND (Grupo de Estudios en Legislación Indígena) (1999). "Etnografía del discurso jurídico sobre lo indígena. La resolución 4811/96 desde la pragmática”. Publicar en Antropología y Ciencias Sociales VII (8): 51-68.

GELIND (2000). "El espíritu de la ley y la construcción jurídica del sujeto "pueblos indígenas"”. VI Congreso Argentino de Antropología Social. Mar del Plata. Argentina.

GELIND (2004). "Possible Indigenism or the Limits of the Constitutional Amendment in Argentina”. En: A. Das Neves (comp.), Indigenous Legislation. Pp. 122-131. London: Routledge .

GELIND (2005). "Reconocimientos Legales y Vulnerabilidad Socioambiental en Poblaciones Nativas de Argentina”. IV Reunión de Antropología del MERCOSUR. Uruguay. 
Geertz, C. (2003). "Descripción densa: hacia una teoría interpretativa de la cultura”. En La interpretación de las culturas, Barcelona, Gedisa editorial. pp. 19-32.

Gramci, A. [1929/35] (1971). Selection From The Prision Notebooks. Quintin Hoare y Geoffrey Smith (comps.). New York: International Publishers.

Grimson, A. (2011). Los límites de la cultura. Crítica de las teorías de la identidad. Buenos Aires: Siglo XXI Editores.

Iturralde, D. (1997). “Demandas Indígenas y reforma legal: retos y paradojas”. Alteridades 7 (14): 81-98. Volumen Estado Nacional, Autodeterminación y Autonomía.

Kuper, A. (2001). “Introducción: Guerras de cultura”, en Cultura. La versión de los antropólogos, Barcelona: Paidós. pp. 20-38.

Matarrese, M. (2011). "Disputas y negociaciones en torno al territorio pilagá (provincia de Formosa)". Tesis Doctoral inédita, Facultad de Filosofía y Letras, Buenos Aires: Universidad de Buenos Aires.

Mihal, I. (2013) “Actores y procesos en la gestión de la Bibliodiversidad". Revista Alteridades, $\mathrm{N}^{\circ} 45$, pp. 123-136. México: Universidad Autónoma Metropolitana - Unidad Iztapalapa.

Neufeld, M. R. (1994). “Crisis y vigencia de un concepto: la cultura en la óptica de la antropología”. En Mirta Lischetti (comp.) Antropología. Buenos Aires: Eudeba.

Rosaldo, R. (1991). “La erosión de las normas clásicas". En Rosaldo, Renato Cultura y verdad. México: Grijalbo.

Santillán Güemes, R. (2007). "Hacia un concepto operativo de cultura”. En: Artes e industrias culturales: debates contemporáneos en Argentina / coordinador Oscar Moreno. Caseros: Editorial de la Universidad Nacional de Tres de Febrero, 2010, pp. 35-49.

Schneider, C. y Avenburg, K. (2015). "Cultura política: un concepto atravesado por dos enfoques”. En POSTData. Revista de Reflexión y Análisis Político 20, № 1: 109-131. Buenos Aires.

Segato, Rita. (2007). La Nación y sus otros. Buenos Aires: Prometeo.

Tylor, E. B. (1871). Primitive Culture. Chicago: University of Chicago Press.

Williams, R. (1976). “¿Qué significa cultura?”. En Keywords: A Vocabulary of Culture and Society. London: Fontana. Pp. 76 a 82. Traducido por Tomás Austin M. 1990, (mimeo). Disponible en: http://tijuana-artes.blogspot.com/2005/03/que-significa-cultura.html

Williams, R. (1980). “Hegemonía”. En Marxismo y Literatura, Barcelona, Península. Pp. 129-136.

Wright, S. (2007). “La politización de la cultura”. En Constructores de otredad: una introducción a la antropología social y cultural, Boivin, Mauricio, Ana Rosato y Victoria

\begin{abstract}
In this article we introduce both the book and the research perspective in which it is included. Even though the cultural and design fields are different areas of study, research, and action, they intersect each other, both at the level of concepts and at the level of practices. As anthropologists, we mainly focus on the concept of culture and discuss its intersections with the field of design. On the one hand, understanding culture as an active and disputed process of construction of meanings (Wright 2007), we consider design, in its different dimensions and manifestations (designs of products, spaces, performing arts,
\end{abstract}


audio-visual arts, communication strategies, etc.), as a field of disputes over perspectives and practices. Moreover, any design is always developed in a sociocultural framework. On the other hand, we can analyse the objects, practices and cultural representations considering the design that shapes them, the valuations those designs recreate, modify or sustain, and the policies that shape them.

Key words: Culture - Design - Anthropology.

Resumo: Neste artigo, nos esforçamos para apresentar tanto o livro como a Linha de Pesquisa em que ele é desenvolvido. Começamos observando que o campo cultural e o campo do design, em princípio, campos diferenciados de treinamento, ação e pesquisa, se cruzam, tanto no nível conceitual como no nível de práticas. Como pesquisadores das ciências antropológicas, colocamos o foco no conceito de cultura e começamos a partir de lá para atender às suas interseções com o design. Por um lado, entendendo a cultura como processos ativos de construção e disputa sobre significados (Wright, 2007), podemos pensar que o design em seus diferentes aspectos e manifestações (design de produtos, espaços, artes cênicas, artes audiovisuais), de estratégias de comunicação, etc.) como campos de disputas para a construção de significados. Além disso, o design sempre é desenvolvido em um quadro sociocultural. Por outro lado, é viável considerar os objetos, práticas e representações culturais na chave do design que lhes dá forma, das avaliações que esses projetos recriam, modificam ou sustentam e das políticas que os orientam.

Palavras chave: Cultura - Design - Antropologia. 

Fecha de recepción: marzo 2017 Fecha de aceptación: octubre 2017 Versión final: marzo 2019

\section{Estéticas, lecturas e industria del libro: el caso de los e-books}

Ivana Mihal *

Resumen: Este artículo se inscribe dentro de una línea de trabajo que aborda, desde una perspectiva antropológica, la problemática de las políticas de lectura, la industria del libro, y la inclusión digital. Particularmente se centra en el libro digital o e-book cómo puede ser considerado como un texto cuya diferenciación explícita con un impreso radicaría en el soporte electrónico. Sin embargo la digitalización es un proceso que no sólo afecta el producto final sino también su producción, circulación o comunicación y consumo, pues en su conformación intervienen diferentes concepciones estéticas, tecnologías, y discursos respecto a la lectura.

Palabras clave: industria del libro - e-book - estética - lecturas.

[Resúmenes en inglés y portugués en la página 31]

${ }^{(*)}$ Dra. en Antropología. Investigadora del Consejo Nacional de Investigaciones Científicas y Técnicas (CONICET). Centro de Estudios Interdisciplinarios en Educación, Cultura y Sociedad (CEIECS), Universidad Nacional de San Martín (UNSAM). Docente de la Maestría en Gestión Educativa (UNSAM) y del Doctorado en Diseño de la Universidad de Palermo.

\section{Introducción}

Los libros electrónicos o digitales, conocidos comúnmente como e-books (en la terminología anglosajona $)^{1}$, tienen una presencia cada vez mayor en las ofertas de las editoriales y en las ferias de libros de distinto tipo (abiertas al público tanto como las de comercialización de derechos de autor), y en blogs y páginas web. Éstos han significado una de las mayores transformaciones en el mercado editorial de los últimos años, implicando el desarrollo y uso de tecnologías de la información y la comunicación (TIC) y soportes materiales adecuados para su consumo. De hecho, en la actualidad en las páginas de distintos organismos oficiales (ministerios y secretarías de cultura y educación, observatorios de industrias culturales, universidades y centros de investigación, organismos internacionales, entre otros) tienden cada vez más a mostrar a través de relevamientos, encuestas, estudios y análisis la incidencia de los consumos culturales digitales en distintos conjuntos sociales, a partir de diferentes producciones culturales y medios de comercialización, incluidos los digitales. 
En este contexto, la construcción estética es ejercida en relación a los contenidos multimediales, y en particular a través de los formatos digitales, cuyos espacios, tiempos, diseños y puestas a través de las pantallas redefinen las representaciones simbólicas, las experiencias y las prácticas culturales. Estética y antropología nacen casi simultáneamente a partir del estudio de la alteridad, que ha caracterizado y caracteriza aún a esta disciplina, pues la estética configura significaciones sociales (García Canclini 2008a). Tal, y como ha mostrado la disciplina antropológica, los criterios estéticos para definir aquello que era considerado bello, apreciable y de excelencia se han centrado en gran medida en parámetros de las sociedades occidentales (Spadafora y Morano 2008). Esto, en gran medida, ha dado lugar a concepciones restringidas de cultura, centradas acerca de la "alta" cultura ligada a la excelencia artística -en las bellas artes, ópera y las letras-y "baja" cultura -que involucraba aquello que quedaba por fuera de ese recorte-, y de lo que se planteaba con estética. De la mano de las complejizaciones y ampliaciones del concepto de cultura, también se ha cuestionado una única mirada estética por sobre otras. De este modo, desde la perspectiva antropológica se considera que los bienes simbólicos, en este caso libros, vehiculizan en tanto producciones culturales, sentidos y significaciones construidos socialmente.

Si bien el propósito de este artículo no es dar cuenta de las vinculaciones entre libros y TIC a través de la estética en sí, el hecho de que detrás de toda producción cultural hay una mirada estética construida socioculturalmente, llevó a pensar que incluirla en este análisis podría aportar elementos para la comprensión del fenómeno de la relevancia de los libros digitales en la actualidad. En estas páginas se procura reflexionar acerca de esto en vinculación con la industria del libro $^{2}$, a partir de la consideración de los e-book y las redefiniciones estéticas que suponen a la hora de situarse en relación con otros soportes materiales y tecnologías para favorecer la lectura.

\section{Libros y mundo digital}

La elección cada vez mayor de consumos culturales digitales, preocupa a la industria del libro porque en cierta medida estaría indicando el corrimiento de lugar de la lectura como uno de los elementos simbólicos fundamentales hacia otros más relacionados con las TIC. Esto, resulta una preocupación para actores y estudiosos del campo editorial, pues se considera una tendencia que afecta tanto de los sectores más desfavorecidos como de los sectores con altos niveles de instrucción (Argüelles 2003; Chartier en Brito y Finocchio 2009; Escalante Gonzalbo 2007, entre otros), lo cual, a su vez, se concibe como una de las principales expresiones de la "crisis" actual de la lectura. Esta crisis, en términos generales, tuvo y continúa teniendo significaciones diversas de acuerdo a los contextos en las que fue pensada y a la cual refería. Tomando en sus estudios como ejemplo la sociedad francesa, Chartier y Hèbrard (2002) plantean que entender la lectura desde la perspectiva de la crisis, implica plantear que ésta tuvo diferentes significaciones, pues si en un primer momento lo fue en concordancia con la escuela en relación a los medios masivos de comunicación como la TV (en los años '60 y '70); luego esta crisis estuvo aparejada a las condiciones socioeconómicos de la población, lo cual puso en evidencia que amplios sectores de desocupados eran iletrados (en los '70 y '80). En cambio, en la actualidad la 
crisis de lectura tiene como contracara el avance de las TIC y estaría afectando también a quiénes tienen estudios educativos de nivel superior (empresarios, dirigentes políticos) pues: “... no son para nada "lectores” en el sentido tradicional del término. Ellos saben leer y escribir muy bien ya que trabajan durante toda la jornada con pantallas..."” (Chartier en Brito y Finocchio, 2009, p. 32-33), realizando una lectura centrada prioritariamente en el entrenamiento.

El discurso de la crisis de lectura, pone justamente en evidencia que la conjunción de lectura-escritura cobró su encarnación a través del libro como soporte y herramienta prioritaria. Entonces, la desaparición o no del libro, como el que conocemos en papel y tinta, ha sido y continúa siendo un debate que lejos de agotarse sigue generando opiniones diversas, por ser durante un período prolongado de tiempo el objeto por excelencia ${ }^{3}$ de la cultura escrita. En efecto, el libro es una de las formas de acumulación y almacenamiento de la información colectiva, pues "somos incapaces de almacenar dentro del cráneo toda la información, narrativas y sensaciones poéticas de la sociedad” (Bartra, 2009, p. 165), junto con museos, archivos documentales, mapas, monumentos, fotografías, entre otras. Ahora bien, la incidencia de la digitalización está transformando esos modos de almacenamiento, pero también de preservación de la información, lo cual reestructura y resignifican también instituciones como las bibliotecas (Mihal 2009) dado que éstas pasan a estar constituidas por bienes patrimoniales que incluyen textos digitalizados, como servicios relacionados con las TIC. Asimismo, la articulación de estas distintas formas de producción, circulación y apropiación de estos textos escritos (Chartier 2007) ${ }^{4}$ muestra que la coexistencia es quizás más segura que el desplazamiento de los libros en papel por los libros en dispositivos electrónicos de distinto tipo pues los pergaminos coexisten con los libros, a la par que las tecnologías cambian constantemente de formato y se vuelven obsoletas. Por ejemplo el disco blando fue reemplazado por otro, luego el CD comenzó a ser desplazado por la memoria USB; con lo cual cambian los formatos tecnológicos más rápidamente que la lectura en papel (Eco 2012). Pero además los textos necesitan estar disponibles en formatos que les permitan ser leídos en diferentes dispositivos electrónicos -hasta ahora los más utilizados son los e-readers, tablets, computadoras de escritorios, netbooks, y teléfonos móviles-, que pueden tener distintas funciones o inclusive ser utilizados para finalidades y necesidades diferenciadas, inclusive en algunos casos requieren la conectividad simultánea en internet cuando las lecturas son de carácter on-line.

En esa convivencia entre la impresión y lo digital, es preciso distinguir además a la distinción de este último con lo digitalizado. Como es sabido, la distinción entre lo digitalizado y lo digital, radica principalmente como sostiene Doueihi (2010) en si lo digitalizado fue concebido y construido a partir de la materialidad de la cultura impresa, o si son "objetos que se transforman realmente en otra cosa cuando se los transfiere al entorno digital..." (Doueihi, 2010, p. 192), y por ende se constituyen como digitales.

Es suma, la coexistencia entre los digital y lo impreso se ha acentuado en los últimos años, los formatos impresos coexisten con otros cuyos soportes cambian, como lo son los textos digitalizados, y los e-books. Pero, sobre todo, la digitalización transforma a los libros como producciones, como sostiene Kaufman (2007) actualmente las condiciones de producción, reproducción y edición de los libros son digitales, es en el nivel de la circulación donde los textos mayoritariamente continúan utilizando el papel como principal 
recurso. Aunque como destaca Rivero (2013), las editoriales requieren también de una plataforma digital para su oferta, venta y promoción. En efecto, Gómez Escalonilla (2004) plantea que cambia el soporte de los libros con la incorporación de productos multimedia y la utilización de la red tanto para la producción, comercialización y distribución de los e-books, como para "escaparate de la producción editorial convencional" (Gómez Escalonilla, 2004, p. 54) de libros en papel. De hecho, el Centro Regional para el Fomento del Libro en América Latina y Caribe (CERLALC), uno de los organismos internacionales con mayor incidencia en el ámbito del fomento de políticas ligadas al libro y la lectura en distintos países incluidos el nuestro ${ }^{5}$, ha planteado en un documento titulado Hacia un manifiesto sobre el libro electrónico. Producción y Circulación del Libro (2014), que aunque los mecanismos de producción y circulación tradicionales de libro sigan predominando, es necesario fortalecer políticas orientadas al libro y la lectura que preparan a los países "para un escenario de predominio de las tecnologías digitales", de modo tal de identificar, entre otras cuestiones, las necesidades de distintos actores, la creación y reorientación de las instituciones y, repensar las normativas (principalmente de los derechos de autor) vinculadas con el sector editorial.

Por último, teniendo en cuenta estas consideraciones es preciso subrayar que sumado al discurso sobre la crisis de la lectura y a las nuevas formas de edición digital, otra persistencia que es la de la discusión de si los e-books puedan ser entendidos o no como libros, por sus características y formatos. Al respecto Rivero (2013) plantea que no constituyen un libro sino una unidad de comercialización de obras (sean éstas intelectuales, artísticas, y/o científicas), “...pero de ninguna manera transporta todos los sentidos, valores y usos del libro tal como lo conocemos" (Rivero, 2013, p. 95). En esta clave se obtura la posibilidad de pensar los consumos culturales digitales vinculados a la lectura, porque se soslaya las transformaciones de las prácticas culturales, las elecciones y disposiciones generales respecto al mundo digital. Pero, sobre todo, se soslaya un aspecto fundamental del libro, que es el que es también un soporte de contenidos, como sostiene Esteves (2014), es decir, la transformación, reemplazo, convivencia de un soporte por otros no es lo prioritario. Si bien puede entenderse que los libros digitales pueden no tener o transportar todos las significaciones de un libro impreso, lo cierto es que en tanto elemento simbólico es portador de sentidos y resignificaciones de la lectura, que nos llevan a considerar su dimensión estética, a la vez que a pensar las redefiniciones de los lectores.

\section{Estéticas, lecturas y libros digitales}

"Además, hay una gran diferencia entre la experiencia de sostener y hojear un libro leído hace años, descubrir los pasajes subrayados y las notas que uno anotó en los márgenes - una experiencia que transporta al lector y le permite revivir viejas emociones- y la de leer la misma obra en la pantalla de una computadora, en tipo Times New Roman de 12 puntos" (Eco, Diario El Espectador, 08/04/2012). 
La variedad de dispositivos y su continua transformación y reemplazo, tanto como el estar online, expone y enfrenta a la experiencia de leer con el atravesamiento de las TIC, en tanto ya no permite experimentar texturas, olores, gramajes, sentidos específicos de la lectura en impresa. En este sentido, las relaciones con respecto a los libros impresos continúan presentes, el contacto directo con dicho objeto, experimentado a través del tacto, olor, y experimentación mediante los distintos gramajes e ilustraciones -como se observa en el párrafo citado- van dando lugar también a otras experimentaciones. De hecho, como señala Hutnik (2011) el aspecto estético de los libros digitales, esa imposibilidad de abordar texturas por ejemplo, puede ser considerado como una desventaja en relación con los soportes de papel.

Sin embargo esta desventaja, a su vez, es generadora de otras significaciones, en tanto la experiencia estética, lo que se encuentran son distintas formas de experimentar y comunicarse con los bienes simbólicos. Estas últimas se dan de la mano de las transformaciones de distinto orden en relación a los libros, respecto a la propia industria editorial, en cuanto a los consumos culturales digitales, y en concordancia con los propios objetos a través de lecturas en pantallas a través de la diversificación de textos disponibles, tanto de libros digitalizados y, particularmente de los e-books.

$\mathrm{Al}$ respecto, Chartier (en González et. al. 2007) sostiene que en éstos las operaciones intelectuales y categorías estéticas son distintas a las que suponen los libros impresos porque implican otra inscripción en relación con los textos, y otras formas de aproximación a ellos. Pues según su perspectiva, los lectores se encuentran con los textos inscriptos en objetos, en materialidades concretas que guían o imponen, de cierta manera, la producción de sentido. Los modos de leer y los soportes que le dan materialidad se transforman en el transcurso del tiempo, tanto como las formas de entender a la lectura, sin esas transfiguraciones esta última consistiría solamente en una abstracción (Chartier 2003,1993, 1991). Así puede decirse que el concepto de lectura es dinámico y variable, no opera teniendo en cuenta las mismas dimensiones en todos los tiempos.

Ahora bien, si se transforman las formas de leer en relación a los cambios que se dan en las formas en que éstos se presenten, también cambian las valorizaciones y apreciaciones estéticas asociadas a ellos. En efecto, para quienes fueron socializados a través de la oralidad y la escritura, el libro impreso fue el eje de organización sociocultural en la conformación de los Estados modernos como vía privilegiada para el acceso y formación educativa y cultural. Dicha propuesta formativa en lectura (y escritura) se daba de la mano de instituciones centrales como eran la escuela y las bibliotecas en los consumos culturales (Pietro 2006; Gutiérrez y Romero 2007; Sarlo 1998) y principales referentes en el fomento de la lectura ${ }^{6}$. Por medio de ellas se apuntaba a unificar y homogeneizar a la ciudadanía constituida por identidades diversas e incluso antagónicas (Miller y Yúdice 2004), lo cual se asociaba a la necesidad de regular el comportamiento de los sujetos incorporándolos a la alfabetización, procurando desterrar los saberes heredados de la oralidad ${ }^{7}$, que eran considerados negativos, y promoviendo la cultura letrada.

En este sentido la escuela actuó como una "máquina estetizante", según Pineau (2013) para unificar las prácticas, costumbres y valores de esa ciudadanía que se pretendía homogeneizar, en la que la formación de lectores a través de libros y otras publicaciones impresas (Sarlo 1994) era el elemento simbólico distintivo y principal. A este papel en 
formación de las valorizaciones y apreciaciones estéticas se sumaron otros ámbitos -bibliotecas, museos, entre otros- que cumplieron también su papel en priorizar ciertos sentidos y, a la vez, invisibilizar otros, si justamente éstos no se adecuaban a los parámetros hegemónicos de la estética. En este sentido, no sólo la forma y función de los libros se vinculan con los modelos que cada época enfatiza, socializa y transmite a través de los aparatos institucionales, sino también su estatus simbólico, y como afirma Leyva (2005) éstos generan y modelan prácticas y representacionales sociales respecto a su producción, comunicación y consumos.

No obstante en el presente, la organización sociocultural involucra al desarrollo mediático a través de la conjunción de la lectoescritura con lo audiovisual, lo oral y también lo digital, generándose a partir de la digitalización no sólo el intercambio de libros y otros textos sino también la posibilidad de crear formatos y contenidos (García Canclini 2007, 2008b). Es en esa vinculación donde se redefinen los sentidos estéticos y políticos, las sensibilidades a través de un nuevo tipo de experiencia cultural que genera, a su vez, mayores interacciones entre escritores y lectores, creadores y espectadores, como señala Barbero (2008). Entonces, en la actualidad la construcción de juicios de valor, sensibilidades estéticas son también parte de un proceso dinámico, y si ya la lectura implica otras materialidades y soportes además del papel, es en esa interrelación que los e-books como formato de libro y otras lecturas en pantallas de distintos dispositivos electrónicos, se vayan configurando con mayor presencia en los consumos culturales. De hecho, "el poder de la forma digital de inscripción y transmisión es sin par en la historia de la humanidad. Es lo que la hace fascinante e inquietante..." (Chartier en Swinburn, 2009, s/r). En suma, la inscripción de los textos no se da en un vacío, sino a partir y con las experiencias de lectura que involucran distintos modos de leer, conviviendo en muchos casos la lectura en papel con lo digital. De hecho, en esa combinación también entran a jugar imágenes, inclusive como plantea García Canclini (2008b) se puede ser lector, espectador e internauta a la vez, siendo esa imbricación otra forma de leer distinta a la lectura en papel a través de las lecturas en pantallas. Desde hace ya algunos años viene enfatizándose los usos diferenciales que "nativos digitales" e "inmigrantes digitales" (Prensky 2001) ${ }^{8}$ hacen de las TIC, tanto como de las lecturas y escrituras en pantallas. Básicamente los nativos digitales son niños, jóvenes y adultos jóvenes que han nacido bajo el abrigo de las tecnologías de la información y la comunicación, mientras que los inmigrantes digitales vieron llegar la instalación de éstas en la sociedad. Si bien existen desigualdades y brechas de otro tipo, esos nativos leen y escriben (Ferreyra 2009), aunque dichas prácticas se realizan online. Al respecto Albarello (2011) sostiene que muchas veces un mismo lector complementa libros impresos y lecturas en pantallas, como cuando un texto se lee superficialmente en pantalla y luego se lo imprime para ser leído más detenidamente. Asimismo plantea que las estrategias de lectura en pantallas no son tan novedosas, ya que algunas de ellas son heredadas de la lectura en papel, sin embargo los "nativos digitales" las realizan más frecuentemente en la interacción de la lectura/navegación.

Estas cuestiones que se plantean respecto a las lecturas en pantallas posibilitan pensar la lectura a través de los e-books, puesto que si bien éstos son dispositivos específicamente originados para ser leídos electrónicamente en primer lugar, favorecen la lectura de niños y jóvenes que nacieron con las TIC ya instaladas en un entorno más próximo que los in- 
migrantes digitales. Pero también porque aún para aquellos no socializados con las TIC, la lectura de estos libros digitales puede ser una vía elegida para dicha práctica. Al respecto, Hutnik (2011) plantea que los dispositivos de lectura (independientemente de que sean Kindle, Reader, Ipad, etc.) se destinan principalmente a los “...migrantes digitales, ya que intentan copiar la experiencia lectora de un libro físico mediante el uso de la e-ink o tinta electrónica" (Hutnik, 2011, p. 320). Quizás la riqueza del formato radique en los usos potenciales que pueden llegar a tener en el entrecruzamiento de las formas de leer, algunas más relacionadas con el impreso, otras surgidas de las condiciones y transformaciones generadas a partir de este tipo concreto de materialidad, y/o de libros digitalizados.

De hecho, Igarza (2011) sostiene que el "enriquecimiento de los contenidos y puesta en común de la experiencia de los lectores son dos factores clave de éxito en el devenir de la lectura digital" (Igarza, 2011, p. 86). En la coexistencia de los e-books con otras tecnologías, se generan y configuran nuevas relaciones estéticas que atraviesan la lectura. De este modo, si la dimensión estética implica una mirada subjetiva, cargada de juicios, supuestos y valoraciones, producto de un proceso social continuamente cambiante, en el que la lectura en $e$-books, son generadoras de sensaciones y nuevas experiencias.

\section{Reflexiones finales}

En este artículo, la discusión se ha concentrado en las redefiniciones y nuevas valorizaciones estéticas que traen aparejadas las TIC en relación con la lectura, teniendo como eje de análisis el caso de los e-books. En este sentido se han abordado algunas especificaciones conceptuales respecto de los e-books que han apuntado a esclarecer tanto algunos aspectos que los diferencian de textos digitalizados como otros aspectos que los vinculan con los libros impresos.

Sin embargo, lo que está atravesando esas consideraciones es la categoría misma de lectura, que aunque no ha sido objeto de este trabajo presentar una profundización acerca de la misma, ha estado como marco articulador desde el cual pensar los e-books de la mano de las configuraciones estéticas. De tal modo, el concepto de lectura como parte de una construcción social dinámica sigue siendo clave para conocer y reflexionar acerca de las transformaciones de los libros en papel como objetos y soportes impresos; tanto como respecto de ciertos cambios y modalidades de lectura. Así como también de la mano de estas transformaciones en las formas de entender la lectura, surge que la categoría "lectores" si ya resultaba incómoda para definir a quiénes leen o escogen entre sus consumos culturales leer -discusión que se escapa a los objetivos de este trabajo, pero de la cual dan larga cuenta los estudios en antropología y sociología de la lectura-, lo es aún más sobre todo teniendo estas combinaciones que planteaba García Canclini (2008) de lectores, espectadores e internautas, o los lectores/navegadores de pantallas de los que daba cuenta Albarello (2011).

Como se ha intentado mostrar, las articulaciones entre las prácticas y sentidos respecto a lo digital y lo digitalizado, implican que aunque lo importante son los contenidos que hacen que los e-books sean considerados libros, ampliar la mirada sobre las modalidades de lectura posibilita vincularla con los soportes y materialidades en las que éstas se asientan. Por 
ello, aunque aún su uso no es mayormente generalizado en los consumos culturales digitales, en relación con otros dispositivos electrónicos como el teléfono celular por ejemplo, es posible avanzar en el análisis de los e-books, puesto que éstos en tanto tales constituyen un producto cultural específico de la industria del libro, son generados a través de procesos creativos que se redefinen constantemente en el marco de la sociedad actual.

A su vez, atravesados por las transformaciones que se apuntaron con respecto a los e-books también se reconfiguran no sólo la mirada estética a través de la perspectiva de quién lee y/o sus manera del leer sino también la propuesta estética. Es decir, están cambiando las aproximaciones hacia esos e-books, tanto como las propuestas del libro como producto y sus particularidades. La portabilidad, su capacidad de almacenaje, entre otras características de los e-books hace que éstos sean plausibles de ser investigados, dado lo reciente del proceso, atendiendo a que pueden llegar a marcar en esta transformación del papel a lo digital en palabras de Maquet (1999) un nuevo "locus estético", que si bien aún no puede ser claramente identificable si está marcando la construcción de ciertas tendencias y puede ser objeto de futuros análisis.

\section{Notas}

1. En la terminología anglosajona se distingue a los e-books de los dispositivos de lectura (eReader), en cambio en castellano contenido y dispositivo no se diferencian (Merino 2015). 2. La industria del libro forma parte de la "industria editorial", para una conceptualización y desarrollo de la misma en nuestro país véase Getino (2008); Puente (2007).

3. Aunque no el único pues en las sociedades presentes existen también otras formas de cultura escrita como la escritura a mano que implica una forma distinta de leer (Chartier en González, Tatián, López, Scolnik 2007), tanto como otras tales como la oralidad y la lectura de imágenes por ejemplo.

4. En este artículo se utiliza indistintamente el vocablo texto escrito como sinónimo de libro para no ser reiterativos en la lectura, pero Chartier realiza distinciones respecto a uno y a otro término que pueden consultarse en el artículo citado (Chartier en González et.al. 2007), como en otros trabajos del autor.

5. Para mayores referencias sobre este organismo véase Mihal (2012), donde se explica algunos hitos clave en los cuales el CERLALC tuvo un rol destacado en los procesos de conformación de políticas del libro y la lectura en distintos países iberoamericanos tanto como en la creación y/o reorientación de leyes que posibilitaran su institucionalización.

6. Vale la pena recordar que las bibliotecas en Argentina tuvieron tanto como el sistema educativo un rol protagónico en la instauración de la relación lectura y ciudadanía, la cual fue -desde fines del siglo XIX y principios del XX-con la Ley de Educación № 1420 (1882) y con la Ley de Bibliotecas Populares $\mathrm{N}^{\circ} 419$ (1870) una de las prerrogativa para instalar una sociedad instruida y lectora.

7. En efecto, Prieto destaca que se constituyó un nuevo público asociado a la lectura en Argentina, “..., el nuevo lector tendió a delimitar un espacio de cultura específica en el que el modelo tradicional de la cultura letrada continuó jugando un papel predominante aunque ya no exclusivo ni excluyente" (Prieto, 2006, p. 13). 
8. Esta distinción entre digital natives y digital inmigrants fue presentada por Marc Prensky (2001), generando controversias que no pueden negar que existen brechas generacionales, entre otro tipo de brecas, como sostiene Piscitelli (2006) que dificultan la apropiación y uso de las TIC en general, y aunque actualmente ha sido complejizada porque homogeneiza en el sentido de que los “...jóvenes tienen prácticas y competencias tecnológicas muy disímiles según sea su marco de experiencias (fuertemente vinculado a su nivel socioeconómico y a su capital cultural)" (Dussel y Quevedo, 2010, p. 12) continua presente inclusive para pensar cuestiones referidas al libro digital.

\section{Referencias bibliográficas}

Albarello, F. (2011). Leer-navegar en internet: las formas de lectura en la computadora. Buenos Aires: La Crujía.

Argüelles, J. D. (2003) ¿Quéleen los que no leen? El poder inmaterial de la literatura, tradición literaria y el hábito de leer. México: Paidós Ed.

Barbero, J. (2008). De la ciudad letrada a la creatividad ciudadana. Prefacio. En Taylor, C. y Pitman, T. (eds) Latin American Cyberculture and Cyberliterature, pp. 1-7. Chicago: University Chicago Press.

Bartra, R. (2009). El futuro papel del papel. En Congreso Internacional del Mundo del Libro: Memoria (pp. 165-169). Ciudad de México: Fondo de Cultura Económica.

Brito, A. y Finocchio, S. (2009). (Enseñar a) leer y escribir, en presente y a futuro. Entrevista a Anne Marie Chartier. Revista Propuesta Educativa, noviembre, 32, pp. 65-71.

Chartier, R. (2009). La biblioteca entre herencia y futuro. En Ramírez Leyva, E. (coord.) La biblioteca pública y la formación de lectores en la sociedad de la información: Memoria (pp. 21-31). México: CONACULTA - UNAM.

. (2003). Cultura escrita, literatura e historia. México: Fondo de Cultura Económica.

(1993). Libros, lecturas y lectores en la edad moderna. Barcelona: Alianza Editorial.

Chartier, A. M. y Hébrard, J. (2002). La lectura de un siglo a otro. Discursos sobre la lectura (1980-2000). Barcelona: Gedisa Editorial.

Doueihi, M. (2010). La gran conversión digital. Buenos Aires: Fondo de Cultura Económica.

Dussel, I. y Quevedo, L. (2010). “Educación y nuevas tecnologías: los desafíos pedagógicos ante el mundo digital. Documento básico”. VI Foro Latinoamericano de Educación y Nuevas Tecnologías: Los Desafíos Pedagógicos Ante El Mundo Digital. Buenos Aires: Ed. Santillana. Disponible en http://virtualeduca.org/ifd/pdf/ines-dussel.pdf

Escalante Gonzalbo, F. (2007). A la sombra de los libros: lectura, mercado y vida pública. México: El Colegio de México.

Ferreiro, E. (2009). La alfabetización y el mundo digital. En Congreso Internacional del Mundo del Libro: Memoria (pp. 91-102). Ciudad de México: Fondo de Cultura Económica.

García Canclini, N. (2008a). "Geopolítica y estéticas interculturales". Conferencia dictada en Universidad de Miami. Disponible en http://www.nestorgarciacanclini.net/index. php/estetica-y-antropologia/78-conferencia-qgeopolitica-y-esteticas-interculturalesq . (2008b). Lectores, espectadores e internautas. Barcelona: Gedisa Editorial. 
. (2007). Cultura, organización social y ampliación de ciudadanía. En Una lectura del país que queremos, una red ciudadana para construirlo: Encuentro Nacional de Bibliotecas Populares 2007, pp. 33-42. Buenos Aires: CONABIP.

Getino, O. (2008). El capital de la cultura. Las industrias culturales en la Argentina. Buenos Aires: Ed. Ciccus.

Gómez-Escalonilla, G. (2004). La edición de libros: un sector potente a la defensiva digital. En Bustamante, E. (coord.) Comunicación y cultura en la era digital. Industrias, mercados $y$ diversidad en España (pp. 37-65). Barcelona: Gedisa.

González, H., Tatián, D., López, M., Scolnik, S. (2007). Conversaciones con Roger Chartier: Hay una tendencia a transformar todos los textos en "banco de datos". Lectura y Tecnología, La Biblioteca Revista, primavera, 6, pp. 10-28.

Esteves, F. (2014). Manual de supervivencia para editores del siglo XXI. Buenos Aires: Eudeba.

Gutiérrez, L. y Romero, L. (2007). Sectores populares, cultura y política: Buenos Aires en la entreguerra. Buenos Aires: Siglo XXI Editores.

Hutnik, E. (2011). “¿Han revolucionado los libros electrónicos a la industria editorial?”. Ponencia presentada en las X Jornadas Nacionales de Literatura Comparada. Facultad de Humanidades y Ciencias de la Educación. Universidad Nacional de La Plata.

Igarza, R. (2011). "El libro-pantalla: los contenidos digitales y el futuro de la lectura". En Artopoulos, A. (coord.) La sociedad de las cuatro pantallas. Una mirada latinoamericana, pp. 81-102. Madrid: Fundación Telefónica, Editorial Ariel.

Kaufman, A. (2007). “Imaginarios, lecturas, prácticas”. Lectura y Tecnología, La Biblioteca Revista, primavera, 6, pp. 76-83.

Leyva, E. (2005). La lectura en los tiempos de internet. En Leyva, E. (comp.) Lectura: pasado, presente y futuro. Memoria del Seminario Lectura: pasado, presente y futuro, pp. 98-114. México: UNAM.

Maquet, J. (1999). La experiencia estética. Madrid: Celeste.

Merino, J. (2015). “Literatura y nuevas tecnologías". Revista Iberoamericana, XV, 57, pp. 193-205.

Mihal, I. (2012). “Cultura y Desarrollo: Planes Nacionales de Lectura en Brasil y Argentina”. Políticas Culturais em Revista, n’ 2 vol.(5), pp. 115-134.

. (2009). Acerca de los consumos culturales y las nuevas tecnologías: el caso de

las bibliotecas de la Ciudad de Buenos Aires. Ponencia presentada en el XXVII Congreso de la Asociación Latinoamericana de Sociología (ALAS). Facultad de Ciencias Sociales. Universidad de Buenos Aires. Agosto.

Miller, T., Yúdice, G. (2004). Política Cultural. Barcelona: Gedisa Editorial.

Pineau, P. (2013). La escuela como máquina estetizante. Revista Todavía, noviembre, 30. Buenos Aires: Fundación Osde. Disponible en http://www.revistatodavia.com.ar/todavia 31/30.educacionnota.html

Piscitelli, A. (2006). Nativos e inmigrantes digitales. ¿Brecha generacional, brecha cognitiva, o las dos juntas y más aún?. En Revista Mexicana de Investigación Educativa, enero-marzo, vol. 11, (28), 179-185.

Prensky, M. (2001). Digital natives, digital inmigrants. On the Horizon, (9) 5, 1-6. Disponible en http://www.marcprensky.com/writing/Prensky\%20-\%20Digital\%20Natives, \%20 Digital\%20Immigrants\%20-\%20Part1.pdf 
Prieto, A. (2006). El discurso criollista en la formación de la Argentina moderna. Buenos Aires: Siglo XXI Editores.

Puente, S. (2007). Industrias Culturales. Buenos Aires: Prometeo.

Rivero, N. (2013). "La literatura en su época de reproductibilidad digital". Cuadernos del Centro de Estudios en Diseño y Comunicación (Ensayos), septiembre, año 14, 45, pp. 91-101. Sarlo, B. (1998). La máquina cultural. Buenos Aires: Editorial Ariel. . (1994). Escenas de la vida posmoderna. Buenos Aires: Editorial Ariel.

Spadafora, A.y Morano, L. (2008), "La cultura en disputa: pintura figurativa e identidad étnica entre los ishir (Alto Paraguay)". JournalTipiti. SocietyfortheAnthropology of Lowland South America. Cambridge.

Swinburn, D. (2009). "El poder de la lectura digital no tiene parangón en la historia". Entrevista al historiador Roger Chartier. Disponible en http://www.nacionapache.com.ar/ archives/2451

\begin{abstract}
This article is part of a line of work that addresses, from an anthropological perspective, the problem of policies reading the book industry, and digital inclusion. Particularly focusing on the digital book or e-book how it can be considered a text whose explicit differentiation with a printed lie in the electronic media. However, digitization is a process that not only affects the final product but also its production, circulation and consumption or communication, as in conformation different aesthetic conceptions involved, technologies, and speeches about Reading.
\end{abstract}

Key words: book industry - e-book - aesthetic - reading.

Resumo: Este artigo é parte de uma linha de trabalho que aborda, a partir de uma perspectiva antropológica, o problema da política de leitura, a indústria do livro, e da inclusão digital. Particularmente com foco no livro digital ou e-book e como ele pode ser considerado um texto cuja diferenciação explícita com um impresso estaria na mídia eletrônica. Mas a digitalização é um processo que afeta não só o produto final, mas também a produção, circulação e consumo ou comunicação, como na conformação diferentes concepções estéticas envolvidas, tecnologias e discursos sobre a leitura.

Palavras chave: indústria do livro - e-book - estética - leituras. 

Fecha de recepción: marzo 2017

Fecha de aceptación: octubre 2017

Versión final: marzo 2019

\section{Desafíos actuales de las políticas culturales. Análisis de caso en el Municipio de Avellaneda \\ Laura Ferreño* y María Laura Giménez ${ }^{\star *}$}

Resumen: El estudio del impacto de políticas inclusivas socio-culturales de los distintos niveles de gobierno (nacional, provincial y municipal) en los barrios de Dock Sud, Isla Maciel, Villa Tranquila y Villa Corina (Partido de Avellaneda) develó tanto la ausencia de información respecto a los programas en ejecución como la carencia evaluaciones (antes, durante y post) y de articulación entre programas y equipos de trabajo gubernamentales. La investigación examinó el impacto de estas políticas y detectó las necesidades manifestadas por los vecinos en las áreas relevadas en función de su especificidad (población en riesgo debido a vivir en asentamientos radicados desde varias décadas en zonas con altos índices de contaminación ambiental, alta densidad habitantes/metro cuadrado, precariedad laboral, entre otros indicadores). El análisis de los datos proporcionó varios hallazgos, entre ellos, la brecha entre las necesidades de la población y los programas implementados, necesidades enmascaradas tanto por la limitada evaluación de estos desde la gestión pública, como por la naturalización de nociones y conceptos a partir de los cuales se diseñan y ejecutan.

El artículo analizará las tensiones entre las instituciones gubernamentales que diseñan y ejecutan estas políticas públicas y aquellos a quienes "van dirigidas".

Palabras clave: gobierno - política social - inclusión - ciudadanía - sectores vulnerables.

[Resúmenes en inglés y portugués en las páginas 48-49]

${ }^{*}$ Dra. en Antropología Social (IDAES-UNSAM). Profesora adjunta en la Universidad Nacional de Avellaneda (UNDAV) y Coordinadora del Observatorio de Ciudadanía Cultural (UNDAV).

${ }^{(* *)}$ Dra. en Sociología (UCA). Profesora adjunta en la Universidad Nacional de Avellaneda (UNDAV) e investigadora del Observatorio de Ciudadanía Cultural (UNDAV).

\section{La política pública en clave ciudadana}

El estudio de las políticas culturales supone recorrer el camino que se inicia en la etapa del diseño y continúa durante su implementación. Las instituciones públicas deberían acompañar cada uno de los momentos de este proceso a través de evaluaciones propias 
realizadas por expertos, pero ello solo es habitual cuando los programas cuentan con financiamiento externo, escenario poco frecuente en esta área. Quizás por este motivo la mayoría de los trabajos se detienen en el análisis de las dos primeras instancias; son menos frecuentes, en cambio, aquellos que analizan la evaluación de cada una de las fases que implican la ejecución de estas políticas.

Sin embargo, esta situación también puede hacerse extensiva a los programas que involucran el conjunto de las políticas sociales a pesar que estos programas suelen contar subsidios de organismos internacionales. No es ajeno a esta situación el recambio cíclico en cada área gobierno cada vez que se designa una nueva autoridad. La mayoría de las veces los programas se dan de baja abruptamente sin realizar las evaluaciones correspondientes. Durante el relevamiento bibliográfico que acompaña a esta investigación y en el transcurso del trabajo territorial, no pudimos hallar referencias a evaluaciones efectuadas por parte de los responsables o de las áreas correspondientes (ni antes, ni en el transcurso, ni al concluir programas dirigidos a grupos vulnerables). Nos pareció primordial entonces explorar qué mecanismos se implementaban para validar los programas y el conocimiento de las acciones que cada gobierno interviniente implementaba contemporáneamente en zonas vulnerables. En tal sentido, las áreas de los diversos niveles de gobierno (nacional, provincial y local) se deben un debate que involucre las propuestas culturales dentro del marco más amplio de ámbitos institucionales a cargo de los proyectos de inclusión que dependen de otras dependencias gubernamentales. Ello supone el trabajo conjunto de áreas administrativamente autónomas (Cultura, Desarrollo Social, Educación, Derechos Humanos, entre otras) en el organigrama estatal.

Esta discusión no debe soslayar la necesidad de estudiar propuestas concretas formuladas específicamente para sectores vulnerables. Durante la observación en estos barrios, comprobamos que estos grupos acuciados por las urgencias económicas, a diferencia de los sectores de poder adquisitivo más alto, tienden a interesarse en aquellas actividades que presuponen les permitirán adquirir nuevas habilidades y mejorar sus escuálidos ingresos hogareños. Estas personas adultas, económicamente activas, aun cuando cuenten con actividades "culturales" en su barrio tenderán a solicitar talleres que les brinden salida laboral.

Es interesante preguntarse, en consecuencia, si las propias políticas no reproducen aquellas situaciones de exclusión que pretenden eliminar. Como Vich (2014), se partió de la premisa de que al diseñar políticas culturales se debe tener en cuenta que el acceso a los bienes culturales es fragmentario, y por lo tanto, es necesaria la generación de propuestas que contemplen la situación socio-económica y la inserción dentro del tejido territorial de los potenciales destinatarios. La claridad de esta meta es central, ya que si estas premisas no se cumplen, la brecha en la desigualdad respecto al acceso a los bienes culturales seguirá reproduciendo un intercambio de bienes simbólicos centrado casi únicamente entre personas que se perciben a sí mismas como parte de un mismo "universo cultural". El desafío es entonces dilucidar cómo vincular a ciudadanos que identitariamente se presuponen excluyentes por su condición social, por la comunidad donde viven o por las redes que integran (de estudio, trabajo, parentesco, amistad o barrial, entre otras).

A partir de estas consideraciones, en esta investigación, se buscó dar una respuesta exploratoria y parcial- a estos interrogantes a través del análisis de estudios de caso de 
programas sociales en Argentina. Esta instancia, aunque fructífera, no aportó información en función de los objetivos propuestos para el proyecto. Cabe destacar, no obstante, que algunas de estas lecturas ayudaron a analizar posibles respuestas a los desafíos que surgían. En ese sentido, la interesante compilación de Guillermo Cruces, Juan Martín Moreno, Dena Ringold y Rafael Rofman (2008), está planteada como una propuesta interdisciplinaria de interpretación de algunos de los aspectos que determinan el éxito o el fracaso de las políticas públicas en el área social. Entre ellas, los autores mencionan las diversas formas que asume la interrelación entre los diferentes niveles de gobierno que intervienen en la problemática (nación, provincias y municipios), las caracterizaciones y las diferentes conceptualizaciones de las políticas sociales (que pueden conducir a la estigmatización de acuerdo a las formas que adopten su implementación) y las percepciones de los propios beneficiarios; estas dimensiones mostraron posibles visiones a tener en cuenta para la elaboración de las entrevistas semi estructuradas y en profundidad que teníamos previsto realizar.

Laura Golbert (2004), en su estudio de la ciudad de Buenos Aires, plantea parcialmente este debate al interpelar las diversas concepciones ideológicas y/o políticas a partir de las cuales se diseñan las políticas sociales. La información que aporta su trabajo resulta reveladora: la autora no solo describe el desconocimiento del gobierno local de programas y planes ejecutados por el gobierno nacional, sino también reflexiona en torno a la "naturalización" de los funcionarios a cargo de estos programas frente a la falta de evaluación de estas políticas durante las distintas etapas de su implementación.

Por lo tanto, el perfil de quienes ocupan los cargos ejecutivos y administrativos en los organismos gubernamentales y cómo acceden a estos (Lomnitz, 2001) también explica estas tensiones técnico/burocráticas de los funcionarios públicos y la formas en que se resuelven las carencias que el propio estado no es capaz de suplir. En tal sentido, Loïc Wacquant (2013) recuerda que se debe diferenciar los conceptos nativos utilizados por las autoridades estatales, los dirigentes barriales y los propios habitantes, de los conceptos analíticos que elaboran los investigadores al abordar la compleja situación social de estas comunidades. Como bien recuerda el autor, la igualdad en el acceso a los bienes públicos concierne a "la esfera de la ciudadanía" (Wacquant, 2013, p. 325) y no se vincula con el origen étnico o religioso, entre otros, de las personas.

En consecuencia, los estudios centrados en el análisis de las concepciones subyacentes en los programas sociales, a menudo no tienen en cuenta algunos aspectos claves para comprender la situación no solo socio-económica, sino también el escaso o nulo estatus social del cual gozan estas personas. A la segregación espacial (Álvarez, 2005; Segura, 2006) que Wacquant denomina afirmación del gueto (Wacquant, 2013) se imponen como corolario fronteras simbólicas que excluyen y estigmatizan. Si se quiere aprehender estas realidades desde la praxis y no desde la teoría política, a la noción de Estado, asociado a sus capacidades tanto administrativas (Balán, 2015) como de reproducción de hegemonía (Cantamutto, 2015), debe contraponerse una perspectiva que lo aborde "desde abajo" (Abélès, 2005; Espinosa Molina, 2015), desde aquellas prácticas cotidianas que permiten interpelar y contextualizar las instituciones gubernamentales, las políticas públicas, los actores que las ejecutan y aquellos a quienes "van dirigidas".

Así como algunos estudios territoriales interpelan el rol del Estado como foco de la integración colectiva (Cantamutto, 2015), en el presente texto las políticas públicas 
se analizan no solo en función de las "propiedades" asociadas a ella (Balán, 2015), sino también respecto a la ausencia de información referida a la cantidad de programas vigentes, sus evaluaciones (antes, durante y con posterioridad a su implementación) y a la ausencia de una transversalidad que articule tanto programas como equipos de trabajo (Golbert, 2004).

Asimismo, para comprender las rutinas y acciones que explican las formas de hacer política (Rosato, 2009), se realizó un relevamiento de la bibliografía que aborda esta problemática. Fundamentalmente de ciertos textos que exploran los lazos entre política, punteros territoriales y acceso a la ayuda social. Las reflexiones en torno a nociones clásicas como patronazgo (Wolf, 1980; Boivin; 2001; Mair, 2015) y clientelismo político -este último fundamentalmente a partir de los estudios que Javier Auyero (1998, 2004, 2012) realizó en el conurbano bonaerense, particularmente en el Partido de Lanús, lindante con Avellaneda- revelaron la importancia de la observación territorial. Las formas de construcción y reproducción de las redes sociales en estas comunidades nos advirtieron respecto a la rapidez de los cambios en las interrelaciones interpersonales en estos espacios regidos por la extrema vulnerabilidad.

En tal sentido, a pesar de compartir las críticas metodológicas efectuada por Vommaro (2008), resultó significativo el aporte de una etnografía realizada en Villa Inflamable (Auyero, Javier y Swistun Débora, 2007), tanto por su cercanía geográfica con la zona de Dock Sud, Isla Maciel y Villa Tranquila, como por los problemas de contaminación que afectan a todas ellas. Otros aspectos de esta problemática, como aquellos desarrollados por Larissa Lomnitz (2001), permitieron repensar la noción clásica del clientelismo, a partir de la indagación del rol que cumplen las redes familiares, de amistad o instrumentales (Wolf, 1980) en estas comunidades, perspectiva que Auyero analiza enfatizando específicamente su aspecto clientelar. Las perspectivas de estos autores nos señalaron los caminos que se deben recorrer -y los que no- para explorar las posibilidades concretas que los vecinos tienen de apropiarse de los saberes aprehendidos en actividades realizadas a través de programas de inclusión social.

Este primer relevamiento bibliográfico permitió asimismo incorporar perspectivas metodológicas que sustentaron el énfasis central que gradualmente adquirió el abordaje cualitativo (Rivas, 2007) de la investigación en el campo, así como la definición de las dimensiones e indicadores seleccionados para la encuesta.

El reto, por lo tanto, fue direccionar más asiduamente las discusiones y las investigaciones académicas al análisis de casos concretos referidos a programas culturales; creemos que gestión y universidad no se excluyen, sino que por el contrario se precisan recíprocamente. Desde esta investigación se comenzó un estudio de campo con el propósito de transferir al Municipio una matriz que permitiera al gobierno local evaluar el impacto de programas de inclusión, para con los datos que esta arrojase poder corregir los factores que impedían su efectivo cumplimiento ${ }^{1}$.

Con el objeto de guiar la lectura, a continuación, se presenta el caso que se analiza en la investigación -el Municipio de Avellaneda-, para después avanzar en la descripción del Área de cultura del Municipio identificando en el último apartado los hallazgos encontrados en el análisis de la problemática de la institucionalidad. 


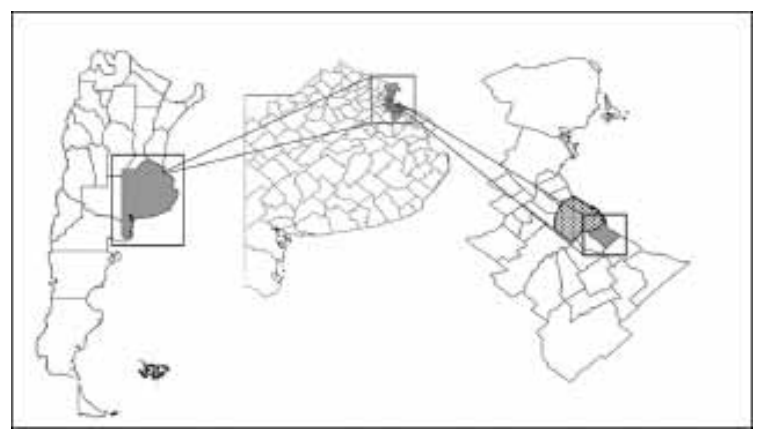

Figura 1. Ubicación geográfica del Municipio de Avellaneda en la República Argentina, en la Provincia de Buenos Aires y en el AMBA (Área Metropolitana de Buenos Aires). Mapa elaborado por Nicolás Diéguez.

\section{La institucionalidad gubernamental en la periferia del territorio municipal}

El Partido Avellaneda (Provincia de Buenos Aires), es colindante con la ciudad de Buenos Aires, de la cual la separa el Riachuelo, tristemente famoso por su contaminación ${ }^{2}$. La cercanía entre ambas es relevante debido a que Avellaneda, como su vecina Buenos Aires, se destaca desde mediados del siglo XX por la variedad de su oferta cultural. (Ver Figura 1) En marzo de 2014, con la creación de la escuela secundaria de la UNDAV en Villa Maciel, las autoras de este artículo iniciaron trabajos de exploración previas en el territorio, gracias a los cuales se detectó la carencia de información socio-cultural en la zona Dock SudTranquila-Maciel, área de influencia del establecimiento. Desde la Secretaría de Cultura y Promoción de las Artes del municipio, apareció como primera demanda el análisis de los programas implementados desde su órbita para subsanar aquellas limitaciones que la propia dinámica pública impedía resolver.

La primera aproximación a la problemática fue el análisis de las características de estas propuestas municipales: espacios donde se llevaban a cabo, grupos sociales y etarios a quienes estaban dirigidos, personas que asistían, apropiación de las propuestas por parte de éstos y un sondeo comparativo entre los resultados esperados con aquellos efectivamente alcanzados.

En una segunda etapa, el foco se localizó en el estudio de las distintas propuestas y actividades de la Secretaría en localidades y barrios vulnerables del municipio. Se inició entonces un trabajo en conjunto entre la UNDAV y la Secretaría de Cultura, Educación y Promoción de las Artes del municipio para evaluar el impacto de las políticas municipales y detectar las necesidades manifestadas por los vecinos en las áreas seleccionadas en función de su especificidad (población en riesgo debido a vivir en asentamientos radicados desde varias décadas en zonas con altos índices de contaminación ambiental, alta densidad habitantes/ metro cuadrado, precariedad laboral, entre otros indicadores). Estas zonas se caracterizan 
por la ejecución desde los distintos niveles de gobierno de proyectos destinados a mejorar las condiciones de vida de sus habitantes e incluir a estas comunidades en el tejido urbano del territorio; para ello se realizaron mejoras o entrega de nuevas viviendas, proyectos canalizadores de salidas laborales a través de la enseñanza de nuevos oficios o conformación de mini pymes, salitas sanitarias y programas educativos-culturales, entre otros.

Frente estos antecedentes y ante la falta de censos e información socio-cultural de las localidades de Avellaneda, se concluyó conjuntamente la necesidad de disponer de un instrumento que no solo relevara la información, sino que también asistiera en la medición del impacto de políticas públicas vinculadas con la inclusión social (programas educativos, culturales y sanitarios), en los barrios más pobres de la localidad.

El territorio seleccionado tiene como particularidad la presencia muy dinámica de programas de inclusión social. Como se carecía de información sobre estos, en el primer relevamiento realizado en estos barrios los encuestados enumeraron los planes y/o programas de los cuales recibían ayuda gubernamental. Focalizados en grupos vulnerables, el Estado Nacional financiaba: el Plan de Finalización de Estudios Secundarios -FinES ${ }^{3}$-, la Asignación Universal por Hijo -AUH ${ }^{4}$-, Argentina Trabaja ${ }^{5}$, Ellas Hacen ${ }^{6}$ y el Programa de Respaldo a Estudiantes de Argentina -PROG.R.ES.AR ${ }^{7}$-; la Provincia de Buenos Aires: el Plan más Vida ${ }^{8}$ y el Envión ${ }^{9}$; y el Municipio de Avellaneda: los Puntos Culturales ${ }^{10}$ (peluquería, cerámica, folclore, canto, yoga, taller de madera y vitraux), Avellaneda Recicla $^{11}$, el Polideportivo Delfo Cabrera ${ }^{12}$ y la Colonia del Polideportivo José María Gatica ubicado en el Parque de los Derechos del Trabajador, popularmente conocido como "Parque Domínico". Pese a la importante asistencia que recibían los vecinos, el gobierno local no contaba por entonces con un estudio de su impacto en la zona.

\section{El “área cultura” en el Municipio de Avellaneda}

Desde fines del siglo XIX se asentaron en el actual territorio de Avellaneda inmigrantes provenientes de distintas regiones de Europa, Medio Oriente, e incluso África (caboverdeanos). Desde mediados del siglo XX, junto con la importante oleada inmigratoria de la segunda posguerra, aparecen los migrantes del interior del país y gradualmente población procedente de los países limítrofes. Muchas de estas colectividades crearon sus propios centros culturales mientras paralelamente surgían organizaciones (de fomento, tradicionalistas, etc.) que revalorizaban las tradiciones argentinas.

A partir de 1952, al crearse la Dirección de Cultura en el área municipal, se fomentan el teatro, las actividades literarias, la enseñanza de la música, las artes plásticas y las danzas (nativas y clásicas), creándose los cuerpos estables de teatro, de baile y la orquesta sinfónica. En 1960 en una antigua casona se crea la primera Casa de la Cultura de la provincia de Buenos Aires, estratégicamente ubicada al lado de la catedral y frente a la plaza principal del partido.

Sucesivos gobiernos locales ampliaron la oferta cultural, situación que motivó la necesidad de formalizar desde una perspectiva burocrática-educativa las propuestas y actividades del área de cultura municipal. Tomaron cuerpo entonces en el transcurso de los años las escuelas artísticas: El Instituto Municipal de Educación por el Arte (IMEPA); el Instituto 
Municipal de Arte Plásticas (IMAP); el Instituto Municipal de Arte Fotográfico y Técnicas Audiovisuales (IMAFTA); el Instituto Municipal de Arte Cinematográfico (IDAC); el Instituto Municipal de Cerámica de Avellaneda (IMCA); el Instituto Municipal de Folklore y Artesanías Argentinas (IMFAA); el Instituto Municipal de Música de Avellaneda (IMMA); y el Instituto Municipal de Teatro (IMT).

El gobierno municipal a través del tiempo, se hizo cargo de asociaciones que originalmente habían sido instituidas por organizaciones de la sociedad civil (como es el caso del Teatro Roma). Asimismo, creó una gran variedad de entidades vinculadas con la cultura y/o la oferta educativa formal y no formal del área, como: la Escuela Municipal de Danzas y la Escuela de Circo, Murga y Magia Municipal; el Instituto de Investigaciones Históricas; la Comisión de Preservación del Patrimonio Histórico, Cultural, Arquitectónico y Natural; y el Instituto de Letras. Respecto a las artes musicales, para acercarlas a la ciudadanía concibió los elencos estables de la orquesta sinfónica municipal, la orquesta sinfónica juvenil, la orquesta escuela de niños y la orquesta municipal de tango. Fue además uno de los pioneros en la creación de talleres descentralizados en los distintos barrios y en la constitución del Centro de producciones artísticas y culturales de Avellaneda (PAC), que asiste a los artistas en la producción, difusión y distribución de sus obras.

En consecuencia, tanto los cursos y los talleres como los institutos cumplieron un doble rol en la agenda municipal: mediante los talleres de extensión se difundieron distintas actividades vinculadas con la cultura y el arte; y a la vez, los centros educativos formaron docentes y profesionales.

Entrevistas realizadas a autoridades, funcionarios y agentes municipales nos permitieron tomar conocimiento de los cambios que se realizaron en el área de cultura desde la década de 1990. A partir de la gestión municipal 1991-1995 y durante los períodos 1995-1999, 2004-2007 y 2007-2011, se rediseñó el Sistema de Acercamiento Cultural a los Barrios de Avellaneda (SACBA) mediante actividades destinadas a todos los grupos etarios: niños, jóvenes, adultos y tercera edad. El SACBA pretendió trabajar sobre la identidad del partido; democratizar el acceso a la cultura en sus diversas manifestaciones a través de talleres gratuitos; alcanzar un desarrollo cultural sustentable, en términos de gestión; concientizar respecto al derecho a la autonomía cultural identitaria; favorecer la inclusión; generar un diálogo entre los protagonistas del campo cultural: los artistas, el público y los gestores; y promover el desarrollo, la participación, la inclusión, el intercambio sociocultural de la comunidad y una construcción colectiva de la "cultura" (Ferreño, 2011). El SACBA se implementó en las localidades de todo el municipio a través de la articulación con las instituciones de la sociedad civil barriales.

El SACBA implicó un cambio radical en el diseño e implementación de los programas culturales, pues hasta ese momento la mayoría de la oferta se concentraba en el centro de la localidad cabecera del partido. Sin embargo, las características del SACBA no favorecieron el acceso de la población de las áreas más alejadas y vulnerables porque en estas zonas la presencia de asociaciones civiles era menor y con infraestructura muy precaria respecto a los barrios de clase media. Algunos informantes entrevistados mencionaron que para mejorar el acceso de estos grupos más desprotegidos, el SACBA se reemplazó por el Programa Punto Cultural, que ofrece actividades gratuitas de formación y recreación de manera descentralizada. 


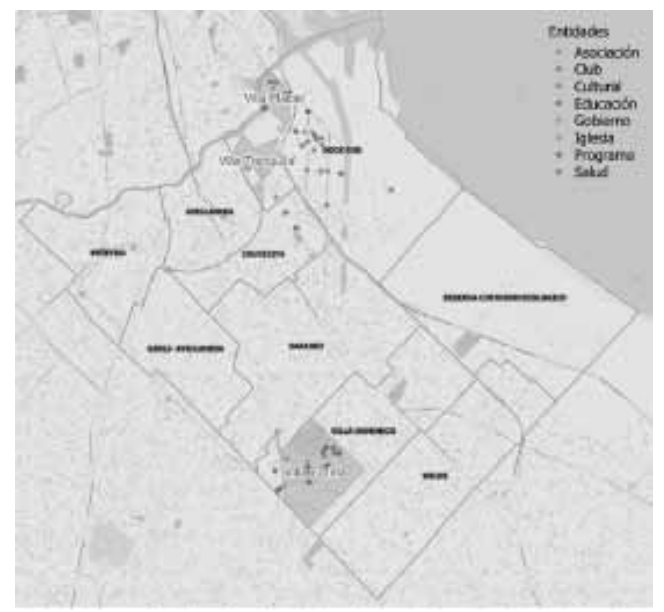

Figura 2. Ubicación de Villa Tranquila, Isla Maciel, Dock Sud y Villa Corina en el plano catastral del Municipio de Avellaneda. Mapa elaborado por Nicolás Diéguez.

De acuerdo a la información suministrada por los informantes claves, los talleres impartidos en el "Programa Municipal'Punto Cultural' nacen para brindar a los vecinos de la Ciudad diferentes oportunidades de formación y recreación de manera descentralizada, gratuita y cerca de sus casas. Niños, jóvenes y adultos pueden elegir qué hacer en su barrio, porque la oferta de talleres es amplia y variada”. De este modo, al analizar la oferta de cada uno de las 24 Puntos Culturales se puede comprobar que los talleres que se dictan varían de uno a otro.

Si bien cuenta con 16 Puntos en las distintas localidades, muchos de ellos se encuentran ubicados fundamentalmente en las zonas más humildes y/o desfavorecidas del partido, o en las cercanías de estas: el Punto Cultural de Villa Corina brinda 22 talleres y entre estos se ofrecen 3 talleres de peluquería, 2 de electricidad, 2 de gimnasia y 2 de construcción de instrumentos; el de Isla Maciel tiene solo 8 actividades pero todas vinculadas con la "cultura" (cerámica, títeres, folclore, educación musical, entre otros); en Dock Sud hay 2 Puntos Culturales, el No 13 con 10 talleres (todos "culturales") y el No 17 con 13 talleres, entre ellos 1 de huerta y otro de reciclado ; y en Villa Tranquila se dictan 15 talleres, 2 de los cuales corresponden a huerta y reciclado.

El presente trabajo se propone explorar el impacto y la apropiación ciudadana de las actividades culturales desarrolladas en las áreas de influencia de los Puntos Culturales No 2 Isla Maciel, No 3 Villa Tranquila, No 4 Dock Sud y, No 10 y No 11 Villa Corina. (Ver Figura 2) 


\section{La problemática de la institucionalidad en el territorio}

El proyecto de investigación se propuso como primera tarea el relevamiento de la totalidad de los programas nacionales, provinciales y municipales, bajo cuya órbita se ejecutaban las actividades culturales y educacionales que se habían registrado en el territorio.

La ausencia de información en los sitios web oficiales -por desidia o para favorecer los mecanismos de mediación informales- limitó desde el inicio el desarrollo de la investigación, afectando el relevamiento de los programas que actuaban en las localidades en estudio. De esta forma se careció de la nómina de programas, discriminados por organismo responsable, población objetivo, oferta, estrategia de acción, resultado esperado, período de ejecución, instituciones territoriales a las cuales se vincula.

Este obstáculo no previsto limitó los alcances de la primera etapa a la vez que nos abrió nuevos interrogantes fundados en la invisibilidad no solo de los programas en sí, sino de los beneficios y beneficiarios. Así se nos abría un camino de múltiples aristas: ¿cómo efectuar el abordaje de la problemática teórica respecto a la superposición de recursos en los diversos niveles de gobiernos, y transversalmente entre las diversas dependencias que implementan políticas sociales, cuando los datos mínimos no podían recolectarse?

La falta de datos relativa a la evaluación de cada programa por parte de los organismos municipales, del Gobierno de la Provincia de Buenos Aires y del Gobierno Nacional, así como de información respecto de la trayectoria de los Programas en territorio (de los nacionales, provinciales), que dieran cuenta de seguimientos de estos, han sido recabados como hallazgo de la investigación, a la vez que se presentó como una limitación a la ejecución a nuestro proyecto de investigación.

Las revelaciones mencionadas lograron ser reemplazadas con otra estrategia de recolección de información (entrevistas a informantes claves).

De esta forma para recomponer el conocimiento sobre los programas se partió de programas existentes en la zona al momento del relevamiento y de los cuales se tenía conocimiento a través de algunos referentes.

Debido a los escasos antecedentes recolectados, esta tarea de exploración -limitada debido a la desactualización de las plataformas digitales- fue acompañada por entrevistas a referentes barriales e institucionales. Así, durante la primavera de 2015 y el otoño de 2016 se inició un trabajo de campo que aportó los primeros resultados parciales que brindaron mayor conocimiento sobre la problemática en estudio. Las entrevistas a los referentes se extendieron a los participantes de las actividades culturales desarrolladas en las áreas de influencia de los Puntos Culturales No 2 Isla Maciel, No 3 Villa Tranquila, No 4 Dock Sud y, No 10 y N 11 Villa Corina. Durante la primera etapa de trabajo de campo (concluida en mayo de 2016), se realizaron 193 encuestas (Villa Corina 48, Dock Sud 65, Isla Maciel 30, Villa Tranquila 50); 7 entrevistas a miembros de asociaciones civiles y 5 funcionarios del municipio; y se filmaron 9 entrevistas en territorio ( 6 a referentes barriales y 3 a participantes/beneficiarios de los programas).

El trabajo en territorio arrojó la primera sorpresa: la necesidad de ampliar el espectro de búsqueda. Los habitantes de estos barrios recibían subsidios de programas bajo la órbita de dependencias estatales que en principio no nos habíamos propuesto relevar, pero una vez en el campo, se comprobó que el recorte propuesto iba a sesgar los resultados. También 
observamos que la mayoría de los vecinos desconocía no solo el área de "impacto" vinculada con las actividades y/o planes (social, educacional, cultural) sino incluso la dependencia gubernamental que ejecutaba los programas (fuera esta de nación, provincia o municipio). Este problema técnico que impedía "medir" correctamente el conocimiento ciudadano de los programas de inclusión social, a veces se originaba en el entrecruzamiento de los diferentes niveles de gobierno. Por ejemplo, el Plan FinEs 2 es un programa educativo impulsado por el Ministerio de Educación de la Nación, la Dirección General de Cultura y Educación de la Provincia de Buenos Aires, y el Ministerio de Desarrollo Social de la Nación, ¿cómo debe clasificarlo el vecino y el equipo de trabajo? La necesidad de relevar la superposición de programas de diversas áreas determinó la incorporación de programas, planes y/o actividades implementadas por áreas como Desarrollo Social y Salud.

La reconstrucción de la interacción en el territorio de programas nacionales, provinciales y municipales vigentes durante el año 2015, generada a través de las entrevistas, brindó el insumo necesario para comenzar a elaborar el primer borrador de la encuesta a realizar en la población objeto de Villa Tranquila, Isla Maciel y Dock Sud.

Debido a los obstáculos encontrados (ausencia de portales digitales, problemas de comunicación entre responsables/administrativos que ejecutan los programas y los destinatarios, escaso conocimiento de los programas en curso en Avellaneda que no dependían del gobierno municipal por parte de sus funcionarios) tomamos la decisión de incorporar un nuevo barrio: la primera prueba piloto del cuestionario se realizó en Villa Corina, zona en la que hasta ese momento no habíamos realizado trabajo de campo. Su elección se debió a que nos permitía: a) la justificación metodológica y teórica de los ajustes realizados en las actividades del proyecto; y, b) el testeo de los hallazgos localizados hasta ese momento. De este modo, pudimos comparar similitudes y diferencias en los cuatro barrios, para analizar en qué medida impactaba en la calidad de vida de las personas un aspecto que el análisis de los datos mostró relevante: la cercanía/lejanía de la localidad de Avellaneda, cabecera del partido y sede del palacio municipal respecto a la condición de estos barrios como "frontera territorial". En los cuatro casos limitaban con otros distritos: Villa Corina con el Partido de Lanús y Villa Tranquila, Isla Maciel y Dock Sud con el Riachuelo y el Río de la Plata, que los separa de la Ciudad Autónoma de Buenos Aires. De los 40 casos relevados en Villa Corina, la información recolectada resultó coincidente con la recabada seguidamente en Dock Sud.

Este relevamiento in situ permitió la elaboración de un primer mapa donde se localizaron las instituciones en territorio. El equipo pudo iniciar un análisis de las imágenes que se iban relevando tanto de aspectos expuestos en la bibliografía como de los atributos señalados por sus habitantes. En relación con los primeros, registramos la segregación territorial, es decir, ubicación geográfica marginal de los barrios dentro del partido (a pesar de la cercanía respecto a Buenos Aires, capital del país y su centro financiero); en relación con los segundos (es decir, las propias diferenciaciones manifestadas por sus habitantes) cada barrio internamente también tenía clasificaciones y jerarquizaciones propias. (Ver Figuras 4 y 5 ) Esta constatación determinó la realización de una serie de mapas (dos de los cuales se acompañan), que en la actualidad todavía se encuentran en proceso de elaboración, debido a que continuamente se van modificando en función de los datos que surgen de la propia investigación. Estos mapas conformarán una cartografía que contará con información de 


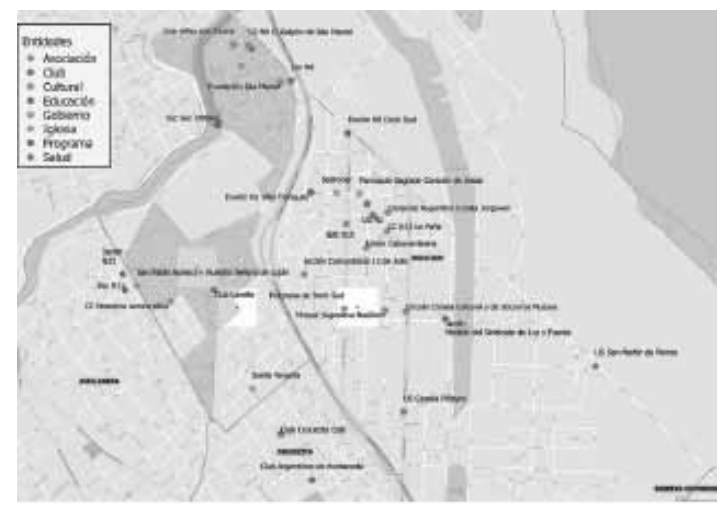

Figura 3.

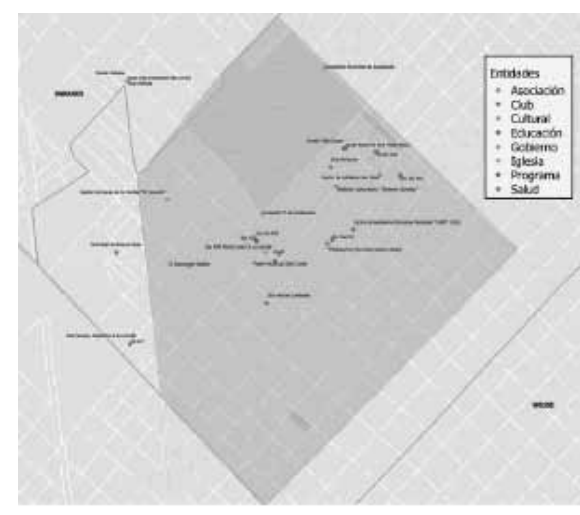

Figura 4 .

Figura 3. Revelamiento en Villa Tranquila, Isla Maciel y Dock Sud. Adviértase de la continuidad territorial. Mapa elaborado por Nicolás Diéguez. Figura 4. Revelamiento en Villa Corina. Mapa elaborado por Nicolás Diéguez.

las áreas donde se encuentran las instituciones en los barrios, cuales son las zonas donde desarrollan sus actividades los informantes claves y la yuxtaposición de programas/planes que aporta la carga de las encuestas, entre otros. La cartografía reunirá así la información recolectada en campo.

El testeo del instrumento confeccionado manifestó dos problemáticas: la primera fue la necesidad de realizar ajustes en el lenguaje empleado de forma de garantizar que los entrevistados comprendieran las preguntas. De este modo, el vocabulario utilizado debió adecuarse a las palabras y denominaciones que los vecinos empleaban cotidianamente para referirse a las dimensiones que se buscaban medir. La segunda dificultad refería a las pocas respuestas espontáneas obtenidas, situación que obligó a focalizarse en el tipo de preguntas que los encuestadores debían realizar para obtener una contestación que refiriera al ítem indagado, aun cuando estas no estuvieran en el formulario. Durante la primera etapa de trabajo de campo, las dificultades surgidas motivaron la revisión de las estrategias metodológicas desplegadas y los cambios necesarios cuando esta se volvía ineficaz.

A pesar de estos obstáculos, la primera aproximación brindó información respecto a las características de los programas y planes en ejecución en los barrios encuestados: espacios donde se llevaban a cabo, grupos sociales y etarios a quienes estaban dirigidos, personas que asistían, grado de apropiación de las actividades por parte de éstos y un sondeo comparativo entre los resultados esperados con aquellos efectivamente alcanzados.

Del elevamiento realizado en los Puntos Culturales ( 92 encuestas sistematizadas en la base de datos) se logró conocer que el 50\% de los vecinos participaba de algún programa de asistencia nacional, mientras que el $42 \%$ sabía de la existencia de los programas a través de 
algún conocido. Alcanzar este nivel de respuesta fue posible al reconocer la dificultad que presentaba para los vecinos desconocer la diferencia entre los distintos niveles de gobierno. Así, el 83,7\% de los encuestados dijo no participar de ningún programa del gobierno provincial. Sin embargo, la mayoría de estos recibía el Plan más Vida, pero desconocía el origen provincial del subsidio. Incluso mencionaron "el bolso de alimentos" -al cual reconocieron acceder gracias a conocidos- como un programa específico del municipio debido a que lo tramitaban en una dependencia de este gobierno, cuando es un beneficio de este plan.

Asimismo, el $81,5 \%$ participa de un programa municipal, la mayoría en un punto de encuentro en actividades como peluquería yoga, deportes, talleres madera y vitraux.

La difusión local es el recurso que emplean los vecinos para acceder a la prestación: toman conocimiento porque quedan en el barrio y tramitan en el propio punto la inscripción. El 73,9\% de los encuestados dice conocer los talleres que se dictan en el punto cultural barrial por difusión "oficial” (volantes) e informal (boca en boca).

El $57,7 \%$ asiste a alguna de estas instituciones barriales (iglesia, club, sociedad de fomento, polideportivo, punto cultural). La difusión también es "oficial" (volantes) e informal (vecinos). El 88,7\% conoce las actividades de la institución donde asiste. Cuando se pregunta por los talleres que no se dan y le gustaría participar, aparece: maquillaje, electricidad, peluquería, soldadura, asistente social, maestra jardinera, carpintería, prevención de drogas, orientación laboral, idiomas, asesoramiento microemprendimientos y legal, técnico en computación, apoyo escolar en secundaria, decoración con venecitas, taller administrativo y contable, taller contención familiar, gastronomía, panadería, apoyo escolar, entre otros. Los talleres vinculados con la oferta cultural son menos solicitados que estos talleres más vinculados con la resolución de sus problemas cotidianos.

En el territorio, al acercarnos a las instituciones y a los beneficiarios se detectó como obstáculo de los planes/programas, el problema de interacción comunicativa entre los miembros del proyecto y los beneficiarios/participantes. En una primera etapa debido a la campaña electoral ya mencionada, y a partir de este año, como consecuencia del cierre abrupto o reducción de los planes/programas vigentes, los beneficiarios en algunas zonas se muestran recelosos a contestar las preguntas.

La diversidad de riesgos e imponderables a los cuales se enfrentó el proyecto orientan a proponer la matriz como el punto de llegada y no de partida. Una realidad dinámica que visibilizó hallazgos y nuevos escenarios a tener en cuenta al momento de la evaluación del impacto de los programas y especialmente en las interacciones entre el nivel estatal, el nivel de la sociedad civil y el nivel individual.

Las entrevistas condujeron la mirada hacia la distancia existente entre el ámbito donde se diseña la política social (el área estatal) y el plano individual, es decir, las relaciones que se entrelazan entre el beneficiario y el responsable de la política cultural y/o educacional, sea este el mediador en el barrio -la difusión descansa fundamentalmente en las redes de afinidad- o el funcionario/empleado a cargo de las actividades en el territorio. El hallazgo de la invisibilización de los programas, sumado a falencias comunicacionales que repercutían tanto en las instituciones donde se implementaban los proyectos como entre los actores (personal de los organismos públicos, dirigentes barriales y beneficiarios) se presentaron como dimensiones de análisis a priorizar en el proyecto. 


\section{Algunas reflexiones preliminares}

De la información relevada a prima facie, se puede observar que a mayor cantidad de actividades, mayor la diversificación en la oferta; esta oferta en algunos casos poco tiene que ver con propuestas culturales, sino más bien con la salud y/o recreación (gimnasia), salida laboral (peluquería, electricidad) y con programas de sustentabilidad (huerta y reciclado). La demanda de actividades vinculadas con el aprendizaje de oficios confronta a los funcionarios municipales con la disyuntiva de satisfacer las demandas de los vecinos que diariamente "piden" talleres de oficio y "revisar" el fin de los Puntos Culturales o mantener el fin para el cual fueron creados. El coordinador de un Punto consideró que ambas opciones generan una tensión entre ciudadanía y funcionarios municipales que es compleja de revertir. Para algunos papás que llevan a sus hijos a los talleres el punto debía ser una instancia para brindarles a futuro una mejor calidad de vida (mayores calificaciones profesionales). Acuciados por la vulnerabilidad económica, los encuestados manifestaron una necesidad recurrente de talleres de oficio en lugar de actividades vinculadas con el arte, en cualquiera de sus manifestaciones.

Como ya se mencionó, uno de los objetivos de la investigación era ponderar el grado de apropiación de los participantes en programas. Los hallazgos de las entrevistas y de las encuestas fueron diversos. Un primer dato sorprendente es que la apropiación no cobra el mismo sentido para los actores involucrados en los diversos Puntos Culturales del Municipio. Por ejemplo, los talleres de vitro fusión que en la clase media cumplen una función recreativa, en estos grupos se cursan como una salida laboral. Asimismo se constató que la mayoría de las actividades se encuentran focalizadas hacia niños y adolescentes, los talleres para adultos son menos frecuentes y, entre estos, la concurrencia de las mujeres es superior a la de los hombres, debido al porcentaje que permanece en el hogar (amas de casa) respecto a los hombres.

Las entrevistas dejan un interrogante a develar a futuro, ¿estos programas funcionan informalmente solo a través "personas" que realizan los "pedidos"? ¿Qué grado de institucionalidad tienen? Por lo tanto, la metodología de acceso a la información debe realizarse a partir de un estudio que vaya "desde adentro para afuera", porque así lo perciben las personas a quienes van dirigidas; la matriz a transferir debe diseñarse, en consecuencia, desde la perspectiva nativa para que a futuro el municipio pueda replicar la experiencia en otros barrios del territorio.

Los resultados preliminares presentados llevan a interpelar las nociones de política pública y a preguntarnos por la resignificación del concepto de apropiación desde los propios actores.

\section{Notas}

1. Las ideas aquí desarrolladas se originan en el proyecto PDTS 2013 "Diseño de una matriz para optimizar la gestión del gobierno local en Villa Tranquila, Isla Maciel y Dock Sud", dirigido por Laura Ferreño y co dirigido por María Laura Giménez. El PDTS cuenta con financiamiento de la UNDAV y fue incorporado al Banco Nacional de Proyectos de 
Desarrollo Tecnológico y Social (PDTS) del Ministerio de Ciencia, Tecnología e Innovación Productiva, código del proyecto: PCTI - 208 (http://pdts.mincyt.gob.ar/proyectos/). 2. Esta es la denominación que recibe el último tramo del río Matanza antes de su desembocadura en el Río de la Plata.

3. Su propósito fue ofrecer a los jóvenes y adultos de todo el país la posibilidad de finalización de sus estudios primarios y/o secundarios a través de la implementación de un plan específico, adaptado a sus posibilidades y necesidades. Datos relevados en http://www. me.gov.ar/consejo/resoluciones/res08/66-08-anexoly2.pdf (consultada el 5/01/2017).

4. Pago mensual por cada hijo menor de 18 años, hasta un máximo de 5 hijos, priorizando a los hijos discapacitados y a los de menor edad. Lo abona ANSES a aquellas personas: desocupadas, trabajadores informales con ingresos iguales o inferiores al Salario Mínimo, Vital y Móvil, monotributistas sociales, trabajadores del servicio doméstico. También lo perciben quienes reciben un plan: Argentina Trabaja, Manos a la Obra, Ellas Hacen. Datos relevados en http://www.anses.gob.ar/prestacion/asignacion-universal-por-hijo-92 (consultada el 5/01/2017).

5. Programa focalizado en personas sin ningún ingreso formal ni programa social. Sus titulares adquieren habilidades que mejoran su empleabilidad. La capacitación les proporcionamos un ingreso y la oportunidad de acceder o continuar con su educación primaria, secundaria o asistir $s$ talleres de alfabetización en caso de que no sepan leer y escribir. Datos relevados en http://www.desarrollosocial.gob.ar/argentinatrabaja (consultada el 5/01/2017).

6. Brinda a mujeres que atraviesan una situación de vulnerabilidad el acceso a oportunidades de trabajo y formación. Datos relevados en http://www.desarrollosocial.gob.ar/ ellashacen (consultada el 5/01/2017).

7. Destinado a jóvenes argentinos o naturalizados con 5 años de residencia (entre 18 y 24 años inclusive), desocupados o con trabajo informal o formalmente con ingresos menores a 3 salarios mínimo, vital y móvil. Datos relevados en http://www.progresar.anses.gob.ar/ programa (consultada el 5/01/2017).

8. Dirigido a familias en condiciones de vulnerabilidad social, embarazadas, madres en período de lactancia y niños hasta los seis años. Su objetivo principal es mejorar las condiciones de nutrición, crecimiento y desarrollo de la población materno infantil, fortaleciendo las capacidades de las familias y consolidando las redes sociales. Datos relevados en http://www.desarrollosocial.gba.gov.ar/Subsecretarias/FortalecimientoFamiliarComu nitario/MasVida (consultada el 5/01/2017).

9. El Programa de Responsabilidad Social Compartida Envión, está destinado a chicos entre 12 y 21 años que se encuentran en situación de vulnerabilidad social. El objetivo esencial es la inclusión, la contención, el acompañamiento y el diseño de estrategias que fortalezcan su estima, reparen y brinden igualdad de oportunidades. Datos relevados en http://www.desarrollosocial.gba.gov.ar/Subsecretarias/PoliticasSociales/Envion (consultada el 5/01/2017).

10. Ofrece a los vecinos talleres de formación y recreación de manera descentralizada, gratuita y cerca de sus casas. Datos relevados en http://puntosculturales.blogspot.com.ar/ (consultada el 5/01/2017).

11. Programa municipal de separación de residuos en origen. Datos relevados en https:// es-la.facebook.com/Avellaneda-Recicla-1485234475026069/ (consultada el 5/01/2017). 
12. Ubicado en Sarandí, Avellaneda. Tiene pileta climatizada y canchas de fútbol y tenis, entre otros. Datos relevados en (consultada el 5/01/2017).

\section{Referencias Bibliográficas}

Abélès, M. (2005). Anthropologie de l'État. Paris: Petit Bibliotheque Payot.

Álvarez, G. H. (2005). “Gran Buenos Aires, conurbano y Partido de San Martín: Exclusión social y segregación urbana”. En Scripta Nova, revista electrónica de Geografía y Ciencias Sociales, Universidad de Barcelona, Vol. IX, núm. 194 (52), 1 de agosto de 2005. En http:// www.ub.edu/geocrit/sn/sn-194-52.htm [consultada el 15 de agosto de 2015].

Auyero, J. (2004). Clientelismo político. Las caras ocultas. Buenos Aires, Capital intelectual. Auyero, J. (2012). La política de los pobres. Las prácticas clientelistas del peronismo. Buenos Aires, Manatial, $2^{\text {a }}$ ed. Prefacio.

Auyero, J. (1998). “Desde el punto de vista del cliente. Repensando el tropo del clientelismo político”. En Apuntes de Investigación del CECyP, Núm. 2, Cultura / Política - Política / Cultura (No $2 / 3$ doble).

Auyero, J. y Swistun D. (2007). "Expuestos y confundidos. Un relato etnográfico sobre sufrimiento ambiental". En Iconos. Revista de Ciencias Sociales. Num. 28, Quito, enero 2007, pp. 137-152

Balán, P. (2015). “El Estado en la ciencia social moderna: conceptos, medición, indagación casual”. En Estudios Sociales del Estado, volumen 1, número 1, primer semestre de 2015, pp. 205-236.

Boivin, M. (2001). “Clientelismo y Patronazgo. Desarrollo histórico de ambos conceptos en la teoría antropológica y su discusión actual”. Ficha de cátedra.

Cantamutto, F. (2015). “Construcción de hegemonía y Estado: algunas bases teóricas”. En Estudios Sociales del Estado, volumen 1, número 1, primer semestre de 2015, pp. 171-203.

Cruces, G. y Rovner, H. (2008). “Los programas sociales en la opinión pública. Resultados de la Encuesta de Percepción de Planes Sociales en la Argentina”. En Cruces, Guillermo, Moreno Juan Martín, Ringold, Dena y Rofman, Rafael. Los programas sociales en Argentina hacia el Bicentenario: visiones y perspectivas. Buenos Aires, Banco Mundial, $1^{\text {a }}$ ed.

Espinosa Molina, E. (2015). “Notas sobre la dificultad de etnografiar el Estado”. En Estudios Sociales del Estado, volumen 1, número 2, segundo semestre de 2015, pp. 175-186.

Ferreño, L. (2011). "Derechos culturales, ciudadanía y desconcentración de las Políticas culturales. Municipio de Avellaneda, Provincia de Buenos Aires”. Sexto Congreso de Administración Pública, Resistencia (Chaco), 5,6, 7 y 8 de julio de 2011.

Ferreño, L. (2014). “En nombre de los otros'. Ciudadanía y políticas culturales”. En Grimson, Alejandro (comp.), Culturas políticas y políticas culturales, Buenos Aires, Ediciones Böll Cono Sur - CLACSO.

Ferreño, L. (2013). “Políticas culturales e inclusión ciudadana”. Séptimo Congreso Argentino de Administración Pública, Mendoza, 18,19 y 20 de setiembre. En https://aaeap.org.ar/ wp-content/uploads/2013/7congreso/Ferreno_Laura_Politicas_culturales_e_inclusion _ciudadana_Panel_050.pdf 
Golbert, L. (2004). ¿Hay opciones en el campo de las políticas sociales? El caso del gobierno de la Ciudad Autónoma de Buenos Aires. Buenos Aires, CLACSO Libros.

Lomnitz, L. (1975). Como sobreviven los marginados. México, Siglo Veintiuno Editores.

Lomnitz, L. (2001). "Redes informales de intercambio en sistemas formales: un modelo teórico". En Facultad Latinoamericana de Ciencias Social -FLACSO- sede México, segunda reimpresión, capítulo IV.

Mair, P. (2015). "El patronazgo partidario como recurso organizativo". En Casal Bértoa, Fernando y Scherlis, Gerardo (comp.), Partidos, sistemas de partidos y democracia. La obra esencial de Peter Mair. Buenos Aires: Eudeba.

Ringold, D. y Rofman, R. (2008). "Argentina: políticas de transferencia de ingresos hacia el Bicentenario". En Cruces, Guillermo, Moreno Juan Martín, Ringold, Dena y Rofman, Rafael. Los programas sociales en Argentina hacia el Bicentenario: visiones y perspectivas. Buenos Aires, Banco Mundial, $1^{\text {a }}$ ed.

Rivas, P. (2007). "La investigación cultural como tensión democrática”, V Campus Euroamericano de Cooperación Cultural, Almada (Portugal).

Rosato, A. (2009). Introducción: "El hacer política: cotidianeidad y delimitación del dominio político". En BOIVIN, Mauricio; HEREDIA, Beatriz; ROSATO, Ana (comp.). Política, instituciones y gobierno: abordajes y perspectivas antropológicas sobre el hacer política. Buenos Aires: Editorial Antropofagia, GIAPER (Grupo de Investigación en Antropología Política y Económica Regional), Serie Antropología Política y Económica.

Segura, R. (2006). Segregación residencial, fronteras urbanas y movilidad territorial. Un acercamiento etnográfico. Buenos Aires, Cuadernos del IDES $\mathrm{N}^{\circ} 9$.

Vich, V. (2014). Desculturizar la cultura. La gestión cultural como forma de acción política. Buenos Aires, Siglo XXI editores.

Vommaro, G. (2008). "Diez años de ¿Favores por votos? El clientelismo como concepto y como etiqueta moral”. En Eduardo Rinesi, Gabriel Vommaro y Matías Muraca (comp.). Si éste no es el pueblo. Hegemonía, populismo y democracia en Argentina. Los Polvorines, Universidad Nacional de General Sarmiento: Instituto de Estudio y Capacitación - Federación Nacional de Docentes Universitarios.

Wacquant, L. (2013). Los condenados de la ciudad. Gueto, periferias y estado. Buenos Aires, Siglo XXI editores.

Wolf, E. R. (1980). "Relaciones de parentesco, de amistad y patronazgo en las sociedades complejas”. En Banton, Michel (comp.), Antropología social de las sociedades complejas. Madrid: Alianza Editorial.

Abstract: The study of the impact of inclusive social and cultural policies at the different Government levels (national, province and local) in the neighbourhoods of Dock Sud, Isla Maciel, Villa Tranquila and Villa Corina (District of Avellaneda) revealed both the absence of information regarding the programs in course of implementation and the lack of evaluation (before, during and post) and connections between the government teams and programmes. 
The research examined the impact of these policies. It identified the needs expressed by the neighbours in the areas surveyed, according to their specificity - population at risk due to living in settlements formed several decades ago in areas with high rates of pollution, high population density, labour precariousness, amongst other indicators. The data analysis provided several findings, amongst which the gap between the needs of the population and the programmes implemented. Those needs are masked not only by the limited evaluation of them carried out by the public management, but also by the naturalization of the notions and concepts from where they were designed and executed. The article will analyse the tensions between the government institutions running the public policies and the people to whom these policies are addressed.

Key words: Government - Social Policy - Inclusion - Citizenship - Vulnerable Sectors.

Resumo: $\mathrm{O}$ estudo do impacto da política inclusivo sócio-cultural das, diferentes níveis de governo (nacional, provincial e municipal), nos bairros de Dock Sud, Isla Maciel, Villa Tranquila e Villa Corina (Partido de Avellaneda) revelou tanto a ausência de informações sobre os programas em execução como ele falta avaliações (antes, durante e pós) e de articulação entre programas e equipamentos de trabalho de governo.

A pesquisa examinou o impacto destas políticas e detectou as necessidades expressadas pelos residentes nas áreas pesquisadas de acordo com sua especificidade (população em risco devido a viver em assentamentos há décadas que residem em áreas com altos níveis de poluição ambiental, habitantes de alta densidade / metro quadrado, a insegurança no trabalho, entre outros indicadores de emprego). A análise dos dados desde encontra vários, entre eles, o intervalo entre eles, necessidades da população e os programas implementados, precisa tanto pela avaliação limitada do gerenciamento público, mascarados como pela naturalização de noções e conceitos a partir do qual é projetado e execução.

O artigo discutirá as tensões entre as instituições governamentais que executam essas políticas públicas e aqueles que "são dirigidas".

Palavras chave: Governo - política social - inclusão - cidadania - sectores vulneráveis. 

Fecha de recepción: marzo 2017 Fecha de aceptación: octubre 2017 Versión final: marzo 2019

\section{El Distrito de Diseño en la Ciudad de Buenos Aires: una mirada desde los usos de la cultura en contextos globales y locales}

Silvia Benza*

\begin{abstract}
Resumen: Este artículo propone un análisis sobre el Distrito de Diseño en la Ciudad de Buenos Aires, tomando en cuenta contextos globales en los que se enmarca su creación, como el programa de Red de Ciudades Creativas de la Alianza Global para la Diversidad Cultural, así como una instancia local, representada por el Ministerio de Desarrollo Económico del Gobierno de la Ciudad. Se apunta a tomar en cuenta el uso intensivo del diseño, focalizando en su vinculación con políticas culturales y políticas de desarrollo urbano que impulsan procesos de "revitalización" urbana, de gentrifricación y de creación de clusters. Se propone también analizar los usos de la cultura en estos procesos, tomando en cuenta los usos "instrumentales" y sus usos en tanto "valor público". Para esto deberán contemplarse las políticas del sector público y de gobiernos, las industrias, la lógica del mercado y la dimensión empresarial, el capitalismo neoliberal, y por último, el tercer sector.
\end{abstract}

Palabras clave: Ciudad - Diseño - Cultura.

[Resúmenes en inglés y portugués en las páginas 58-59]

${ }^{(*)}$ Licenciada en Ciencias Antropológicas y Magister en Administración Cultural (Universidad de Buenos Aires). Docente de la Universidad de Buenos Aires. Integrante del Equipo de Antropología de las Ciudades, Facultad de Filosofía y Letras, Universidad de Buenos Aires.

En el año 2005, la Organización de las Naciones Unidas para la Educación, la Ciencia y la Cultura (UNESCO) nombra a Buenos Aires como la primera Ciudad de Diseño en el marco de su programa de Red de Ciudades Creativas de la Alianza Global para la Diversidad Cultural. Por este motivo, el Ministerio de Desarrollo Económico del Gobierno de la Ciudad de Buenos Aires y la Dirección General de Industrias Creativas impulsa la creación del Distrito de Diseño desde el año 2013, motivando a empresarios, profesionales y emprendedores a incorporar el diseño en la práctica y la estrategia de sus negocios. Se presupone entonces que el Diseño es un factor de mejora para el conjunto de la sociedad, que contribuye al progreso de la ciudad, y que eleva la calidad de vida y el bienestar de las personas, todo ello de modo sostenible (Becerra, 2013).

El Ministerio de Desarrollo Económico impulsa una estrategia de creación de distritos productivos en la Ciudad, para estimular la radicación de productores y proveedores de 
un mismo sector productivo en un área geográfica delimitada. El objetivo central es reordenar la trama productiva de la Ciudad, construir nuevas centralidades y generar polos capaces de competir internacionalmente en la atracción de inversiones en torno a las actividades relacionadas con el uso intensivo del diseño. Para ello, se propone fomentar la radicación, dentro de un mismo territorio, de las empresas que ofrecen servicios de diseño con aquellas que los demandan, promoviendo la efectiva incorporación del diseño en la manufactura como herramienta de competitividad. También se impulsa la integración de instituciones educativas, profesionales o de oficios, y su rol como dinamizadores del sistema, incluyendo a universidades, escuelas, institutos técnicos y terciarios asegurando así la continua formación de los actores que darán vida al distrito, la denominada "clase creativa" vinculada al diseño (Becerra, Rondina, Kogan, 2013).

En este contexto, desde la Dirección General de Industrias Creativas se impulsa la Ley de Distrito de Diseño ${ }^{1}$. Este incentivo supone la revitalización urbana de Barracas, generando circulación y "empleo de calidad", y acompañando los negocios locales con propuestas culturales. La Ley de Distrito de Diseño propone una zona libre de impuestos municipales (ABL, sellos e ingresos brutos), líneas de crédito preferenciales acompañadas por políticas y herramientas de fomento para la incorporación de diseño e internacionalización de los negocios basados en diseño.

De esta manera se impulsa el establecimiento de las industrias creativas inspiradas en el diseño, como la arquitectura y el diseño de interiores, el estilismo de moda y el diseño textil, los accesorios y joyería, la comunicación visual, el diseño digital e interactivo, el diseño urbano, el diseño para el desarrollo durable.

\section{Usos de la cultura en procesos de revitalización urbana, gentrificación y creación de "clusters"}

Las primeras estrategias de revitalización urbana que tuvieron en cuenta políticas culturales se propusieron en la década de los setenta en Estados Unidos (Bianchini y Parkinson, 1993). En esta época la política cultural local de las arts agencies sirvió en parte para apaciguar manifestaciones y motines, y coincidió con proyectos de desarrollo para los centros deshabitados en muchas ciudades estadounidenses (Yúdice, 1999). En Europa occidental, las políticas culturales urbanas surgieron a partir de la descentralización gubernamental hacia las regiones y los municipios en los años setenta y ochenta (Bianchini y Parkinson, 1993). El uso de la cultura llegó a predominar para proyectar una imagen glamourosa de las ciudades, incluso transformando a algunas como Frankfurt en importantes centros de cultura. El "modelo Barcelona" ha sido el más exitoso en la creación de una "imagenmarca”, si bien ha engendrado una serie de conflictos en torno a la gentrificación ${ }^{2}$ y la prioridad de la puesta en valor del suelo por encima del bienestar humano.

Estrategias como éstas han sido descriptas por David Harvey (1989, en Bianchini y Parkinson, 1993) como políticas culturales de revitalización urbana que contribuyen a una "máscara carnavalesca" que encubre la reestructuración en favor del capital privado local en alianza con el internacional. Según este autor, las nuevas políticas culturales van más allá de disciplinar o normar a los ciudadanos y se convierten en políticas económicas. El modelo 
es el de las "ciudades creativas", que se está reproduciendo alrededor del mundo, por el que se busca establecer ambientes creativos, redes y conglomerados (clusters) de innovación. Un contraste con este modelo de "ciudades creativas" lo constituyen, en América Latina, las ciudades de Bogotá y Medellín, urbes caracterizadas por el conflicto de clases y los más altos índices de homicidio. Para el caso de Bogotá, se puso en marcha el Programa de Cultura Ciudadana durante el gobierno de Antanas Mockus (1995-1997), una política cultural que buscaba revertir la informalidad, el deterioro de lo público, la falta de respeto a la propiedad, el clientelismo, y otras "deficiencias sociales y morales" que se consideraba que impedían afianzar los lazos de sociabilidad. Yúdice (2008) señala que en lugar de promover una "mejora" de las condiciones urbanas mediante la expulsión de las clases menos pudientes y su remplazo por la "clase creativa" (ingenieros de software, diseñadores, creadores de programas en los viejos y nuevos medios, etcétera), que conduce a una mayor segregación, la gestión de Bogotá y Medellín han buscado mejores condiciones urbanas para todos, además de fomentar el contacto y la comunicación entre grupos sociales.

Según Jamie Peck (2005), el nuevo imperativo urbano consiste en que las ciudades deben atraer a las nuevas "clases creativas", con barrios de moda, escenas de arte y atmósferas amigables con los gays. Con este guión de desarrollo urbano que penetra cada vez más, se alude a un nuevo tipo de capitalismo basado en la creatividad humana, en el que las ciudades se encuentran en una "guerra de talentos", que solo puede ser ganada desarrollando ambientes urbanos abiertos, diversos, dinámicos y "cool”. Estos proyectos trabajan con "agendas" de desarrollo neoliberal, enmarcadas en la competencia interurbana, el consumo de la clase media y el marketing de lugares. Uno de los autores que respaldan estas ideas es Richard Florida (2014), quien sostiene que hemos ingresado en la era de la creatividad, comprendida como una nueva y distintiva fase del desarrollo del capitalismo, en la que las fuerzas que conducen al desarrollo económico no son simplemente tecnológicos y organizacionales, sino humanos. El autor apunta a describir una nueva economía, en la que la creatividad humana se ha convertido en el rasgo definitorio de la vida económica. Las viejas categorías de análisis de clase serían inadecuadas y la única propiedad con prominencia sería la nueva capacidad creativa de la clase, la cual sería intangible porque estaría literalmente en sus cabezas. Entonces, el crecimiento derivaría de la creatividad y por lo tanto es la creatividad la que posibilitaría el crecimiento. A este respecto, Peter Hall señala que estos procesos convocan a pensar en los conceptos de "consumo cultural" y "producción cultural", y en el papel de las ciudades. Más precisamente, Pratt (2008), retoma el punto de vista marxista, que veía a la producción como un complemento necesario del consumo, como co-dependientes. Este autor también señala que debe haber un examen más profundo de los poderes causales de la creatividad y que tal vez sea necesario hablar más de una economía neo-industrial que de una post-industrial.

En estos procesos, es preciso referirse al concepto de "clusters", en sintonía con el proyecto de crear "distritos culturales" del Gobierno de la Ciudad. Porter (2000), define al Cluster como "concentraciones geográficas de compañías interconectadas, proveedores especializados, firmas en industrias relacionadas, e instituciones asociadas (universidades, agencias standard, asociaciones de comercio)", en un particular campo que compite pero que también coopera. La prevalencia de los clusters revela importantes ideas acerca de la microeconomía de la competencia y el rol de la ubicación en la ventaja competitiva. Los 
clusters no pueden ser entendidos independientemente de una teoría más amplia de la competencia y de una estrategia de competencia en la economía global. En muchas ciudades europeas y de Estados Unidos, luego del colapso de las industrias pesadas tradicionales que sustentaban su tejido económico, las agencias de desarrollo urbano de muchas ciudades industriales trabajan duro para reciclar los espacios industriales redundantes como nuevos parques de negocios brillantes para call centers y back offices (Graham and Marvin, 2001). Esta supuesta desintermediación significa efectivamente que los consumidores y proveedores de servicios ya no deben estar ubicados en el mismo lugar.

\section{Instrumentalización y valor público de la cultura}

Las políticas culturales han adquirido un papel esencial en el desarrollo territorial que pretende integrar la economía del conocimiento con la cohesión social, la gobernanza y la sostenibilidad. Para analizar las consecuencias de la política cultural deben tenerse en cuenta dos tendencias que se pueden observar en la literatura especializada: por un lado, las teorías que ponen el énfasis en señalar las externalidades positivas de la política cultural y, por el otro, las que sitúan el acento en el valor público de la cultura. Los análisis que se basan en las externalidades de la cultura enfatizan su supuesta capacidad para contribuir al desarrollo de los objetivos de otras políticas públicas sectoriales: educación, medio ambiente, seguridad, urbanismo, etc. Estas aproximaciones suponen una mirada instrumental de la acción y la política cultural y, en su mayoría, buscan legitimar su existencia poniendo en valor la importancia del papel de la cultura para la consecución de objetivos que se muestran como más prioritarios. Según Clive Gray (2002), estos procesos tienen que ver con cambios más amplios, con contextos en los que la justificación para la misma política ha cambiado, pues está más vinculada a la "mercantilización" de la política pública, que lleva a la instrumentalización de las políticas del arte y la cultura, atribuyéndoles razones no artísticas ni culturales. Las políticas culturales deben proveer así soluciones a problemas que originalmente son económicos, sociales, políticos o ideológicos. La política cultural que es "adjunta", en síntesis, representa una estrategia que permite a un sector "débil" de la política con limitadas influencias políticas atraer recursos suficientes para alcanzar sus objetivos políticos. Sin embargo, estas perspectivas están asumiendo, implícitamente, la poca relevancia de la acción cultural en ella misma.

Existen pocas dudas de que en los últimos años el arte y la cultura han ganado un rol mucho mayor en el debate sobre las políticas públicas (Belfiore, 2006). Según esta autora, el rol de las artes como "adjuntas" a las políticas es claramente visible cuando se financian proyectos culturales en el contexto de programas de regeneración urbana. Una crítica que se hace a esta concepción es que se toma a la cultura como un objetivo y no como un proceso. Una de las limitaciones de la actual literatura sobre los impactos sociales de las artes es asumir que el mismo tipo de impactos proceden de diferentes tipos de actividades culturales sobre diferentes tipos de audiencias. Otra complicación está representada por el hecho de que la frase "impacto social de las artes" se emplea usualmente con referencia a un amplio grupo de métodos de evaluación, que va desde la evaluación de un solo proyecto hasta los efectos de la regeneración urbana culturalmente dirigida. 
Es aconsejable que el concepto de "política cultural" sea abordado desde la perspectiva del lugar que tiene el arte en la inclusión social, favoreciendo la participación y la performance en el mejoramiento de la educación, el incremento de los índices de empleo, la reducción de los niveles de crimen, mejores y más igualitarios standards de salud, mejoras en el desarrollo personal, mejoras en la cohesión social y reducción del aislamiento social, ciudadanía activa (Barraket, 2005). No obstante, no todos estos impactos son susceptibles de medición y factibles de evaluación.

En contraposición con las teorías instrumentales, las teorías que ponen el acento en el valor público de la cultura defienden la necesidad de identificar y analizar los elementos intangibles y de la experiencia asociados a la cultura (Holden, 2004). Esta línea de análisis defiende la cultura como un bien público que aporta beneficios a la ciudadanía y, por lo tanto, el retorno social que se desprende supera la externalidad y se convierte en un componente nuclear de la acción cultural. Se señala la necesidad de desarrollar un lenguaje que reconozca los elementos afectivos, intangibles de la experiencia y la práctica cultural. Se trata, en definitiva, de encontrar las vinculaciones de la cultura con valores permanentes como la equidad y la justicia.

Desde esta perspectiva, los efectos más significativos de las políticas culturales pueden resultar útiles para construir una mirada transversal sobre el valor público de la cultura. El retorno social puede caracterizarse de forma equilibrada entre las capacidades instrumentales y estratégicas de la acción cultural y su valor público y a la vez intrínseco. (Barbieri, Partal y Merino, 2011)

\section{Dinámicas culturales nacionales y globales relevantes para el análisis}

En los procesos de producción, distribución, circulación y consumo cultural, es clave atender al modo que ha adoptado la globalización cultural en la Argentina (Wortman, 2005). En este sentido, si bien se pueden advertir claramente los efectos negativos de la implementación de las políticas económicas neoliberales, resulta más difícil sacar conclusiones contundentes a partir de la observación de modificaciones en las prácticas de consumos culturales. Por ello, en el análisis de la implementación de políticas urbanas a través de políticas culturales, deberá tomarse en cuenta, siguiendo a la autora, que en los usos del tiempo libre, así como en la relación entre tiempo libre y tiempo de trabajo, han surgido nuevos consumos culturales, que deben analizarse en función de su articulación con las formas actuales de presentación del campo artístico. Si bien este impacto es más visible en el ámbito del espacio privado, también debería pensarse en la relación de la gente con la cultura en el espacio público. Al analizar la instalación de empresas de diseño en el barrio de Barracas con el objetivo de crear el Distrito de Diseño, cabe mencionar a Elio Kapszuk (2014), quien afirma que en relación al sector privado, lo primero que uno podría decir es que su misión institucional es obtener la máxima rentabilidad de los productos que realiza o servicios que presta. Si bien esto es verdad, las ramificaciones de las empresas y las campañas relacionadas con la presencia de una marca o la construcción de imagen positiva mediante su asociación a determinados valores, hace que en algunos casos (generalmente relacionados a departamentos de marketing y comunicación, o fundaciones de algunas 
empresas) lo buscado a través del campo cultural sea el fortalecimiento de la imagen institucional que contribuya en última instancia a generar un valor agregado de preferencia de esa marca sobre otra. O sea que, si bien determinado tipo de actividad cultural podría verse como un gasto o en el mejor de los casos como una inversión, en realidad es parte de la estrategia comercial de la empresa. Sobre esta temática, y con mucha relación con el Distrito de Diseño, el autor señala que "no es menos cierto, y por lo tanto esperable, que este campo se amplíe cada vez más tratando de promover desde la gestión cultural un desprendimiento de lo que se ha denominado "responsabilidad social empresaria". El análisis de la creación del Distrito de Diseño implica incorporar lo que Kapszuk denomina “información específica referida a los temas culturales", distintos a otros ámbitos de gestión; es importante tener en cuenta que hay legislación sobre derechos de autor, utilización de imágenes, sobre responsabilidades civiles en actos públicos, ley de mecenazgo, fondos varios de apoyo a la creación artística, legislación sobre donaciones de obras para el sector público, emplazamiento de esculturas en espacios públicos, etc. etc.

Otro factor a tener en cuenta es la relación entre política-comunicación-cultura. En "Dinámicas interculturales”, Jesús Martín Barbero (2008), señala que este tópico está formado por un cuadrilátero: por un lado, habla de políticas del sector público, de gobiernos; por otro, al nombrar medios, comunicación o cultura, se apela indudablemente a industrias y a la lógica del mercado, es decir, al negocio de la cultura y, por tanto, a toda dimensión empresarial. El tercer actor del cuadrilátero es el capitalismo neoliberal que, como la industria y lo público, es una dimensión que a su vez es un actor. Finalmente está el otro actor-dimensión que, de alguna manera, es el tercer sector: los independientes (medios comunitarios y ciudadanos, ONGs, movimientos sociales, medios locales, etc.). El autor propone entrecruzar los cuatro elementos.

Asimismo, señala que es preciso investigar políticas públicas que posibiliten que las culturas se transformen y muestren otras voces distintas a las del "amo del mundo" y que posibiliten el desarrollo de la comunicación entre culturas, pero reconociendo de entrada la diversidad de éstas. También se refiere a la "sostenibilidad cultural", pensando en las dimensiones temporales conflictivas de nuestras culturas y de nuestros productos culturales. En relación a esto deberá tenerse en cuenta que las culturas viven procesos que pueden ser garantizados en tres planos; 1) respecto a la autonomía; 2) respecto a la capacidad de transformarse; 3 ) en tanto a la proyección de la propia cultura hacia fuera de sí misma. Por último, refiriéndose a la investigación de políticas públicas, propone que se debe reflexionar no en términos de recepción, sino de apropiación y de empoderamiento.

\section{Conclusión}

La creación del Distrito de Diseño tiene implicancias a nivel local, ya que se reordena la trama productiva de la Ciudad y se crean nuevas centralidades. También tiene implicancias a nivel global, ya que se generan polos capaces de competir internacionalmente en la atracción de inversiones en torno a las actividades relacionadas con el uso intensivo del diseño. Estos procesos requieren ser analizados tomando en cuenta el vínculo entre políticas culturales y desarrollo urbano, y considerando cómo estos conforman procesos 
de "revitalización” y "gentrificación”. Las capacidades instrumentales y estratégicas de la acción cultural y su valor público y a la vez intrínseco permitirán ver si estos proyectos de revitalización urbana son "máscaras carnavalescas" que encubren la reestructuración en favor del capital privado local en alianza con el internacional, o si favorecen a la creación de ciudadanía.

\section{Notas}

1. A través de la ley $\mathrm{N}^{\circ} 4761$ de Promoción de las actividades de diseño en la Ciudad Autónoma de Buenos Aires, aprobada en noviembre de 2013, se institucionaliza la creación de un Distrito de Diseño y se otorga un horizonte temporal determinado de 15 años con el objetivo de incentivar al sector, dar respuestas a las necesidades de la industria, y a la vez, actuar como el mayor polo generador de creación y producción de diseño.

2. Sobre el concepto de gentrificación, retomamos a Lacarrieu (2016), quien señala que es el desplazamiento y/o recambio de población una de las dimensiones que más se han resaltado sobre este concepto. La idea de desplazamiento es observada como positiva o como negativa. Algunas perspectivas observan la gentrificación como una opción reparadora de lugares deteriorados y el repoblamiento basado en el cambio y en el desplazamiento de población se visualiza como positivo. Muy por el contrario, como lo señalara Herzer (2008, pp. 27-28) cuando el desplazamiento es directo y se ubica en el seno de desalojos compulsivos de sectores populares o, como plantea Rubino (2009), es indirecto y se produce por los cambios socio-económicos que acaban con los viejos residentes del área, estamos ante una perspectiva de alteración y destrucción de las relaciones sociales. En cualquier caso, el desplazamiento y/o recambio se ha naturalizado como una variable, tal vez de ajuste, ineludible y generalizable.

3. El "urbanismo creativo" vinculado a la idea de "ciudad creativa" se define no solo en relación a campos culturales como el arte y el patrimonio, sino también a la capacidad de innovación que aproxima la creatividad a todos los espacios y sectores vinculados al entretenimiento, las industrias culturales, pero también a todo tipo de producciones que exceden el campo institucional y el mercado de la cultura (Lacarrieu, 2016).

\section{Referencias Bibliográficas}

Barbero, J. (2008). "Políticas de la Comunicación y la cultura: claves de la investigación”. Documentos CIDOB. Dinámicas interculturales. 11.

Barbieri, N., Partal, A. y Merino, E. (2011). "Nuevas políticas, nuevas miradas y metodologías de evaluación. ¿Cómo evaluar el retorno social de las políticas culturales?” Papers Revista de Sociología, 96, 2, 477-500.

Barraket, Dr Jo (2005) "Putting People in the Picture? The role of the arts in social inclusion". Social Policy Working Paper No 4. The Centre for Public Policy. University of Melbourne. Becerra, P, Rondina, A y Kogan, H. (2013). Diez Años del CMD. Gobierno de la Ciudad de Buenos Aires. 
Belfiore, E. (2006). “The social impacts of the arts -myth or reality?” En: Mirza, M. ed. (2006) Culture Vultures: Is UK arts policy damaging the arts? London: Policy Exchange Limited Bianchini, F. y Parkinson, M. (1993). Cultural policy and urban regeneration: the West European experience. Manchester University Press.

Florida, R. (2014). The Rise of the Creative Class--Revisited: Revised and Expanded. Basic books.

Graham, S. y Simon M. (2001). Splintering Urbanism. Routledge.

Gray, C. (2002). "Commodification and instrumentality in cultural policy". International Journal of Cultural Policy, 13 (2), 203- 215

Holden, J. (2004). “Capturing cultural value”. Demos, London. 31-36.

Kapszuk, E. (2014). Clase 5a. “ ¿GESTAR O GESTIONAR? De la administración a la creación y realización de proyectos culturales”. Curso: Métodos cualitativos para la investigación social contemporánea: técnicas y claves en etnografía y análisis del discurso. Formación de posgrado virtual Conicet en Flacso.

Lacarrieu, M. (2016) “¡Gentrificación Ahora!. Alcances, limitaciones, retos y desafíos en torno de procesos de negociación y/o disputa”. En: Cambios socioespaciales en las ciudades latinoamericanas: ¿procesos de gentrificación? Yasna Contreras, Thierry Lulle y oscar Figueroa (editores); Vladimir Venegas (traducción capítulo IX), Hernando Saenz Acosta (traducción capítulo XIII). Bogotá: Universidad Externado de Colombia. Pontificia Universidad Católica de Chile. Facultad de Arquitectura, Diseño y Estudios Urbanos. Doctorado en Arquitectura y Estudios Urbanos: Universidad de Chile. Facultad de Arquitectura y Urbanismo.

Peck, J. (2005). “Struggling with the Creative Class". International Journal of Urban and Regional Research.

Porter, M. (2000). "Location, Competition and Economic Development: Local Clusters in a Global Economy”. Economic Development Quarterly. Sage.

Pratt, A. (2008). "Creative Cities: the cultural industries and the creative class". Swedish Society for Anthropology and Geography.

Wortman, A. (2005). "El desafío de las políticas culturales en la Argentina”, en: Mato, Daniel (comp.) Cultura, politica y sociedad. Perspectivas latinoamericanas. CLACSO, Buenos Aires.

Yúdice, G. (2008). "Modelos de desarrollo cultural urbano: ¿gentrificación o urbanismo social?”. Alteridades. Vol. 18. No. 36. México.

\begin{abstract}
This article proposes an analysis of the project Distrito de Diseño in the City of Buenos Aires taking into account the global settings that frame its creation, such as the Red de Ciudades Creativas de la Alianza Global para la Diversidad Cultural (Creative Cities Network of the Global Alliance for Cultural Diversity), as well as a local instance represented by the Ministerio de Desarrollo Económico del Gobierno de la Ciudad (Ministry of Economic Development of the City Hall). It also aims to look at the intensive use of design, focusing on its bonds with cultural and urban development policies that drive processes of urban "revitalization", gentrification, and clustering. Moreover, it proposes to analyze the uses of culture in these processes, considering their "instrumental"
\end{abstract}


use and their use of "public value". To this end, public sector and government policies, industries, the market logic, the business dimension, the neoliberal capitalism, and, finally, the third sector must be considered.

Key words: City - Design - Culture.

Resumo: Este artigo propõe uma análise do projeto Distrito de Diseño na cidade de Buenos Aires tendo em conta os contextos globais em que sua criação se enquadra, como o programa Red de Ciudades Creativas de la Alianza Global para la Diversidad Cultural (Rede de Cidades Criativas da Aliança Global para a Diversidade Cultural), além de uma instância local, representada pelo Ministerio de Desarrollo Económico del Gobierno de la Ciudad (Ministério de Desenvolvimento Econômico da Prefeitura Municipal). O artigo também examina o uso intensivo do desenho, com foco em seus laços com políticas culturais e de desenvolvimento urbano que impulsionam processos de "revitalização" urbana, gentrificação e criação de aglomerados. Além disso, ele se propõe a analisar os usos da cultura nesses processos, tendo em conta os usos "instrumentais" e de "valor público". Para isso, devem ser consideradas as políticas públicas e governamentais, as indústrias, a lógica de mercado, a dimensão empresarial, o capitalismo neoliberal e, finalmente, o terceiro setor.

Palavras chave: Cidade - Desenho - Cultura. 

Fecha de recepción: marzo 2017 Fecha de aceptación: octubre 2017 Versión final: marzo 2019

\section{Las performances musicales en las misiones jesuitas de guaraníes \\ Natalia Aguerre*}

\begin{abstract}
Resumen: Este artículo expondrá cómo la música, sonidos y canto/danzas fueron utilizados por los jesuitas en el proceso de intervención social de las comunidades guaraníes -del actual territorio argentino- durante la conquista española para la eliminación y resignificación de hábitos rituales guaraníes y la adaptación de conductas y actitudes, en clave cristiana.

Indagaremos en los primeros encuentros entre estos grupos para observar cómo los sacerdotes hicieron uso de la música con el propósito de provocar un tipo de sensibilización que les permitiera la reducción de los guaraníes. Observaremos cómo a partir de la constitución de las reducciones, los sonidos y canto/danzas guaraníes fueron re-significados y en qué medida los dramas estéticos musicales cristianos permitieron la creación de espacios de participación que llevaron a la internalización de nuevos comportamientos y sensibilidades. Para el análisis utilizaremos la categoría de performance como comunicación estratégica (Aguerre, 2015), entendiéndola como la escenificación pública de dramas estéticos dentro de un proceso de diseño sociocultural donde la sensibilización y participación actuaron como acciones estratégicas para la transformación social (Massoni y Pérez, 2009).
\end{abstract}

Palabras clave: música - performance - comunicación estratégica.

[Resúmenes en inglés y portugués en la página 74]

${ }^{(*)}$ Licenciada en Comunicación Social y Periodismo, Universidad Nacional de La Plata. Doctora en Comunicación, Universidad Nacional de La Plata. Profesora de grado y posgrado en la Facultad de Periodismo y Comunicación Social de la Universidad Nacional de La Plata; la Facultad de Diseño y Comunicación de la Universidad de Palermo y de posgrado en la Universidad de Quilmes. Integrante de equipos de investigación -UNLP, CLACSO-, que abordan temas sobre arte y política. Fundraiser y Gestora en Comunicación del Centro de Arte Experimental Vigo.

\title{
Introducción
}

Los vínculos de los jesuitas a los pueblos guaraníes estuvieron incentivados por las necesidades geopolíticas de la Corona española. Debido a que los portugueses, instalados 
en Brasil meridional, amenazaban expandirse hacia la colonia del Río de la Plata para así conquistar el Perú y el Alto Perú, la Corona española creó la provincia del Paraguay -1541- con sede en Asunción y dependencia en el Virreinato del Perú, con el objetivo de impedir y controlar el avance de la Corona portuguesa.

Los jesuitas fueron los encargados de reducir a las comunidades guaraníes, pero la intervención no solo implicó la concentración de estos grupos en las reducciones. Los sacerdotes debieron diseñar sus propósitos y acciones para dotar a esos espacios y a las funciones que en ellos se desarrollaban de un enlace simbólico, capaz de instituir una identidad cristiana marcada por saberes, valores, comportamientos, roles y jerarquías de poder mediante los que se organizaría la vida en el espacio misional.

En los primeros encuentros, el desconocimiento de las tribus por parte de los jesuitas hizo imposible establecer acciones programadas (Constituciones: art. 673). Sin embargo, en el marco de la misma acción y recurriendo a la persuasión pacífica (Acosta s. j., 1577: cap. VIII, par: 3), los sacerdotes pudieron lograr, paulatinamente, la reducción de los mismos. Dice el padre Ruiz de Montoya:

La entrada a sus tierras no era para pelear, pues no llevábamos armas, ni menos quitarles oro o plata, que no la tenían, sino a solo hacerlos hijos de Dios y enseñarles el buen modo de vivir; no se rindieron tan fácilmente, pero al fin se rindieron a las persuasiones (Ruiz de Montoya s. j., -1640- 1989, p. 112).

La persuasión representó una alternativa eficaz, en contraposición a la acción militar de los españoles, para la reducción de los guaraníes. Esta fue promovida mediante el uso de la cruz, las imágenes y la música como instrumentos de sensibilización y seducción. A medida que los sacerdotes lograban la aglomeración de los guaraníes en los nuevos espacios, los dramas estéticos europeos -imágenes, música- fueron utilizados como canales de sensibilización, transmisión del discurso cristiano y como medios de enseñanza; tal como lo establecía el Tercer Concilio limense -1582/1583-, el cual manifestaba: "Id a las iglesias por las mañanas, allí haced oración cada día, sin faltar ninguno y también a las tardes, tomando agua bendita y besando la cruz y mirando las imágenes" (Tercer catecismo y exposición de la doctrina cristiana por sermones 1585: sermón XXVIII). Pero además de haber servido para exhibir y enseñar los símbolos cristianos, las manifestaciones estéticas fueron un medio para la adaptación y eliminación de determinados aspectos culturales de los guaraníes, como también un canal para reintegrar a la mayor cantidad de indígenas a la nueva configuración social.

Debido a ello, los sacerdotes diseñaron una política sociocultural a partir de la cual establecieron los talleres de artes y oficios, en los que pudieron crear espacios de participación activa de los guaraníes (Massoni y Pérez, 2009), a partir de las distintas prácticas de producción de los dramas estéticos. De esta manera, los jesuitas buscaban la "producción de un habitus" (Bourdieu, 2007, p. 86), conformado por estas rutinas de trabajo y la asistencia diaria a los ritos cristianos. Junto con ello, las actividades en estos talleres les permitieron a los curas imponer nuevos roles y jerarquías de poder para ejercer el control de policía (Foucault, 2011) y fortalecer sus vinculaciones con este sector social. 
Por lo expuesto, consideramos a los dramas estéticos en tanto performance como comunicación estratégica (Aguerre, 2015), ya que estas expresiones con características de entretenimiento se articularon con el drama social -prácticas rituales que fueron adaptadas, eliminadas o transformadas producto del encuentro entre ambas culturas- para promover mediante escenificaciones públicas una eficacia política; a partir de un diseño estratégico que comprendía acciones de sensibilización y participación para la reintegración de la comunidad guaraní en los espacios de reducción (Turner, 1987, 1988; Schechner, 2000, 2007). A través del uso del drama estético como aspecto constitutivo de la performance, los jesuitas apelaron a la sensibilización -considerada como un elemento de importancia para la Orden ignaciana ${ }^{1}$ - y la participación para crear trabajos comunitarios; roles; jerarquía de poder; producir emociones y motivar la apropiación de los valores cristianos y la identificación con ellos.

\section{Sonidos, música y canto/danza}

En los primeros encuentros, los sonidos y música actuaron como instrumentos de sensibilización y atracción de los guaraníes.

Los jesuitas, navegando por los ríos, echaron de ver que cuando para explayarse santamente cantaban cánticos espirituales acudían a oírlos tropas de indios y parecían tener en ello gusto especial. Aprovechándose de él para explicarles lo que cantaban; y como si tal melodía hubiera cambiado sus corazones, haciéndoles susceptibles de los afectos que les quería inspirar, no tenían dificultad en persuadirles a que los siguiesen, los hallaban dóciles y poco a poco hacían entrar en sus ánimos los grandes sentimientos de la religión. (Charlevoi II, 1912, p. 60, en Chamorro, 2004, p. 252)

Como lo señala el padre Cardiel, "cuando los primeros misioneros vieron que estos indios eran tan sensibles, pusieron especial cuidado en la música para atraerlos a Dios" (Cardiel s. j., -1747/1770-, 1994, p. 102). Esta predisposición de los guaraníes hacia los sonidos y la música estaba marcada por sus prácticas rituales en los cantos/danza. Estos eran el momento y lugar donde se estructuraban las funciones de los karai/chamanes, "donde los hombres se dicen y se vuelven dioses, donde se cantan las palabras inspiradas" (Meliá s. j., 1997, p. 128). La danza ritual y los cantos fueron la forma en que los guaraníes expresaban su religiosidad, pero también la manera en que las rebeliones indígenas afirmaban su identidad frente a las otras tribus (Chamorro, 2004).

Los guaraníes conformaban una sociedad de guerreros producto de un estado conflictivo entre grupos que se disputaban -en algunos casos- el mantenimiento de la legitimidad de los líderes y, en otros, el requerimiento de amplios territorios para la agricultura de siembra ${ }^{2}$. A través de la danza, el canto y el ñe 'e ayvu -traducido como palabra que denota voz, habla, lenguaje, idioma, alma, nombre, vida, personalidad, origen (Ruiz de Montoya s. j., 1640)-, los karai/chamanes podían manifestar sus mitos, realizar los rituales de nombramientos, conectarse con sus antepasados y manifestar -ante las tribus enemigas- su 
identidad de origen. "Muchos se ennoblecen con la elocuencia en el hablar, tanto estiman su lengua y con razón porque es digna de alabanza y de celebrarse entre los de fama con ella agregan gente y vasallos". (Ruiz de Montoya s. j., -1640- 1989, p. 149)

Tal como lo expresaba el padre Ruiz de Montoya en sus registros, las palabras cantadas eran de gran importancia en la comunidad guaraní, a tal punto que éstas actuaron como manifestaciones de resistencia por parte de sus líderes frente a los jesuitas como nos hace saber el padre Lozano en una de sus vínculos y contactos en una comunidad:

Oberá se tomó su tiempo en el camino hacia el Paraná, goza de placeres torpes. Mantuvo una multitud de concubinas con las que se ocupó en los bailes abominables y compuso canciones para su propia alabanza, y él persuadió a todos los demás de que si así desean permanecer en su favor, entonces deberían hacer lo mismo día y la noche. Ellos le obedecieron con prontitud, ya que la licencia para hacer el vicio es la más poderosa ayuda para reunir la obediencia entre los bárbaros. Todo el tiempo que no se dirigían a infestar Asunción pasaron a cantar alabanzas a su adorado Oberá, ensalzando su poder y majestad, y otros atributos que se atribuía en su orgullo diabólico. El peligro en la provincia creció por momentos debido a la comitiva y la potencia de Oberá, atrayendo indios de partes distantes a adorar esta fabulosa deidad. (Lozano s. j., 1874, pp. 21, 24)

Los jesuitas consideraban que debían eliminar a los karai/chamanes no sólo por ser los líderes religiosos sino porque mediante las palabras cantadas, éstos convocaban a sus tribus para impedir la transmisión de las nuevas ideas cristianas.

Cubierto con una capa de plumas que suenan las castañuelas hechas de cráneos de cabra y saltando como locos, él demandó que él era el verdadero señor de la muerte, de las mujeres y de los granos; que todo estaba sujeto a su voluntad, que con su aliento podría aniquilar el mundo y volver a crearlo, que él era un dios en tres personas, que a través de su ritual que había dado el ser a su esclavo. (cit. de Chicago-Córdoba, 1993, en Wilde, 2007, p. 51)

Según los sacerdotes, los karai/chamanes también ponían en riesgo la estabilidad de la vida en la misión. Como plantea el antropólogo Haubert (1991) en los ritos religiosos y guerreros, los karai/chamanes se apoderaban del cuerpo de uno de sus adversarios para comérselo como símbolo de dominación y legitimación de sus líderes.

La antropofagia no se trata sólo de saciar el hambre. El rito exige la reparación, el rapto de energía vital en el grupo victorioso a los que matan a un enemigo o le hacen prisionero, el que ejecuta al guerrero cautivo, los que comen de su carne o simplemente lo tocan, aunque sea con un palo. Los niños que abren el cráneo con pequeñas hachas de cobre y empapan sus manos en sangre, todos se engrandecen, adquieren fuerza y cambian el nombre. La antropofagia y la guerra tienen en si una función social esencial. (cit. de Haubert, 1991, p. 28, en Herraiz, 2006, p. 4) 
Así lo relata Ruiz de Montoya s. j., al pretender ingresar a la provincia de Tayaobá.

Dieron muestras de recibirme bien, pero fingidas, porque dado aviso de mi llegada, toda aquella noche fue desgalgando gente de aquellas sierras con ánimo de comerme y a los que iban en mi compañía. (...) El que más ardía en furor y deseos de comerme era un mago llamado Guirabera, el cual se hizo llamar Dios y con sus mentiras se había apoderado de esa gente. (Ruiz de Montoya s. j., $-1640-1989$, p. 123)

En lo que fuera la reducción de Loreto, también manifiesta que:

Salimos el P. José y yo por aquellos ríos a convidar a los indios a que se redujesen en poblaciones grandes, en puestos que ya se le habían señalado. Llegamos a un pueblo cuyo gobernador era un cacique, gran mago y hechicero y familiar amigo del demonio, llamado Taubici, que quiere decir, diablos en hilera o hilera de diablos. Era muy cruel y con cualquier achaque hacía matar indios a su antojo, y así era respetado y servido a pensamiento. (Ruiz de Montoya s. j., $-1640-1989$, p. 73 )

No sólo se pretendía erradicar la figura de los karai/chamanes sino que, además, tenían que re-significar los sonidos y las palabras cantadas, a partir de las cuales se constituía la identidad guaraní. A través de la observación y registro (Carballeda, 2008) de las prácticas guaraníes, Ruiz de Montoya s. j. describe cómo los "alaridos" eran utilizados frente a la muerte de un integrante de la comunidad guaraní.

Reciben a los huéspedes o a los que vienen de viaje con un formado llanto de voces. (...) Salen luego las dos mujeres y rodeando al huésped, sin haberse hablado palabra, levantan ellas un formal alarido. (...) Los varones cubren el rostro con las manos mostrando tristeza y llorando juntamente. Cuanto más importante es la persona, mayores son los alaridos que semejan que alguien muy querido de la comunidad ha muerto. (Ruiz de Montoya s. j., -1640- 1989, pp. 31, 32)

Los jesuitas captaron estos sonidos como signos de comunicación para re-significarlos en términos cristianos y para usarlos en determinados ritos religiosos. Un ejemplo de ello, lo presenta el padre Escadón cuando describe un funeral cristiano.

En el momento del entierro los monaguillos van por el difunto con el Padre, vestido con una capa de lluvia negra, y los músicos y, a partir de ahí, el cortejo fúnebre se ordena a la iglesia, en la que el elogio se canta, etc (...). Mientras que el cuerpo es puesto en el sepulcro, los gritos de la madre, esposa o parientes comienzan con un tipo de canto lúgubre que es tan disonante que es imposible de explicar. Esta canción o gemido, en su guahú lengua o lamentación, es cantado por las mujeres. En ella cantan, lloran o hablan sobre el fallecido diciendo 
no solo lo que era, pero lo que se esperaba que hubiera sido si no hubiera muerto. (Escadón s. j., -1769-, en Furlong s. j., 1965, p. 78)

A los sonidos guaraníes re-significados se les sumaron los impuestos por la religión cristiana. Los jesuitas recurrieron a la estimulación sensitiva, a través de las campanas y los tambores, para marcar el orden temporal en las rutinas diarias.

El sonido de las campanas y los tambores -los que se utilizaban para guiar a las poblaciones a través de diversas actividades y rituales diarios- hacía que los guaraníes supieran cuándo eran convocados para la misa, el trabajo, la comida, la confesión, la oración. (Singer, 2009, p. 47)

El padre Ruiz de Montoya refiere a cómo organizaban al pueblo para que asistiesen a la misa en los primeros tiempos de las reducciones: "padecíamos en una reducción un gran trabajo, que estando toda la semana hirviendo el pueblo de gente, solos los domingos cuando a voz de muchas campanas queríamos juntar el pueblo al sermón y Misa" (Ruiz de Montoya s. j., -1640-1989, p. 131). Mientras que el padre Cardiel nos ofrece información sobre esta disposición temporal hacia mediados del S. XVIII. (Ver Figuras 1 y 2)

A las 4 y media de la mañana se toca la campana de la torre a las Avemarías: a las 4 y media a oración mental. A las cinco y cuarto abre la puerta el portero para que entren los sacristanes y cocinero. A las 5 y media, a salir de oración con la campana chica de los padres, y con la de la torre a misa. (...) A las diez y cuarto a examen: después de comer, quiete o conversación, en que también se toca a salir. Siesta hasta las dos. A las dos se toca la campana grande. (...) A las cinco a rezar los muchachos y pregúntales la Doctrina un Padre: acabada ésta, toca la campana grande al rosario. (...) A las siete en verano y a las 8 en invierno se toca la campana para cenar. (Cardiel s. j., -1747/1770- 1994, p. 95)

"A la intuición meteorológica se contrapone, por lo tanto, el intervalo regular de la campanada litúrgica, cuyo orden es el principal gobierno de la Iglesia" (Valenzuela Márquez, 2001, p. 364). Como ya manifestamos, el sonido de las campanas convocaba a los guaraníes a las prácticas rituales y a las laborales pero, también, las mismas eran concebidas como expresión del poder de Dios.

Estaba yo por este tiempo en Loreto cubriendo un campanario, en que tenía una buena campana que su Majestad nos había dado; turbose un pensamiento de que un indio de los que trabajaban se hacía caer del campanario y morir sin confesión y quebrar la campana, me acogí al Santísimo Sacramento (que ya lo había colocado) y suplíquele que si algo de aquello había de suceder se refundiese todo en la campana, porque sentiría mucho ver un indio muerto sin confesión: esto fue sábado en la tarde; tocose varias veces la campana aquel día, y a la noche al Ave María y después a las ánimas; el día siguiente al primer toque que se dio con ellas sentimos quebrada: me consoló mucho su pérdida 


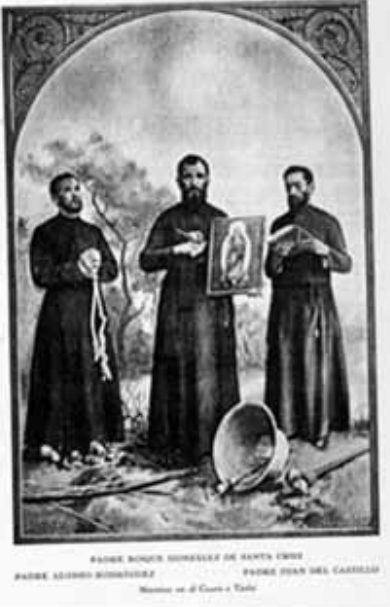

Figura 1.

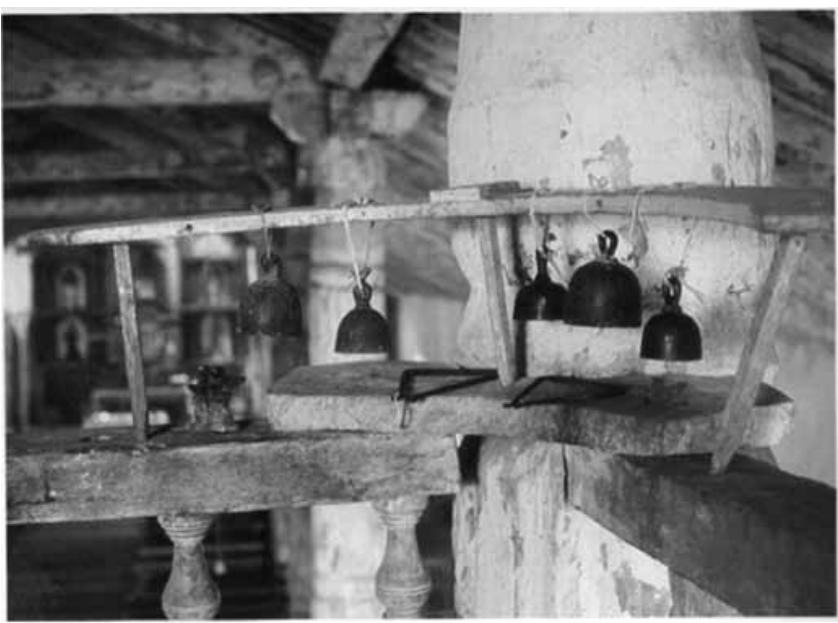

Figura 2.

Figura 1. Blanco, J. M (1929): “Jesuitas mártires del Caaró: Roque González de Santa Cruz, Alonso Rodríguez y Juan del Castillo". Ed. Amorrartu. Figura 2. Las pequeñas campanas de la aldea de Santa Ana, en la región de Chiquitos, Bolivia. Foto de: Szarán, Luis y Ruiz Nestosa, Jesús (1999): "Música en las reducciones jesuíticas de América del Sur". Asunción. Colección de Instrumentos de Chiquitos, Bolivia. Fundación Paracuaria, Missionsprojur S.J. Nürnberg, Centro de Estudios Paraguayos “Antonio Guasch".

por la ganancia del indio. Apenas habían pasado tres horas cuando el P. José me escribió de San Ignacio (que estaba tres leguas de Loreto) preguntándome si era verdad que estaba quebrada la campana, porque en amaneciendo se había aparecido el demonio a algunos indios, y les había dicho: Mirad mi poder, yo vengo ahora de quebrar la campana de Loreto. (Ruiz de Montoya s. j., -1640 1989, pp. 100, 101)

Este relato revela la importancia que se le otorgaba a este instrumento. Ruiz de Montoya s. j. "suplica" al Santísimo que quiebre la campana antes de que un guaraní pierda la vida. Para el padre, ella representaba un medio de manifestación de Dios -aunque creyeron que fue el "demonio", el que tuvo el poder de quebrarla-. Esto demuestra que la campana era un elemento usado como intermediario ante la divinidad; su sonido portaba una carga sagrada que marcaba el pulso vital del tiempo en el espacio misional recordando la presencia divina. 
La Iglesia confirmaba, de esta forma, un rol globalizador que apuntaba al control del universo mental de la comunidad en todos sus intersticios sensibles. Al lado de la palabra persuasiva, de la imagen y del ritual emotivo, el lenguaje de sus campanas sobrevolaba de día y de noche, recordando la omnipresencia de las fuerzas divinas y de sus interlocutores institucionales. (Valenzuela Márquez, 2001, p. 365)

El relato también nos muestra la circulación de información entre los sacerdotes en el espacio jesuítico-guaraní. Junto a las cartas Annuas -que los curas provinciales debían mandar al Prepósito General; es decir al Padre General de la Compañía en Roma-, también se producía correspondencia entre quienes estaban al frente de cada reducción para que éstas "ayuden a unir a los repartidos con su cabeza y entre sî" (Constituciones: art. 673).

Las cartas entre los sacerdotes del espacio jesuítico-guaraní, como las Annuas, refieren a situaciones en las que "la emisión del enunciado implica la realización de la acción" (Austin, 1955, p. 8). En estos textos performativos (Austin, 1955, p. 9) no se encuentra tan sólo la descripción de un hecho particular sino que se realiza la acción de tener que escribir un relato moralizante. Así lo expresa Ruiz de Montoya s. j., en relación al demonio: "mirad mi poder, yo vengo ahora de quebrar la campana de Loreto" (Ruiz de Montoya s. j., -16401989, p. 101).

Estos relatos entre los padres del espacio jesuítico-guaraní son destacables, en la medida que -y en función de ellas- éstos pudieron hacer "que todo funcione, por órdenes repetidas de los generales (...) y la continua práctica de avisos entre poblaciones" (Cardiel s. j., -1747/1770-1994, p. 88). De esta manera, podemos inferir que los jesuitas apelaron a estrategias comunes para la organización sociocultural de la vida en la misión, como lo demuestra el padre Cardiel en la cita siguiente, en relación a las prácticas musicales.

Todas las reducciones tienen 30 o 40 músicos. A los indios se les enseña desde la infancia y gracias a la perseverancia y la seriedad de la enseñanza, se convierten en músicos o cantantes calificados. He pasado por Europa y en pocas catedrales he escuchado una música mejor que éstos. (Cardiel s. j., -1747/17701994, p. 102)

La práctica musical -ejecución de instrumentos y cantos- y producción de objetos -en los talleres y escuelas de música-, también se constituía como momentos y espacios de control (Foucault 2011) mediante la vigilancia en los trabajos, la disciplina en la labor y el aprendizaje de los cantos como de los instrumentos.

Las performances musicales requerían de una participación activa -trabajo, educación musical $^{3}$ - y una contemplativa en los momentos de exhibición. Estas se realizaban en escenarios públicos - plazas y calles-, en función de las celebraciones religiosas o civiles, y en las iglesias en ocasión de las misas. "La música de todos los días en la iglesia que duraba mientras duraban las misas, es decir casi toda la mañana, repartida en dos coros uno frente al otro de modo que cesando uno recomenzaba el otro a su turno" (Strabel s. j. -1705-, en Furlong s. j., 1962, p. 491). 
Los jesuitas conformaron coros y orquestas e introdujeron instrumentos europeos -que fueron reproducidos por los guaraníes- para la representación de los dramas estéticos musicales impuestos por la Contrarreforma: himnos, villancicos, letanías, etc. Por los inventarios realizados durante el proceso de expulsión de los jesuitas, podemos conocer una notable cantidad de objetos musicales diferentes que fueron elaborados durante el período de convivencia (Furlong s. j., 1962, pp. 675, 690). También sabemos -por el relato de los padres-, que en la reducción de Yapeyú se estableció la escuela de música para los guaraníes. Dice el padre Furlong:

Yapeyú no solo llegó a ser un gran emporio musical, por la escuela musical que allí se fundó y a la que acudían hasta de las ciudades españolas, sino también por haber llegado a ser el gran taller de toda clase de instrumentos musicales, órganos, arpas, violines, trompas, cornetas, chirimías, y toda clase de instrumentos musicales que eran allí fabricados con singular destreza y exportados a las reducciones de indígenas y a las ciudades españolas. (Furlong s. j., 1962, p. 487)

Junto a la enseñanza de la música, los guaraníes también aprendieron las danzas europeas.

Por medio de maestros seglares se introdujo esta enseñanza en los indios y estos aprendieron tan bien, que ya sirven de maestros unos a otros. Y así en cada pueblo formase cuatro cuadrillas de a ocho danzantes que de ordinario son los mismos que aprenden la música. (Insignes misioneros de la Compañía de Jesús en la provincia del Paraguay. Pamplona 1687, p. 23, en Furlong s. j., 1962, p. 489).

A diferencia de la música -que era ejecutada todos los días-, las danzas sólo se realizaban los domingos y en las festividades o procesiones religiosas y civiles.

No menos atraen las danzas de los niños a los grandes a la iglesia, teniendo por suma dicha de sus hijos el verlos galancitos danzar en las festividades y procesiones con raro primar. Porque un niño de ocho años hará 50 mudanzas sin perder el compás de la vigüela o harpa, con tanto aire como el español más ligero. (Jarque s. j., -1662-, en Furlong s. j., 1962, p. 489)

Con esta descripción notamos que la performance responde a un drama español -reglas de composición- que, en función de una puesta en escena, fue exhibido en el espacio de la iglesia donde los niños ejecutaron "50 mudanzas sin perder el compás de la vigüela o harpa"; es decir, teniendo una disciplina en la destreza de la danza y, por ende, en el dominio del cuerpo que a su vez representaba el concepto de persona cristiana. "Las reglas y normas de comportamiento religioso son prácticas de control del cuerpo y, en este sentido y dentro del horizonte americano colonial, funcionaron como mecanismos de interiorización de los fundamentos filosóficos, morales y éticos”. (Araya Espinosa, 2006, p. 349) 
Pero además de interiorizar a la persona cristiana, el cuerpo debía representar el ideal civil español.

Salen en una danza doce danzantes chicos y grandes, todos con instrumentos musicales, danzando y tocando a un tiempo, sin que los músicos les hagan el son. Los dos primeros con violines y vestidos de españoles mientras los segundos con pequeñas arpas amarradas con cintas a la cintura. (Cardiel s. j. -1770-, en Furlong s. j., 1962, p. 489)

En este sentido, la performance operó desde el drama estético hacia el drama social, en tanto que su exhibición no representaba "simplemente un hacer sino un mostrar que se hace" (Schechner, 2000, p. 21). A partir de la elección de los danzantes y de la enseñanza y repetición de las figuras de baile -ensayo-, los jesuitas transformaron las conductas y los modos de actuación -restauración de la conducta (Schechner, 2000, p. 109)-. Así, los danzantes/actores comunicaban a los miembros de la comunidad/espectadores bajo qué formas debían actuar en sus vidas cotidianas y qué valores debían adoptar, en virtud de los personajes que en ellas se representaban. El padre Matías Strabel nos brinda otro ejemplo:

Ellos mismos tocaban y bailaban al mismo tiempo, pero con tal rigor en la cadencia y con tal orden y control en las figuras, que se ganaban el aplauso y la aprobación de todos. Lo mismo era con todas las otras danzas, en las cuales lo más admirable, a mi parecer, era aquella exactitud del tiempo y del orden, si errar un ápice por más largos que fuesen y aunque los bailasen, a veces, 16 o 24 veces. (Strabel s. j., -1705-, en Furlong s. j., 1962, p. 491)

En esta performance se puede observar la eficacia de la conducta restaurada (Schechner, 2000), realizada a través de la repetición/ensayo del drama: "con tal orden y control de las figuras que se ganaban el aplauso y la aprobación de todos". Igualmente, estas exhibiciones no dejaban de ser una dispersión: "todas estas cosas sirven para honesto entretenimiento en sus pueblos para que por los ojos y con decente deleite del alma y cuerpo les entre las cosas de Dios" (Cardiel s. j., -1770-, en Hernández s. j., 1913, p. 534). Un entretenimiento que provocaba sensibilización y la propensión a pautas morales, a partir de los temas danzados.

Hay también variedad de danzas de ángeles y de ángeles y diablos con el traje correspondiente, peleando unos con otros; y otras en que trayendo cada uno tableta en la mano pintada y poniéndola cada uno sobre una mesa, una sobre otra, tras cada mudanza representan al fin una perfecta imagen de la Virgen María, de San Ignacio o de otros. (Cardiel s. j., -1770-, en Hernández s. j., 1913, p. 535)

Apelando al estímulo sensorial -danza, imágenes- la estructura dramática de esta performance incorporó el conflicto entre los ángeles y el diablo para transmitir los conceptos de bien y mal cristiano, y reafirmar un modelo identitario de conducta que se consolidaba y se distinguía de otro. 
A diferencia de las performances de la imaginería (Aguerre, 2015), la representación de la música y la danza no presentaba roles jerarquizados de poder. "Las producciones sonoras eran concebidas de formas abiertas, flexibles y plurales" (Wilde, 2007, p. 1). Por ello, a partir de la sensibilización -provocada por los sonidos y la música- y la participación trabajo, ensayos, puestas en escena/público- como estrategias de comunicación (Massoni y Pérez, 2009) de la performance, se orientó a la acción de re-significación y apropiación de un tipo identitario de conducta y alteridades.

Ante lo expuesto, podemos afirmar que los cantos/danzas guaraníes fueron transformados de hábitos rituales a prácticas singulares que, si bien se desarrollaban en los nuevos ritos cristianos, permitieron la integración de los guaraníes a las rutinas diarias mediante la conformación de escuelas, grupos instrumentales, corales y de bailes. De este modo, la música y los bailes posibilitaron la creación de espacios para la producción, aprendizaje y ensayos, y la participación de los guaraníes que, enmarcados en una misma actividad, permitían generar la sensación de pertenencia y permanencia hacia ese colectivo.

La eficacia de estas performances musicales puede evidenciarse por los relatos realizados luego de la expulsión de los jesuitas, en los cuales se manifiesta que la música siguió siendo ejecutada por los descendientes de los guaraníes. Por el obispo diocesano Monseñor Sebastian Díaz Larangiera, sabemos que en el pueblo de San Luis -hacia 1864- los guaraníes continuaron celebrando la Semana Santa entonando -en su lengua- algunos cantos. Sorprendido al ver que sus descendientes de aquellos indios civilizados por los jesuitas desterrados hacía una centuria, conservaban las mismas tradiciones musicales enseñadas por sus maestros y así todo el canto de la Semana Santa era en guaraní, Hemeterio Velloso da Silveira, que los oyó cantar, tomó nota de esos cantos.

\begin{tabular}{|l|l|}
\hline Cristo Señor Nuestro & Cristo Nhandejara, comi borara acuerá y \\
Líbranos Señor & quatia picera \\
De nuestro pecado & Nhamdemoñaangara \\
Perdónanos, Cristo Señor Nuestro (bis) & Ah! Cristo nhandejara (bis) \\
Por las antorchas con que te buscaron & Conde quarepotyyocua acuerá \\
Los crueles judíos & Nhamdemoñaangara yocuá pirera \\
Por nuestros pecados & Ah Cristo nhandejara \\
Perdónanos, Cristo Nuestro Señor & Conde, tatahende, heca heca acuerá \\
Por la espada & Nhamdemoñaangara heca heca pierá \\
Con la cual, San Pedro & Ah! Cristo, nhandejara". \\
Pretendió defenderte & \\
De los crueles judíos & \\
Perdónanos, Cristo Nuestros Señor. & \\
\hline
\end{tabular}

(Velloso da Silveira 1864, en Furlong s. j., 1962:. 489). 


\section{Conclusión}

La intervención social jesuítica delineó un diseño estratégico en su labor evangelizadora produciendo el conocimiento de los elementos socioculturales de los pueblos guaraníes a intervenir. Esto les facilitó a los sacerdotes la elección de acciones para viabilizar el diálogo y las relaciones entre los actores comprometidos (Acosta s. j., 1577; Carballeda, 2008), en virtud de la transformación de determinados principios sistémicos de la comunidad -nociones de identidad, alteridad, roles y jerarquías de poder-, los cuales colaboraron en el establecimiento y sostenibilidad del orden sociopolítico impuesto.

Por lo expuesto, consideramos que las performances musicales fueron utilizadas como un instrumento de diseño comunicacional estratégico para lograr la interacción entre los actores comprometidos como también para bridar forma al proceso social de intervención. Es así que a partir de la información obtenida de la comunidad guaraní y de las puestas en escena rituales, los jesuitas pudieron transmitir y marcar los nuevos modos de vinculación con el cuerpo, con el trabajo, con la noción de alteridad, con las ideas y creencias mitológicas y con los estatutos y roles de poder mediante las estrategias de sensibilización y participación comunitaria.

Debido a ello, es que entendemos a la performance como un instrumento de diseño político y práctica comunicativa donde los sentidos y significaciones de cada cultura interactúan, pero también manifiestan sus luchas simbólicas -materializadas en la tensión sujeto cristiano/ser guaraní-, generando cambios sistémicos y proactivos en la dinámica sociocultural de los grupos comprometidos en este proceso de intervención social.

\section{Notas}

1. Ver 1ra. anotación de los Ejercicios Espirituales. Versión digital, en: www.ejercicioses pirituales.com

2. La rotación de los cultivos imponía una forma de ocupar el espacio que permitía mantener el equilibro entre la población y los recursos. "La tierra origina ciclos que no son solo económicos sino socio-políticos y religiosos" (Chamorro, 2004, p. 65). Es probable que esa consciencia de la dependencia de la tierra esté en la base de las celebraciones del maíz nuevo, de los frutos maduros y de la revelación del nombre (Clastres, 2007).

3. Uno de los primeros maestros de música que llegó al espacio jesuítico-guaraní fue el padre Juan Vaisseau (1583-1623), natural de Bélgica donde había trabajado como músico profesional. Arribó a Paraguay en 1617, dejando el cargo de músico oficial de la corte de Carlos V. Junto con él, Luis Berger (1589) -que no era sólo un músico, sino también pintor y maestro de baile- y el padre Antonio Sepp (1691) se dedicaron a la enseñanza musical.

\section{Referencias Bibliográficas}

Acosta, J. de s. j. (1577). De Procuranda Inorum Salute. Recuperado de: www.cervantesvirtual. com/predicacion-del-evangelio indias. 
Araya Espinoza, A. (2006). El castigo físico. El cuerpo como representación de la persona, un capítulo en la historia de la occidentalización de América S. XVII-S. XVIII. Santiago de Chile, Chile. Revista de Historia Vol 2. (No 39), pp. 20, 25 Instituto de Historia Pontificia. Universidad Católica de Chile.

Austin, J. (1955). Cómo hacer cosas con palabras. Barcelona: Paidos Ibérica.

Blanco, J. M. (1929). Historia documentada de la vida y gloriosa muerte de los padres Roque González de Santa Cruz, Alonso Domínguez y Juan del Castillo. Buenos Aires, Argentina: Ed. Amorrortu.

Carballeda, A. (2008). Los cuerpos fragmentados. Buenos Aires, Argentina: Ed. Paidós.

Chamorro, G. (2004). Teología guaraní. Recuperado de: www.books.google.com

El Concilio de Trento. Recuperado de: www.books.google.com

Constituciones De La Compañía De Jesús. Recuperado de: www.bib.cervantesvirtual.com

Furlong, G. s. j. (1962). Misiones y pueblos guaranies. Buenos Aires, Argentina: Ed. Biblioteca del Colegio El Salvador.

Massoni, S. y Perez, R. (2009). Hacia una teoría general de la estrategia. Buenos Aires, Argentina: Ed. Ariel Comunicación.

Herraiz Labrador, C. (2006). Las reducciones del Paraguay. Madrid, España. Recuperado de: www.dialnetunrioja.es

Lozano, P. s. j. (1874). Historia de la Conquista del Paraguay, Río de la Plata y Tucumán. Recuperado de: www.eBooks and Texts. American Libraries/archive.org

Ruiz De Montoya, A. s. j. (-1560/1570-1991). "Silex del Divino amor". Lima, Perú: Ed. Pontificia de la Universidad Católica.

Ruiz De Montoya, A. s. j. (-1640- 1989). "La Conquista espiritual del Paraguay”. Rosario, Santa Fe: Ed. Equipo Difusor de Estudios de Historia Iberoamericana.

Schechner, R. (2007). "Performance theory". New York, USA: Ed. Routledge.

Sebastian, S. (1985). “Contrarreforma y barroco”. Buenos Aires, Argentina: Ed. Alianza Forma.

Sepp, A. s. j. (-1691/1733-1971). "Relación de viaje a las misiones jesuíticas”. Buenos Aires, Argentina: Ed. Eudeba.

Sepp, A. s. j. (-1709-1973). “Continuación de las labores apostólicas”. Buenos Aires, Argentina: Ed. Eudeba.

Turner, V. (1987). From ritual to theatre. New York, USA: Ed. Performing Arts Journal Press.

Turner, V. (1988). The Anthropology of Performance. New York, USA: Ed. The Performance Arts Journal Press.

Wilde, G. (2007). Music and polities. Toward and political anthropology of mision sound: Paraguay in the 17th and 18th centurias. Recuperado de: www.music.ucs.lo.edu

Wilde, G. (2009 -a-). Religión y poder en las misiones de guaranies. Buenos Aires, Argentina: Ed. Paradigma Indicial.

Wilde, G. (2009 -b-). Imágenes, sonidos y memoria. Hacia una antropología del arte misional. in Histoire de l'art et anthropologie, Paris, coédition INHA / musée du quai Branly ( Les actes »), 2009, [En ligne], mis en ligne le 28 juillet 2009, Consulté le 31 août 2017. URL : http://actesbranly.revues.org/316. 


\begin{abstract}
This article will attempt to explain how music, sounds and singing/dancing used by the jesuits along the process of social intervention of argentinian guarani communities during the Spanish Conquest in order to remove and re-significate guarani rituals habits and adapt them to christian mood. We will investigate the first encounters between the two groups to observe how those priests used music as a means to prompt guarani sensitiveness which would allow the jesuits reduce the guarani. We shall then observe how, after the constitution of these reductions guarani, sounds and singing/dancing were resignificated ant them, to what extent these christian aesthetic musical drama allowed the jesuits the creation of actions where the guarani could internalize new behavious, habits and sensibilities. For the analysis we shall use the category of performance as a strategic communication (Aguerre, 2015) defined as the public scenification of aesthetic drama within a process of cultural and social design where sensitiveness and participation were strategic actions for social transformation (Massoni y Pérez, 2009).
\end{abstract}

Key words: music - performance - strategic communication.

Resumo: Este artigo irá expor como música, sons e canto / dança foram usados pelos jesuítas no processo de envolvimento social das comunidades Guarani-da actual território argentino durante a conquista espanhola para a remoção e re-significação de rituais e hábitos Guarani adaptação de comportamentos e atitudes, em um cristão. Vamos investigar nas primeiras reuniões entre esses grupos para ver como os sacerdotes tomaram a música com o objetivo de provocar uma espécie de consciência de que lhes permitiria reduzir o Guarani. Observe como a partir da constituição das reduções, sons e cantando / dançando Guarani foram e-significados re até que ponto dramas estéticas musicais cristãos permitiu a criação de oportunidades de participação que levou à internalização de novos comportamentos e sensibilidades. Para a análise vai usar a categoria de desempenho como comunicação estratégica (Aguerre, 2015), entendido como a encenação pública de dramas estéticos dentro de um processo de reintegração social (Turner, 1987), onde a consciência ea participação agiu como ações estratégicas para a transformação social (Massoni y Perez, 2009).

Palavras chave: música - performance - comunicação estratégica. 


\section{Arte y Transformación social. El aporte de artistas (circenses) en el diseño de políticas culturales urbanas}

Julieta Infantino*

Resumen: En el marco de una diversificación y pluralización del campo de las políticas culturales, desde los años 1990 aunque con mayor intensidad en los 2000 en el contexto Latinoamericano, comienza a desarrollarse un área de propuestas, acciones y políticas culturales que postulan al arte como estrategia para la transformación social. Dicha área se gestó, en gran medida, desde propuestas de colectivos artísticos y experiencias comunitarias que fueron resignificando el "rol social" del arte y las potencialidades del mismo para desarrollar políticas culturales inclusivas. Desde las mismas se propone luchar contra la segregación urbana, la estigmatización de grupos vulnerables y la desigualdad de oportunidades de acceso y participación en la cultura y las artes en el marco de un paradigma de democracia participativa que aboga por la ampliación de derechos (culturales).

En este trabajo propongo analizar el rol de artistas (circenses) -conformados ahora en organizaciones de la sociedad civil y devenidos en activistas, diseñadores/gestores/trabajadores culturales-, en la proposición crítica de alternativas ante paradigmas que han caracterizado a las políticas culturales. Estos paradigmas han instalado, entre otros aspectos, a la cultura como "recurso" para luchar contra los efectos indeseados del neoliberalismo promoviendo la gestión del riesgo social atribuido frecuentemente a los jóvenes pobres urbanos. La intención es analizar opciones que se enfrentan a esta retórica de control de las poblaciones afectadas por el desarrollo neoliberal a través del arte y la cultura y que pregonan el diseño de estrategias redistributivas, ancladas en un paradigma de derechos, que disputen inequidades y garanticen igualdad en el acceso, participación y producción cultural urbana.

Palabras clave: políticas culturales - campo arte-transformador - participación social diseño de políticas - arte circense.

[Resúmenes en inglés y portugués en las páginas 90-91]

${ }^{(*)}$ Profesora y Licenciada en Ciencias Antropológicas por la Universidad de Buenos Aires y Doctora con orientación en Ciencias Antropológicas por la misma Universidad (2012), en la que también se desempeña como docente. Es Investigadora Asistente del Consejo Nacional de Investigaciones Científicas y Técnicas (CONICET). Pertenece a diversos Equipos de Investigación vinculados al estudio de la cultura popular, el folklore, el patrimonio así como a la cuestión juvenil y la antropología urbana. Ha publicado libros, compilaciones y artículos en revistas académicas nacionales e internacionales y se especializa en el estudio de las relaciones entre Juventudes, Artes y Políticas Culturales. 


\section{Presentación}

¿Qué pensamos cuando nos referimos a las políticas culturales? ¿Hablamos en plural o en singular, arrastrando viejas concepciones vinculadas a un sentido restringido de cultura y a un modelo estado-céntrico? ¿Qué actores sociales están involucrados en el campo de las políticas culturales? ¿Las políticas culturales son las acciones que diseña e implementa un Estado para fomentar el desarrollo de "la cultura"? O, más bien, retomando a García Canclini en su ya clásica definición ¿las políticas culturales son

El conjunto de intervenciones realizadas por el Estado, las instituciones civiles y los grupos comunitarios organizados a fin de orientar el desarrollo simbólico, satisfacer las necesidades culturales de la población y obtener consenso para un tipo de orden o de transformación social? (García Canclini, 1987, p. 26)

Y en este sentido ¿cómo se disputan sentidos diferenciales de cultura y políticas culturales entre los diversos actores involucrados en su diseño, implementación y uso?

Este conjunto de interrogantes llevan a atender al terreno de las políticas culturales como una arena de negociaciones y disputa en la que, entre otras cuestiones, se debaten los sentidos atribuidos a ciertos conceptos clave vinculados al de Cultura como Desarrollo, Inclusión, Transformación social, Derechos (culturales). En esta línea, podemos ubicar el desarrollo de un conjunto de prácticas particulares que vinculan arte e intervención social/comunitaria. Las mismas se presentan como un campo emergente compuesto por un conjunto de agentes e instituciones - desde agencias estatales, organizaciones no gubernamentales, organizaciones sociales formalmente constituidas o agrupaciones informalesque impulsan múltiples iniciativas de promoción de disciplinas artísticas como teatro, circo, orquestas infanto-juveniles, danzas, fotografía, video o artes plásticas, entre otras. Dichas iniciativas suelen estar mayormente destinadas al trabajo con jóvenes que habitan contextos precarizados (Infantino, 2016a).

Si bien estos usos del arte para la transformación social no son nuevos -podemos encontrar antecedentes como mínimo desde los años 1960 en los vínculos entre movimientos sociales, asociaciones de base, militancia, activismo, arte y política- los mismos adquieren una dimensión particular y ciertas especificidades en un proceso que comenzó a marcar el terreno de la cultura y sus políticas desde los años 1980. En este nuevo escenario se asiste a una ampliación del concepto de "política cultural" que dejó de ser tomada en su sentido restringido y elitista -como un instrumento para ofrecer servicios y acceso a "la cultura" o para proteger "el patrimonio"- pasando a acentuar su carácter plural (García Canclini, 1987). Así, "las políticas culturales" fueron pensadas como herramientas con múltiples fines y en las que intervienen una diversidad de agentes que apelan desde distintos sentidos y desiguales condiciones de poder a "la cultura".

En esta dirección, los abordajes conceptuales contemporáneos de las políticas culturales las conciben en un sentido amplio,

No sólo teniendo en cuenta el rol ejercido por las instituciones estatales y las acciones gubernamentales en el desempeño de estas políticas, sino que incor- 
poran tanto las prácticas y formas de producción realizadas por agentes no estatales como a los destinatarios de éstas. (Crespo et. al., 2015, p. 9)

Desde esta definición amplia de políticas culturales propongo entender y atender al aporte que vienen realizando diversos colectivos artísticos al diseño e implementación de una direccionalidad particular en el campo cultural. Fundamentalmente, este tipo de propuestas trascienden una visión economicista y mercantilizada del desarrollo y de la cultura buscando promover estrategias redistributivas que disputen inequidades y garanticen igualdad en el acceso, participación y producción cultural urbana.

Sostengo entonces que lo que hemos conceptualizado como campo arte-transformador ${ }^{1}$ se presenta como un interesante espacio para analizar diversos modos en los que las políticas se diseñan, gestionan y negocian en un complejo entramado en el que los distintos agentes involucrados articulan y disputan -claramente, de modo asimétrico- intereses, recursos y poder, así como sentidos diferenciales del para qué del arte y la cultura. En este sentido, uno de los propósitos generales de este trabajo pretende comprender el lugar actual que ocupan unas estrategias particulares de acercarse a la práctica artística y a la intervención social/comunitaria en vínculo a ideas de cambio y transformación social, pensando a estas prácticas insertas en el campo de las políticas culturales, como una línea específica de desarrollo de las mismas que ha sido escasamente analizada como tal (Infantino, 2016a).

Para dicho propósito, organizaré este artículo con un primer apartado en el que pretendo analizar el proceso por el cual se fue consolidando, para finales de los años 1990, la mirada hacia la cultura y su valoración como recurso para el desarrollo (Yúdice, 2002) desde un uso puramente instrumental y utilitario. Aquí se ponderaron los posibles réditos económicos que la cultura traería aparejados como paliativo ante las situaciones de crisis producidas por el modelo neoliberal. El arte y la cultura se erigen como solución -casi mágica- para desarrollar territorios, generar empleos y para incluir, empoderar, reeducar y/o controlar a los sectores empobrecidos frecuentemente aportando una aproximación que oculta y simplifica las desigualdades estructurales de nuestras sociedades (Yúdice, 2002, 2008; Bayardo-Lacarrieu, 1999; Kliksberg, 1999).

En un segundo apartado, estudiaré ciertas propuestas emergentes que disputan, se apropian y resignifican el discurso de la cultura como recurso, a partir del caso concreto de una organización social que trabaja desde las artes circenses con jóvenes vulnerabilizados en el marco de propuestas arte-transformadoras. Circo del Sur es una Asociación Civil sin fines de lucro con una trayectoria de más de 20 años en el trabajo arte-transformador desde el circo en barrios precarizados de la ciudad de Buenos Aires. Busca la transformación social, personal y comunitaria a través de las artes circenses y combinadas. Su trabajo se orienta a fomentar espacios artísticos y socio-productivos con jóvenes en situación de vulnerabilidad social que habilitan el desarrollo autónomo y creativo de los participantes, su capacidad crítica y oportunidades más igualitarias de acceso a la formación y producción artística.

En este artículo propongo retomar algunas reflexiones y ejes de análisis de sus experiencias y propuestas de acción tomando datos de un trabajo de campo que vengo realizando en los últimos años y que recupera un vínculo sostenido desde 2008 con esta organización 
pionera en este tipo de estrategias en Argentina². El objetivo será estudiar diversas maneras en las que esta organización promueve propuestas que no solo se preocupan por las posibilidades de desarrollo/crecimiento (económico) a través del arte o por el "control" de las poblaciones afectadas por el desarrollo neoliberal -los jóvenes frecuentemente estigmatizados como en riesgo/riesgosos- sino más bien por diseñar estrategias redistributivas que disputen inequidades y garanticen igualdad en el derecho a acceder y participar en la vida cultural urbana.

\title{
De las Políticas culturales al impacto económico y social de la cultura
}

\author{
Las nuevas políticas culturales van más allá de disciplinar o \\ normar a los ciudadanos -según el análisis foucaultiano extendido a \\ las políticas culturales por Tony Bennett y otros estudiosos \\ angloaustralianos- y se convierten en políticas económicas.
}

(Yúdice, 2008, p. 50)

El proceso por el cual la justificación de la inversión pública en la cultura y las artes se asentó primero en criterios de rédito económico durante los años 1980 y luego en los posibles efectos sociales que la cultura y las artes traerían como solución a problemáticas de índole social en los 1990, se presenta como un proceso central para pensar al campo arte-transformador.

Aquí resulta de interés el análisis desarrollado por Eleonora Belfiore (2002) en el cual se propone atender a este proceso de justificación de la inversión pública en las artes en función del rédito económico durante la neoliberal Inglaterra de los 1980. En dicho contexto se debatía la responsabilidad del Estado en la preservación, difusión y promoción de "la cultura", centralmente desde una política que se proponía reducir el gasto público y engrosar el sector privado. Asimismo se asistía a una revisión de los lineamientos que habían caracterizado a las políticas culturales desde los años de la post guerra, destinadas a garantizar el "acceso" y la "excelencia", llevando "alta cultura" a la gente para "beneficiarla" (Belfiore, 2002) y, agregaría, para "civilizarla”. Esa actitud paternalista y elitista ya no era aceptable en los nuevos tiempos, por lo cual:

En este nuevo clima de incertidumbre acerca de los futuros niveles de gasto público, se creyó al interior del mundo del arte que, en función de sobrevivir, el arte necesitaba argumentar de manera sólida en contra de mayores reducciones en los financiamientos. (Belfiore, 2002, p. 94 [mi traducción])

Así comenzó a asentarse el énfasis en los aspectos económicos del arte y sus contribuciones al bienestar y el desarrollo de las ciudades. Este corrimiento del sector artístico hacia el lenguaje económico/empresarial, que se plasma en cambios semánticos -ya no se habla de "producciones" artísticas sino de "productos", las "audiencias" pasan a ser "consumidores", los "subsidios" pasan a concebirse como "inversiones"- en sus orígenes debe ser visto como una estrategia de supervivencia de los propios artistas en la que se buscaba 
"hablar el mismo lenguaje que el gobierno" (Belfiore, 2002). Sin embargo, este pasaje va a ir instalando una nueva racionalidad en las políticas culturales, reforzada por estudios cuantitativos que intentan relevar el impacto económico de las artes en términos de creación de empleos, promoción turística y regeneración urbana.

Lo interesante del planteo de la autora para nuestro caso de estudio se vincula a su argumento en relación a la característica que se sumará en los años 1990 en relación a la justificación de la inversión pública en el arte como instrumento para fomentar la inclusión social. Belfiore sostiene que la oleada de proyectos de inversión inspirados en "regenerar" las antiguas ciudades industriales europeas y convertirlas en "ciudades creativas"3 a partir de mejorar la imagen urbana evidenciaron notables fracasos y comenzaron a ser criticados, siguiendo a David Harvey (1989), como una "máscara carnavalesca" usada por políticos locales y nacionales para encubrir persistentes inequidades en el crecimiento económico y notables desigualdades sociales (Belfiore, 2002; Yúdice, 2008).

En consonancia con estos fracasos y en relación con un nuevo interés por mejorar la calidad de vida de las personas, las dimensiones sociales de la regeneración urbana se convirtieron en un nuevo foco de atención, en Inglaterra y en la Comunidad Europea. Aquí, dirá la autora, se añade un nuevo elemento vinculado a la proliferación de la inversión pública en las artes desde agencias estatales no específicamente artísticas -provenientes del sector de salud o de servicios sociales, entre otros- menos preocupadas por consideraciones estéticas o económicas y ponderando el impacto social del arte. En función de este recorrido sobre la política cultural inglesa (y, en cierta medida extensible a Europa) Belfiore concluye que:

A pesar de la retórica de los organismos de financiación (en torno a las palabras clave de la participación, empoderamiento, cohesión social, crecimiento personal y comunitario, que recuerda a los debates de los años setenta sobre democracia cultural), las políticas actuales en el ámbito cultural son la derivación de las teorías instrumentales de la cultura que dominaron el debate político en los años ochenta. (Belfiore, 2002, p. 97 [mi traducción])

Si ahora movemos el foco hacia Latinoamérica en los años 1990 post Consenso de Washington ${ }^{4}$, nos encontraremos con que luego de una nueva crisis cíclica del capitalismo crisis de acumulación de capital- organismos financieros internacionales, como el Banco Mundial y el Fondo Monetario Internacional, comenzaron a lanzar sus programas de ajuste estructural que integraban diversas áreas de reforma política (Murillo, 2006). Aquí comienza a diagnosticarse como motivo central del "retraso" o "subdesarrollo" de los países pobres ya no sus "falencias culturales" y su falta de infraestructura -al estilo en el que se había argumentado a partir de la "teoría de la modernización” desde los años 1940 (Balazote, 2007)-, sino al "excesivo crecimiento" de las instituciones estatales. En consecuencia, en América Latina se abandonan las estrategias de desarrollo propias de las décadas anteriores para volcarse definitivamente hacia tendencias neoliberales.

En este contexto, en términos de políticas culturales, comienza a virar el tipo de justificación de la inversión pública en la cultura y las artes. En sintonía con el clima de época, la reducción de las funciones del Estado en materia de garantización de derechos, se conver- 
tirá en discurso hegemónico. Si bien, siguiendo a García Canclini (1987), la privatización neoconservadora de la cultura ya traía un recorrido desde los años 1970, para fines de los años 80', que es el contexto en el que está escribiendo, ya se podía observar lo que en la década neoliberal por excelencia se agudizaría en distintos países de la región y particularmente en Argentina.

Hoy la tendencia dominante en las políticas culturales es el desplazamiento de la acción estatal a la producción y apropiación privada de los bienes simbólicos (...). La reducción de los fondos públicos y las exigencias de productividad impuestas por la tecnocracia monetarista en todas las áreas, lleva a los Estados a reducir las acciones "no rentables" y los eventos que "no se autofinancien" (el teatro, la música y las artes plásticas, especialmente sus líneas experimentales) y concentra la política cultural en la promoción de grandes espectáculos de interés masivo. (García Canclini, 1987, p. 45)

La reducción del gasto público que resaltaba García Canclini implicó no solo la valoración de la cultura en términos "rentables", sino que al igual que en Inglaterra y Europa, derivó unos años después en una justificación instrumental del recurso de la cultura en función de aportar soluciones a las consecuencias del modelo neoliberal impuesto en la región. Durante los años 1990 se expanden las estrategias promovidas por los discursos de los organismos internacionales tendientes a fomentar el "empoderamiento" de distintos actores sociales a través de "la cultura" como herramienta de lucha contra los efectos pauperizantes del desarrollo económico neoliberal, las reformas del Estado y el avance del mercado. El incremento de la violencia, la inseguridad y el "riesgo social" son apreciados como consecuencia de la fragmentación de los lazos sociales, de la debilidad de las instituciones en tanto agentes excluyentes y, finalmente, de la falta de participación de los sujetos. Siguiendo el análisis propuesto por Susana Murillo, para el Banco Mundial, por ejemplo, la "desigualdad" es objeto de preocupación ya que impide la reducción de la pobreza y esta última implica un riesgo social que debe ser "gestionado". La "gestión del riesgo social" consiste en elaborar las estrategias adecuadas para su prevención, mitigación y manejo, a fin de que su impacto sea mínimo (Murillo, 2006).

En efecto, la conversión de las políticas culturales en políticas económicas y sociales se agudizará en los años 2000, colocando a la cultura como "la solución" para enfrentar los efectos del neoliberalismo, ya sea desde un discurso de inclusión -contención, asistencia, prevención, control- de las poblaciones vulnerables como desde los beneficios económicos que la creatividad, la cultura y el arte traerían aparejados para las cada vez más desiguales ciudades del mundo. En definitiva, impacto económico e impacto social del arte y la cultura se erigen como dos dimensiones desde las que se intentan resignificar las estrategias de desarrollo (Kliksberg, 1999). En dicha resignificación diversas agencias internacionales -desde la Unión Europea, el Banco Mundial (BM), el Banco Interamericano de Desarrollo (BID) y las principales fundaciones internacionales-, comenzaron a percibir que la cultura constituía una esfera crucial para la inversión. Tal como señala Yúdice, apropiándose de una retórica "holística del desarrollo", propondrán utilizar el recurso de la cultura para promover la capacidad de acción o empoderamiento de los pobres, de ma- 
nera que puedan contar con los recursos sociales y humanos que les permitan soportar "el trauma y la pérdida", detener la "desconexión social", "mantener la autoestima" y a la vez generar recursos materiales (Yúdice, 2002).

Muchas de las propuestas arte transformadores como la que analizaré específicamente a continuación, surgen y/o se afianzan en el contexto de época que recorrí y se vieron influenciadas por los discursos que fueron instalando la instrumentalidad de la cultura para el desarrollo económico de las ciudades y la inclusión (control/gestión) de los sectores desfavorecidos - pobres, y sobre todo, jóvenes. No obstante, de modos complejos y no sin conflictos fueron luchando por sostener otras modalidades de pensar las propuestas socio-artísticas que disputen su mera instrumentalidad.

\section{La experiencia de Circo del Sur como aporte para el diseño de políticas culturales urbanas}

\section{a. La trayectoria de una organización socio-artística}

Si recorremos la trayectoria de Circo del Sur y las estrategias creativas que fueron desarrollando para sostener y multiplicar sus actividades a lo largo de sus más de 20 años de trabajo, nos encontramos con que en líneas generales desde sus prácticas ha disputado algunos de los paradigmas hegemónicos que recorrimos en el apartado anterior. En la experiencia de Circo del Sur como caso paradigmático dentro del campo del arte circense, pero que también podría hacerse extensivo a diversas propuestas del campo arte-transformador, podemos apreciar que los paradigmas que han dominado a las políticas culturales han sido resistidos, negociados, apropiados y/o utilizados estratégicamente.

Mariana Rúfolo, artista circense y creadora de Circo del Sur había comenzado con algunas propuestas experimentales de intervención socioeducativa desde el arte circense en el año 1991 en un barrio popular del conurbano bonaerense. Luego de notar el potencial de estas intervenciones para modificar desde diversos aspectos las vidas de niños y jóvenes de sectores vulnerabilizados, junto con otros referentes -artistas y trabajadores sociales- fue desarrollando propuestas que en un inicio (1995) se circunscribían al dictado de talleres en distintos barrios precarizados de la ciudad desde un convenio logrado con el Programa de Promoción Cultural del GCBA.

Luego de estos inicios, Circo del Sur fue creciendo, muchas veces presionado por la demanda de los propios jóvenes destinatarios que, habiendo comenzado la práctica artística circense de niños o adolescentes, ahora pretendían profesionalizarse. Dicha demanda implicaba una dedicación docente mucho mayor que la que unas horas de taller financiadas por el GCBA podría cubrir. Asimismo, la concepción pedagógica y de intervención social de la que partían implicaba pensar en un dispositivo integral, que no se circunscribiera solo a un taller de malabares o trapecio de dos horas por semana sino que involucrara la enseñanza de los diversos lenguajes circenses, la formación en producción, la creación artística, el acompañamiento socio-emocional de los jóvenes, la inserción barrial, el impulso de circuitos artístico-educativos en los barrios segregados, la alianza con diversas asocia- 
ciones de base territorial y el intercambio con otras experiencias de este tipo de propuestas que se iban multiplicando en distintos países del mundo ${ }^{5}$.

Esto los fue llevando a soñar y gestar una Escuela Municipal de Circo en el barrio Tres Rosas, al interior de la llamada villa 21-24 de Barracas. En 1999 se había conseguido construir un galpón desde Acción Social del GCBA al lado del comedor comunitario pero, en los años subsiguientes, se desataron una serie de conflictos que se sintetizan en la insuficiencia de recursos para mantener los sueldos de una escuela de circo como la que ya estaba funcionando. Por consiguiente, el galpón Escalando Altura quedó como un espacio en el barrio con talleres de circo y otras disciplinas artísticas, que continuaron manteniendo algunos de los integrantes de Circo del Sur como talleristas (docentes no formales) del GCBA. Sin embargo, ante estos conflictos, decidieron conformarse como Asociación Civil sin fines de lucro, a finales de 2002 para intentar promover el proyecto integral truncado. En sus palabras:

[Frente a una] real imposibilidad de trabajar (...) se plantea la necesidad de conseguir una autonomía con respecto al Estado. La creación de una Asociación Civil dará la posibilidad de independizarse del Estado y de poder gestionar de manera más organizada la colaboración y el apoyo de particulares, empresas, organismos, y hasta de las propias agencias estatales. (Documento realizado por Circo del Sur en 2010)

Desde su conformación como Organización de la Sociedad Civil en 2002 hasta la actualidad, han desarrollado un gran crecimiento. Actualmente trabajan con distintas líneas de acción que incluyen talleres comunitarios de distintas disciplinas artísticas a los que acceden más de 400 jóvenes al año, propuestas de formación profesionalizante y de formación de formadores en distintos lugares del país, un área de servicios culturales desde una productora cultural (que además cuenta con carpa de circo propia) y hasta un programa regional de fomento de habilidades socio-emocionales para mejorar la empleabilidad juvenil en convenio con destacadas escuelas de la región y el Cirque du Soleil. Estas distintas líneas de acción involucran la gestión asociada con diversas dependencias estatales locales y nacionales -en áreas de salud, educación, trabajo, cultura, entre otras- y con importantes agencias de financiación internacional.

\section{b. Aportes para el diseño de propuestas emergentes de intervención socio-artística con jóvenes vulnerados}

Un primer eje para analizar el modo en que desde Circo del Sur se han negociado y resignificado los paradigmas que fuimos recorriendo con anterioridad se vincula a la búsqueda de la organización por lograr cierta autonomía relativa frente al Estado. Dicha búsqueda es lo que se explica en la narrativa de la organización como la causa para formalizarse en una Asociación civil sin fines de lucro que permitiera independencia para delinear el propio proyecto, propósitos y objetivos a largo plazo y una estrategia de intervención socioartística integral. No obstante, tal como lo argumentaba la directora de la organización: 
No queremos que nos banque exclusivamente una fundación internacional. Yo creo que el Estado debe hacerse cargo de la cultura y la educación. (...) Tenemos, como actores socioculturales, la obligación de defender ese lugar en el Estado y si bien no queremos dejar de trabajar con el Estado, tampoco podemos estar a merced de los cambios políticos... porque nuestro centro son los pibes. (Mariana Rúfolo, Directora Circo del Sur. Entrevista 2008)

En contextos en los que el Estado se retiraba de su función como garante de derechos, diversos colectivos sociales, entre ellos grupos de artistas y trabajadores culturales, intentaron formalizar sus agrupaciones "por fuera" o "al costado" del Estado. Sin embargo, tal como observamos en otras experiencias del campo arte-transformador en un trabajo comparativo (Infantino, et. Al., 2016):

No hay en sus discursos un aval ante ese corrimiento sino, justamente, una estrategia para intentar alternativas para gestionar y/o presionar políticas (...). En la creación de vínculos y articulaciones que implican negociaciones, disputas y tensiones entre agentes diversos y desigualmente posicionados (Infantino, 2014) (...), las organizaciones irán definiendo un posicionamiento respecto a lo que se "elige" aceptar o no, respecto a dónde, cómo, con qué condiciones y de qué modo llevar adelante las alianzas imprescindibles para sostener el trabajo y para pensarlo a largo plazo. (...) Así, las organizaciones analizadas, desarrollan un entramado de relaciones -asimétricas, cambiantes, ambiguasque se tejen entre diferentes organismos del Estado y actores de la sociedad civil para la formulación, implementación (y financiamiento) de sus acciones. (Infantino, et. al., 2016, p. 10)

Cabe destacar que las posibilidades de relativa autonomía lograda por Circo del Sur a lo largo de los casi 15 años desde que se formalizó como Organización de la Sociedad Civil no pueden ser vistas como procesos ideales y no conflictivos. Una de las mayores dificultades a las que se enfrentan este tipo de organizaciones se vinculan centralmente con la inestabilidad financiera al depender para su continuidad de "conseguir proyectos". Una de las estrategias que fueron utilizando desde esta organización como desde tantas otras del campo arte-transformador, fue multiplicar las fuentes de financiación y aliarse con actores diversos para evitar que frente, por ejemplo, a cambios de gestión gubernamental o a lineamientos de políticas, la organización se quede sin financiación. No obstante, más allá de este tipo de estrategias exitosas que, en casos ideales, permiten mantener la relativa autonomía en el diseño de las líneas de acción, en ocasiones las organizaciones deben amoldar sus discursos en función de "modas" o cambios en los paradigmas en los que se conceptualiza la cultura, los jóvenes, la pobreza y sus posibles soluciones. Tal como sugería Belfiore para el caso inglés, estos usos pueden ser vistos como una estrategia de supervivencia para los artistas en función de garantizar la financiación y la posibilidad de desarrollo de sus propuestas de trabajo (Belfiore, 2002).

En efecto, el corrimiento hacia la ponderación del impacto social del arte por sobre otras consideraciones ha llevado a muchas de estas organizaciones -y también a diversas pro- 
puestas estatales de políticas culturales que conforman el campo arte-transformador-a caer en una discursiva vinculada a paradigmas preventivos y asistenciales (Kantor, 2008; Roitter, 2009) en la justificación de sus propósitos. En otros trabajos (Infantino, 2016b) propuse que muchos de los discursos que sustentaron desde sus inicios a diversos proyectos de Circo Social en América Latina incluyeron una visión que abogaba por pensar al arte como un derecho y a los jóvenes destinatarios como sujetos creativos, ciudadanos plenos con capacidades y saberes en el marco del paradigma de la educación popular. No obstante, para gestionar financiación, resultaba muchas veces más efectivo hablar de, por ejemplo, "beneficiarios en riesgo" o de "contención" y "autoestima" en lugar de "lucha" y "emancipación". En este sentido, estudié la apropiación de conceptos desde una concepción de usos estratégicos de los mismos. Los sentidos circulan, están disponibles, se apropian, reproducen y/o se negocian y disputan. Sin embargo, no siempre existen márgenes amplios para estos usos estratégicos y los mismos dependerán de disputas de poder en coyunturas políticas concretas.

Justamente, el caso de Circo del Sur y su relativo "éxito" se relaciona, entre otras cosas, con haber podido mantener una estructura consolidada de trabajo: dos de los cuatro responsables formales de la organización son sus creadores iniciales, los artistas Mariana Rúfolo y Pablo Holgado que comenzaron a principios de los años 1990 y las otras dos integrantes, Natalia Lázzaro y Vanesa Zambrano participan en la misma desde comienzos de los 2000. Asimismo, plantean en sus narrativas haber tenido "suerte" con algunas fuentes de financiación de larga duración que les permitieron tener dinero para pagar sueldos a personas que se dedican a diseñar proyectos, pensar estrategias a largo plazo que involucren el ingreso financiero más allá de "los proyectos" puntuales, por ejemplo, diseñando un área de servicios culturales -sus espectáculos-. Por otra parte, a lo largo de estos años de trabajo han logrado incorporar y formar un gran equipo de educadores, algunos de los cuales han sido estudiantes del proyecto. Otro de los ejes a resaltar se relaciona con el armado de redes que los han vinculado a experiencias internacionales de similares características que favorecieron su crecimiento ${ }^{6}$. Y agregaría, se relaciona también con una gran capacidad de trabajo y una importante cuota de creatividad para mantener, no sin dificultades, un programa integral de trabajo socio-artístico comunitario que fue logrando espacios para disputar y negociar formas específicas de pensar a los destinatarios de sus acciones -los jóvenes pobres de barrios precarizados-, y maneras de educarlos en función de habilitarles espacios creativos y medios para expandir sus experiencias de vida.

Podemos resumir el foco de sus propuestas en torno a algunas preguntas concretas: ¿Qué arte? ¿Para qué? ¿Para quién? ¿Cómo?

¿Qué arte? Circo del Sur trabaja con las artes circenses. Artes que históricamente en nuestra ciudad fueron deslegitimadas como artes menores, populares (en sentido peyorativo). Son artes que atravesaron un proceso de resurgimiento en los años 1980 post-dictatoriales vinculado, centralmente, a la ocupación de los espacios públicos urbanos en manos de jóvenes artistas desde un discurso que abogaba por la democratización de las artes (Infantino, 2014). Esos artistas que, como Mariana (la creadora de Circo del Sur) se acercaban a los lenguajes circenses $-\mathrm{y}$ a otras artes populares que se entremezclaban en el contexto de época- desde la experimentación y desde la necesidad de encontrarse con prácticas artísticas que permitan trascender el individualismo, el miedo, la apatía. Llevar el arte a 
la plaza pública en los '80 y luego en los neoliberales '90 implicó, para muchos jóvenes, la posibilidad de participación y compromiso social y una vía para disputar los ideales de la época, resistiendo desde modalidades de trabajo colectivo, autogestivo, no elitista. En este sentido, la concepción de arte que manejan desde Circo del Sur se aparta de la concepción canónica del mismo, se piensa como herramienta educativa emancipadora inspirada en los aportes de la pedagogía crítica -recuperando la obra de Paulo Freire- y en propuestas que disputan el elitismo y autonomía del campo artístico, cuestionando el "arte por el arte" y ponderando su función social, valorizando la co-autoría o autoría colectiva de las obras y, centralmente, poniendo el foco en el potencial creativo de todos los sectores de la sociedad (Palacios Garrido, 2009).

¿Para qué? Circo del Sur se propone transformar inequidades - de acceso y participación en la cultura y/o de oportunidades de formación artística-, promover cambios -ya sea personales o grupales-, luchar por un desarrollo cultural más equitativo, disputar por circuitos culturales en espacios urbanos desiguales y segregados, cuestionar visiones estigmatizantes acerca de las poblaciones subalternas (Infantino, 2016a). En sus palabras:

Pretendemos confrontar con la problemática de la exclusión de ciertos sectores que frecuentemente se encuentran en un circuito de vida cultural relegada. Apostamos aún más: no sólo pretendemos garantizar el acceso a bienes y servicios culturales sino también el derecho a producir arte en sectores que de otro modo no accederían al mismo, en igualdad de condiciones. Nuestra propuesta se define alrededor de necesidades esenciales (más bien no tangibles), donde la educación, la participación, la integración a la vida comunitaria y el apoyo a los grupos familiares, son elementos centrales. (Carpeta Institucional Circo del Sur, 2013).

¿Para quién? Circo del Sur dirige su trabajo centralmente a los que conceptualiza como protagonistas de una experiencia de formación y experimentación artística: los y las jóvenes que habitan en barrios segregados - villas- de la ciudad de Buenos Aires. Aquí se posicionan en un paradigma de derechos disputando otros paradigmas preventivos, asistenciales o tutelares que históricamente caracterizaron las intervenciones con poblaciones "menores" vulneradas y que, aun luego de más de 10 años de sancionada la Ley de Protección Integral de los Derechos de las Niñas, Niños y Adolescentes (Ley 26.061/05) continúan presentándose como discursiva que justifica los trabajos con jóvenes de sectores vulnerables (Kantor, 2008; Roitter, 2009). Por consiguiente, buscan promover el derecho a la expresión de sujetos que habitualmente viven en circuitos culturales relegados sin acceso igualitario a posibilidades de disfrute, goce y producción artística y de esta manera intentan, entre otras cosas, revertir las representaciones estigmatizantes que se han asentado sobre estos sujetos juveniles destacando sus capacidades creativas en contraposición a las representaciones que los niegan y estigmatizan (Chaves, 2006).

¿Cómo? Como ya mencionamos, inspirados en la pedagogía crítica parten de una concepción de los jóvenes como protagonistas de su experiencia de formación. Así, trabajan CON los jóvenes y no PARA ni POR ellos, intentando romper con el paradigma asistencial de atención a jóvenes en situación de vulnerabilidad. Sus metodologías de enseñanza artística 
se amoldan a los tiempos y deseos de los jóvenes. A partir de fomentar la experimentación con el cuerpo propio y la confianza en el cuerpo del otro buscan revertir miedos, desconfianzas. "Volar en un trapecio, lanzarse al vacío implica experimentar y arriesgar. Un joven que se atreve a volar puede imaginar y soñar un futuro en el que se convierta en protagonista de sus elecciones de vida" (Entrevista Mariana Rúfolo, 2008). No obstante, para "atreverse a volar" es necesaria no solo confianza en sí mismo, sino también en el otro. Así, el riesgo en un marco de control resulta sumamente atractivo para muchos jóvenes. Las artes circenses exigen complementariedad de fuerzas y talentos, trabajo en equipo y atención al otro con el que se trabaja. Por consiguiente, en la práctica del circo la cooperación, lo colectivo y la solidaridad sin las cuales no se podría concebir un espectáculo, antes de ser valores morales a "inculcarle" al otro son condiciones de funcionamiento. Mariana Rúfolo suele plantearlo a partir de un ejemplo de la práctica:

Cuando haces una pirámide humana, confías en el que te sostiene, cuidas tu propio cuerpo y el cuerpo del otro. De otra manera, es imposible hacer que una pirámide grupal funcione. $\mathrm{O}$ cuando estas invertido del trapecio [colgado cabeza abajo] es una instancia para mirar el mundo desde otra perspectiva y ampliar el punto de vista. (Entrevista Mariana Rúfolo 5/4/2008)

Sin embargo, tal como venimos sosteniendo, este programa integral de trabajo socioartístico comunitario no ha quedado exento de las dificultades que implican tener que justificar la práctica más que como un derecho como un paliativo para asistir y/o prevenir/ controlar a los jóvenes pobres. En palabras de Pablo Holgado:

Aún tenemos la marca de que el circo sea considerado como "arte menor" en Latinoamérica. Tenemos que generar más audiencias interesadas en el circo y en propuestas innovadoras, que las hay, aún con falta de recursos y de promoción. Y también tenemos que pelear por separarnos de ser vistos como propuestas asistencialistas. Si bien nuestra puerta de entrada es lo social a diferencia de Francia, por ejemplo, más centrado en lo creativo, nuestros objetivos son similares: formamos a nuestros jóvenes como artistas, como sujetos creativos y capaces de producir hechos artísticos. (Pablo Holgado, Charla Circo en el $5^{\circ}$ Festival Internacional de Circo Buenos Aires Polo Circo, mayo 2013)

En esta línea cabe destacar que Circo del Sur hasta el año 2015 se denominaba formalmente Circo Social del Sur. Decidieron cambiar su denominación por diversos motivos que exceden este trabajo pero que podemos sintetizar en esta necesidad de despegarse del discurso anclado en "lo social" (la asistencia y la prevención hacia los pibes vulnerables). En esta línea, considero que existe un movimiento en el campo arte- transformador en torno a resignificar y expandir creativamente la noción de arte y transformación social. ¿Trasformar es llevar arte a otros? ¿Transformar es luchar por brindar espacios creativos y ofertas de acceso al derecho que todos tenemos de ser protagonistas de hechos artísticos? ¿Transformar es disputar cánones valorativos de arte instalando a las artes circenses y a otras artes populares como ofertas culturales legítimas? ¿Transformar es abrir espacios, 
nuevos circuitos culturales, nuevos procesos de enseñanza? ¿Transformar es luchar por el reconocimiento de estas artes y por políticas que las promuevan?

\section{Consideraciones finales}

En este trabajo partí de pensar el terreno de las políticas culturales como una arena de negociaciones y disputa en la que intervienen múltiples agentes que trascienden la exclusividad estatal y que, entre otras cuestiones, debaten los sentidos atribuidos a ciertos conceptos clave vinculados al de Cultura como Desarrollo, Inclusión, Transformación social, Derechos (culturales). En este sentido intenté atender al modo en que se disputan estos sentidos diferenciales entre los diversos actores involucrados en su diseño, implementación y uso.

Para ello, propuse recorrer la trayectoria de una organización social cuya experiencia se enmarca en el campo arte-transformador, un área de políticas culturales que promueven usos del arte para la trasformación social con jóvenes de sectores vulnerabilizados. Analicé así la trayectoria de Circo del Sur y los modos en los que vienen aportando al diseño y gestión de propuestas emergentes en la política cultural de la ciudad de Buenos Aires. Fundamentalmente, argumenté cómo sus propuestas intentan trascender una visión economicista y mercantilizada de la cultura como recurso para el desarrollo y un uso instrumental del arte para morigerar la desigualdad e intervenir en la vida de los jóvenes, buscando en cambio promover estrategias redistributivas que disputen inequidades y garanticen igualdad en el acceso, participación y producción cultural urbana.

$\mathrm{Al}$ analizar la trayectoria de Circo del Sur y algunas de las propuestas que a lo largo de sus más de 20 años de historia fueron desarrollando creativamente, se puede apreciar el modo en que, tal como históricamente hicieron los artistas circenses, esta organización se caracterizó por traspasar límites, desafiar convenciones y expandir posibilidades en el trabajo de intervención social desde el arte. Sin embargo, analicé las complejidades que atravesaron a la largo de su trayectoria donde no siempre existieron márgenes amplios para desafiar los discursos hegemónicos en torno a las juventudes pobres y a los usos del arte y la cultura como herramientas de transformación social.

\section{Notas}

1. En el marco de los avances en una investigación colectiva en curso al interior del Proyecto de Reconocimiento Institucional PRIG (2016-2018) de la Facultad de Filosofía y Letras de la Universidad de Buenos Aires denominado "Políticas Arte Transformadoras. Usos del Arte para la transformación social en la ciudad de Buenos Aires” bajo mi dirección, hemos propuesto la categoría de campo arte-transformador para enmarcar estas prácticas de intervención socio-artística. Argumentamos que el mismo está compuesto por distintos agentes institucionales -tanto públicos como privados/sociales- que impulsan iniciativas múltiples de promoción de disciplinas artísticas de los más diversos lenguajes destinadas mayoritariamente al trabajo con jóvenes que habitan contextos precarizados. 
Hablamos de campo arte-transformador, intentando una definición que retoma la noción bourdieuana de campo en tanto nos permite circunscribir un espacio social de producción y circulación de un capital que ordena y posiciona luchas y estrategias en torno a su apropiación y circulación, y habilita centrarse en los conflictos que surgen en ese espacio específico. En este sentido, pensar un campo nos lleva a atender al modo en que la noción de arte y transformación social opera en dicho espacio como categoría nativa, en tanto es una noción utilizada, impulsada y disputada al interior de grupos y colectivos artísticos que trabajan desde estas propuestas (Infantino et. al 2016; Berzel, et. al. 2016).

2. Conocí a sus impulsores en 1998 pero me acerqué desde el trabajo de campo en 2008. Allí realicé un trabajo inicial que involucró entrevistas en profundidad a sus directores y a sus jóvenes destinatarios. Luego mantuve una relación de trabajo colaborativo en el que acompañé y asesoré a la organización en diversas instancias, desde la escritura de proyectos a la colaboración en el armado de instrumentos de reflexión y evaluación de sus acciones o el dictado de charlas y clases a los jóvenes participantes. Aquí recupero reflexiones de estos años de trabajo conjunto que involucraron entrevistas, observación participante, acompañamiento de trayectorias, participación y coordinación de instancias de debate -foros, charlas-, entre otras.

3. Si bien la temática de la creatividad y lo creativo exceden el recorte de este trabajo, resulta necesario realizar algunas aclaraciones. La promoción de las "economías creativas" a través de la atracción de las "clases creativas" (Florida, 2002) para conformar ambientes creativos, redes y conglomerados (clusters) de innovación dando lugar a la generación de “ciudades creativas" (Yúdice, 2008, Pratt, 2010, Bayardo 2013), se erige como una retórica destacada que se entrecruza con la temática de las políticas culturales urbanas en diversas ciudades del mundo, y, sobre todo en los últimos 10 años en la ciudad Autónoma de Buenos Aires (Bayardo, 2013). Existe una abundante literatura crítica al respecto que, fundamentalmente destaca en las propuestas de desarrollo a partir de "la creatividad" la aceptación acrítica de determinados puntos de vista procedentes del neoliberalismo económico. Las mismas suelen responder a intereses particulares y ocultar fenómenos de segregación urbana que frecuentemente se desatan como consecuencia de estas propuestas (Harvey, 1989; Yúdice, 2008; Pratt, 2010; Bayardo, 2013). Para un abordaje detallado de la temática en Buenos Aires puede consultarse, entre otros: Bayardo 2013.

4. Bajo este término se engloban una serie de fórmulas o "recetas" emanadas de los principales organismos financieros internacionales para los países "en desarrollo" azotados por la crisis. Las mismas abarcaban políticas que propugnaban la estabilización macroeconómica, la liberalización económica, la expansión de las fuerzas del mercado dentro de la economía doméstica y la reducción del Estado.

5. Durante los años 1990 surgen en distintos lugares del mundo propuestas que más tarde serán conceptualizadas bajo el concepto de Circo Social, que en líneas generales, remite al uso de la enseñanza de técnicas circenses para trabajar con poblaciones vulneradas. En sus más de dos décadas de desarrollo, el llamado Circo Social se fue convirtiendo en una estrategia para trabajar con niños/as y jóvenes en situaciones vulnerables así como para enfrentar distintas problemáticas sociales, desde conflictos bélicos al trabajo con personas en situaciones de encierro o con mujeres abusadas, o con salud mental y discapacidad, entre otras. Para profundizar en su desarrollo ver: Infantino, $2016 \mathrm{~b}$. 
6. Cabe destacar en esta dirección a la Federación Iberoamericana de Circo (FIC) conformada por destacadas organizaciones que comenzaron sus acciones desde el Circo Social en los años '90. Sus integrantes son: Circo del Sur (Argentina), Carampa (España), Circolombia (Colombia), Crecer e Viver (Brasil), La Tarumba (Perú), Circo del Mundo (Chile), Chapito (Portugal).

\section{Referencias Bibliográficas}

Balazote, A. (2007). Antropología Económica y Economía Política. Córdoba: Centro de Estudios Avanzados.

Bayardo R. (2013). Políticas culturales y economía simbólica de las ciudades: 'Buenos Aires, en todo estas vos'. Latin American Research Review 48, 100-142.

Bayardo, R. y Lacarrieu M. (1999). Nuevas perspectivas sobre la cultura en la dinámica global / local". En: La dinámica global / local: Cultura y comunicación: nuevos desafíos, compilado por Rubens Bayardo y Mónica Lacarrieu, 9-24. Buenos Aires: Ediciones CICCUS-La Crujía.

Belfiore, E. (2002). Art as a means of alleviating social exclusion: Does it really work? A critique of instrumental cultural policies and social impact studies in the UK". International Journal of Cultural Policy 8 (1): 91-106.

Berzel, M., Echeverría, A., Infantino, J. y Talellis, V. (2016). “El campo arte-transformador. Propuestas de intervención socio-artísticas con jóvenes”. V Reunión Nacional de Investigadores/as en Juventudes Argentinas. Rosario, 21, 22 y 23 de Noviembre de 2016. Facultad de Ciencia Política y Relaciones Internacionales. Facultad de Derecho. Universidad Nacional de Rosario. Rosario, Santa Fe, Argentina.

Chaves, M. (2006). "Juventud negada y negativizada: representaciones y formaciones discursivas vigentes en la Argentina contemporánea”. Revista Última Década No 23. Viña del Mar: CIDPA. Disponible en http://www.cidpa.cl.

Crespo, C., Morel, H. y Ondelj, M. (comp.) (2015). "Introducción". En: La política cultural en debate. Diversidad, performance y patrimonio cultural, Ediciones Ciccus, Buenos Aires, Argentina, 2014.

Florida, R. (2002). The Rise of the Creative Class. New York: Basic Books.

Harvey, D. (1989). From managerialism to entrepreneurialism: The transformation in urban governance in late capitalism. Geografiska Annaler 71B(1): 3-17.

Infantino, J. (2012). Cultura, Jóvenes y Políticas en disputa. Prácticas circenses en la ciudad de Buenos Aires. Tesis Doctoral. Facultad de Filosofía y Letras. Universidad de Buenos Aires. Mimeo.

. (2014). Circo en Buenos Aires. Cultura, Jóvenes y Políticas en disputa. Buenos Aires, Instituto Nacional del Teatro.

. (2016a). "De pluralizar las políticas culturales al arte para la transformación social”. En: Cardini, L. y Madrigal González, D. (coords.) Las Políticas culturales en la América diversa. El Colegio de San Luis de Potosí, S. C. México. (En prensa)

. (2016b). "Experiencias de intervención social desde el arte (circense) como esfera de desarrollo de políticas culturales en Argentina”. En: Rotman, M. (Editora res- 
ponsable) Dinámicas de poder, estado y sociedad civil en los procesos patrimoniales y las políticas y gestión de la cultura. Editorial de la Facultad de Filosofía y Letras- Universidad de Buenos Aires. Colección SABERES. (En prensa).

Infantino, J., Moyano, M., Berzel, M. y Echeverría, A. (2016). "Notas para un análisis de experiencias arte-transformadoras dirigidas a jóvenes en la ciudad de Buenos Aires". VIII Jornadas de Antropología Social Santiago Wallace. Sección de Antropología Social del Instituto de Ciencias Antropológicas, Facultad de Filosofía y Letras-Universidad de Buenos Aires. 27, 28 y 29 de julio de 2016, Ciudad Autónoma de Buenos Aires, Argentina.

Kantor, D. (2008). Variaciones para educar adolescentes y jóvenes (1a ed.). Buenos Aires: Del Estante.

Kliksberg, B. (1999). "El rol del capital social y de la cultura en el proceso de desarrollo". En Kliksberg, B. y Tomasini, L. (comps), Capital social y cultura: Claves estratégicas para el desarrollo, pp. 9-55. Maryland, BID, Fundación Felipe Herrera.

Murillo, S. (2006). "Del par normal-patológico a la gestión del riesgo social. Viejos y nuevos significantes del sujeto y la cuestión social". En: Murillo, S. (coord.), Banco Mundial. Estado, Mercado y Sujetos en las nuevas estrategias frente a la cuestión social, Cuadernos de Trabajo 70, pp. 11-38. Buenos Aires, Centro Cultural de la Cooperación Floreal Gorini.

Palacios Garrido, A. (2009). El arte comunitario: origen y evolución de las prácticas artísticas colaborativas. Arteterapia - Papeles de arteterapia y educación artística para la inclusión social 197. Vol. 4/: 197-211.

Pratt, A. C. (2011). "The cultural contradictions of the creative city". City, culture and society, no. 2, Elsevier, Amsterdam, pp. 123-130.

Rabossi, F. (2000). "Límites difusos: animación cultural, trabajo y voluntarismo". Cuadernos de Antropología Social No 11. Buenos Aires, Pp. 243-267.

Roitter, M. (2009). "Prácticas intelectuales académicas y extra-académicas sobre arte transformador: algunas certezas y ciertos dilemas". En: Nuevos Documentos CEDES, $N^{\circ} 66$. http://www.cedes.org.ar/Publicaciones/Ndoc_c/66.pdf

Yúdice, G. (2002). El recurso de la cultura. Usos de la cultura en la era global. Barcelona, Gedisa. Yúdice, G. (2008). Modelos de desarrollo cultural urbano: ¿gentrificacion o urbanismo social? Alteridades 18(36): 47-61.

\begin{abstract}
As part of a diversification of cultural policies, since the 1990s, albeit with greater intensity in 2000 in the Latin American context, a "new" area of (cultural) policies emerges proposing arts as a strategy for social transformation. In a significant number, this area was developed from proposals of artistic groups and community experiences that questioned and resignified hegemonic discourses about the social role of arts and their potential to creatively develop inclusive cultural policies. These proposals intended to struggle against urban segregation, stigmatization of vulnerable groups and unequal opportunities for access and participation in culture and arts, as part of a paradigm of participatory democracy, calling for the expansion of (cultural) rights.

In this paper I propose to analyse the role of (circus) artists -conformed now in organizations of the civil society and turned into activists, designers/managers/cultural
\end{abstract}


workers-, in the critical proposal of alternatives against paradigms that have characterized the cultural policies. These paradigms have installed, among other things, culture as a "resource" to combat the undesirable effects of neoliberalism by promoting the social risk management often attributed to urban poor young people. The intention is to analyse options that face this rhetoric of control of the populations affected by neoliberal development through art and culture and who proclaim the design of redistributive strategies, anchored in a paradigm of rights, that dispute inequalities and guarantee equality in access, participation and urban cultural production.

Key words: cultural policies - art and transformation field - social participation - policy design - circus art.

Resumo: Como parte de uma diversificação e pluralização do campo das políticas culturais, desde a década de 1990 ainda mais fortemente em 2000 no contexto da América Latina, uma área de propostas, ações e políticas culturais que postulam a arte como estratégia para transformação social começa a se desenvolver. Esta área se originou em grande parte das propostas de grupos artísticos e experiências comunitárias que foram resinificando o "papel social" da arte e seu potencial para o desenvolvimento de políticas culturais inclusivas. Estas propostas visam combater a segregação urbana, a estigmatização de grupos vulneráveis e a desigualdade de oportunidades de acesso e participação na cultura e nas artes como parte de um paradigma de democracia participativa que defende a expansão dos direitos (culturais).

Neste artigo proponho analisar o papel dos artistas (circo) -constituídos agora em organizações da sociedade civil e ativistas que se tornaram designers/gestores/trabalhadores culturais- na proposição crítica de alternativas aos paradigmas que caracterizaram as políticas culturais. Esses paradigmas têm promovido, entre outras coisas, à cultura como um "recurso" para combater os efeitos indesejados do neoliberalismo postulando a gestão do risco social, muitas vezes atribuído à juventude urbana pobre. A intenção é analisar opções que enfrentam essa retórica do controle das populações afetadas pelo desenvolvimento neoliberal através da arte e da cultura, promovendo o desenho de estratégias de redistribuição, ancorados em um paradigma de direitos, que desafiam as desigualdades e visam assegurar a igualdade de acesso, participação e produção cultural urbana.

Palavras chave: políticas culturais - campo da arte e transformação - participação social formulação de políticas - arte circense. 

Fecha de recepción: marzo 2017

Fecha de aceptación: octubre 2017

Versión final: marzo 2019

\section{Investigación y gestión cultural: diseñando articulaciones $^{1}$}

Verónica Griselda Talellis ${ }^{\star 1}$, Elsa Alicia

Martínez ${ }^{\star 2}$, Karen Avenburg ${ }^{\star 3}$ y Alina Cibea ${ }^{\star 4}$

Resumen: Un gran número de proyectos y programas de orquestas infantiles y juveniles representan iniciativas que desarrollan la enseñanza musical a través de la formación orquestal, enfocándose en poblaciones en situación de vulnerabilidad. En el presente trabajo presentamos algunas reflexiones en base a una investigación realizada en los años 2014 y 2015 sobre los proyectos y programas de orquestas que se desenvuelven en el Gran Buenos Aires (Argentina). Pretendemos especialmente discutir algunos aspectos que en el hacer etnográfico se nos presentaron como nuevos canales de diálogo y reflexión para pensar en los cruces e intersecciones entre la gestión cultural y la investigación sociocultural. Deseamos entonces dar cuenta de una experiencia de investigación que busca diseñarse (y rediseñarse) a partir de una articulación dinámica con la misma gestión; consideramos a la vez que las investigaciones pueden constituirse en herramientas válidas para el diseño y la evaluación en el campo de la gestión cultural.

Palabras clave: orquestas infantiles y juveniles - gestión cultural - investigación sociocultural.

[Resúmenes en inglés y portugués en las páginas 104-105]

${ }^{\left({ }^{*}\right)}$ Profesora y Licenciada en Ciencias Antropológica (UBA). Es investigadora de temáticas relacionadas con la música como expresión artística para la transformación social y forma parte del proyecto de reconocimiento institucional avalado por la FFyL-UBA "Políticas Arte transformadoras. Usos del arte para la transformación social en la ciudad de Buenos Aires”. Integra el grupo Música e Inclusión con el cual desarrolla el Proyecto de investigación, dirigido por la Dra. Karen Avenburg, sobre las orquestas y coros infantiles y juveniles del Gran Buenos Aires radicado en la Universidad Nacional de Avellaneda (PROAPI 2014, UNDAVCYT 2016-2018).

${ }^{\left({ }^{*}\right)}$ Periodista profesional y estudiante avanzada de la Licenciatura en Gestión cultural. Desde su rol de periodista estuvo vinculada con la cultura. Se desempeñó en medios gráficos, radiales y televisivos de alcance local y nacional en las áreas de redacción y producción. Integra el equipo de investigación "Música e Inclusión social: Los proyectos de Orquestas Infantiles y juveniles en el Gran Buenos Aires”. Además integró los equipos de investigación "Las prácticas de la diversidad Cultural en Avellaneda", "Experiencias contra-hegemónicas y memorias de resistencias: Teatro Abierto y sus legados", y actualmente en la investigación "La política como tragedia, la verdad como farsa. Cultura, política, co- 
municación y neohigienismo en la Argentina actual". Es miembro del comité organizador del 1er. Congreso de Gestión Cultural UNDAV.

${ }^{\left({ }^{*}\right)}$ Doctora en Ciencias Antropológicas (UBA). Licenciada y Profesora en Ciencias Antropológicas (UBA). Docente e investigadora de la Universidad Nacional de Avellaneda (Departamento de Humanidades y Artes). Desde un enfoque etnográfico ha estudiado las prácticas musicales y las performances en general, en su relación con la construcción de identidades, la ritualidad, la teatralidad, las políticas culturales y la inclusión social. Entre los años 2002 y 2012 realizó sus investigaciones en la localidad de Iruya (Salta); actualmente estudia los Proyectos de Orquestas Infantiles y Juveniles en el Gran Buenos Aires. Forma parte del Cuerpo Académico del Doctorado en Diseño y dirige la Línea de Investigación Cruces entre Cultura y Diseño.

${ }^{\left({ }^{*}\right)}$ Investigadora en Ciencias Sociales, centra su trabajo en temas relacionados a la integración, inclusión social y la anti-discriminación, tanto en contextos europeos como latinoamericanos. Tiene un Master en Estudios Internacionales de la Universidad de Viena y la Licenciatura en Ciencias Políticas de la Universidad de Bucarest. A presente es Doctoranda en Ciencias Sociales en FLACSO-Argentina e integra el Grupo de Investigación Música e Inclusión que funciona en el marco del Observatorio de Ciudadanía Cultural de la Universidad Nacional de Avellaneda. Anteriormente trabajó como investigadora en políticas públicas y movimientos migratorios en el International Centre for Migration Policy Development en Viena.

\section{Introducción}

Existen numerosos proyectos, a lo largo del mundo, de Orquestas Infantiles y Juveniles. Uno de los casos más difundidos es el de Venezuela, pero existen muchas más experiencias, como las de Chile, Paraguay, Brasil, Escocia y Sudáfrica, entre otras. Argentina también tiene las suyas. Aunque presentan muchas variantes, estas propuestas generalmente coinciden en poner el acento tanto en la formación musical a través de la práctica orquestal, como en las poblaciones en situación de vulnerabilidad. Se trata de aquello que en la agenda pública se ha denominado inclusión, integración o transformación social.

Se advierte que proyectos con estas características se han ido multiplicando desde las últimas décadas del S XX. Esta proliferación no parece ser ajena a las coyunturas sociales y económicas propias de configuraciones políticas neoliberales ${ }^{2}$ que se desarrollaron tanto en Europa (Belfiore, 2002; Barbieri, Partal y Merino, 2011) como en el ámbito latinoamericano (Kliksberg, 2014; Pérez Rubio, 2006; Villarreal, 1996); dichas configuraciones han traído aparejado un aumento de la exclusión social.

Si bien esta coyuntura ha jugado un papel importante en el desarrollo de políticas culturales $^{3}$ (Barbieri, Partal y Merino, 2011; Belfiore, 2002), es necesario aclarar que la expansión de proyectos como los de las orquestas infantiles y juveniles excede ese contexto específico, dando cuenta de emprendimientos que responden $-\mathrm{o}$ buscan responder- a necesidades 
socioculturales diversas. En efecto, la música, entendida como una manifestación cultural que no sólo consiste en estructuras de sonido sino también en los modos en que la gente hace, percibe y se refiere a la música, implica y a la vez forja relaciones sociales. Es por ello que consideramos que las orquestas infantiles y/o juveniles pueden erigirse como espacios de interrelación, de integración y de construcción compartida, y como campos propicios para la pluralidad (Muiños, 2010).

En el presente trabajo presentaremos algunas reflexiones que son producto de una investigación realizada en los años 2014 y 2015 sobre las orquestas juveniles e infantiles del Gran Buenos Aires ${ }^{4}$. Nos proponemos esbozar algunos aspectos que en el hacer etnográfico se nos presentaron como nuevos canales de diálogo y reflexión para pensar en los cruces e intersecciones entre la gestión y la investigación sociocultural. Entendemos que estas intersecciones nos permiten pensar en clave del diseño tanto de los proyectos de gestión en el campo cultural, como de los proyectos de investigación con miras a articularse dinámicamente con la gestión. Por un lado, queremos resaltar la importancia de la investigación sociocultural para el diseño de políticas, programas, proyectos en el campo cultural; y por el otro lado, señalamos la centralidad del diálogo con el campo de la gestión cultural a la hora de diseñar una investigación. Discutimos estas cuestiones en el caso de las políticas culturales específicas que atañen a los proyectos y programas de orquestas infantiles y juveniles que estudiamos.

\section{Marco conceptual: exclusión/inclusión social. Música y políticas culturales}

El concepto de exclusión social fue desarrollado por la sociología francesa en los años '60 y, expandiéndose de forma progresiva a otras regiones, adquirió centralidad como problemática social (Belfiore, 2002; Castel, 1997; Fitoussi y Rosanvallon, 1997; Pérez Rubio, 2006; Villarreal, 1996). El mismo da cuenta del intento de reconceptualizar las desventajas sociales generadas en el marco de los cambios socioeconómicos propios de la postmodernidad y permite "ver la pobreza y la desventaja como multi-dimensional antes que meramente en términos de ingreso y egreso. Aun cuando la desventaja material sigue siendo el foco principal de estrategias de inclusión social, ellas también comprenden nuevos e importantes aspectos" (Belfiore, 2002, p. 3).

Ahora bien, hablar de inclusión social como problemática que comprende pero excede la diferencia material, posibilita pensar en políticas públicas tendientes a la inclusión social que no se enfoquen únicamente en la dimensión económica. Pues sin descontar la innegable relevancia de esta última, no podemos desconocer las dimensiones culturales, por ejemplo, que son parte constitutiva de este fenómeno. Se advierte entonces la centralidad de las políticas culturales en tanto intervenciones orientadoras del desarrollo simbólico de una sociedad (Bayardo, 2000). Retomamos la definición de Néstor García Canclini (1987, p. 26), según la cual las políticas culturales se entienden como:

El conjunto de intervenciones realizadas por el Estado, las instituciones civiles y los grupos comunitarios organizados a fin de orientar el desarrollo simbólico, satisfacer las necesidades culturales de la población y obtener consenso para un tipo de orden o de transformación social". 
Se puede sostener desde esta definición que, como enfatiza Héctor Olmos (2008), todo régimen político desarrolla su propia política cultural, aun cuando no la enuncie en forma explícita.

Se ha observado que desde fines del siglo pasado diversos organismos de gobierno y grupos comunitarios han puesto el énfasis en las contribuciones que pueden realizar las artes en la búsqueda de la inclusión social (Belfiore, 2002 y 2006). En ocasiones, se espera que los gestores culturales atiendan prioridades de otras áreas y validen su trabajo demostrando contribuir a la resolución de problemáticas de las agendas políticas más amplias -prevención del delito, fracaso escolar, entre otros- (Barbieri, Partal y Merino, 2011; Belfiore, 2006). Esto no es ajeno al hecho de que, como observa Raggio (2013), el reconocimiento de los derechos culturales es un campo aún en disputa respecto al contenido de dichos derechos y a la misma posibilidad de que ese reconocimiento se realice efectivamente.

A partir de lo antedicho indagamos en los proyectos y programas de orquestas infantiles y juveniles en tanto implementaciones de políticas culturales que efectivamente buscan intervenir en la producción de sentido de las sociedades en las que se insertan.

\section{Abordaje y construcción del campo}

Esta investigación se desarrolló durante los años 2014 y $2015^{5}$ en el Gran Buenos Aires, abarcando así a la Ciudad Autónoma de Buenos Aires y los 24 partidos ${ }^{6}$ del Gran Buenos Aires. La misma consistió en la realización de un rastreo que incluyó las siguientes variables: nombre, locación, fecha de creación, articulación institucional, objetivos, población destinataria y repertorio. Buscamos realizar un estudio descriptivo que pudiera contribuir a la visibilidad, valorización y análisis de estas iniciativas.

El rastreo de los diferentes proyectos o programas de orquestas infantiles y juveniles que se despliegan en esta área requirió de una estrategia metodológica que combina: por un lado, entrevistas semi-estructuradas a integrantes responsables de los proyectos de gestión pública. Por otro lado, rastreo a través de diversos medios de comunicación tales como periódicos, revistas, sitios web de diferentes organismos de gobierno (nacional, provincial y municipal), y páginas web, blogs o redes sociales de proyectos, programas y fundaciones, entre otras. Y finalmente, comunicaciones con las municipalidades de los 24 partidos - de forma personal, telefónica y/o vía correo electrónico-, y con responsables de proyectos de orquestas privadas y del tercer sector a fin de corroborar o corregir la información obtenida a través de medios de comunicación y de conversaciones informales - de forma personal, telefónica y/o correo electrónico-.Todos los interlocutores recibieron un cuadro preliminar de proyectos de orquestas infantiles y juveniles en el GBA, lo que contribuyó a facilitar el proceso de verificación y corrección de la información recabada. En muchos casos volvimos a contactar a los responsables de proyectos o programas, así como a referentes municipales, a fin de corroborar la validez de los datos recabados y ofrecer instancias de diálogo para eventuales revisiones previas a su publicación. Esta estrategia metodológica nos permitió profundizar, corregir y clarificar la información rastreada por diferentes medios. Adicionalmente, elaboramos un dispositivo que permite que la matriz de datos resultante de esta investigación esté a disposición de la comunidad académica, las instituciones 
gubernamentales, los gestores, los docentes, los coordinadores y las comunidades destinatarias de los proyectos o programas. Este dispositivo fue especialmente diseñado como herramienta interactiva, con acceso libre y gratuito a través de una página web: http:// musicainclusion.silk.co/.

En el marco de este proyecto se desarrollaron también actividades no previstas en la formulación inicial, que contribuyeron a alcanzar los objetivos adicionales buscados por este equipo: favorecer la visibilidad y valorización de los proyectos de orquestas infantiles y juveniles, y propiciar la reflexión y discusión sobre sus dinámicas de funcionamiento. Entre ellas destacamos la organización y coordinación de Mesa Redonda "Los proyectos y programas de Orquestas Infantiles y Juveniles” en el marco del Día Nacional de la Gestión Cultural (16 de octubre de 2015, Universidad Nacional de Avellaneda) ${ }^{7}$.

En el rastreo realizado hemos hallado que, a finales del 2015, en el Gran Buenos Aires funcionaban 116 orquestas ( 36 de ellas ubicadas en la Ciudad Autónoma de Buenos Aires y 80 distribuidas en los partidos del Gran Buenos Aires) ${ }^{8}$. Aunque no desarrollaremos aquí un análisis de los resultados alcanzados (ver Avenburg, Cibea y Talellis, 2017), nos limitamos a notar que, si bien los diversos proyectos de orquestas tienen ciertas características afines generadas por su dimensión social y por el enfoque en la formación musical a través de la práctica orquestal, al mismo tiempo presentan numerosas diferencias. Por ejemplo, en cuanto a los modelos de políticas, los diseños de gestión, las inserciones institucionales, los modos de financiamiento, las modalidades de organización, las actividades que efectúan, los instrumentos musicales que emplean, el repertorio que incluyen, las perspectivas que sustentan, las valoraciones estéticas que manifiestan, las interpretaciones que realizan y las poblaciones que abarcan, entre otras.

\section{La investigación y la gestión cultural: posibles cruces}

Como plantea Novaro (2010), en ocasiones se suele pensar que entre la investigación y la gestión existen diferencias abismales. A la vez, sostiene que todavía hay una fuerte creencia instalada en los ámbitos académicos según la cual la investigación se refiere a lo crítico y analítico, mientras que la gestión (tanto de nivel público, privado o del tercer sector) se relaciona con actividades de tipo propositivo y de intervención. En consecuencia, también en el campo cultural observamos que, por un lado, el diseño de una investigación no considera necesariamente incluir las miradas, las necesidades y/o las inquietudes de los gestores culturales; y por el otro lado, los diseños de políticas, programas y proyectos en el campo cultural no siempre tienen en cuenta el valor de investigar en profundidad en territorio para elaborar un diagnóstico' ${ }^{9}$. Contrarias a este prejuicio, coincidimos con la autora cuando sostiene que suponer que una investigación es ajena a las emergencias y que la gestión no contempla espacios de reflexión y de crítica supone una mirada sesgada y limitada de ambas prácticas (Novaro, 2010). A su vez, Moreno Pestaña y Espadas Alcazar (S/D) resaltan la importancia de lo que ellos denominan "Investigación Acción Participativa", entendida como herramienta de acción para transformar realidades. Central en ella es la participación de la comunidad a analizar, es decir que sus integrantes son sujetos protagonistas; se trata de un modo de investigación que busca entender el mundo mientras lo cambia. 
Sostenemos entonces que, aunque se trata de dos campos con sus propias características, también pueden converger en espacios donde la reflexividad y la emergencia están presentes, y donde las discusiones conceptuales y el propio desarrollo de la práctica se encuentren fortalecidos. Si bien la investigación se caracteriza por la progresiva rigurosidad en el uso de los conceptos de manera tal que requiere de tiempos que no siempre se corresponden con los de la gestión, consideramos que esa práctica constituye un elemento propiciador de instancias de reflexividad que pueden articularse de manera eficiente con lo que respecta al diseño, desempeño y evaluación de la gestión.

La construcción de una relación dialéctica entre la gestión y la investigación es importante en todas las áreas de actividad, y esta necesidad se hace evidente en el campo de las políticas culturales y de la gestión cultural. Como definen Olmos y Santillán Güemes (2004), la gestión cultural se ocupa específicamente de crear, dar origen, generar, así como de ejecutar un proyecto, plan, programa o política concerniente al "sector cultura". Este último refiere al "campo de lo cultural", esto es, el conjunto de actividades y producciones simbólicas que desarrollan algunos elementos de la "cultura integral", lo que significa que por lo general se trata de un recorte de la cultura entendida en su sentido amplio (Santillán Güemes, 2000). En nuestro trabajo es útil enfatizar que la cultura está en movimiento y es indisociable del entramado social y político; siguiendo a Wright (1998), la entendemos como proceso continuo de construcción y disputa de significados.

Dentro de este marco conceptual y en línea con Martinell (2000) notamos que los proyectos y las políticas en el campo de la cultura por un lado tienen sus propias especificidades, y por el otro lado no se pueden aislar de los otros aspectos y políticas generales de la sociedad. La primera observación se refiere a que, a diferencia de la gestión genérica de cualquier sector productivo, para la gestión en el campo cultural se necesita "entender los procesos creativos y establecer relaciones de cooperación con el mundo artístico y sus diversidades expresivas" (Martinell, 2001, p. 12). La segunda observación remite a las sinergias que la cultura mantiene con los procesos sociales más amplios. Por esta razón, para el diseño de las políticas culturales se vuelve imprescindible tener tanto la capacidad de estudio y análisis de los aspectos globales de las políticas públicas, como la posibilidad de interlocución con otras políticas sectoriales. Según Martinell (2000, p. 10), esto requiere de "dinámicas de codificación y descodificación que permitan situar las políticas culturales en un panorama más amplio"; "un aumento considerable de reflexiones sobre el papel de los diferentes agentes, así como sobre las estrategias para la integración de las políticas culturales en el conjunto de la acción pública"; “ "una mayor información sobre el contexto que envuelve los procesos de elaboración y toma de decisiones".

Podemos concluir que, en el sector cultural, gestionar requiere tener "una sensibilidad de comprensión, análisis y respeto de los procesos sociales en los que la cultura mantiene sinergias importantes", así como valorar

Los intangibles y asumir la gestión de lo opinable y subjetivo, circulando entre la necesaria evaluación de sus resultados y la visibilidad de sus aspectos cualitativos. La gestión de la cultura debe entonces encontrar unos referentes propios de su acción, adaptarse a sus particularidades y hallar un modo de evidenciar, 
de forma muy distinta, los criterios de eficacia, eficiencia y evaluación. (Martinell, 2001, pp. 12-13)

Siguiendo estas perspectivas, creemos que el desarrollo de una investigación que posibilite acercarse a las experiencias socioculturales de los diferentes grupos, puede contribuir a la gestación de esa sensibilidad, a la posibilidad de esa adaptación a la que hacen referencia los autores. En definitiva, este es el eje alrededor del cual buscamos continuamente diseñar y re-diseñar nuestra investigación, entendiendo el rol crucial que la investigación sociocultural puede cumplir en los procesos de cambio y transformación social. Nuestra intención es que la investigación responda no solamente a inquietudes de orden teórico, sino que también esté articulada a necesidades identificadas por los mismos actores sociales y gestores culturales. Esto implica la construcción de una relación basada en la confianza y la reciprocidad, que habilite la reflexión conjunta y que incluya la devolución del material producido a los participantes del proceso de investigación.

\section{Diseñando articulaciones: estrategias de diálogo entre la investigación y la gestión}

En el desarrollo de nuestra investigación las estrategias metodológicas fueron especialmente diseñadas para generar instancias de cruce entre la investigación y los distintos agentes de gestión (pública, privada y del tercer sector) de los programas y proyectos de orquestas infantiles y juveniles que se desarrollan en el Gran Buenos Aires. A continuación queremos destacar tres de estas instancias: la realización de entrevistas y charlas conceptuales de forma reiterada; la sistematización de la información recabada en una matriz interactiva de datos y su publicación en una página web de acceso libre y gratuito; y la organización de una mesa redonda con referentes de diversos proyectos y programas de orquestas.

En primer lugar, el hecho de realizar entrevistas semi estructuradas y conversaciones distendidas -en ocasiones de forma reiterada- con algunos referentes, nos posibilitó mantener charlas y discusiones con nuestros entrevistados. En este sentido, poder discutir sobre algunos conceptos o sobre la misma práctica -como por ejemplo sobre inclusión, la población destinataria, o la disponibilidad de recursos necesarios para llevar adelante una acción-, fueron construyendo espacios de intersección con un ida y vuelta entre los dos ámbitos, el de la investigación y el de la gestión. En estos espacios vislumbramos la problematización, por parte de los gestores, de ciertas temáticas como la de inclusión, selección de repertorio, elección de la población destinataria, como también sobre las orientaciones simbólicas que cada propuesta persigue en su implementación. Asimismo, el entrevistar a distintos referentes de proyectos nos permitió develar un campo heterogéneo y variable que constituye un rico campo de disputas simbólicas. La posibilidad de diálogo contribuyó al análisis, todavía en curso, de las distintas acepciones que se dan a los conceptos desde diferentes programas o proyectos, así como al reconocimiento de su elasticidad y su potencialidad. Pero además, las perspectivas e inquietudes de nuestros interlocutores contribuyeron no solo a conformar nuestro campo empírico sino también a ampliar nuestras 
discusiones teóricas. Con esto queremos decir que los entrevistados no son meros "proveedores de datos empíricos" sino interlocutores que producen conocimiento junto con los investigadores. Esto es válido -en nuestra opinión- para toda investigación social. En este caso concreto, se traduce en que la investigación requiere del diálogo con la práctica de la gestión para construir y discutir sus marcos conceptuales. Como contraparte, es nuestro deseo que las mismas discusiones conceptuales -y desde ya, el material producido a partir de ellas- puedan ser de utilidad para revisar, reafirmar o modificar la práctica de la gestión. Es necesario aclarar que en el trabajo de campo no es siempre sencillo llevar adelante el tipo de articulación que proponemos -es decir, no solo depende de la voluntad de los investigadores-. En una coyuntura política compleja como aquella en la cual se insertan los proyectos y programas de orquestas infantiles y juveniles, fueron las relaciones interpersonales previas las que facilitaron nuestro acceso al campo.

En segundo término, la propuesta de sistematizar la información en una matriz de datos con un formato de fácil lectura, accesible para visualizaciones y usos interactivos, fue muy bien recibida. Ello posibilitó tener una mirada transversal de las diferentes orquestas combinando los distintos patrones de consulta del dispositivo. Algunos programas incluso destacaron la necesidad de tener la información organizada de esa manera para poder pensar cuestiones puntuales de cada programa en función del universo reflejado. $\mathrm{Al}$ mismo tiempo, la creación de la herramienta de consulta online permitió también dar visibilidad al alcance de su trabajo. Destacar los distintos objetivos, repertorio, poblaciones destinatarias, articulaciones institucionales, etc., posibilita la reflexión tanto del investigador como del gestor en función de las heterogeneidades de propuestas y de sus posibles acercamientos o discrepancias. Pues fue gracias a la información sistematizada que pudimos vislumbrar que, incluso dentro de un mismo nivel gubernamental, se despliegan distintas modalidades de gestionar acciones sobre propuestas que comparten un denominador común.

Finalmente destacamos el valor de poder compartir los avances de la investigación en una mesa redonda organizada por el equipo y de la que participaron referentes de diversos proyectos/programas de orquestas. Allí se expusieron los avances del trabajo realizado hasta el momento, abriéndolos a preguntas, comentarios y en general a la devolución de los mismos actores sociales. Pero el objetivo central de la mesa fue la generación de un espacio donde cada referente de los distintos proyectos/programas -fueran de gestión pública, privada o del tercer sector-, pudiera presentar y poner en diálogo sus proyectos, concepciones, modos de implementación, poblaciones destinatarias, selección de repertorio, articulaciones institucionales, pedagogías de enseñanza musical, orientaciones simbólicas de sus políticas, etc. Se discutió también la diferencia entre concebir esos proyectos como derechos culturales o instrumentos paliativos, entre otras cosas. Se buscó así dar forma a un espacio de discusión en el que los diferentes integrantes de proyectos/programas pudieran encontrar en ese espacio de diálogo la posibilidad de realizar una reflexividad conceptual compartida y establecer debates acerca de las distintas orientaciones simbólicas en disputa. Al mismo tiempo, estas reflexiones y debates conceptuales fueron incorporadas como material de análisis discursivo en la investigación. 


\section{Conclusiones}

En este trabajo nos propusimos compartir una serie de reflexiones a partir de nuestra experiencia de investigación sobre los proyectos y programas de orquestas infantiles y juveniles que funcionan en el Gran Buenos Aires. Nos centramos especialmente en torno a tres estrategias concretas de diseño de investigación que nos permitieron crear espacios de diálogo con la gestión, lo que facilitó la articulación entre los dos campos en un marco de independencia y confianza recíproca. De esta forma buscamos pensar sobre la articulación entre cultura y diseño desde un cruce particular: por un lado, remarcamos la importancia de la investigación sociocultural para el diseño de políticas, programas y proyectos en el campo cultural; y por el otro lado, subrayamos la centralidad del diálogo con el campo de la gestión cultural a la hora de diseñar una investigación.

La construcción de una herramienta de consulta online sobre las orquestas infantiles y juveniles del Gran Buenos Aires con información sistematizada, la realización de entrevistas y discusiones conceptuales de forma reiterada, y la organización de una mesa redonda con referentes de diferentes proyectos y programas de orquestas fueron formas concretas en las cuales hemos generado articulaciones desde la investigación con la gestión, a fin de contribuir a las políticas culturales desarrolladas. Consideramos que estas modalidades de relacionar los dos campos -y otras similares-, favorecen el camino hacia la comprensión de las políticas culturales y permiten la posibilidad de, en un futuro, atender a la relación entre sus objetivos, las modalidades de políticas que despliegan para lograrlos, y las experiencias concretas que se generan entre sus participantes.

Asimismo señalamos que desde la investigación pretendemos que nuestra tarea no circule solamente en el ámbito académico como si se tratara de un campo cerrado, sin articulaciones con $-y$ contribuciones a- la práctica de la gestión. Desde el ámbito de la gestión, entendemos que es fundamental la posibilidad de reflexionar sobre estas prácticas, evaluarlas en profundidad y durante su mismo desarrollo, a fin de modificar, acentuar o revisar las acciones de intervención. El ámbito académico y el de la gestión no siempre están en diálogo; creemos que su vínculo es fundamental para enriquecer la gestión y para que la investigación contribuya a la práctica social. Valoramos la necesidad de comprender que las políticas culturales son un conjunto de intervenciones, acciones y estrategias que distintas instituciones gubernamentales, no gubernamentales, privadas y comunitarias llevan a cabo para:

Satisfacer las necesidades y aspiraciones culturales, simbólicas y expresivas, de la sociedad en sus distintos niveles y modalidades (...) [y que ello requiere] tener en cuenta y conocer la variedad cultural de los destinatarios, la complejidad del territorio y su gente, la multiplicidad de instituciones (oficiales, privadas, comunitarias, asociaciones intermedias) que interactúan. (Olmos, 2007, p. 1)

En nuestra opinión, la investigación sociocultural -en particular el enfoque etnográfico- puede contribuir a acercarse a las miradas y experiencias de los actores sociales. En sintonía con Olmos, entonces, buscamos que los puntos de articulación aquí desarrolla- 
dos posibiliten pensar en el diseño de la gestión en el campo cultural en diálogo con la investigación, y en el diseño de los proyectos de investigación social articulados -críticamente- con la gestión.

\section{Notas}

1. Una versión preliminar de este artículo fue presentada en el $2^{\circ}$ Congreso Nacional de Gestión Cultural. Santiago de Chile, 24 al 26 de noviembre de 2016.

2. En los años ' 90 en gran parte de América Latina se implementaron políticas de desregulación económica, ajuste fiscal, privatizaciones, desindustrialización, concentración, expulsión del mercado laboral de gran cantidad de personas, degradación en las condiciones de vida de los sectores populares y de clase media, y reducción de políticas sociales, entre otras cosas (Kliksberg 2014, Pérez Rubio 2006, Villarreal 1996).

3. Las culturales no son las únicas políticas que han abordado esta temática. A los efectos del presente trabajo y como se verá más adelante, sin embargo, nos centramos en la dimensión cultural ya que nos interesa focalizar en la orientación y distinciones simbólicas de determinadas políticas.

4. La investigación fue realizada por el Grupo de Investigación sobre Música e Inclusión, radicado en la Universidad Nacional de Avellaneda. Es un equipo interdisciplinario conformado por las investigadoras Karen Avenburg, Alina Cibea, Verónica Talellis, Gabriela Barro Gil, Gladys Giliberti y Elsa Martínez (quienes realizamos dicha investigación), además de Eugenia Amantía y Paula Vilas (quienes se sumaron posteriormente).

5. Este trabajo se inició en el año 2014 como un proyecto de investigación PROAPI financiado por la Universidad Nacional de Avellaneda y continuó en el año 2015 gracias al apoyo y financiamiento del Instituto de Cultura Pública del Ministerio de Cultura de la Nación. Para el periodo 2016-2017 el proyecto cuenta con una financiación UNDAVCyT. 6. Almirante Brown, Avellaneda, Berazategui, Esteban Echeverría, Ezeiza, Florencio Varela, General San Martín, Hurlingham, Ituzaingó, José C. Paz, La Matanza, Lanús, Lomas de Zamora, Malvinas Argentinas, Merlo, Moreno, Morón, Quilmes, San Fernando, San Isidro, San Miguel, Tigre, Tres de Febrero y Vicente López.

7. En esa mesa, representantes de diversos proyectos o programas relataron el proceso de creación, el desarrollo y las dinámicas cotidianas que implican gestionar este tipo de iniciativas. Se propició particularmente la puesta en diálogo de los alcances y dificultades que encuentran en su puesta en práctica, discutiendo y reflexionando acerca de las diferentes propuestas y modalidades de acción.

8. Es menester destacar, en función del dinamismo y los cambios coyunturales que atraviesan a las políticas culturales, que este panorama se modificó en el periodo siguiente.

9. En particular creemos que la perspectiva etnográfica tiene mucho para aportar en el acercamiento a las realidades locales y sus múltiples modalidades de interpretación; la etnografía como enfoque, dice Guber (2012, p. 16), "constituye una concepción y práctica de conocimiento que busca comprender los fenómenos sociales desde la perspectiva de sus miembros". 


\section{Referencias Bibliográficas}

Avenburg, K, Cibea, A, y Talellis, V. (2017). “Las orquestas infantiles y juveniles del Gran Buenos Aires. Estudio descriptivo del panorama de proyectos y programas vigentes entre 2014 y 2015”. En Foro de educación musical, artes y pedagogía, Vol. 2 (Núm. 2): 13-57.

Avenburg, K.; Cibea, A.; Talellis, V.; Barro Gil, G.; Giliberti, G. y Martínez, E. (2015) .Publicación online de "Rastreo de los Proyectos de Orquestas Infantiles y Juveniles del Gran Buenos Aires (Argentina)”. http://musicainclusion.silk.co/.

Barbieri, N, Partal, A y Merino, E. (2011). "Nuevas políticas, nuevas miradas y metodologías de evaluación. ¿Cómo evaluar el retorno social de las políticas culturales?”. En Papers Revista de Sociología 96 (2): 477-500.

Bayardo, R. (2000). “Antropología, Identidad y Políticas Culturales”. En NAYA (Noticias de Antropología y Arqueología). Disponible en: http://www.naya.org.ar/articulos/identi01. htmhttp://www.naya.org.ar/articulos/identi01.htm.

Belfiore, E. (2002). "Art as a means of alleviating social exclusion: Does it really work? A critique of instrumental cultural policies and social impact studies in the UK". En International Journal of Cultural Policy 8 (1): 91-106.

Belfiore, E. (2006). “The social impacts of the arts - myth or reality?”. En Mirza, M. (ed.) Culture Vultures: is UK arts policy damaging the arts? London: Policy Exchange Limited. Pp. 20-37. Disponible en: http://wrap.warwick.ac.uk/51721/1/WRAP_Belfiore_Social _impacts_arts_ExtractPage2.pdf.

Castel, R. (1997). La metamorfosis de la cuestión social. Paidós: Buenos Aires.

Fitoussi, J-P y Rosanvallon, P. (1997). La Nueva Era de las Desigualdades. Buenos Aires: Manantial.

García Canclini, N. (1987). "Políticas culturales y crisis de desarrollo: un balance latinoamericano”. En García Canclini (ed.), Políticas culturales en América Latina. México: Grijalbo. Pp. 13-53.

Guber, R. (2012). La etnografía. Método, campo y reflexividad. Bogotá: Grupo Editorial Norma.

Kliksberg, B. (2014). Otra economía es posible. Desde el consenso de Washington a la visión de una nueva economía IV. Buenos Aires: La Página.

Martinell, A. (2000). “Agentes y Políticas Culturales. Los Ciclos de las Políticas Culturales”. Sin datos. Disponible en: http://sgpwe.izt.uam.mx/files/users/uami/nivon/MARTINELL _agentes_y_politicas_culturales.pdf (Último acceso: 27-11-15).

Martinell, A. (2001). Singularidad profesional y perspectivas de futuro (Recopilación de textos). Cátedra Unesco de Políticas Culturales y Cooperación. Disponible en: http://www. cidadeimaginaria.org/gc/GCprofut.pdf (Ultimo acceso: 28-6-17).

Moreno Pestaña, J. y Espadas Alcázar, M. (S/D). Investigación - Acción participativa.

Muiños de Britos, S.M. (2010). "La práctica musical colectiva. Aprendizaje artístico y social". En Revista Iberoamericana de Educación $\mathrm{N}^{\circ}$ 52/2. Disponible en: http://www.rieoei.org/ deloslectores/3589Muinos.pdfhttp://www.rieoei.org/deloslectores/3589Muinos.pdf.

Novaro, G. (2010). “Intersecciones entre la investigación y la Gestión. Avances en el Campo de la Antropología y la Educación. En PUBLICAR - Año VIII No IX. 
Olmos, H. A. (2007). "Políticas Culturales para la inclusión Democrática". S/D. Disponible en: https://es.scribd.com/document/187267436/2-Politicas-Culturales-Para-LaInclusion-Democraticas

Olmos, H. A. (2008). Gestión cultural e identidad: claves del desarrollo. Madrid: Agencia Española de Cooperación Internacional para el Desarrollo.

Olmos, H. A. y Santillán Güemes, R. (2004). "La gestión cultural y la construcción de poder. El mundo en gestión”. Conferencia Magistral presentada en el Primer Encuentro Nacional de Promotores y Gestores Culturales. 23 al 26 de junio. Ciudad de Zacatecas.

Pérez Rubio, A. M. (2006). "Acerca de la exclusión y otras cuestiones próximas". Revista de Estudios Regionales, y Mercado de Trabajo 2. Disponible en: http://www.simel.edu.ar/ archivos/documentos/RS2\%20Rubio.pdf.

Raggio, L. (2013). "Los derechos culturales en la Ciudad Autónoma de Buenos Aires: una contienda simbólica en pleno desarrollo". En Cuadernos de Antropología 10: 277-297.

Santillán Güemes, R. (2000). "El campo de la cultura”. En Olmos, H. y Santillán Güemes, Educar en Cultura, ensayos para una acción integrada. Buenos Aires: CICCUS.

Villarreal, J. (1996). La exclusión social. Buenos Aires: Grupo Editorial Norma.

Wald, G. (2009). "Los dilemas de la inclusión a través del arte: tensiones y ambigüedades puestas en escena”. En Revista Oficios Terrestres 24: 53-63. Facultad de Periodismo y Comunicación Social, Universidad Nacional de La Plata.

Wright, S. (2010). "La politización de la 'cultura", en Boivin, M., Rosato, A. y Arribas, V. Constructores de Otredad. Una introducción a la Antropología Social y Cultural, Buenos Aires: Antropofagia. Pp. 156-172.

Yúdice, G. (2002). "El recurso de la cultura”. En El recurso de la cultura. Usos de la cultura en la era global. Barcelona: Gedisa. Pp. 23-55.

\begin{abstract}
A large number of projects and programs for children and youth orchestras are initiatives that develop musical education through orchestral training, focusing on populations in vulnerable situations. In the this article we present a series of reflections on the basis of an investigation carried out between 2014 and 2015, which mapped the projects and programs of orchestras that function in Gran Buenos Aires (Argentina). We especially intend to discuss some issues that we recognized in the ethnographic practice as valuable intersections between cultural management and socio-cultural research. We thus expose a research experience that seeks to be designed (and redesigned) from a dynamic articulation with actors from the cultural management field; we also believe that research can be a valid tool for design and evaluation in the cultural management field.
\end{abstract}

Key words: children and youth orchestras - cultural management - sociocultural research.

Resumo: Uma grande quantidade de projetos e programas de orquestras infantis e juvenis representam iniciativas que desenvolvem o ensino musical através da formação orquestral com foco nas populações em situação de vulnerabilidade. Neste artigo apresentamos algumas reflexões em base a pesquisas realizadas em 2014 e 2015 sobre os projetos e pro- 
gramas de orquestras que atuam no Gran Buenos Aires (Argentina). Procuramos discutir especialmente alguns aspectos que nas etnografias se apresentam como novos canais de diálogo e reflexão para pensar em cruzamentos e intersecções entre gestão cultural e investigação sociocultural. Queremos, então, apresentar uma experiência de pesquisa que busca projetar-se (e redesenhar-se) a partir duma ligação dinâmica com a mesma gestão; consideramos também que as investigações podem tornar-se ferramentas válidas para a concepção e avaliação no domínio da gestão cultural.

Palavras chave: orquestras infantis e juveniles - gestão cultural - pesquisa sociocultural. 

Fecha de recepción: marzo 2017 Fecha de aceptación: octubre 2017 Versión final: marzo 2019

\section{Wright Mills y su crítica al diseño de segunda posguerra. Los aportes de la sociología al mundo del diseño}

Verónica Paiva * y Alejo García de la Cárcova ${ }^{\star *}$

Resumen: El artículo profundiza sobre dos textos elaborados por el sociólogo Charles Wright Mills en donde critica la posición que tomó el diseño industrial desde la crisis del '29 y en especial desde la Segunda Posguerra. El autor reprocha a los diseñadores industriales haber dejado su rol como parte del aparato cultural para ser miembro del aparato comercial, al prestar sus conocimientos sobre arte y diseño a la gran industria. Desde la crisis de sobreproducción del '29 el capitalismo se dinamizó a través del consumo masivo y la obsolescencia programada es decir, del desgaste de los objetos por cuestiones de prestigio o moda. En esa tarea el diseñador fue un engranaje indispensable al generar nuevas estéticas que promueven el cambio de moda o al vincular los objetos al status socioeconómico. Por esa razón Wright Mills invita a los diseñadores, arquitectos, paisajistas, planificadores urbanos, a volver a pensar su lugar social y promover políticas que contribuyan al bienestar humano.

Palabras clave: Diseño - Estética - Teoría Sociológica - Consumo Masivo - Obsolescencia Programada.

[Resúmenes en inglés y portugués en la página 117]

(*) Licenciada en Sociología y Doctora de la Universidad de Buenos Aires, Área Ciencias Sociales. Es docente e investigadora de la Facultad de Arquitectura, Diseño y Urbanismo de la Universidad de Buenos Aires e investiga en temas de hábitat y diseño. Dirige proyectos de investigación UBACyT desde el año 2003 y es Docente Investigadora categoría II del Programa de Incentivos Docentes del Ministerio de Educación de la Nación. Dicta clases de metodología en el Doctorado en Diseño de la UP.

${ }^{(*)}$ Diseñador Industrial (ORT). Carrera de Formación Docente (FADU/UBA). Docente FADU/UBA y ORT. Se desempeña en el área de Posgrados y Publicaciones Académicas de la Facultad de Diseño y Comunicación y forma parte del Equipo de Evaluación de los Proyectos de Graduación (Universidad de Palermo). 


\section{Introducción}

Este artículo se inscribe en una línea de investigación que estudia los aportes de la sociología a los estudios visuales ${ }^{1}$ y del diseño. Si bien se trata de un campo de reciente formación lo cierto es que la imagen ha sido terreno de investigación sociológica desde hace muchos años a través de autores como Howard Becker (1974), Ervin Goffman (1976), Pierre Bourdieu (1965) o Jean Baudrillard (1968), mientras que el rol del diseño en el consumo fue materia de reflexión desde las ciencias sociales, a través de autores como Lipovetsky (1990) en sus trabajos sobre el consumo en la posmodernidad.

A pesar de este recorrido, no existen demasiados estudios que se hayan detenido en la interrelación entre la sociología y la visualidad, y menos aún en el cruce entre la sociología y el diseño, por lo cual, este trabajo aborda un texto de Wright Mills referido a los diseñadores que es muy poco conocido dentro de los estudios sociológicos y del diseño.

Nuestro interés radica en realizar un recorrido histórico por el pensamiento de este autor y desde allí detenernos en los aportes de la sociología a los estudios visuales y/o del diseño $y$, al revés, sobre el aporte del diseño al pensamiento sociológico. En términos más amplios, reflexionaremos en las relaciones entre cultura y diseño.

\section{Charles Wright Mills. Biografía y textos clave}

Charles Wright Mills fue un sociólogo estadounidense nacido en 1916 y muerto en 1962. Para cualquiera que haya estudiado sociología es un referente indiscutido al definir "la imaginación sociológica" como la cualidad mental que permite cruzar "biografía e historia" y dar cuenta de la especificidad de la mirada sociológica que es aquella que puede explicar lo individual por lo social y lo social en lo individual.

Entre las obras fundamentales de Wright Mills se cuentan Los nuevos hombres del poder: los dirigentes laborales americanos (1948), Cuello blanco: las clases medias en Norteamérica (1951), La élite de poder (1957) La imaginación sociológica (1959) o Escucha, yanqui: la revolución en Cuba (1960).

El ambiente social, político e intelectual que rodeó a Mills fue la sociedad de consumo y la cultura de masas, el ascenso de la sociedad de la información, la Guerra Fría, la revolución cubana y las características de la élite de poder en Norteamérica. Intelectual y teóricamente se trató de un pensador independiente que si bien retomó la línea interpretativa de Marx y de Weber, la reformuló para poder interpretar los problemas de la etapa en la que vivió. Fue un crítico furioso de Talcott Parsons y "su gran teoría" y a nivel político reprobó tanto a Estados Unidos como a la Unión Soviética. Además del funcionalismo, el ambiente teórico con el que convivió fue el crecimiento de los estudios sobre mass media de Merton y Lazarsfeld, como así también los sondeos de opinión pública y de consumo masivo que proliferaron con el desarrollo de la técnica estadística a partir de los trabajos de Lazarsfeld. Entre todos sus estudios Wright Mills tiene algunos referidos a los diseñadores y su lugar en el aparato cultural de la época. Se trata de estudios poco conocidos en la teoría sociológica de los que daremos cuenta en los puntos siguientes. 


\section{Wright Mills y los diseñadores}

En 1958 y 1959 Wright Mills dio dos conferencias en Aspen y Toronto, donde se refiere a las particularidades del diseño y del diseñador en la sociedad estadounidense de esa época. Tal como comenta Javier Treviño (2014), Mills no sólo tenía una vocación especial y personal por el arte, sino que el mismo desarrollaba actividades de fotógrafo, constructor y artesano en su tiempo libre, razón por la cual, la temática del diseño no le era ajena.

Una de ellas fue en 1958 en la Eight International Design Conference, en la que presentó el trabajo "El hombre en el medio. El Diseñador" en donde señala el lugar complejo y contradictorio que ocupan los diseñadores en la sociedad de consumo. Su trabajo tiene tres objetivos: describir las características del aparato cultural, indicar el contexto económico en que trabaja el diseñador e incitarlo a reconsiderar los ideales con los que desarrolla su tarea. En cuanto al aparato cultural, se trata de las organizaciones y medios donde se realiza la labor artística, científica e intelectual, como así también los canales por los cuales esa labor llega al público masivo. El diseño y el arte son parte del aparato cultural, así como los museos, los medios masivos de comunicación y todas las instituciones por donde circulan los productos culturales. Tal como señala Mills, el mundo no se percibe de modo neutro, sino con un significado elaborado por otros, que se adquiere en el proceso de vivir. En ese mundo de significados, los objetos y las imágenes ocupan un lugar central, no son neutras, sino plenas de sentido.

Como manifiesta Mills, desde la crisis de sobreproducción de la década de 1929 el capitalismo se reactivó a partir de la implementación de tres tipos de obsolescencias de los objetos: el desgaste tecnológico debido al paso del tiempo, el recambio porque "debe desgastarse" y el recambio por prestigio, es decir, la aparición de una nueva moda que impulsa al consumidor a deshacerse del antiguo objeto, a pesar de que su funcionamiento esté intacto. Con voz crítica, Mills señala que en esta nueva tesitura de acelerar el desgaste por moda o prestigio, el diseñador dejó de trabajar en el aparato cultural para ser parte del aparato comercial y agregar valor estético superfluo a los objetos, convirtiéndose, en muchos casos, en mero auxiliar de los empresarios e industriales. Por esa razón, Mills exhorta a los diseñadores a volver a ser parte del aparato cultural y a los valores de la artesanía y el artesano, es decir, a la fabricación de objetos que se realizan por el sólo placer de hacerlos y sobre los cuales el artesano conoce todo el proceso, sin la enajenación de vender el arte a los intereses de la industria del momento. (Wright Mills, 2008)

Posteriormente, en la conferencia brindada en Toronto en 1959, Wright Mills se refirió a las ciudades y el modo de vida surgido en ellas después de la Segunda Guerra Mundial. Las ciudades son grandes monstruos que crecieron sin planificación con gente atrapada en su interior. Los suburbios no son mejores, con personas que repiten rutinas, trabajos y conductas no creativas sin cuestionarse si existe otro modo de vivir. Al decir de Mills, estas personas toman ese orden como natural y no poseen la imaginación sociológica que les permitiría analizar las fuerzas estructurales que condicionan su carácter, que se relacionan, sin duda, con el valor que han tomado los bienes raíces en la acumulación capitalista. En ese recorrido los diseñadores, los arquitectos, los planificadores urbanos, los paisajistas y los publicistas sometieron su arte al capital sin dar un debate sobre la política estética dirigida a las grandes áreas urbanas, en pos de mejorar la calidad de vida humana. 
Es que, como bien señala Javier Treviño (2014), en la época en que Wright Mills escribe sus escritos, se desarrollaron los primeros suburbios del tipo "Levittowns", es decir, vecindarios ubicados en las afueras de la ciudad, construidos con viviendas de tipología similar y habitadas por una clase media en ascenso, con rutinas de vida parecidas, gustos parejos, pasatiempos y conductas recreativas homogéneas, socialmente conformistas y políticamente indiferentes. Se trataba de la clase media surgida con el crecimiento de la sociedad de consumo y la expansión del american way of life. La sociología criticó este estilo de vida a través de autores como el propio Mills. Desde el urbanismo, este modo de vida fue abordado y criticado por Lewis Mumford en su libro La ciudad en la historia (1961) sobre el que Wright Mills escribió una reseña llamada The way to necrópolis (Treviño, 2014, pp. 350-351).

\section{La Sociedad de Consumo}

Se trata del tipo de sociedad que emerge luego de la Segunda Revolución Industrial, en la cual el consumo se convierte en el gran dinamizador de la industria y el articulador de las relaciones humanas.

En la primera etapa del capitalismo, la modalidad central se basaba en la producción consumo. Sin embargo, este modelo se agota rápidamente ya que la cantidad de productos que generaban las máquinas era muy superior a la que podía comprar y consumir la población. La primera gran crisis del capitalismo se produjo en 1873 a partir de una baja general de precios producida por la mejora en los transportes y la aparición de nuevos mercados en las colonias europeas. El capitalismo salió de esta crisis con medidas proteccionistas sobre los productos nacionales, la aparición de nuevos mercados y las nuevas técnicas y fuentes de energías de la Segunda Revolución Industrial.

La segunda gran crisis -la Gran Depresión del '29- fue generada, entre otras causas, por la sobreproducción de objetos a los que la gran mayoría de la población no podía acceder debido a sus bajos salarios.

Si bien la salida de esta crisis es muy conocida, vale la pena volver a reseñarla: políticas keynesianas, taylorismo, fordismo, obsolescencia programada y consumo de masas.

El New Deal (Nuevo Trato) firmado por Roosevelt en 1933 implicó la puesta en marcha de las políticas keynesianas orientadas a motorizar la economía a través del aumento de salarios, la intervención del estado en la obra pública, la dinamización de la industria, y el consumo de masas.

El método de trabajo en serie de Taylor (1900) se activó con el fordismo a través de la cadena de montaje y la estimulación del consumo. En definitiva, Ford fabricaba los autos que consumirían sus propios obreros (Carosio, 2008).

Este maridaje entre consumo, políticas keynesianas, intervención estatal y altos salarios continuó durante el período posterior a la Segunda Guerra Mundial, a través del esquema del Estado de Bienestar y las altas tasas de crecimiento económico sostenidas al ritmo de la industria automotriz, los bienes de consumo y el transporte.

Pero todo este mecanismo no hubiera podido funcionar sin otro aspecto muy ligado a la producción y el consumo masivos: la obsolescencia programada. ¿De qué se trata? De 
provocar la renovación constante de los objetos para generar nuevos consumos, motorizar la economía y conservar los empleos e industrias.

Este modo económico productivo basado en el consumo masivo modeló un estilo de vida conocido como The american way of life o modo de vida estadounidense. A grandes rasgos, se trata de un estilo de vida basado en el consumismo, la necesidad constante de adquirir bienes materiales, el requerimiento del automóvil particular, la necesidad de cambiar los electrodomésticos por un modelo más nuevo, la comida elaborada, la creencia en que los logros económicos personales se deben totalmente al éxito individual, sin mediación alguna de políticas públicas.

La sociología y la filosofía criticaron duramente este perfil de sujeto modelado por el consumo a través de autores como Marcuse, Baudrillard o el propio Wright Mills. Y el diseño, ¿en cuánto contribuyó a acelerar el consumismo?

\section{El Diseño y el consumo masivo}

Desde la década de 1920 la producción industrial de objetos de consumo masivo dominará el mercado y el paisaje internacional. Y el estilo predominante al cual acudirá como respuesta de la crisis de 1929, una y otra vez y más que indiscriminadamente, será el streamline o estilo aerodinámico, "que plantea la forma de 'lágrima' como la que más se adaptaba al concepto de velocidad" (Gay, 2007, p. 155). Según Aquiles Gay:

La aerodinámica se aplicó también a objetos que no tenían porqué ser tenidos en cuenta como dinámicos y se popularizó tanto (...) que ha llegado a ser considerada como sinónimo del diseño industrial estadounidense de los años $30 \mathrm{y}$ 40. Cuando no está vinculado a la función, es una variante del styling y se pretende simbolizar, dinamismo, modernidad, velocidad (...). (Gay, 2007, p. 155)

El styling será la denominación general que se le asignará -a partir de la década del 30-a aquellos productos que irán modificando su apariencia -al igual que el ritmo de las temporadas en la moda de indumentaria- para poder generar el deseo de compra; sin considerar, la mayoría de las veces: ni el aspecto funcional del objeto, ni su caducidad. A partir de la creación en 1928 de la Sección de Arte y Color -por la General Motors, y bajo la dirección de Harley Earl- se aplicará este proceso de maquillaje en la industria automotriz, como puntapié para al resto de la producción de productos en serie. En 1938, esta sección pasará a denominarse Styling Section (Heskett, 1980). La más de las veces, el styling se vincula con la simple modificación de la parte exterior de un producto -denominado carcasa-cuando esta oculta o contiene las piezas mecánicas, por seguridad e higiene. Algunos de los primeros estilistas responsables de esta operación superficial, según varios historiadores o teóricos del diseño (Dorfles, Lucie-Smith, Bürdek) -y en algunas oportunidades denominados como "pioneros del diseño industrial norteamericano"- fueron: Raymond Loewy, Norman Bel Geddes, Henry Dreyfuss, Egmont Arens y Walter Dorwin Teague, entre otros; que eran contratados como consultores en las industrias. En ocasiones $-\mathrm{y}$ fuera 
del sector automotriz- se considera a Loewy, como el primero en recibir un encargo para realizar el carcaseo de una duplicadora, para la empresa Gestetner.

El segundo término emparentado con otro concepto funcional a la industria será el denominado obsolescencia programada, es decir, el diseño de productos destinados a caer en desuso en breve tiempo. Una de las primeras menciones a la obsolescencia programada la realizó el inversor inmobiliario Bernard London en 1932, quien propuso el vencimiento forzoso de los productos en una fecha determinada por ley y la entrega al gobierno para su destrucción (Dannooritzer, 2010). De hecho, uno de los primeros exponentes de la obsolescencia deliberada fue la bombita eléctrica, diseñada originalmente para durar más de 100 años. En 1924 se creó Phoebus, un grupo integrado por diversas compañías eléctricas, para intercambiar patentes, controlar la producción y reorientar el consumo. Se trataba de que los consumidores compraran bombitas periódicamente por lo que en pocos años la duración de estas pasó de 2.500 horas a 1.500 horas. En 1942 se habilitó una denuncia del gobierno de EE.UU. contra General Electric y sus socios pero, pese a la sentencia, las bombitas siguieron funcionando con una media de 1.000 horas (Dannooritzer, 2010).

En la década de 1950 se activó la propuesta de obsolescencia programada bajo otro concepto: convencer a los consumidores de la necesidad de renovar sus objetos periódicamente, activar el deseo permanente hacia productos nuevos y conjugar consumo, deseo y felicidad.

En esta propuesta, el marketing y la publicidad tuvieron un rol fundamental. En cuanto al marketing, desde 1950 se convirtió en impulsor de la industria, mientras que como disciplina mejoró su cuerpo teórico y técnico. Peter Drucker (1909-2005), el padre del marketing, afirmaba que: "cualquier empresa tiene dos y sólo dos funciones básicas: marketing e innovación" (1954). En cuanto a la publicidad, también se afirma durante estos años y de a poco pasará de la divulgación de las bondades del objeto a la propaganda de una serie de virtudes simbólicas que se asocian al consumo de ese objeto. El desarrollo de una parte de los estudios sociológicos de esa época, tal como los de Lazarsfeld en materia de opinión pública y mass media, así como los avances en métodos estadísticos, se usaron en marketing y publicidad. Baudrillard fue un crítico feroz de este tipo de publicidad que provoca que cada objeto que consumimos venga acompañado de su "doble publicitario", es decir, de un manto protector que nos protege frente a los imponderables de la vida diaria e incluso frente a las imperfecciones de los propios productos. "A través de la publicidad, como antaño a través de las fiestas, la sociedad exhibe y consume su propia imagen" (Baudrillard, 196; Caro Almela, 2007).

Acerca de los aspectos que puede presentar la obsolescencia programada, Charlotte y Peter Fiell (2006) mencionan las tres esferas que Vance Packard -feroz opositor a este conceptoidentifica en su libro de 1960: The waste makers. Allí, describe la dimensión de la obsolescencia funcional, donde un nuevo producto se propone al mercado como superador del anterior, la obsolescencia de calidad, que se relaciona directamente con la durabilidad del producto y la esfera de la obsolescencia por el deseo de obtener un producto más nuevo, más bello o más promocionado. En esta última esfera se apoya todo el concepto del styling. En relación a estos conceptos de obsolescencia programada y styling, Mills crítica el rol del distribuidor que: 
(...) es crear un volumen de masas de ventas continuas. La producción continua y expansiva requiere de un consumo continuado y expansivo, de modo que el consumo debe ser apresurado por todas las técnicas y fraudes del mercado. Además, las mercancías deben desgastarse más rápidamente (...). Es entonces cuando el desgaste se planifica y el ciclo económico se acorta deliberadamente. (Mills, 1958, p. 7)

En este contexto, durante las dos décadas previas a la Segunda Guerra Mundial, se terminará de delinear en Estados Unidos el rol del diseñador industrial. Un profesional "funcional a la industria", la que requerirá de los más variados artilugios para reactivar el capitalismo. En palabras de Bürdek: "Los diseñadores creyeron que su tarea era hacer los productos irresistibles, esto es, intentaron proyectar los deseos y esperanzas subliminales del usuario en los objetos para estimular su compra”. (Bürdek, 2007, p. 111)

En esa tarea, el diseñador pasó del aparato cultural al comercial y se convirtió en una celebridad ante los medios de comunicación. Esto último, al punto tal del caso del consagrado Raymond Loewy, quien fuera el primer diseñador en llegar a la tapa de la prestigiosa revista Time, en Octubre de 1949.

Además las industrias tomarán provecho de esta situación haciendo uso del nombre y la firma del diseñador: “(...) de la misma forma en que los críticos e historiadores de la pintura y la escultura lo habían hecho durante siglos”. (Sparke, 2010, p. 190)

Tanto a partir del crack de 1929, como durante las primeras décadas de la segunda posguerra, la clase media consumió un vasto repertorio de productos de fabricación industrial. Pero más que simples productos, lo que adquirió es la fantasía de estabilidad y progreso; con la ilusión de ser parte del sueño americano: siendo él - como individuo-quien decidía qué comprar; más allá de toda invasión visual, perpetuada por los medios de comunicación. Fundamentalmente, en los medios gráficos, como revistas de moda, interiorismo y decoración; como en las publicidades: primero desde la gran pantalla en los cines: verdaderas catedrales del entretenimiento y la evasión cotidianas; y luego en las pantallas de menores dimensiones, de los primeros televisores: donde el capitalismo penetraba triunfante en los hogares norteamericanos.

Para ello, retomando los ideales racionalistas de la Bauhaus y el Movimiento Moderno, truncados por el advenimiento del Nazismo y la consecuente Segunda Guerra Mundial, surgirán en ambos lados del océano Atlántico las corrientes relacionadas con el Buen Diseño: el Good Design norteamericano y la Gute Form alemana. Estas corrientes también llegarán de primera mano a Latinoamérica, por vías directas de influencia a través del protagonismo del Grupo Austral argentino -con su vínculo directo europeo con el arquitecto Le Corbusier y los ideales del Movimiento Moderno; como así también de la mano de Tomás Maldonado y Gui Bonsiepe: ambos actores activos en la Escuela Superior de Diseño Alemana en ULM: en el caso del Buen Diseño. Consolidada especialmente en Argentina con la posterior creación del Centro de Investigaciones sobre Diseño Industrial en 1962; esta última otorgará, a partir de su primer concurso en 1964, los siguientes premios: "Sólido de Plata, Sólido de Cobre, Etiqueta de Buen Diseño" (Rey, 2009, p. 43). Esta etiqueta provenía de la similar utilizada en Estados Unidos -otorgadas en los concursos organizados por el Museum of Modern Art (MoMA) neoyorquino, como así también por 
las otorgadas por el Design Council inglés (Fiell). Todas estas vertientes del Buen Diseño podrían resumirse en los diez mandamientos desarrollados por Herbert Lindinger, a saber: elevada utilidad práctica, seguridad suficiente, larga vida y validez, adecuación ergonómica, independencia técnica y formal, relación con el entorno, no contaminante para el medio ambiente, visualización de su empleo, alto nivel de diseño, estímulo sensorial e intelectual (Bürdek, 2007).

Algunos ejemplos exitosos y paradigmáticos de esta última corriente mundial, podrían simplificarse en las figuras de: Charles y Ray Eames en los Estados Unidos, comercializando sus variados objetos en la firma Herman Miller; Dieter Rams en Alemania, diseñando la mayor parte de los productos en la empresa Braun; Robin y Lucienne Day en Inglaterra; Alvar Aalto que, en sociedad con su esposa Ainio y otros, funda la empresa de ventas y marketing Artek en Finlandia (Fiell, 2005). En Argentina, también son varias las empresas o locales de venta y diseñadores que abrazaran el Buen Diseño. Cabe resaltar la cuádruple labor de Alberto Churba: diseñador, promotor del diseño local, importador de diseño mayormente nórdico, italiano y norteamericano, y fundador del afamado local CH Centro de Arte y Diseño (Churba, 2008).

Si bien el Buen Diseño se contrapone, en muchos aspectos, con el styling, el streamline y su obsolescencia, será un nuevo estilo funcional al estilo de vida americano, como así también para su expansión mundial por vías de la institucionalización a través del aparato cultural y la promoción publicitaria en el aparato comercial.

\section{En síntesis}

Desde fines de la Segunda Guerra Mundial se afirma la producción en masa y la sociedad de consumo. El capitalismo se reactivó mediante una mezcla de fordismo y política económica keynesiana que otorgó a las clases populares salarios acordes a las necesidades de consumo que requería el propio capitalismo.

El diseño y los diseñadores no fueron ajenos a estas demandas del comercio y la industria, y mediante estilos como el streamline o el styling y posteriormente con el Good Design, provocaron la obsolescencia programada de los productos a través de alguna sus tres variantes por desgaste, moda o status socio económico.

En este contexto surge una clase media caracterizada por el consumismo, la apatía y el modo rutinario de vida cuyas características fueron analizadas por la sociología a través de autores como David Riesman en La muchedumbre solitaria (1950), Herbert Marcuse en El Hombre Unidimensional (1964) o Lewis Mumford en La ciudad en la historia (1961) en donde estudia el nuevo estilo de vida que se extendió en los suburbios estadounidenses de la época. Charles Wright Mills no fue ajeno a este ascenso del consumismo y en diversas conferencias criticó el rol que tomaron los diseñadores en esta etapa del capitalismo, como así también el papel de los arquitectos, los paisajistas, los publicistas y los planificadores urbanos que vendieron sus capacidades artísticas al aparato comercial, sin batallar por una política estética que mejore la calidad de vida en las ciudades.

Puede afirmarse que el diseño constituye una ventana que le permite a Mills analizar las nuevas subjetividades surgidas en la época y el papel de los objetos en esa construcción 
subjetiva. Concretamente, se trata de la nueva clase media protagonista del american way of life, caracterizado por el consumismo como estilo de vida, las conductas homogéneas, el carácter social y políticamente apático, la uniformidad en las formas de vivir y habitar el espacio, la recreación rutinaria y atada a las sugerencias de los medios de comunicación masiva, dentro de las cuales el diseño, los diseñadores y los profesionales de la ciudad, no han hecho más que reforzar ese carácter más que batallar para la generación de subjetividades más libres y creativas.

Contra esta enajenación del individuo y esta banalización del producto, Mills propone el regreso a los valores de la artesanía como “(...) común denominador del arte, la ciencia y el conocimiento y también la raíz misma del desarrollo humano (...). Porque el ideal humano más elevado es convertirse en un buen artesano" (Mills, 2008, p. 5). En esta frase retoma las ideas de William Morris quien -en su conferencia impartida en 1883- alerta: “(...) que nada que no cause placer tanto al productor como al usuario debe fabricarse y ese placer de fabricar ha de producir arte en manos del trabajador”. (Morris, 2005, p. 125) Tal como enseña en La imaginación sociológica (1959), examina el diseño y el rol de los profesionales como un emergente entre la biografía e historia, señalando la alienación que generan estas formas de producción estética y de labor profesional. Pero como buen intelectual que fue, no se queda en el análisis de época sino que reclama a los profesionales la producción de modos menos enajenados de relación entre arte y sociedad.

Por ello, puede decirse que los estudios sociológicos permiten reflexionar sobre el rol de la cultura de una época a través del análisis de los objetos producidos. Al revés, los objetos y su estética, en tanto productos culturales de un momento histórico, habilitan el estudio de los elementos estructurales (producción económica, actores intervinientes con mayor o menor poder) que condicionan su emergencia y sus modos particulares de manifestarse en cada época.

Además, si entendemos la cultura en su definición semiótica tal como la caracteriza García Canclini “(...) la cultura abarca el conjunto de procesos sociales de producción, circulación y consumo de la significación de la vida social” (2004, p. 35), queda claro que Mills realizó un gran aporte a la reflexión entre diseño y cultura al resaltar el valor de símbolo (ritos) y de signo (status socioeconómico) que produce el diseño y los diseñadores al elaborar objetos que permiten dinamizar el consumismo y el capitalismo.

Para cerrar cabe decir que si bien en América Latina Charles Wright Mills fue un autor muy apreciado por la izquierda latinoamericana y sus textos fueron de lectura obligatoria en los cursos de metodología y sociología que dictaba Gino Germani a fines de la década de 1950 (Germani, 2004), sus escritos sobre diseño y diseñadores nunca fueron difundidos.

\section{Notas}

1. Los estudios visuales conforman un campo de estudios que surgió durante la década de 1990 a partir del cruce de dos campos de estudio, la historia del arte y los estudios culturales (una manera de analizar los fenómenos sociales). En esta línea el concepto de historia es sustituido por el de cultura y el concepto de arte por el de "lo visual" (Krochmanly y Zarlenga, 2009). 


\section{Referencias Bibliográficas}

Baudrillard, J. (2014). El sistema de los objetos. México, D.F: Siglo veintiuno.

Becker, H. (1974). Photography and Sociology. Studies in the Anthropology of Visual Communications 1. 1974, 4-10.

Bourdieu, P. (1965). Un art moyen. Essai sur les usages sociaux de la photographie. Paris: Les Editions de Minuit.

Bürdek, B. (2007). Historia, teoría y práctica del diseño industrial. Barcelona: Gustavo Gili.

Caro Almela, A. (2007). Jean Baudrillard y la publicidad. Pensar la Publicidad, Vol I, (2), pp. 131-146.

Carosio, A. (2008). El género del consumo en la sociedad de consumo. La ventana, revista de estudios de género, Vol 3 (27). Recuperado de http://www.scielo.org.mx/scielo. php?script=sci_arttext\&pid=S1405-94362008000100006

Churba, A. (2008). Churba: 30 años de diseño. Buenos Aires: Infinito.

Dannoritzer, C. (2010). Comprar, tirar, comprar. [Película cinematográfica]. España. Radio Televisión Española (RTVE).

Dorfles, G. (1977). El diseño industrial y su estética. Barcelona: Labor.

Drucker, P. (1954). The Practice Of Management. EEUU: Harper y Brothers.

Fiell, C. y Fiell, P. (2005). Diseño Escandinavo. Madrid: Taschen. . (2006). Design Hanbook: Concepts, Materials, Styles. Madrid: Taschen.

García Canclini, N. (2004). Diferentes, desiguales y desconectados. Barcelona: GEDISA.

Gay, A. y Samar, L. (2007). El diseño industrial en la historia. Córdoba: Tec.

Germani, A. (2004). Gino Germani. Del antifascismo a la sociología. Buenos Aires: Taurus.

Goffman, E. (1976). Gender Advertisements. Studies in the Anthropology of Visual Communication, vol. 3 (2), pp 23-29.

Heskett, J. (1980). Industrial design. London: Thames and Hudson.

Krochmalny, S. y Zarlenga, M. (2009). Estudios Visuales y Cultura Visual. Un estado de la cuestión. V Jornadas de Jóvenes Investigadores del Instituto Fino Germani-Facultad de Ciencias Sociales, UBA Recuperado de: http://webiigg.sociales.uba.ar/iigg/jovenes_ investigadores/5jornadasjovenes/EJE4/Mesa\%202/Krochmalny\%20y\%20Zarlenga.pdf

Lipovetsky, G. (1990) El imperio de lo Efímero. Barcelona: Anagrama.

Lucie-Smith, E. (1983). A History of Industrial Design. Oxford: Phaidon.

Marcuse, H. (1964). El hombre unidimensional. Madrid: Ariel.

Mills, C. W. (2008). [1958] The man in the middle. The Designer. In J. H. Summers (Ed.), The politics of truth: Selectedwritings of C. Wright Mills. New York: Oxford University Press, pp. 173-183.

Mills, C. W. (1961) [1959]. La imaginación sociológica, México, Fondo de Cultura Económica. Morris, W. (2005). Cómo vivimos y cómo podríamos vivir. La Rioja: Pepitas de calabaza.

Mumford, L. (1961). La ciudad en la historia. Sus orígenes, transformaciones y perspectivas. New York: Harcourt, Brace \& World.

Rey, J. A. (2009). Historia del CIDI: Un impulso de diseño en la industria argentina. Ciudad de Buenos Aires: Red amigos CMD.

Riesman, D., Glazer, N. y Revel, D. (1950). The Lonely Crowd. A Study of the Changing American Character. New Haven: Yale University Press. 
Sparke, P. (2010). Diseño y cultura una introducción. Desde 1900 hasta la actualidad. Barcelona: Gustavo Gili.

Treviño, J. (2014). C. Wriht Mills as Designer: Personal Practice and Two Public Talks. The American Sociologist, Vol 45 (4), 335-360.

Abstract: The article elaborates on two texts written by sociologist C. Wright Mills where he criticizes the position taken by industrial designers since the 1929 crisis and especially since the Second World War. The author complains that the designer have left their role as part of the cultural apparatus to be a member of the commercial apparatus, in providing their knowledge of art and design to big industry. Since the ' 29 crisis of overproduction invigorated capitalism through massive consumption and planned obsolescence of objects for reasons of prestige or fashion. In this task the designer was indispensable to generate new aesthetic that promote change in fashion or by linking objects to socioeconomic status gear.

For that reason Wright Mills invites designers, architects, landscape architects, urban planners, to rethink their social responsibilities and promote policies that contribute to human welfare.

Key words: Design - Aesthetics - Sociological Theory - Mass Consumption - Planned Obsolescence.

Resumo: O artigo aprofunda sobre dois textos elaborados pelo sociólogo Charles Wright Mills onde critica a posição que tomou o design industrial desde a crise do '29 e especialmente desde a Segunda Guerra Mundial. O autor critica aos desenhadores industriais ter deixado seu papel como parte do aparelho cultural para ser membro do aparelho comercial, ao prestar seus conhecimentos sobre arte e design à grande indústria. Desde a crise de sobreprodução do '29 o capitalismo dinamizou-se através do consumo em massa e a obsolescência programada isto é, do desgaste dos objetos por questões de prestígio ou moda. Nessa tarefa o desenhador foi uma engrenagem indispensável ao gerar novas estéticas que promovem a mudança de moda ou ao vincular os objetos ao status socioeconômico. Por esa razón Wright Mills convida a los desenhadores, arquitetos, paisagistas, planejadores urbanos, a voltar a pensar seu lugar social e promover políticas que contribuam ao bem-estar humano.

Palavras chave: Design - Estética - Teoria Sociológica Consumo em massa - Obsolescência Programada. 



\section{Diseño e indumentaria: una mirada histórica sobre la estética de las identidades de género}

Laura Zambrini *

Resumen: Este trabajo tiene como objetivo principal realizar una historia social del campo del diseño de indumentaria desde una perspectiva de género. Con tal fin, se hace referencia al siglo XIX, momento en que se polarizaron con mayor énfasis las formas de vestir de acuerdo a las diferencias anatómicas binarias entre mujeres y varones. Esto es, en el siglo XIX se acentuaron las diferencias en las maneras de vestir femeninas y masculinas como opuestas y excluyentes. Por esta razón, este artículo propone pensar la indumentaria como un objeto sociológico y semiótico que comunica y produce a través del diseño características de la sociedad que atañen a la corporalidad y la regulación de la sexualidad a través de prácticas estéticas.

Palabras claves: Género - Indumentaria - Sociedad - Diseño - Estética.

[Resúmenes en inglés y portugués en la página 128]

${ }^{(*)}$ Doctora en Ciencias Sociales y Socióloga, ambos títulos otorgados por la Universidad de Buenos Aires. Investigadora Asistente CONICET con sede en el Instituto de Arte Americano (IAA-FADU-UBA). Profesora titular de Sociología en la carrera de Diseño de Indumentaria y Textil (FADU-UBA). Dicta seminarios en las carreras de posgrado de Diseño y Sociología y Diseño de Indumentaria Deportiva (FADU-UBA). Co- coordinadora del Grupo de Estudios Sociológicos sobre Moda y Diseño (GESMODI) en la misma universidad. Publicó diversos trabajos en revistas científicas y de divulgación nacional e internacional. Forma parte del Cuerpo Académico del Doctorado en Diseño de la Universidad de Palermo.

\section{Indumentaria y el diseño del género}

En su desarrollo el campo del diseño ha tenido una fuerte impronta masculina (Garone Gravier, 2013), y como tal, el diseño de indumentaria no es la excepción a la regla. La integración de una mirada que privilegie la perspectiva de género en un campo disciplinar permite establecer las herramientas adecuadas para entender de manera crítica, por un lado, la conformación sociocultural de los estereotipos de género; y por otro, las jerarquías históricas entre varones y mujeres, en tanto jerarquías de poder, que han posicionado de manera desventajosa lo femenino en sentido amplio. 
La indumentaria expresa características de la época y de la sociedad en la que está inserta porque forma parte de la cultura material. En esa directriz, merece un análisis que articule la producción de artefactos con las relaciones sociales. Un estudio sociológico sobre el diseño de indumentaria debe preguntarse por los usos sociales de la vestimenta como acto de comunicación de las identidades sociales.

El vestir es un hecho social y, a su vez, un hecho semiótico pautado por normas y códigos culturales que atañen y comprometen la corporalidad. Es decir, la vestimenta puede ser definida como una práctica corporal contextuada (Entwistle, 2002). Esta definición se aleja de la tradición de estudios sobre el cuerpo que lo definen como algo objetivo y concreto, una materia con límites precisos (Martínez Barreiro, 2004). Pero se apoya en otra línea teórica, en la que se propone la noción de "esquema corporal" en referencia a la dimensión subjetiva del cuerpo. Esa dimensión subjetiva posibilita que el cuerpo sea un espacio permeable a sufrir transformaciones, en constante diálogo con el mundo social. Desde este punto de vista, la corporalidad es establecida como un instrumento de expresión de la personalidad y de la relación con los otros. Es decir, que la corporalidad se manifiesta en la percepción que el sujeto tiene de sí mismo, en las relaciones humanas y la socialización (Martínez Barreiro, 2004). El cuerpo, desde esta óptica, es el lugar a través del cual se experimenta en el mundo, a la vez que se llega a ser visto en él (Merleau-Ponty, 1976). En ese sentido, el espacio público hace más evidente esa exposición corporal frente a la mirada de los otros/as; no obstante, el espacio privado pareciera atenuar ilusoriamente dicha exposición. La indumentaria, como ya se dijo, funciona como parte del lenguaje corporal, siempre relativo a un contexto específico que le imprime sentido. La sociología orientada a los estudios del vestir, ha incorporado las categorías fenomenológicas de tiempo y espacio, precisamente para visualizar cómo la experiencia de cuidar y presentar el cuerpo está social, espacial y temporalmente constituida (Entwistle, 2002; Goffman, 2004 y Martínez Barreiro, 2004).

Asimismo, es importante destacar que los espacios sociales están atravesados por la dimensión de género. Es decir, de acuerdo al género femenino o masculino las experiencias de la corporeidad son diferentes. Lo femenino ha sido históricamente enlazado con lo corporal en términos identitarios (mucho más que lo masculino). Para Goffman, la presentación corporal opera como una señal inteligible, relacionada con las condiciones en las que cada individuo se adscribe y pertenece a una clase social, edad, género, etc. en un contexto y espacio determinado (Goffman, 2004). En términos de Bourdieu, la corporalidad debe ser pensada como una producción social en base a los criterios de la distinción social. Para el autor, la constitución corporal (talla, peso, musculatura, gestos, hábitos alimenticios, de higiene, modificaciones corporales, estética, entre otras) está atravesada por las posiciones y las trayectorias sociales (Bourdieu, 1998).

Esto nos conduce a interrogarnos acerca de la relación entre el campo del diseño de indumentaria y la cuestión de género, más precisamente ¿cómo se ha constituido la dimensión genérica de la cultura material en el campo de la indumentaria?

El supuesto que orienta este artículo es que la indumentaria en la cultura occidental ha tenido un papel significativo en torno a la clasificación de género en términos binarios y en la regulación de la sexualidad. Desde este punto de vista, la indumentaria puede ser caracterizada como un complemento del dispositivo de la sexualidad (Foucault, 2003) que se 
consolida a través de la presentación corporal. Para sustentar estas premisas, a continuación se sintetizan algunos rasgos de la historia de la vestimenta en Occidente, destacando que en el siglo XIX se acentuaron las polarizaciones en las formas de vestir de acuerdo a las diferencias de género entre mujeres y varones.

El siglo XIX es el período clave para entender la consolidación de la sexualidad como dispositivo (Foucault, 2003). Esto es, la producción histórica de la sexualidad como tal, caracterizada por lo binario y la heterosexualidad como la normativa dominante. Además, el siglo XIX fue la etapa en que se consolidaron los discursos amparados por la ciencia cuya impronta transformaba en una desviación patológica a todas las prácticas e identidades no heterosexuales. Los discursos de la medicina y la criminología brindaron los argumentos ideológicos que explicaban la relación natural entre sexo, género y heterosexualidad. La cuestión de la desviación de la norma conllevó a la producción de categorías identitarias que clasificaban $y$, a la vez, condenaban a quienes ejercieran acciones que trascendieran dichas normas. Al respecto, la presentación corporal ocupó un lugar preponderante en lo que atañe a la inteligibilidad de las identidades sociales. Por lo tanto, en este trabajo se analiza la huella estética y cultural que ha tenido la indumentaria, por un lado, en torno a la consolidación de la distinción de clase social; y por otro, en la concepción binaria de las identidades de género, especialmente desde el siglo XVIII hasta nuestros días.

\section{Mirada histórica}

Según la historia de la vestimenta, las primeras civilizaciones que se desarrollaron anteriormente al surgimiento de la moda occidental tales como Persia, Egipto, Grecia y/o Caldea tuvieron modos de vestir relativamente estables (Lipovetsky, 1994). Si bien, existieron cambios éstos no fueron significativos para el desarrollo de una moda propiamente dicha porque no existían cambios estéticos periódicos y regulares. No obstante, lo que aquí interesa en relación al tema presentado, es que en estas civilizaciones la diferenciación en los modos de vestir entre varones y mujeres era casi nula. Acorde a esta perspectiva histórica, el comienzo de la moda lo encontramos en Europa en el período que abarcan los años 1350/70, en consonancia con la expansión del humanismo (Riviere, 1977).

Junto con la aparición de la moda, comenzó a marcarse sutilmente la diferenciación entre la vestimenta femenina y masculina. A partir de entonces, y por casi 200 años, la confección de las prendas ha puesto el énfasis en las diferencias corporales para representar y marcar la diferencia de los géneros (Wilson, 1985 y Saulquin, 2010). Esta diferenciación en la vestimenta entre varones y mujeres fue la que marcó el comienzo de la moda en sentido estrictamente moderno (Lipovetsky, 1994).

En general, la vestimenta se estudió a partir de las diferentes funciones que desempeñó según la época histórica. Sin embargo, estudiarla desde una perspectiva crítica, implica asumir que la misma no es sólo un fenómeno descriptivo de una sociedad. Es decir, cada etapa histórica tiene como correlato determinados patrones estéticos que expresan una cosmovisión, tal como sucede con los usos sociales de la indumentaria (Laver, 1989). A modo esquemático se suele ordenar la historia del vestir en tres etapas: la aristocrática, la burguesa y la consumista (Riviere, 1977). 
En la etapa aristocrática (que abarca desde la Edad Media hasta la Revolución Industrial), predominaron en Europa las elites que controlaban formalmente el privilegio del vestir. Mediante el dictado de las leyes suntuarias se prohibía el uso de determinadas ropas, telas y colores a todos aquellos que no fuesen cortesanos, nobles y/o miembros del clero. Las leyes suntuarias funcionaron como un conjunto de disposiciones legales cuyos objetivos, entre otros, era la regulación de la diferencia social a partir de los usos de indumentaria y del lujo (Riviere, 1977). De este modo, se impedía formalmente que los individuos no pertenecientes a la aristocracia, pudieran emular una mejor pertenencia social mediante la vestimenta. Por ejemplo, estas leyes dictaminaban qué tipo de ropa y colores podían ser utilizados de acuerdo a la jerarquía social, permitiendo por lo tanto, identificar y separar visualmente los rangos y las actividades sociales (Riviere, 1977).

Este sistema del vestir respondía a sociedades cuyas estructuras internas se caracterizaban por la fijeza y estratificación de los roles sociales. Por ende, la indumentaria refería y reflejaba a simple vista las identidades de los sujetos de acuerdo a sus actividades y posicionamientos en la escala social. Esto es, existían prendas que comunicaban la función social en consonancia con la actividad desempeñada. Eran sociedades estratificadas a partir de estamentos rígidos que imposibilitaban el traspaso de un estrato hacia otro.

Las posesiones de las tierras y títulos de nobleza -heredados mediante lazos sanguíneosfuncionaban como los principales atributos para gozar un lugar social acomodado (Riviere, 1977; Laver, 1989, Lipovetsky, 1994). No obstante, el ascenso de la alta burguesía mercantil como grupo social dominante posibilitó que esas características se fueran modificando paulatinamente (Entwistle, 2002; Martínez Barreiro, 1998 y 2004).

La indumentaria en el siglo XVIII estuvo influenciada por los estilos barroco, rococó y neoclásico. Luego, los trajes comenzaron a confeccionarse con menor recarga dando paso a los diseños más simples. El acceso por parte de la burguesía al dinero (pero no al linaje), fue determinante en la disputa por el prestigio social y los privilegios en el vestir (Riviere, 1977). El advenimiento del capitalismo hizo que las leyes suntuarias perdieran sentido dando paso a la lógica de la distinción social (Bourdieu, 1998).

Progresivamente, la emergente sociedad de clases impuso un sistema del vestir que lograba expresar los potenciales cambios internos en la estructura social y las nuevas identidades colectivas. Fue en esta etapa cuando surgió la moda tal como la conocemos hoy día, es decir, con innovaciones permanentes de estilos estéticos y cambios relativos en las jerarquías sociales. Este proceso estuvo acompañado por fuertes transformaciones en el sistema productivo y tecnológico. El trabajo industrial y fabril era el principal organizador de la vida social. El crecimiento de las ciudades y la consecuente concentración de las poblaciones en las urbes, la necesidad de ampliación de los mercados dónde vender lo producido, el intercambio de materias primas entre las colonias, especialmente en el rubro textil, fueron los que impulsaron el desarrollo de la industria de la moda (Riviere, 1977). Por ello, desde una perspectiva sociológica, se suele afirmar que el cambio social y la moda se unieron de manera muy significativa.

En este momento histórico (siglo XVIII) nacieron los recambios de las ropas por temporadas (otoño, invierno, primavera, verano). En épocas anteriores, a excepción de los estratos acomodados, las personas solían tener uno o dos trajes durante toda su vida. La moda burguesa rompió con estos hábitos e introdujo el gusto por el cambio constante en 
el vestir. Los ciclos de la moda se adaptaron a los ritmos industriales, y se encontraron con sociedades que absorbieron positivamente la democratización del vestir y el consumo. La creación de la máquina de coser, como herramienta superadora de los telares, habilitó una rápida confección seriada de prendas de baja calidad y bajo precio/costo dirigida a la distribución masiva en las grandes tiendas/almacenes. De este modo, se consolidó un sistema de la moda bipartito, es decir, compuesto por dos elementos: la alta costura y la confección seriada (Saulquin, 1990).

La moda se democratizó hacia todas las capas sociales debido a la consolidación de la burguesía como grupo dominante y su protagonismo como clase social en la revolución industrial. Esto convirtió a la moda en una incesante fuente de consumo masivo (Lipovetsky, 1994). Las clases populares pudieron tener mayor deseo y acceso al consumo de la moda. No obstante, los privilegios del vestir persistieron en manos de una elite perteneciente a la alta burguesía en los diseños de la alta costura. Es por ello que Riviere sostiene que, en un principio pareció ser efectiva la democratización de la vestimenta, pero más tarde lo fue sólo a nivel parcial porque la elite burguesa conservó el privilegio del vestir y del dinero, al igual que la aristocracia lo hizo en épocas anteriores amparada en las leyes suntuarias (Riviere, 1977). En los talleres textiles las mujeres costureras trabajaban extensas jornadas laborales en condiciones precarias, sin embargo, a nivel simbólico y material dicho trabajo no sólo quedaba invisibilizado, sino que era capitalizado por la figura del estilista o diseñador, tal como sucedió con el creador de la alta costura Charles Worth en Francia.

En ese marco, la moda fue catalogada por la incipiente sociología clásica del siglo XIX como un fenómeno contradictorio porque evidenciaba la lucha presente en la estratificación social. Por un lado, se destacaba la presencia de una elite portadora de los bienes de distinción y, por otro, una inmensa mayoría que intentaba adoptar y/o imitar dichos símbolos distintivos. Las luchas de aspiraciones se cristalizaban cuando la elite trataba de alejarse lo más posible de la masa creando nuevos símbolos de distinción social (Martínez Barreiro, 1998). Autores tales como Simmel y Spencer, postularon que la moda estaba atravesada por el fenómeno de la imitación social porque las clases más pudientes económicamente eran las que intentaban separarse a partir de las apariencias (mediante la ropa, especialmente) de las clases más bajas y populares (Simmel, 1938 y Spencer, 1947). A su vez, estos últimos, mediante la imitación de los sectores más acomodados, pretendían emularlos. Para Simmel, los juegos de las imitaciones y/o distinciones resultaron funcionales para el desarrollo del sistema capitalista porque favorecieron el consumo. Por esta razón, el autor argumentó que la moda tuvo la función social simultánea de unir y diferenciar a una sociedad que se encontraba dividida en clases sociales. La moda cohesionaba a los distintos grupos mediante la estimulación al consumo homogéneo, sin embargo los diferenciaba entre sí por el acceso (o no) al dinero.

Veblen destacó que la indumentaria funcionó como un símbolo de ocio porque llevar una apariencia elegante brindaba información acerca del lugar que el sujeto ocupaba en la estructura productiva. El autor mediante su "teoría de la clase ociosa" (Veblen, 1974) subrayó que un individuo, al invertir su dinero en el consumo de la moda/vestimenta, mostraba a los demás -en una primera instancia- su supuesta capacidad adquisitiva mediante un "derroche ostensible". Tal como se ha dicho, Lipovetsky describe que en la denominada etapa burguesa de la moda (Riviere, 1977 y Lipovetsky, 1994) se conformó un sistema del 
vestir bipartito (Saulquin, 1990) cuya función era básicamente manifestar y salvaguardar la distinción social (Bourdieu, 1998).

Los autores citados a la hora de caracterizar el sistema de la moda han hecho hincapié fundamentalmente en la dimensión de clase y distinción social, dejando de lado las cuestiones de género. Sin embargo, este trabajo sostiene que el sistema de la moda, además de pensarse a partir de la división de clases sociales, también debe tenerse en cuenta la dimensión de género que ha sido desdibujada (Zambrini, 2010).

\section{¿El diseño del género o el género del diseño?}

En este apartado se continúa el recorrido por la historia social de la indumentaria pero desde una perspectiva de género más específica. Se ha destacado que a partir del siglo XVIII la moda como sistema se consolidaba en Europa en la etapa burguesa. Este sistema de la moda también funcionó en el siglo XIX, y llegó a su apogeo a mediados del siglo XX con la cultura de masas. El consumismo masivo como tal, marcó uno de los principales rasgos de la sociedad burguesa (Morin, 1962).

Las pautas del vestir eran tendientes a la homogeneización estética como expresión de sociedades cuyas identidades colectivas eran relativamente estables. Se enmarcaban en la conformación de estados nacionales fuertes y el trabajo industrial/ fabril. Para pensar esta etapa, Foucault señaló que los dispositivos disciplinarios fueron constitutivos de la organización social capitalista (Foucault, 1989 y 2003).

En las sociedades disciplinarias (surgidas en el siglo XVIII y XIX, y con su esplendor en el siglo $\mathrm{XX}$ ) los sujetos eran regulados mediante dispositivos de encierro que funcionaban como instituciones ordenadoras de lo social.

Con la metáfora del panóptico, el autor sugirió que los mecanismos de dominación (asociados a la idea de vigilancia) caracterizaron a la sociedad moderna por lo carcelario. Esto supone operaciones de poder que moldean los cuerpos a través de discursos que se constituyen en regímenes de verdad, y establecen las condiciones de posibilidad del pensar y del hablar, e inclusive engendran las resistencias al mismo. Si bien, Foucault nunca relacionó sus teorías con la moda y las prácticas del vestir, ciertas perspectivas de análisis sostienen que sus planteos sobre el disciplinamiento de los cuerpos también se pueden enlazar con la historia social de la moda (Turner, 1989 y Enwistle, 2002). Por ejemplo, en el siglo XIX, la figura del corsé femenino ilustra una manera de disciplina y opresión sobre los cuerpos de las mujeres porque el uso de esa prenda era asociada a cuestiones morales. Hay que destacar que la perspectiva de género tampoco está presente en la obra de Foucault, no obstante, algunos trabajos feministas posteriores, como los realizados por J. Butler, han incorporado la noción del poder esbozada por el autor para explicar al cuerpo generizado, a partir del esquema binario identitario de lo femenino y lo masculino (Butler, 1997 y 2001).

El encuentro entre el feminismo y la corriente de pensamiento post estructuralista, posibilitó que el género pueda ser caracterizado como una tecnología (De Lauretis, 1989; Foucault, 1990 y Butler, 2001). Esto es, como un proceso complejo propio de la modernidad que está orientado a la producción de sujetos "normales" a partir de la regulación de la praxis, estableciendo a la heterosexualidad como la norma principal de referencia, 
y a la homosexualidad como una desviación (Becker, 1971). Como ya fuera planteado al comienzo del trabajo, a mediados del siglo XIX la vestimenta incrementó la división entre los imaginarios femeninos y masculinos.

La cultura occidental, en ese momento histórico, recreó a través de la moda dos patrones en las formas de vestir binarios y excluyentes entre sí: uno para los varones y otro para las mujeres. Ambos patrones simbolizaban valores opuestos, por un lado, la ropa femenina debía connotar el sentido de la seducción de las mujeres; y por otro lado, dicho sentido tenía que estar ausente en los atuendos masculinos (Dutrá é Mello, 2007).

Los trajes femeninos se tornaron más complejos en cuanto a sus confecciones, las telas y los bordados utilizados. En cambio, los trajes masculinos sufrieron el proceso inverso debido a la simplificación de los modelos que los despojó de casi todo elemento decorativo. Esta etapa es denominada "la gran renuncia del siglo XIX", porque los valores del puritanismo de la etapa victoriana y los cambios producidos por la revolución industrial transformaron los comportamientos sociales y las relaciones cotidianas.

Desde el Renacimiento hasta mediados del siglo XIX, la historia de la moda evidencia que, tanto varones como mujeres, solían vestirse de manera extravagante y lúdica. Nobles y burgueses compitieron por el poder a través de las ropas hasta alrededor de la década de 1830, luego los valores puritanos y los cambios causados por la Revolución Industrial reestructuraron los comportamientos sociales, y también las lógicas del vestir (Dutrá é Mello, 2007). Esto es, el traje masculino tendía a la uniformidad y a la sobriedad -a diferencia de los usados en la etapa aristocrática en las cortes- y les permitía a los varones connotar rectitud, elegancia, formalismo, limpieza y distinción social, en oposición a la estética de la belleza y la sensualidad que eran considerados atributos exclusivos de lo femenino.

La figura de la gran renuncia ha posibilitado reflexionar sobre las implicancias simbólicas y estéticas que tuvieron, por un lado la separación genérica de los modos de vestir entre varones y mujeres; y por otro, que los elementos decorativos dejaran de formar parte de los atuendos masculinos, y quedaran remitidos a lo femenino. El vestuario de los varones perdió su función ornamental, y privilegió la uniformidad como un atributo de decoro y de buen vestir, pero especialmente como un atributo de masculinidad. De este modo, la indumentaria masculina además de marcar la distinción social y el acceso a los ámbitos de poder ligados a lo público y lo económico; a su vez, pasó a simbolizar la naturalización de la identidad de género en oposición a la identidad femenina, y viceversa. Existe una consonancia entre la ideología de la época en torno a la heterosexualidad obligatoria y las normativas en torno a las maneras de presentación corporal que tendieron a consolidar lo binario también en la vestimenta.

En relación a los modos de vestir de las mujeres, el traje femenino en el siglo XIX, tendió a marcar la silueta y las formas de los cuerpos. La combinación de la ropa con los accesorios recreó un estereotipo de una estética femenina, asociada al adorno y lo decorativo como rasgo identitario que a primera vista, se diferenciaba de lo masculino. No obstante, dentro del universo femenino también hubo subdivisiones pues la doble moral victoriana hacia diferencias entre las mujeres que se podían visualizar a través del vestir. Por otra parte, las modas femeninas estaban basadas en el uso de prendas que dificultaban los movimientos corporales de las mujeres. Esto consolidaba el imaginario moderno que las alejó de la fase productiva. Se reificaba la supuesta división entre una esfera pública (asociada a lo 
masculino) de la otra esfera privada, ligada a lo doméstico como ámbito de la femineidad (Veblen, 1974).

Estos estilos de vestimenta también remarcaron la distinción de clase social porque no todas las mujeres quedaron por fuera del mundo del trabajo. Sin embargo, cuanto más se impidiera el movimiento corporal de las mujeres a través de la ropa, más se marcaba una posición social acomodada porque se diferenciaba de los modos de vestir de aquellas que sí trabajaban, por ejemplo en las fábricas textiles (Martínez Barreiro, 1998).

En este aspecto, puede verse que la división sutil de los géneros por medio de la presentación corporal, también impregnó la puja entre las clases sociales pero con características distintas. El consumo de moda quedó asociado a las clases que tenían una mejor pertenencia social debido a la posesión de dinero para comprar, y la consecuente posibilidad de plasmar en las prácticas del vestir la distinción social (Simmel, 1938 y Veblen, 1974). La redistribución del ingreso, el capital y las condiciones laborales eran discusiones que concernían al orden público y que, por lo tanto, dejaban de lado a las mujeres.

Las primeras reivindicaciones feministas nacieron peleando contra esta configuración del orden patriarcal, y denunciando la construcción de la representación de la mujer en tanto objeto erótico ideal y de deseo en pos de la mirada masculina (de Beauvoir, 1949; Bourdieu, 2000). Es decir, el feminismo buscó ampliar la noción de ciudadanía para negociar los espacios de poder que relegaban a las mujeres hacia la domesticidad de manera pasiva, y las reducía a frágiles objetos decorativos, o bien, reproductivos.

\section{Palabras finales}

A modo de cierre parcial, este trabajo se propuso reflexionar acerca de las prácticas del vestir como hechos sociales que condicionan las formas de percibir y experimentar el mundo a través de la corporalidad. En este sentido, la vestimenta, en tanto objeto de diseño, es portadora de históricas cargas de género.

Ello le otorga al campo del diseño de indumentaria una fuerte impronta femenina que se manifiesta en ciertos prejuicios a partir de la feminización de los actores que intervienen en dicho campo. A la vez, como hemos visto a lo largo del trabajo, este campo es heredero de un acervo cultural que privilegia lo masculino en desmedro de lo femenino.

En cierto modo, eso ha favorecido la legitimación social de otros campos del diseño tales como el industrial o el gráfico, ambos campos de predominio masculino. No obstante, según Garone Gravier (2013), tanto el diseño industrial como el diseño gráfico, no han reconocido debidamente la labor de las mujeres en la consolidación de dichos campos, situación que no es exclusiva de las disciplinas proyectuales. La necesidad de incluir la perspectiva de género radica en desestabilizar las certezas culturales que han jugado en contra de las mujeres en términos simbólicos y materiales. Y en particular, para desnaturalizar los sesgos sexistas que acontecen en los ámbitos profesionales y académicos del diseño que han ubicado la producción de los objetos como si fueran neutrales, despojados de toda relación histórica y social.

En ese camino, el diseño de indumentaria puede ser una buena herramienta de transformación sociocultural, basándose en novedosas propuestas en torno a las corporalidades 
y los usos sociales de la vestimenta. Esto es, en búsqueda de la ruptura de los estereotipos de género, privilegiando la funcionalidad por sobre todo mandato estético y de consumo.

\section{Referencias bibliográficas}

Becker, H. (1971). Los extraños. Sociología de la desviación. Buenos Aires: Tiempo Contemporáneo.

Bourdieu, P. (1998). La distinción. Madrid: Taurus.

Butler, J. (1997). “Sujetos de sexo / género / deseo”. Feminaria. Año X, Nº19, Junio, Buenos Aires.

Butler, J. (2001). El género en disputa. El feminismo y la subversión de la identidad. Buenos Aires: Paidós.

Braidotti, R. (1999). "Diferencia sexual y nomadismo". Revista Mora 5.

De Beauvoir, S. (1949). El segundo sex. Buenos Aires: Sudamericana.

De Lauretis, T. (1989). Technologies of Gender. Essays on Theory, Film and Fiction. Bloomington: Indiana University Press.

Dutrá é Mello, J. L. (2007). Onde vocé comprou esta roupa tem para homem? : A construcao de masculinidades nos mercados alternativos de moda. Rio de Janeiro: Record.

Entwistle, J. (2002). El cuerpo y la moda. Una visión sociológica. Barcelona: Paidós.

Foucault, M. (1989). Vigilar y Castigar. Buenos Aires: Siglo XXI.

Foucault, M. (1990). Tecnologías del yo. Barcelona: Paidós.

Foucault, M. (2003). Historia de la sexualidad. Vol. I: La voluntad del saber. Buenos Aires: Siglo XXI Editores

Garone Gravier, M. (2013). "Los designios de Eva: El género en la identidad del diseño latinoamericano" en Revista_180 Nro. 24, Facultad de Arquitectura, Arte y Diseño, Universidad Diego Portales. Ver: /www.revista180.udp.cl/ediciones/24/eva_24.htm

Goffman, I. (2004). La presentación de la persona en la vida cotidiana. Madrid: Amorrortu. Laver, J. (1989). Breve historia del traje y la moda. Madrid: Cátedra.

Lipovetsky, G. (1994). El imperio de lo efimero. Barcelona: Anagrama.

Martínez Barreiro, A. (1998). La moda en las sociedades modernas. Madrid: Tecnos.

Martínez Barreiro, A. (2004). La construcción social del cuerpo en las sociedades contemporáneas. Papers 73 .

Merleau-Ponty, M. (1976). Fenomenología de la percepción. Madrid: Península.

Morin, E. (1962). El espiritu del tiempo. Madrid: Taurus.

Riviere, M. (1977). Moda: ¿comunicación o incomunicación? Barcelona: Gili.

Saulquin, S. (1990). La moda en la Argentina. Buenos Aires: Emecé.

Saulquin, S. (2010). La muerte de la moda Buenos Aires: Paidós.

Simmel, G. (1938). Cultura femenina y otros ensayos Buenos Aires: Espasa Calpe.

Spencer, H. (1947). Principios de Sociología. Buenos Aires: Revista de Occidente.

Turner, B. (1989). El cuerpo y la sociedad: exploraciones en teoría social México: FCE.

Veblen, T. (1974). Teoría de la clase ociosa. México: FCE.

Wilson E. (1985). Adorned in dreams: Fashion and modernity Londres: Virago. 
Zambrini, L. (2010). "Modos de vestir e identidades de género: reflexiones sobre las marcas culturales sobre el cuerpo" en Revista de Estudios de Género Nomadías Nro. 1 Santiago de Chile: Universidad Nacional de Chile.

\begin{abstract}
The main objective is to make a social history of desing of dressing from a gender perspective. There will be a tour of the nineteenth century because there were polarized forms of dress according to sex and anatomical differences between women and men. In the nineteenth century were accentuated the differences in the ways male and female dress as opposite and mutually exclusive. Therefore, this article proposes to think dressing as a complement of big importance in the consolidation of the heterosexual matrix and the design of rules of gender binary and aesthetics.
\end{abstract}

Key words: Gender - Dressing - Society - Desing - Aesthetics.

Resumo: O objetivo principal deste trabalho é fazer uma história social do campo do design da roupa de uma perspectiva de gênero. Para esse propósito, é feita referência ao século XIX, altura em que polarizou com maior ênfase os modos de vestir de acordo com as diferenças anatômicas binárias entre mulheres e homens. Isto é, no o século XIX acentuou as diferenças no vestido masculino e feminino em oposição e excluindo. Por este motivo, este artigo propõe pensar em roupas como um objeto sociológico e semiótico que se comunica e produz através do design características da sociedade que dizem respeito à corporalidade e à regulação da sexualidade através de práticas estéticas.

Palavras chave: Gênero - Vestuário - Sociedade - Design - Estética. 
Fecha de recepción: marzo 2017 Fecha de aceptación: octubre 2017 Versión final: marzo 2019

\section{Marcas de shopping o de diseñador. Los procesos de adscripción en la moda}

Bárbara Guershman *

Resumen: El objetivo de este artículo consiste en comprender de qué forma se desarrollan los procesos sociales de adscripción, en función de cómo un grupo de productores de indumentaria (prendas de vestir, calzado y accesorios) intervienen en eventos y exhibiciones bianuales de moda. El presente escrito está basado en el trabajo de campo etnográfico realizado para mi tesis de doctorado. Fue en el curso de dicho trabajo que advertí la relevancia de dos categorías: marca y diseñador. Estas categorías remiten a la forma en la cual esos productores se identifican públicamente. Constituye una identificación relativa al volumen de prendas que conforman su producción por temporada, los espacios sociales donde comercializan la indumentaria, así como las imputaciones morales respecto a la presencia de la copia. Esta copia expresa la mayor o menor influencia de tendencias internacionales de moda en un producto propio o la carencia de características propias del autor-diseñador.

Quienes son reconocidos como diseñadores, pretenden estar alejados de estas tendencias. Por otra parte, sus colecciones incluyen menos prendas que las marcas, las cuales se caracterizan por venderse en shopping, centros comerciales ubicados en CABA y conurbano. Pero esta distinción se pone en cuestión en varios contextos llevando a que las categorías de marca y diseñador se articulen entre sí. Es una articulación que describiré en el escrito.

Palabras clave: diseño - moda - indumentaria - producción - comercialización.

[Resúmenes en inglés y portugués en las páginas 142-143]

${ }^{(*)}$ Magister en Antropología (IDEAS- UNSAM). Docente de grado en la Universidad Nacional Arturo Jaureche, en la Universidad de Belgrano y en la Universidad del Este. Estudia desde hace más de 5 años desde una perspectiva antropológica el diseño de indumentaria y ha integrado proyectos de investigación UBACYT y PIP en ese marco. Asimismo ha sido expositora de numerosos congresos nacionales e internacionales cuanto ha publicado en esas mismas esferas.

\section{Introducción}

El objetivo del presente artículo consiste en comprender cómo se desarrollan los procesos de adscripción en el campo de la moda de CABA (Ciudad Autónoma de Buenos Aires). 
Para ello, comenzaré por hacer referencia a mi trabajo de campo etnográfico puesto que, a partir del mismo, es como llegué a ahondar en los múltiples usos de lo que considero las dos principales categorías "nativas" dentro del campo: diseñador y marca.

Este trabajo se inició en el 2005 y se extendió a la actualidad, con una eventual interrupción para completar la tesis de maestría, defendida en el 2009. A lo largo de estos años, he venido -de forma recurrente- realizando entrevistas no dirigidas a productores de ropa. Asimismo, a organizadores de eventos, gerentes de marketing, maquilladores, peinadores, estilistas y productores ${ }^{2}$. Asimismo, he realizado observaciones (con mayor o menor grado de participación ${ }^{3}$ ) en sesiones de fotos, desfiles y celebraciones de apertura de locales de venta al público. Finalmente, la investigación incluyó la recopilación de artículos de revistas, suplementos y folletos dedicados a la temática del diseño y la moda.

Fue en el curso de esta investigación que reparé en una distinción realizada por los entrevistados respecto a los productores: ser una marca comercial o ser diseñador. El lector habrá advertido que a ambas categorías les agregué el verbo ser. Esta inclusión, lejos de ser casual, obedece a la propia forma en la cual los productores se presentan. En vez de plantear que fundaron tal empresa o emprendimiento, emplean expresamente ese verbo vinculado con la marca, que denota su identidad.

La identidad es un asunto que, según Claude Levi-Strauss (1981), puede ser tratado en dos niveles: el correspondiente al sujeto individual y al nivel grupal referido a la identidad étnica. En este sentido, el autor señala que el nombre propio remite tanto a la inscripción social del sujeto en un grupo como la identidad de la persona misma. ¿Es posible discriminar realmente ambas dimensiones? Si asigno mi nombre a una empresa o fundación ¿se trata del sujeto que asigna tal denominación o estamos hablando de un nivel grupal que da cuenta del vínculo entre el productor y el conjunto de personas que tratan con él? Durante años, presumí que la distinción antes mencionada era excluyente, lo cual significaba que se era una cosa o la otra. Pero esta sospecha fue posteriormente descartada en el curso de las entrevistas y observaciones. Mas aún, se complejizó. Para algunos productores, la distinción era excluyente y lo sigue siendo. Otros la ampliaron al señalar que se consideraban marcas y diseñadores a la vez. Algunos se identificaron como marcas de diseñador en contraposición a las marcas de shopping. Entendí así que la identidad de quienes producen ropa resultaba más vasta que una mera oposición de categorías, por lo cual debía atender a las formas en las cuales las mismas se articulaban.

Este artículo trata, como indiqué previamente, acerca de los procesos de adscripción en el cual se ven implicados los productores de ropa y quienes participan junto a ellos en la moda: modelistas, dueños de talleres de confección, productores de desfiles, maquilladores, gerentes de marketing y jefes de producto. Me interesa dar cuenta de los contextos en los cuales se desarrollan estos procesos que están ligados a la identidad, en el sentido que lo plantea Fredrik Barth (1976). Para este antropólogo noruego, la identidad étnica remite al término de límite referido, a su vez, a las categorías de adscripción que son empleadas por los actores mismos y al mismo tiempo, regulan la interacción entre estos.

Lo que este autor propone es que el límite social es lo que define al grupo y no el contenido. Esto es: lo que nos separa de otros nos define. Lo que propongo desarrollar en este trabajo, basándome en la perspectiva de Barth acerca de la identidad como un proceso dinámico, son las formas en las cuales se constituye la auto y hétero adscripción, en el caso 
de los productores de ropa y cuáles son las situaciones en las que estas formas se ponen en cuestión.

\section{Las colecciones y sus escalas}

En primer lugar, el ser reconocido por otros -a la vez que reconocerse a uno mismo-como un diseñador o una marca depende del número de prendas que un productor confecciona por temporada. Este conjunto de prendas se llama colección. Lo que varía entre los productores es precisamente la cantidad de prendas que confeccionan en correspondencia con las dimensiones de su negocio. Es decir, cuantos locales o "puntos de venta" detentan. A estas dimensiones se refirió Paulina, quien es la jefa de producto ${ }^{4}$ de la sección dedicada a la elaboración de prendas de denim. Dicha sección forma parte de "Antea" que es una cadena de indumentaria de origen chileno. Creada en 1989, esta empresa posee tiendas departamentales situadas en diferentes ciudades de América Latina. En estas tiendas se comercializa indumentaria masculina, femenina e infantil. Además, muebles, equipos de electrónica y electrodomésticos.

Antes de trabajar en Antea, una marca grande como la describió Paulina, ella trabajó en el mismo puesto del "departamento de producto" de otra empresa fundada por una diseñadora quien empleó su nombre y apellido para registrarla como "María Rodríguez"6. Actualmente, la marca cuenta con doce locales. Seis de ellos están situados en centros comerciales.

Con Paulina nos encontramos en el patio de comida de un centro comercial situado junto a la autopista, el límite entre el barrio porteño de Núñez y la localidad de Martínez, al norte del conurbano bonaerense. El patio de comidas, que incluye varias cadenas de restaurantes, está emplazado en el tercer piso. A la hora en la cual nos encontramos, en su horario de almuerzo, costaba hallar mesas libres donde acomodarnos.

Una de mis primeras preguntas fue cómo ella distinguía el trabajo realizado en una marca de diseñador de otra que no lo era. Meditó unos instantes y comenzó por indicar que la marca de diseñador tiene una identidad, un sello definido y propio, más allá de que en ésta se tengan en consideración las tendencias de moda mundiales. Pero el seguimiento de las tendencias tiene sus matices. Todos los que producen ropa las tienen en consideración -subrayó Paulina- lo que varía es cuan significativa es esta influencia sobre ellos.

La copia constituye una cuestión ambigua en el mundo de la moda, señala Alec Balacescu (2005) debido a que constituye una práctica condenada moralmente y reproducida por los diseñadores cuando producen ropa. Para este antropólogo, es difícil determinar que constituye una copia, más allá de las legislaciones que salvaguardan los derechos del autor de una obra ante posibles falsificaciones. Si bien es inevitable que la copia se haga presente en el proceso de creación de una prenda, la dificultad radica en donde identificarla. Desde la perspectiva de los diseñadores iraníes con quienes él realizó su investigación, los habitantes de Teherán -capital de Irán- consideran que todo es pasible de ser imitado: la ropa así como estilos de vestir parisinos, difundidos por canales de moda. ¿La imitación constituye una copia? Es ahí donde radica la ambigüedad. En el curso de mi trabajo de campo, esa ambigüedad se expresaba cuando los diseñadores argumentaban que ellos, lejos de 
copiarse, se inspiraban en tendencias provenientes de los centros de moda. No eran estas el objeto de la condena moral, sino como la forma en la cual eran apropiadas.

Diez años antes de mi almuerzo con Paulina, otra diseñadora llamada Vanina se refirió a tal apropiación con un ejemplo. Comentó que, en la temporada del 2005, estaban de moda las cadenas doradas. Aunque las consideraba de "mal gusto", no las podía obviar en la colección porque se las pedían las clientas. En consecuencia, adecuaba este adorno al estilo de su propia marca. Junto con otros diseñadores, fundó una marca dedicada a la producción de accesorios para mujeres, fabricados con elementos de descarte: mangueras, neumáticos de auto y cuentas de goma. Si bien ella no podía obviar lo que estaba de moda, lo adaptaba a su forma de hacer ropa. Otros diseñadores planteaban que la reproducción constituía una copia cuando una modelista replicaba en un vestido la moldería correspondiente a otro vestido. Teniendo en cuenta la ambigüedad señalada por Balacescu, el desafío es establecer cuáles son los límites (si es que se pueden establecer límites nítidos) entre la adaptación, la adecuación, la inspiración y la mera reproducción de las bases de moldería de un vestido o elaborar una cadena dorada con plásticos de descarte.

Sumado a la cuestión controvertida de la copia, que será retomada posteriormente, otra dimensión de la diferencia entre una marca comercial y una marca de diseñador es el volumen de ropa que se produce y cómo se produce. En este sentido, Paulina caracterizó la ropa de María Rodríguez como: "más exclusiva y manual, más cara y menos industrializada”. En María Rodríguez, ella trabajaba con un equipo de diseñadores que realizaban prendas de forma artesanal, por lo cual el producto ${ }^{7}$ les resultaba más caro de confeccionar. La complejidad en la hechura de las prendas implicaba dificultades al procurar hallar talleres textiles dispuestos a realizarlas. Su confección requería más tiempo de trabajo, lo cual incrementaba su precio. Como si mantuviera un diálogo imaginario con el dueño de un taller y fuera éste el que replicara, Paulina concluyó: "Sí te podemos hacer 100, 500 ya es muy difícil para nosotros. ¿Entendés?”

A los volúmenes hizo alusión Marianela, ex jefa de producto que trabajó en una empresa dedicada a la fabricación de calzado que tiene varias sucursales en CABA y otras ciudades al interior de Argentina. La entrevisté en su departamento, situado en el barrio de Palermo. Mas precisamente, en el área llamada "Palermo Soho" ${ }^{8}$. En este departamento, de dos ambientes, realizaba ferias durante los fines de semana donde exhibía vestimenta de diseñadores quienes se la entregaban en consignación para que la vendiera. Al hacerlo, Marianela aplicaba un porcentaje al precio de la vestimenta, colgada en percheros metálicos. Si no se vendía, la devolvía. En las marcas donde ella trabajó antes de iniciar las ferias -señaló- se hacían cantidades grandes. A modo de ejemplo, contrastó las 1000 unidades de una colección de una marca a partir de cada modelo, respecto a los 10 o los 20 modelos realizados por los diseñadores.

Si la copia constituye una cuestión ambigua como señalé previamente, también lo es la cantidad porque no se trata solo de números sino de diferentes escalas en la confección y comercialización en un contexto que es la moda. Para la socióloga Johanne Entwistle (2002), estas escalas corresponden a diferentes "sistemas de provisión". Dentro de la moda, que ella define como una industria, distingue dos sistemas o sectores: la ropa exclusiva hecha a medida, propia de la alta costura y la confección masiva. Esta distinción no solo fue señalada por esta autora sino que está presente en la teoría social sobre la moda. A esta 
distinción se refirió Pierre Bourdieu (1990), para quien esta última constituye un campo de producción cultural, en relación a dos sub campos: la producción restringida limitada a los productores y la gran producción orientada a un público ampliado?

Respecto a ambos sistemas o sub campos ¿es posible establecer un límite nítido entre ambos? ¿Cómo determinar cuándo un vestido está orientado al gran público cuando antes se dirigía a uno reducido? Expresado de otra forma, mi inquietud radica en saber de qué forma se desarrolla el proceso por el cual un vestido ingresa al sistema de la confección masiva. En lo que respecta al trabajo de campo realizado, advertí que las escalas de producción entre quienes se identificaban como diseñadores eran más o menos próximas a las indicadas por Marianela. No obstante, cada productor tenía su propia escala que variaba de acuerdo a las circunstancias de su propia forma de producir.

Este es el caso de Anabela. Ella es una egresada de la carrera de DIT (Diseño de Indumentaria y Textil) que se dicta en la Universidad de Buenos Aires ${ }^{10}$. Tras graduarse, obtuvo un premio otorgado por una institución del gobierno municipal de CABA para llevar a cabo su desfile en el BAF Week. Esta institución está dedicada a la promoción de los emprendimientos de diseño. El dinero del premio le permite al ganador solventar los gastos de la confección de ropa desfiladas por las modelos. El programa abona además los honorarios de las modelos, maquilladores, peinadores y musicalizadores.

A fines del 2015, Anabela inauguró su primer local de venta al público en el barrio de Retiro. Previamente, comercializaba su ropa en su showroom ${ }^{11}$. Este consistía en un departamento al cual se accedía tras atravesar un extenso pasillo. A su local recién estrenado me dirigí un caluroso día de enero del 2016. Su socio no estaba presente en la entrevista, un productor de zapatos con quien se había asociado para concretar la apertura.

Tras felicitar a Anabela por tal apertura, le pregunté cómo se presentaba a sí misma. Debido al hecho de que la marca llevaba su nombre, se consideraba una marca de diseño. Aún no creía ser una marca comercial ya que carecía de la estructura de producción y comercialización que tienen las marcas. Específicamente, debería inaugurar más puntos de venta. A fin de incorporar saberes relativos al manejo de un negocio, asistió a unos talleres dictados por la institución que le facilitó el capital para realizar el desfile. La asistencia, obligatoria para seguir participando en el programa, le permitió incorporar esas herramientas administrativas: cálculo de costos, precios y elaboración de balances contables. Tras atender ella misma a un cliente, quise saber cómo producía la ropa. Lo que ella denominaba básicos ${ }^{12}$ se los encargaba a un taller de confección que describió como: las cosas que hago en cantidad. Algunos pantalones eran realizados por unas modistas. Ella se ocupaba personalmente de la moldería de las prendas de sastrería como vestidos ${ }^{13}$. Por temporada, hacía aproximadamente 70 modelos. De cada modelo, elaboraba más de 20 unidades por prenda.

Son dos las cuestiones que fueron tratadas en este primer apartado. En primer lugar, como es valuada moralmente la copia. En segundo lugar, la reproducción. Ambas fueron tratadas como problemas en la sociología y la antropología del arte. Interesado en el tema de la reproducción, Walter Benjamin (1989) destaca como fenómeno de la modernidad lo que llama la "reproductictibilidad técnica" de la obra de arte que, al imponer lo masivo, anula la singularidad y garantía de autenticidad: el aquí y ahora del original. En esta imposición, se produce una progresiva lejanía con el aval de origen de la pieza, una fotografía o 
escultura. Arjun Appadurai e Igor Kopytoff (1990) son dos antropólogos para quienes, sin embargo, la anulación de la singularidad no llega a ser total en la producción masiva de mercancías, entre las cuales se incluyen las obras de arte. La masividad, que torna homogéneo el valor de las cosas, convive en la época actual con la tendencia contraria que es la singularización. Esta implica la distinción cultural de ciertas mercancías dentro de esferas de intercambio: bienes de lujo, reliquias u objetos de colección.

En esta parte del trabajo, describí diferentes escalas en la multiplicación de los modelos de las prendas que los productores confeccionan: Anabela o las marcas en las cuales trabajaron Marianela y Paulina. La confección no está desligada, sin embargo, de la comercialización y el consumo. Con esto quiero decir que las escalas relativas a las reproducciones precisan ser descritas en vinculación con los espacios urbanos donde los modelos se exhiben y venden. Al análisis de estos espacios me dedicaré en el siguiente apartado: la localización del local de venta al público en uno o varios centros comerciales o la vía pública.

\section{Los espacios de comercialización}

Comenzaré esta parte del trabajo señalando que los productores, reconocidos como diseñadores, suelen detentar un único local como Anabela. ¿Que sucede si ella -u otro diseñador-inaugurara un local en un shopping? Aun así podría ser reconocida socialmente como diseñadora por ella misma y otros productores. O bien, estos podrían imputarle el hecho de haberse convertido en una marca de shopping.

Ambas posibilidades se hacen patentes en un video editado por un canal de moda. Es la filmación de una animada fiesta de apertura realizada en el 2011, en un local dentro del "Shopping Alcorta". En el curso de la fiesta, un periodista conversa con Gustavo, el dueño de la marca de zapatos para mujeres a quien el primero presenta como empresario y a su socia como diseñadora textil. Gustavo considera que el shopping es distinto a los otros: es un shopping de diseño que valora a los diseñadores. En consecuencia, no tuvo reparos en concretar la apertura. Son reparos que, según el periodista, sí expresaron otros diseñadores. Respecto a Anabela, ella se identificaba a si misma como una diseñadora que, en virtud de haber recibido asesoramiento en finanzas y marketing, se estaba convirtiendo en una marca chica. No obstante, añadió instantes después, eso no la convertía automáticamente en una marca de shopping. Le pregunté a que se refería:

Anabela: "no me gustaría ser comercial, así como estar llena de locales pero sí creo que está bueno que una marca de diseño, que un diseñador pueda convertirse en una marca. Por ejemplo, FAMA es un caso que está buenísimo porque él [menciona el nombre del diseñador creador de la firma ${ }^{14}$ ] no deja de ser un diseñador y es una marca comercial. Yo no me considero una marca porque me considero en pleno crecimiento. Para ser una marca me falta a nivel comercial, desde tener más puntos de venta hasta ampliar el nivel de producción"

Más allá de las disyuntivas de los productores respecto a cómo les gustaría o pretenden ser reconocidos, es preciso señalar que la apertura de un local en un shopping no constituye 
un paso inmediato sino que depende de muchos factores. En primer lugar y teniendo en cuenta lo indicado por Anabela, ella debería incrementar el volumen de producción de ropa para detentar más locales. A estos factores aludió Armando, el jefe de producto de "Castaneda". Esta es una empresa que gestiona la administración y funcionamiento de tres marcas de indumentaria femenina en Argentina.

A la oficina de Armando, situada a tres kilómetros de la bajada de una autopista en el conurbano bonaerense, me dirigí un día de octubre del año 2015. Era una oficina situada en un centro de distribución donde se concentraban empresas de varios rubros. La oficina formaba parte de un hangar cuyas paredes y techo eran de chapa, al cual se accedía subiendo una escalera de hierro.

$\mathrm{Al}$ presentarme con la secretaria, me hizo pasar a un salón acondicionado con sillones. Armando me saludó y ofreció un café. Tras conversar media hora, quise saber de qué forma decidían, dentro de la gerencia de la empresa, en cuales shopping abrir locales. Tras servirse un café, respondió que eso obedecía a varias variables. En líneas generales, si una marca aspiraba a captar un volumen significativo de compradores, el shopping lo garantizaba. Esta era una garantía de volumen que no se producía en la calle. Esta categoría designa los locales abiertos en la vía pública, que no aseguraban ese volumen de clientes debido a los ocasionales días de lluvia o las situaciones de inseguridad. Las mismas no se producían dentro del centro comercial que contrata empresas de vigilancia privada. Tras unos minutos de conversación, agregó que algunos establecimientos otorgan a las marcas la masividad (la posibilidad de apuntar a varios mercados de consumidores) mientras que otros garantizan el prestigio y la exclusividad.

Dentro de cada shopping, a su vez, la valuación de los pisos es variable. En algunos centros comerciales, hallar locales en los pisos más elevados resulta más costoso para las marcas al ser los más codiciados y onerosos en el alquiler mensual. En otros centros, los precios de los alquileres se incrementan contrariamente en la planta baja. Esta ubicación era la más requerida por las marcas.

La clasificación de las marcas como de shopping no constituye un proceso simple porque el ingreso a estos lugares tampoco lo es. A dicho proceso aludió Mely -la ex gerente de Marketing de Castaneda- quien aludió a una "lista de espera" para que las marcas ingresaran. Una vez producida la entrada, era preciso tener en consideración los metros ocupados por cada local y la facturación mensual exigida a cada una de ellas. De no lograr esa facturación, se les sugería a los dueños desplazarse a pisos menos codiciados o bien desalojar el local definitivamente. En suma, ser una marca de shopping supone ingresar a un mundo que ya esta clasificado según los establecimientos. Pero la clasificación opera al interior de estos, según los espacios recorridos por los visitantes.

Como señala García Canclini (2004) respecto a Mary Douglas y Baron Isherwood (1990), el consumo sirve para pensar el mundo. Mas precisamente, el consumo establece y fija socialmente significados en relación a las mercancías. Respecto a los centros comerciales, es un mundo en el cual la distribución del espacio es pensada al igual que son pensados sus ocupantes y visitantes. En relación a los consumidores, los trabajos sociológicos acerca del espacio y el consumo destacaron invariablemente la figura del "flaneur", termino francés acuñado por Walter Benjamin para referirse al paseo en Paris del siglo XIX como un paseo y experiencia. 
Este término fue retomado, en esos trabajos, para describir como son transitados los espacios de consumo urbanos contemporáneos. Sobretodo, la recorrida por los shopping o malls, como se denomina en Estados Unidos a los paseos de compras. En el caso de Mike Featherstone (1998) el autor se refiere a los centros de compras y sitios turísticos como espacios de sociabilidad en los cuales se adquieren bienes ligados simbólicamente a estilos de vida y status.

Cuando un paseante pasea por un shopping, se detiene en los puestos ubicados en los pasillos ante los locales o se dirige al patio de comidas o las salas de cine. El o ella está recorriendo un espacio que ha sido ya clasificado según las lógicas y las luchas simbólicas entre las marcas que los ocupan. A estas luchas alude Bourdieu (2010) cuando señala que, en una sociedad jerárquica, no hay espacio que no esté jerarquizado. Y estos rangos se expresa, en el espacio físico, en la concentración de determinados bienes y servicios situados en lugares centrales o mas valorizados. El flaneur recorre, en consecuencia, pasajes que fueron jerarquizados. Y esta jerarquización depende de cada shopping porque en cada uno rigen valorizaciones dispares. Debido al hecho de que el shopping es un mundo clasificado socialmente, quienes lo transitan y alquilan locales vendiendo bienes se categorizan a sí mismos y a otros no solo respecto a lo que venden sino a cuánto venden. En definitiva, no basta señalar que Anabela o una marca de zapatos son marcas de diseñador o de shopping sino remitir estas categorías de adscripción a su particular ubicación en un establecimiento. Y dentro del mismo, a determinado piso y a quienes lo recorren.

\section{La copia de la tendencia}

En tercer lugar, el reconocimiento (auto y hétero) de un productor como diseñador se produce a partir de las llamadas tendencias, referidas en el primer apartado de este trabajo. Mas bien, la réplica de las mismas que los nativos llaman copia. La tendencia designa una forma de conocimiento acerca de la indumentaria que prevalecerá en una determinada temporada. Por ejemplo, si transitamos la temporada otoño-invierno del 2017, la tendencia correspondería a la temporada primavera-verano del mismo año o, incluso, a las temporadas del 2018.

La tendencia es una forma de conocimiento que circula globalmente entre diferentes ciudades en torno a los llamados "centros" o "capitales" de moda: París, Londres, Nueva York y Milán (Sally Weller, 2007; Fred Davis, 1992). En estas urbes se difunden las nuevas modas, se origina la novedad a partir de la exhibición de las colecciones en desfiles a los cuales concurren compradores. Esta novedad genera lo que Davis llama el "proceso" o "ciclo" de la moda que incluye etapas como la difusión de un novedad, saturación, declinación y obsolescencia. Es un proceso en el cual intervienen los compradores indicados al igual que editores, periodistas y publicistas. En suma, un conjunto de personas conscientes de los vaivenes de la moda.

Esta forma de conocimiento económico, compleja y multidimensional, como la describe Weller, se expresa en los catálogos y las revistas en sus formatos gráficos y digitales. Se difunde globalmente como flujos en función de una cierta configuración témporo-espacial dentro de la industria textil. Constituye una configuración anclada en el poder y la posi- 
ción diferencial de quienes participan en tal industria. Consiste en un poder y posición relativa en torno a la gravitación de lugares y localizaciones "centrales y claves" -los centros señalados- en las cuales participa una comunidad implicada en tal conocimiento.

Los estudios acerca de como se difunden los estilos de vestir son fundantes en la sociología de la moda y el consumo. En los primeros modelos "clásicos" (uno de los mas reconocidos fue el propuesto por Georg Simmel llamado "trickle down"15) se proponía que las modas se difundían de arriba hacia abajo: las clases altas imponían estilos luego imitados por las clases bajas. Estos modelos fueron reemplazados por planteos mas complejos, no necesariamente basados en la división de clases. De acuerdo a la socióloga Diana Crane (1999) quien elabora un recuento de estos estudios, la difusión no solo tiene que ver con la diferencia entre clases sociales sino con cuestiones generacionales: grupos de edad o determinadas minorías que imponen estilos en centros urbanos. Por otra parte, la difusión global de los estilos de vestir se caracteriza actualmente por un situación de descentralización. Esto significa que París y Londres ya no son las únicas capitales de moda aunque no perdieron su relevancia. Debido a tal descentralización, la autora destaca el desarrollo de empresas dedicadas a la predicción de lo que prevalecerá en futuras temporadas en base a la información recolectada por sus empleados, al recorrer circuitos comerciales de diferentes ciudades.

Quienes trabajan en empresas situadas en Argentina, viajan ellos mismos -o parte de su personal- a las ciudades reconocidas como "centros" donde asisten a desfiles o ferias en las cuales toman fotografías en celulares y computadoras portátiles. Este viaje se llama de producto o de tendencia $y$, como resultado del mismo, se desarrollan las colecciones de temporada. Al contactarla, Paulina me advirtió precisamente que debíamos concretar el encuentro después de su propio viaje que planeaba hacer en enero. En otras ocasiones, debí aplazar otras entrevistas porque el diseñador o jefe de producto con quien me iba a reunir también debía hacerlo. O lo realizaba el jefe y el diseñador desarrollaba la colección en función de las prendas o catálogos traídos. Algunos diseñadores recordaban esa planificación con cierto fastidio por haber tenido que copiar ropa hecha por otro. Un viaje del cual pretendían distanciarse al iniciar su propia marca.

¿Cómo un diseñador instituye socialmente esa distancia cuando afirma que está en camino de ser una marca? ¿Cómo los actores que participan en la moda distinguen, en un desfile, las colecciones de los diseñadores o marcas? Estos fueron los interrogantes que invariablemente planteé en mis entrevistas a periodistas como es el caso de Lina quien, asimismo, es editora de varias revistas y suplementos de moda. Con ella me reuní en una confitería situada en la intersección de las avenidas Santa Fe y Coronel Díaz. Lina concurría asiduamente a los desfiles realizados en el BAF Week (la "semana de la moda" de Buenos Aires) en los cuales se acomodaba en la primera fila reservada a los miembros acreditados de prensa. En su condición de espectadora, quise saber cómo reconocía las diferencias entre los productores. Replicó que las colecciones de los diseñadores eran innovadoras y no seriadas. Las colecciones de las marcas de shopping, por su parte, se limitaban a mostrar tendencia mas allá de que contrataran diseñadores en su plantel de empleados. Respecto a esta última, quise saber si se refería a la tendencia mundial o la que prevalece en un centro urbano como CABA. Ella replico que, de hecho, las tendencias que llegaban a CABA provenían de otros centros para añadir que no la consideraba como un centro. 
¿De que modo una ciudad es ponderada como centro? Stella Bruzzi y Pamela Church Gibson (2013) plantean que París lo es (junto con otras tres ciudades como Londres, Nueva York y Milan) en función de una formación histórica urbana que, en función de una difusión sostenida de la prensa, le otorgó una superioridad simbólica, económica y política respecto a otras metrópolis. Solo dando cuenta de esta formación en función de la cual se distinguen ciertas ciudades es posible comprender la relevancia de la tendencia en mi investigación. Si bien se ha ampliado el número de ciudades influyentes, no todas constituyen centros de moda reconocidos. En este sentido, Frederic Godart (2014) señala que las ciudades obtienen reconocimiento interviniendo en una arena donde compiten globalmente, excluyendo a algunas al no participar en el flujo de información sobre estilos de vestir.

Para los diseñadores que trabajan en marcas, la referencia a los centros de moda y la información difundida entre éstos se hace presente en su cotidianidad cuando deben realizar el viaje indicado. ¿Qué sucede cuándo los diseñadores crean su propia marca? Respecto a esta cuestión, planteada previamente, Vanina señaló que debía incluir en sus colecciones las cadenas doradas aunque le disgustaran. Por su parte, Vivi es una diseñadora egresada de la carrera de DIT que, en todas las entrevistas, negaba sistemáticamente ser una marca comercial aunque le resultaba difícil evitarlo. A ella la conocí en el 2005, tras asistir a uno de sus desfiles. Mientras me mostraba un perchero en su showroom situado en el barrio de Belgrano, señaló que esa dificultad radicaba en no hacer prendas de moda y, no obstante, procurar que estas se vendieran.

Recordé entonces la primera vez que acudí al primer local de Vivi, situado en el barrio de Palermo, a unas cuadras de Palermo Soho. En ese entonces, equiparó la moda con la tendencia, con un mandato que viene de afuera. En el curso del mismo año, me reuní con Lila cuyo local se situaba en la misma área dentro del barrio. Al igual que Vivi, Lila nació en la primera mitad de la década de 1970. Lila conocía a Vivi y pondero sus prendas de sastrería. La describió como una diseñadora que: hace lo que se le canta. No pude menos que reírme con este comentario y Lila se rió conmigo, aclaro que a Vivi no le interesaba si vendía o no lo que producía. Ella misma se describió como un diseñador "intermedio":

Lisa "soy intermedio porque soy un diseñador que se está metiendo en la cadena comercial sin dejar de ser diseño de autor, no quiero perder eso. Vivi es una diseñadora pura y neta. O sea, no se va a mover de ahí. Son diseñadores que hacen lo que se les canta".

Barbara: "Vivi tiene su propio local, ¿puede realmente hacer lo que se le canta, lo que quiere?"

Lisa "vos podés hacer lo que se te canta cuando tenés un local y no tenés venta mayorista. Si vos tenés solo un local, hacés lo que se te canta. Lo vendés o no vendés. Vas generando como tu clientela que es chiquitita y es un negocio chico. Cuando te metiste en la cadena comercial, es como que empezás a ampliarlo".

Al compararse con Vivi, Lila describió su negocio, la escala en la cual producía y comercializaba la ropa. Al inicio de la conversación, celebró la apertura de su local en el "Alcorta Shopping”. Unos meses antes, había inaugurado otro en el "Shopping Unicenter". Respecto 
a ambas aperturas, reafirmó ser una marca de diseño dentro de un lugar comercial como el shopping donde se copia todo. Estaba por preguntarle si ella también copiaba al haberse incorporado a ese lugar. Negó con la cabeza y añadió que, si bien tenía en cuenta la tendencia mundial, sus colecciones eran únicas en el sentido de que diseñaba absolutamente todo. $\mathrm{Al}$ inicio de este escrito me referí a la adscripción, en función de la perspectiva de Fredrik Barth (1979) acerca de los límites. Estos se mantienen a pesar de las situaciones de contacto social producidas entre individuos de diferentes culturas. Los marcadores de identificación persisten a pesar de la interacción interétnica. Si bien este trabajo no trata precisamente acerca de las identidades étnicas, la idea de límite resulta operativa para reflexionar como el mismo productor que celebra la inclusión dentro de un shopping, reafirma el límite que lo distancia de las marcas que comercializan en este espacio. Esta reafirmación solo se comprende si recordamos que la copia es objetada moralmente en la moda. Esto es, que se reivindique la condición de diseñador y que lo hagan quienes están en potencial situación de "contaminación" por el hecho de estar ligados a la tendencia.

La noción de contaminación fue señalada por la antropóloga Mary Douglas (1973) en "Pureza y Peligro" en relación a situaciones que subvierten un orden en la vida social y trastocan determinados valores morales. En estas situaciones es donde se reivindican categorías sociales, con el objetivo de imponer orden en un entorno como la producción y comercialización de ropa.

De acuerdo a John Heskett (2002), el diseño puede ser considerado algo decorativo y banal si atendemos a la forma en la cual es tratado en revistas de decoración, signado además por los ciclos de la moda. Lejos de ser banal y según lo desarrollado en este trabajo, el diseño y la moda implican procesos de identificación y estos se complejizan cuando las personas que producen ropa se desplazan en el espacio social, viajan a otras ciudades, realiza fiestas de apertura de locales en shopping o incrementan el volumen de ropa confeccionada.

\section{Comentarios conclusivos}

Podría decir que la adscripción es un proceso complejo, que depende de diversas dimensiones algunas de las cuales fueron exploradas en este artículo, pero eso sería puntualizar lo obvio. Mas bien prefiero señalar cuáles fueron las cuestiones tratadas en este artículo, a partir de mi investigación. Asimismo, cómo estas cuestiones se articulan con temáticas que ya fueron tratadas en la sociología y antropología.

En primer término, la diferencia entre diseñador y marca se funda en los volúmenes de producción producidos. Pero esto da lugar a entender las condiciones en las cuales se produce como, por ejemplo, la admisión de ciertos pedidos en talleres de confección. Estos talleres aceptan o rechazan los pedidos en función de las escalas que sus dueños manejan. En este sentido, uno de los comentarios recurrentes, en el curso del trabajo de campo, que algunos talleristas privilegiaban los pedidos de marcas grandes en desmedro de los encargos de diseñadores. Nos encontramos aquí con la temática de la reproductictibilidad técnica tratada por Walter Benjamin. Más precisamente, de qué forma la producción de ropa comprende varias escalas de reproductictibilidad. Entre lo masivo y lo singular como extremos, encontramos diferentes variantes al momento de elaborar ropa. 
En segundo término, ser una marca de diseñador en vías de ser reconocida como marca de shopping como formas de adscripción constituye una temática que remite a la sociología del consumo y las compras que se desarrollan en espacios urbanos. Los trabajos inscriptos en tal sociología centraron su atención en los circuitos de consumo que incluyen el shopping, el mall o los locales comerciales en la vía pública. En estos trabajos se analizó como se desarrollaba la compra como experiencia. En base a cuáles criterios compraban las personas. Mi planteo en este trabajo es que la compra debe ser analizada teniendo en cuenta su inscripción en espacios ya jerarquizados y clasificados según las marcas que los ocupan. Mas aun, los análisis del consumo en espacios como los shopping, Palermo Soho u otras áreas dentro de CABA deben ser llevados a cabo teniendo en cuenta como las marcas se han instituido como una de las principales formas de clasificación contemporáneas. No se compra solo un vestido negro sino un vestido que forma parte de una marca, la cual está asociada a varios significados sociales.

La tercera temática tratada fue la difusión de las modas y las moralidades asociadas a tal difusión. Esto nos remite al tema de la copia y la reproducción mencionadas previamente. Sobretodo, en que consiste la autenticidad como valor y quienes ensalzan tal valor en la moda donde, señaló Balacescu, la copia es realizada cotidianamente aunque no siempre sea posible admitir tal hecho. Pero también la copia tiene que ver con la configuración geográfica de los centros de moda en las cuales se inscribe Buenos Aires. La categoría nativa "tendencia" implica, en sí, el análisis de cómo se divulga la moda como flujos de información y quienes intervienen en esta divulgación.

\section{Notas}

1. Se entiende por categorías "nativas", según Guber (2001), expresiones que adquieren una significación distintiva en la sociedad estudiada por el etnógrafo. Es decir, adquieren una significación en el contexto de la lógica local.

2. Se denomina "productor" o "estilista" a la persona encargada de organizar un desfile que implica la selección de las modelos, la musicalización y la coreografía. Asimismo, el conjunto de prendas que se van a exhibir. Puntualmente en esta última elección se realiza en conjunto con el diseñador.

3. La participación, en articulación con la observación, implica formar parte de las actividades que realizan los miembros de la población en estudio. El énfasis recae en la experiencia vivida por el investigador. En mi caso, la participación implicó asistir a desfiles como espectadora. No solo asistí a la exhibición de la ropa sino que me involucré en el momento posterior a la misma. Esto es, el momento en el cual los asistentes se sacan fotos y conversan entre si.

4. Se denomina jefe de producto a la persona que, en una empresa, está a cargo del departamento de producto en el cual se coordinan instancias de la confección como la realización de moldes, muestras, la costura, adición de avíos, planchado y distribución de las prendas en locales. Asimismo, la persona a cargo asiste a los locales para llevar el recuento de las prendas que se venden. 
5. Los nombres de los informantes y las empresas donde trabajaron y trabajan actualmente fueron cambiados para preservar su privacidad.

6. Es una característica a destacar es que una gran parte de los productores a quienes entrevisté decidieron registrar su empresa utilizando su propio nombre y apellido.

7. Con esta categoría, designan algo a ser vendido en el mercado que tanto puede ser una prenda de vestir como cualquier otra mercancía. En este sentido, los diseñadores que realizan prendas para otros llaman a lo que entregan como producto terminado.

8. Con esta denominación, se alude a un área del barrio de Palermo en las cuales predominan las mueblerías, galerías de arte, tiendas de ropa y artículos de decoración. Esta circunscrita por las avenidas Santa Fe, Córdoba, Scalabrini Ortiz y Juan B. Justo. En ocasiones, también se la llama "Palermo Viejo". La razón del título "Soho" se explica por una referencia a un distrito homónimo dentro de las ciudades de Londres y Nueva York.

9. Para Bourdieu, la moda constituye un campo de producción cultural en el cual se libra una lucha entre los agentes por la apropiación del capital legítimo que es la magia de la firma del productor sobre una pieza: una obra de arte o un vestido. Pero la magia, señala el autor, no la produce el artista o modisto sino los agentes que le otorgan un poder creador. 10. La carrera, cuyo plan de estudios se creó en 1988, se dicta en la Facultad de Arquitectura, Diseño y Urbanismo que forma parte de la Universidad señalada donde se dictan seis carreras. Actualmente, se dicta la misma carrera en otras instituciones educativas universitarias y terciarias.

11. El showroom refiere a un espacio (departamento, casa o estudio) en el cual el productor recibe a sus clientes. Significa espacio de exhibición en inglés y se distingue del local de venta al público. También se llama showroom a los puestos que se instalan en el hall central del pabellón donde se desarrolla el BAF Week (Buenos Aires Fashion Week). El mismo es un evento que se lleva a cabo bienalmente en el Predio Ferial de Palermo desde el año 2000. 12. Se denomina básico a prendas como un pantalón de jean o una remera. Se las llama así en el sentido de ser vestibles. Otra categoría nativa referida a la combinación. Esto es, el hecho de ser una prenda fácilmente combinable con otras prendas.

13. La moldería constituye la instancia de producción de moldes. Las mismas consisten en planchas de papel que corresponden a las piezas de una prenda. Actualmente, los moldes también se realizan mediante programas de computación.

14. Se trata de un diseñador egresado de la carrera de DIT. UBA, nacido en 1970. En el 2002, inició su emprendimiento en el cual, como característica saliente de su producción, realiza combinaciones de diferentes tejidos.

15. En este modelo, que podría ser traducido aproximadamente como "goteo hacia abajo", Georg Simmel plantea que las modas son modas de clase, son el producto de la separación clasista. Esto significa que las modas de la clase superior se diferencian de las clases inferiores y son abandonadas por aquellas cuando estas se las apropian.

\section{Lista de referencias bibliográficas}

Appadurai, A. (1990). La vida social de las cosas. Perspectiva cultural de las mercancías. Arjun Appadurai, eds. Editorial Grijalbo. México. 
Balacescu, A. (2005). "After Authors. Sign(ify)ing Fashion from Paris to Tehran”. En: Journal of Material Culture. Vol. 10(3): 289-310.

Barth, F. (1976). Los grupos étnicos y sus fronteras. Fondo de Cultura Económica. México.

Benjamin, W. (1989). "La obra de arte en la época de su reproductibildad técnica". En: Discursos Interrumpidos I. Editorial Taurus. Buenos Aires

Bourdieu, P. (1990). “El campo literario. Prerrequisitos críticos y principios de método". En: Revista Criterios. La Habana, no 25-28, enero 1989-diciembre 1990, pp. 20-42

Bourdieu, P. (2010). "Efectos de lugar". En: La miseria del mundo. Fondo de Cultura Económica. Buenos Aires.

Bruzzi, S. y Church Gibson, P. (2013). Fashion Cultures Revisited: Theories, Explorations and Analysis.

Guber, R. (2001). La etnografia. Método, campo y reflexividad. Grupo Editorial Norma. Bogotá.

Guber, R. (2004). El salvaje metropolitano: reconstrucción del conocimiento social en el trabajo de campo. Paidos. Buenos Aires.

Godart, F. (2014). “The power structure of Fashion Industry: Fashion Capitals, Globalization and creativity”. En: International Journal of Fashion Studies. Volume 1. Number 1.

Davis, F. (1992). Fashion, Culture and Identity. The University of Chicago Press.

Douglas, M. y Isherwood, B. (1990). El mundo de los bienes. Hacia una antropología del consumo. Editorial Grijalbo. México.

Douglas, M. (1973). Pureza y Peligro. Un análisis de los conceptos de contaminación y tabú. Siglo XXI. México.

Entwistle, J. (2002). El cuerpo y la moda. Una vision sociológica. Editorial Paidos. Barcelona.

Featherstone, M. (1998). “The Flâneur, the City and Virtual Public Life”. En: Urban Studies, Vol. 35, Nros. 5-6, 909-925

García Canclini, N. (1999). "El consumo sirve para pensar". En Constructores de Otredad. Boivin, M., Rosato, A. y Arribas, V. Editorial Antropofagia. Buenos Aires.

Heskett, J. (2002). El diseño en la vida cotidiana. Editoria Gustavo Gili. Barcelona.

Levi-Strauss, C. (1981). La identidad. Ediciones Petrel. Barcelona.

Simmel, G. (1999). "La moda”. En: Cultura femenina y otros ensayos. Alba editorial. Barcelona. Weller, S. (2007). Fashion as viscous knowledge: fashion's role in shaping trans-national garment production. Journal of Economic Geography, 7(1):39-66.

\begin{abstract}
The goal of this article is to understand the development of social process identification. These dynamics are based on the way a group of clothing producers (garment, footwear and accessories) participate in biannual fashion events and exhibitions. This works builds upon my ethnographic fieldwork for my Phd thesis. Precisely during my fieldwork I noticed the relevance of two categories: brand and designer. These categories related to the way producers publicly identify among themselves. This identification is associated to the number of garments that conforms the season collection. Besides it is related to the social spaces where producers commercialize the garments and also to the moral imputations about the often-called copia. The copia presumably expresses more or less, the influence of global fashion trends.
\end{abstract}


The producers recognized as designers would like to remain isolated for these trends. On the other hand, their collections include less garment that the brand's collections. In addition, brands typically sell in shopping, mall located throughout CABA and the metropolitan area. But this distinction is questioned in several contexts, leading to the articulation between the categories of brand and designer. The present article describes this articulation.

Key words: design - fashion - clothing - production - commercialization.

Resumo: O objetivo do presente artigo consiste em compreender de que forma se desenvolvem os processos sociais de atribuição na moda, em função de como um grupo de produtores de indumentária (vestimenta, calçado e acessório) intervém em eventos e exibições bianuais de moda. Este artigo baseia-se no meu trabalho de campo etnográfico realizado para a tese de doutorado. Foi durante a elaboração desse trabalho que entendi a relevância de duas categorias: marca e design. Estas categorias se remetem na forma em que os produtores se identificam publicamente entre eles. Constitui em uma identificação relativa ao volume de roupa incluída na produção de temporada, aos espaços sociais onde comercializam a roupa, assim como as imputações morais em relaçãoà presença da chamada cópia. Esta cópia expressa a maior ou menor influência das tendências internacionais da moda num produto próprio ou a carência das características próprias do designer. Aqueles que são reconhecidos como designers, pretendem estar distanciados dessas tendências. Por outro lado, suas coleções incluem menos prendas que as marcas, as quais se caracterizam por vender-se em shoppings, centros comerciais localizados em CABA e na área metropolitana. Más esta distinção esta sendo questionada em vários contextos, levando a que as categorias de marca e design se articulem entre si. Neste artigo descrevo a mencionada articulação.

Palavras chave: design - moda - indumentária - produção - comercialização. 



\section{Publicaciones del Centro de Estudios en Diseño y Comunicación}

El Centro de Estudios en Diseño y Comunicación de la Facultad de Diseño y Comunicación de la Universidad de Palermo desarrolla una amplia política editorial que incluye las siguientes publicaciones académicas de carácter periódico:

\section{- Cuadernos del Centro de Estudios en Diseño y Comunicación [Ensayos]}

Es una publicación periódica que reúne papers, ensayos y estudios sobre tendencias, problemáticas profesionales, tecnologías y enfoques epistemológicos en los campos del Diseño y la Comunicación.

Se publican de dos a cuatro números anuales con una tirada de 500 ejemplares que se distribuyen en forma gratuita.

Esta línea se edita desde el año 2000 en forma ininterrumpida, recibiendo colaboraciones remuneradas, dentro de las distintas temáticas.

La publicación tiene el número ISSN 1668.0227 de inscripción en el CAICYT-CONICET y tiene un Comité de Arbitraje.

- Creación y Producción en Diseño y Comunicación [Trabajos de estudiantes y egresados] Es una línea de publicación periódica del Centro de Producción de la Facultad. Su objetivo es reunir los trabajos significativos de estudiantes y egresados de las diferentes carreras. Las producciones (teórico, visual, proyectual, experimental y otros) se originan partiendo de recopilaciones bibliográficas, catálogos, guías, entre otros soportes.

La política editorial refleja los estándares de calidad del desarrollo de la currícula, evidenciando la diversidad de abordajes temáticos y metodológicos realizados por estudiantes y egresados, con la dirección y supervisión de los docentes de la Facultad.

Los trabajos son seleccionados por el claustro académico y evaluados para su publicación por el Comité de Arbitraje de la Serie.

Esta línea se edita desde el año 2004 en forma ininterrumpida, recibiendo colaboraciones para su publicación. El número de inscripción en el CAICYT-CONICET es el ISSN 16685229 y tiene Comité de Arbitraje.

\section{- Escritos en la Facultad}

Es una publicación periódica que reúne documentación institucional (guías, reglamentos, propuestas), producciones significativas de estudiantes (trabajos prácticos, resúmenes de trabajos finales de grado, concursos) y producciones pedagógicas de profesores (guías de trabajo, recopilaciones, propuestas académicas).

Se publican de cuatro a ocho números anuales con una tirada variable de 100 a 500 ejemplares de acuerdo a su utilización. 
Esta serie se edita desde el año 2005 en forma ininterrumpida, su distribución es gratuita y recibe colaboraciones para su publicación. La misma tiene el número ISSN 1669-2306 de inscripción en el CAICYT-CONICET.

\section{- Reflexión Académica en Diseño y Comunicación}

Las Jornadas de Reflexión Académica son organizadas por la Facultad de Diseño y Comunicación desde el año 1993 y configuran el plan académico de la Facultad colaborando con su proyecto educativo a futuro. Estos encuentros se destinan al análisis, intercambio de experiencias y actualización de propuestas académicas y pedagógicas en torno a las disciplinas del diseño y la comunicación. Todos los docentes de la Facultad participan a través de sus ponencias, las cuales son editadas en el libro Reflexión Académica en Diseño y Comunicación, una publicación académica centrada en cuestiones de enseñanza-aprendizaje en los campos del diseño y las comunicaciones. La publicación (ISSN 1668-1673) se edita anualmente desde el 2000 con una tirada de 1000 ejemplares que se distribuyen en forma gratuita.

\section{- Actas de Diseño}

Actas de Diseño es una publicación semestral de la Facultad de Diseño y Comunicación, que reúne ponencias realizadas por académicos y profesionales nacionales y extranjeros. La publicación se organiza cada año en torno a la temática convocante del Encuentro Latinoamericano de Diseño, cuya primera edición fue en Agosto 2006. Cabe destacar que la Facultad ha sido la coordinadora del Foro de Escuelas de Diseño Latinoamericano y la sede inaugural ha sido Buenos Aires en el año 2006.

La publicación tiene el Número ISSN 1850-2032 de inscripción y tiene comité de arbitraje.

A continuación se detallan las ediciones históricas de la serie Cuadernos del Centro de Estudios en Diseño y Comunicación:

\section{Cuadernos del Centro de Estudios de Diseño y Comunicación [ ISSN 1668-0227 ]}

$>$ Cuadernos del Centro de Estudios en Diseño y Comunicación. [Ensayos]: Materialidad difusa. Prácticas de diseño y tendencias. Daniel Wolf: Prólogo de la Universidad de Palermo | Jorge Pokropek y Ana Cravino: Algunas precisiones sobre la borrosa noción de "Materia" para el diseño interior | Leila Lemgruber Queiroz: Desmaterialización e inmaterialidad en el contexto contemporáneo del Diseño | Maximiliano Zito: La sustentabilidad de Internet de las Cosas | Gabriela Nuri Barón: La des-materialización de productos tangibles en una perspectiva de sustentabilidad | Marina Andrea Baima: El proceso de diseño desde la génesis de los materiales | Marinella Ferrara and Valentina Rognoli: Introduction by the School of Design of Politecnico di Milano | Marinella Ferrara and Anna Cecilia Russo: The Italian Design Approach to Materials between tangible and intangible meanings | Linda Worbin: Designing for a start; irreversible dynamic textile patterns | Zurich Manuel Kretzer: Educating smart materials | Murat Bengisu: Biomimetic materials and design | Valentina Rognoli and Camilo Ayala Garcia: Material activism. New hybrid scenarios between design and technology | Giulia Gerosa and Laura Daglio: 
Diffuse materiality in public spaces between expressiveness and performance | Giovanni Maria Conti: Material for knitwear: a new contemporary design scenario | Giulio Ceppi: Slow+Design as sustainable sensoriality: an innovative approch aimed to explore the new relationships among design, innovation and sustainability. (2018). Buenos Aires: Universidad de Palermo, Facultad de Diseño y Comunicación, Centro de Estudios en Diseño y Comunicación. Vol. 70, diciembre. Con Arbitraje.

$>$ Cuadernos del Centro de Estudios en Diseño y Comunicación. [Ensayos]: Presente y futuro del diseño latino. María Verónica Barzola: Prólogo de la Universidad de Palermo | Rita Ribeiro: Prólogo da Universidade do Estado de Minas Gerais. FILOSOFÍA DEL DISEÑO Y CONTEXTO SOCIAL: Jorge Gaitto | María Verónica Barzola | Celso Carnos Scaletsky, Chiara Del Gaudio, Filipe Campelo Xavier da Costa, Gerry Derksen, Guilherme Corrêa Meyer, Juan de la Rosa, Piotr Michura y Stan Ruecker | Anderson Antonio Horta. EL DISEÑO COMO AGENTE DE TRANSFORMACIÓN SOCIAL: María Ledesma | Silvia Sasaoka, Giselle Marques Leite, Mônica Cristina de Moura y Luís Carlos Paschoarelli | Caroline Salvan Pagnan y Artur Caron Mottin | Simone Abreu | Zulma Buendía De Viana | Elisangela Batista. EL DISEÑO COMO FACTOR DE DESARROLLO ECONÓMICO: María del Rosario Bernatene y Guillermo Juan Canale | Liliana Durán Bobadilla y Luis Daniel Mancipe Lopez | Ana Urroz-Osés | Camilo de Lelis Belchior. FORMACIÓN PARA EL DISEÑO SOCIAL: Rita Aparecida da Conceição Ribeiro | Cristian Antoine, Santiago Aránguiz y Carolina Montt | Polyana Ferreira Lira da Cruz y Wellington Gomes de Medeiro | Carlos Henrique Xerfan do Amaral, André Ribeiro de Oliveira y Sandra Maria Nunes Vivone | Ana Beatriz Pereira de Andrade y Henrique Perazzi de Aquino. (2018). Buenos Aires: Universidad de Palermo, Facultad de Diseño y Comunicación, Centro de Estudios en Diseño y Comunicación. Vol. 69, septiembre. Con Arbitraje.

$>$ Cuadernos del Centro de Estudios en Diseño y Comunicación. [Ensayos]: Cine e Historia. Pluralidad de voces y miradas sobre el autoritarismo y el totalitarismo. Zulema Marzorati y Mercedes Pombo: Prólogo | Rodolfo Battagliese: Poder estatal y dominación de género: sus representaciones en La linterna roja (China, 1991) de Zhang Yimou | Lizel Tornay: Representaciones de mujeres en el cine de realizadoras feministas durante los períodos posdictatoriales. España y Argentina | Zulema Marzorati y Mercedes Pombo: El fascismo en la pantalla: Vincere (Italia, Bellochio, 2009) | Victoria Alvarez: Cine, represión y género en la transición democrática. Un análisis de La noche de los lápices | Tzvi Tal: La estética del trauma y el discurso de la memoria: personajes infantiles ante el terror estatal en Infancia clandestina (Ávila, Argentina, 2011) | Moira Cristiá: Frente el autoritarismo,la creación. La experiencia de AIDA y su relectura en el film El Exilio de Gardel (Fernando Solanas, Francia / Argentina, 1985) | Sonia Sasiain: El lugar del Estado en la representación de la vivienda popular: desde la construcción de la opinión pública hacia la censura | Mónica Gruber: Medios y poder: 1984. (2018). Buenos Aires: Universidad de Palermo, Facultad de Diseño y Comunicación, Centro de Estudios en Diseño y Comunicación. Vol. 68, julio. Con Arbitraje.

$>$ Cuadernos del Centro de Estudios en Diseño y Comunicación. [Ensayos]: La dimensión ideológica de la enseñanza del diseño. Cecilia Mazzeo: Prólogo. La dimensión ideológica 
de la enseñanza del diseño | Constanza Necuzzi: Educación, enseñanza y didáctica en la contemporaneidad | Inés Olmedo: La Dirección de Arte en el cine, desafíos disciplinares y pedagógicos | Beatriz Galán: Reconstruyendo el entramado de una sociedad creativa. Estrategias para la formación de diseñadores en contextos de complejidad | Clara Ben Altabef: Intenciones para una didáctica proyectual. Caso: asignatura Proyecto y Forma en la FAU-UNT | Diego Giovanni Bermúdez Aguirre: El estado de posibilidad de la Historia del Diseño | María Ledesma: Luces y sombras en la enseñanza del Diseño. Una reflexión sobre su transformación en saber universitario | Ana Cravino: Enseñar Diseño: La emergencia de la teoría | Mabel Amanda López: Modos de decir y modos de ser: palabra e ideología en el taller de diseño | Ana María Romano: La construcción de la cosmovisión durante la enseñanza. (2018). Buenos Aires: Universidad de Palermo, Facultad de Diseño y Comunicación, Centro de Estudios en Diseño y Comunicación. Vol. 67, mayo. Con Arbitraje.

$>$ Cuadernos del Centro de Estudios en Diseño y Comunicación. [Ensayos]: Componentes del diseño audiovisual experimental. Gonzalo Aranda Toro y Alejandra Niedermaier: Prólogo | Alejandra Niedermaier: Introducción | María José Alcalde: Reflexión acerca del ejercicio audiovisual como medio de expresión del diseño gráfico experimental | Eugenia Álvarez Saavedra: El diseño en las representaciones audiovisuales de la etnia Mapuche | Laura Bertolotto Navarrete y Katherine Hetz Rodríguez: Reflexión respecto de la conexión entre la disciplina del diseño y la audiovisual, como factor estratégico de desarrollo | José Luis Cancio: Cerebus, un modelo de edición independiente | Rosa Chalkho: La música cinematográfica y la construcción del sentido en el film | Antonieta Clunes: Experimentación con medios análogos y su aplicación como recurso audiovisual, reflejo de un contexto latinoamericano | Daniela V. Di Bella: Ex Obra, la rematerialización de la imagen en movimiento | Pamela Petruska Gatica Ramírez: Ver y sentir (pantallas). Diseño, dispositivos y emoción | Ricardo Pérez Rivera: Acerca del método de la observación y algunos alcances al estudio experimental para la construcción de imágenes | Juan Manuel Pérez: Sobre subjetividades en la educación visual contemporánea: algunos componentes | Eduardo A. Russo: Aspectos intermediales de la enseñanza audiovisual. Un abordaje transversal, entre el cine y los nuevos medios | Gisela Massara, Camila Sabeckis y Eleonora Vallazza: Tendencias en el Cine Expandido Contemporáneo. (2018). Buenos Aires: Universidad de Palermo, Facultad de Diseño y Comunicación, Centro de Estudios en Diseño y Comunicación. Vol. 66, marzo. Con Arbitraje.

$>$ Cuadernos del Centro de Estudios en Diseño y Comunicación. [Ensayos]: Maestría en Diseño de la Universidad de Palermo [Catálogo de Tesis. 5 ${ }^{a}$ Edición. Ciclo 2014-2015]. (2017). Buenos Aires: Universidad de Palermo, Facultad de Diseño y Comunicación, Centro de Estudios en Diseño y Comunicación. Vol. 65, diciembre. Con Arbitraje.

$>$ Cuadernos del Centro de Estudios en Diseño y Comunicación. [Ensayos]: Los procesos emergentes en la enseñanza y la práctica del diseño. M. Veneziani: Prólogo | M. Veneziani: Moda y comida: Una alianza que predice hechos económicos | M. Buey Fernández: Involúcrame y entenderé | F. Bertuzzi y D. Escobar: El espíritu emprendedor. Un acercamiento al diseño independiente de moda y las oportunidades de crecimiento comercial 
en el contexto actual argentino |X. González Eliçabe: Arte popular y diseño: los atributos de un nuevo lujo | C. Eiriz: Creación y operaciones de transformación. Aportes para una retórica del diseño | P. M. Doria: Desafío creativo cooperativo | V. Fiorini: Nuevos escenarios de las prácticas del diseño de indumentaria en Latinoamérica. Conceptos, metodologías e innovación productiva en el marco de la contemporaneidad | R. Aras: Los nuevos aprendizajes del sujeto digital | L. Mastantuono: Tendencias hacia un cine medioambiental. Concientización de una producción y diseño sustentable | D. Di Bella: El cuerpo como territorio | V. Stefanini: La mirada propia. El autorretrato en la fotografía contemporánea | S. Faerm: Introducción | A. Fry, R. Alexander, and S. Ladhib: Los emprendimientos en Diseño en la economía post-recesión: Parson`s E Lab, la Incubadora de Negocios de Diseño | S. Faerm: Desarrollando un nuevo valor en diseño; del "qué" al "cómo" | A. Kurennaya: Moda como práctica, Moda como proceso: los principios del lenguaje como marco para entender el proceso de diseño | L. Beltran-Rubio: Colombia for Export: Johanna Ortiz, Pepa Pombo y la recreación de la identidad cultural para el mercado global de la moda | A. Fry, G. Goretti, S. Ladhib, E. Cianfanelli, and C. Overby: "Artesanías de avanzada" integradas con el saber hacer; el papel del valor intangible y el rol central del artesano en el artesanato de alta gama del siglo $21 \mid$ T. Werner and S. Faerm: El uso de medios comerciales para involucrar e impactar de manera positiva en las comunidades. (2017). Buenos Aires: Universidad de Palermo, Facultad de Diseño y Comunicación, Centro de Estudios en Diseño y Comunicación. Vol. 64, septiembre. Con Arbitraje.

$>$ Cuadernos del Centro de Estudios en Diseño y Comunicación. [Ensayos]: Programa de Investigación de la Facultad de Diseño y Comunicación [Catálogo de Investigaciones. $1^{\text {a }}$ Edición. Ciclo 2007-2015). Investigaciones (abstracts) organizadas por campos temáticos: a. Empresas y marcas | b. Medios y estrategias de comunicación |c. Nuevas tecnologías |d. Nuevos profesionales | e. Diseño y producción de objetos, espacios e imágenes |f. Pedagogía del diseño y las comunicaciones | g. Historia y tendencia. Selección de Investigaciones (completas): Patricia Dosio: Detección y abordaje de problemas o tendencias actuales en el arte y el diseño | Débora Belmes: Nuevas herramientas de la comunicación. Un estudio acerca del amor, la amistad, la educación y el trabajo en jóvenes universitarios | Eleonora Vallaza: El Found Footage como práctica del video-arte argentino de la última década | Andrés Olaizola: Alfabetización académica en entornos digitales | Marina Mendoza: Hacia la construcción de una ciudadanía mediática. Reflexiones sobre la influencia de las políticas neoliberales en la configuración de la comunicación pública argentina | Valeria Stefanini: Los modos de representación del cuerpo en la fotografía de moda. Producciones fotográficas de la Revista Catalogue. (2017). Buenos Aires: Universidad de Palermo, Facultad de Diseño y Comunicación, Centro de Estudios en Diseño y Comunicación. Vol. 63, julio. Con Arbitraje.

$>$ Cuadernos del Centro de Estudios en Diseño y Comunicación. [Ensayos]: Cine documental. Fernando Mazás: Prólogo | Igor Dimitri Gonçalves: Werner Herzog, documentales de viaje: Fata Morgana, La Soufrière, A la espera de una catástrofe inevitable, Wodaabe, Pastores del sol, Jag Mandir | Nerea González: La doble lectura de Canciones para después de una guerra explicada desde el marco teórico de las problemáticas del documental | Lucía Levis Bilsky: De artistas, consumidores y críticos: dinámicas del cambio, el gusto y 
la distinción en el campo artístico actual. Jean-Luc Godard y su Adiós al Lenguaje |Claudia Martins: Péter Forgács: imágenes de familia y la memoria del Holocausto | Fernando Mazás: Edificio Master: la tecnología audiovisual como escritura étnica | Carlos Gustavo Motta: La antropología visual | Gonzalo Murúa Losada: Por un cuarto cine, el webdoc en la era de las narraciones digitales | Antonio Romero Zurita: El cine intelectual de Fernando Birri. Antecedentes a la conformación del Documental Militante en Argentina | Maria A. Sifontes: El acto performático como expresión del pensamiento en obras realizadas por artistas venezolanos. (2017). Buenos Aires: Universidad de Palermo, Facultad de Diseño y Comunicación, Centro de Estudios en Diseño y Comunicación. Vol. 62, mayo. Con Arbitraje.

> Cuadernos del Centro de Estudios en Diseño y Comunicación. [Ensayos]: Imágenes/ escrituras: trazos reversibles. Laura Ruiz y Marcos Zangrandi: Presentación. El lazo imagen/escritura en los nexos de la cultura contemporánea. 1. Blogs/escrituras. Diego Vigna: Lo narrado en imágenes (o las imágenes narradas). Ficciones, pruebas, trazos y fotografías en las publicaciones de los escritores en blogs | Mariana Catalin: Daniel Link y la televisión: ensayos entre la clase y la cualificación. 2. Cine/escrituras. Vanina Escales: El ensayo a la búsqueda de la imagen | Diego A. Moreiras: Dimensiones de una masacre en la escuela: traducción intersemiótica en We need to talk about Kevin| Nicolás Suárez: Pueblo, comunidad y mito en Juan Moreira de Leonardo Favio y en Facundo. La sombra del Tigre de Nicolás Sarquís | Marcos Zangrandi: Antín / Cortázar: cruces y destiempos entre la escritura y el cine. 3. Imágenes/escrituras. Álvaro Fernández Bravo: Imágenes, trauma, memoria: miradas del pasado reciente en obras de Patricio Guzmán, Adriana Lestido y Gustavo Germano | Laura Ruiz: Bronce y sueños, los gitanos. Nomadismo, identidades por exclusión y otredad negativa en Jorge Nedich y Josef Koudelka | Santiago Ruiz y Ximena Triquell: Imágenes y palabras en la lucha por imposición de sentidos: la imagen como generadora de relatos. (2017). Buenos Aires: Universidad de Palermo, Facultad de Diseño y Comunicación, Centro de Estudios en Diseño y Comunicación. Vol. 61, marzo. Con Arbitraje.

$>$ Cuadernos del Centro de Estudios en Diseño y Comunicación. [Ensayos]: Lecturas y poéticas del arte latinoamericano: apropiaciones, rupturas y continuidades. María Gabriela Figueroa: Prólogo | Cecilia Iida: El arte local en el contexto global | Silvia Dolinko: Lecturas sobre el grabado en la Argentina a mediados del siglo XX | Ana Hib: Repertorio de artistas mujeres en la historiografía canónica del arte argentino: un panorama de encuentros y desencuentros | Cecilia Marina Slaby: Mito y banalización: el arte precolombino en el arte actual. La obra de Rimer Cardillo y su apropiación de la iconografía prehispánica | Lucía Acosta: Jorge Prelorán: las voces que aún podemos escuchar| Luz Horne: Un paisaje nuevo de lo posible. Hacia una conceptualización de la "ficción documental" a partir de Fotografías, de Andrés Di Tella | María Cristina Rossi: Redes latinoamericanas de arte constructivo | Florencia Garramuño: Todos somos antropófagos. Sobrevivencias de una vocación internacionalista en la cultura brasileña | Jazmín Adler: Artes electrónicas en Argentina. En busca del eslabón perdido. (2016). Buenos Aires: Universidad de Palermo, Facultad de Diseño y Comunicación, Centro de Estudios en Diseño y Comunicación. Vol. 60, diciembre. Con Arbitraje. 
$>$ Cuadernos del Centro de Estudios en Diseño y Comunicación. [Ensayos]: La experiencia fotográfica en diálogo con las experiencias del mundo. Alejandra Niedermaier: Prólogo | François Soulages: Geoestética de idas-vueltas (a modo de introducción) | Eric Bonnet: Partir y volver. Cuba, tierra natal de Wifredo Lam y Ana Mendieta | María Aurelia Di Berardino: Lo que oculta una frontera: el para qué escindir la ciencia del arte | Alejandro Erbetta: La experiencia migratoria como posibilidad de creación | Raquel Fonseca: En la frontera de las imágenes de una inmigración en doble sentido; ida y vuelta | Denise Labraga: Fronteras blandas. Posibilidades de representación del horror | Alejandra Niedermaier: La imagen síntoma: construcciones estéticas del yo | Pedro San Ginés Aguilar: Hijo de la migración | Silvia Solas: Fronteras artísticas: sentidos y sinsentidos de lo visual | François Soulages: Las fronteras \& el ida-vuelta | Joaquim Viana: Las transformaciones diagramáticas: imágenes y fronteras efímeras. (2016). Buenos Aires: Universidad de Palermo, Facultad de Diseño y Comunicación, Centro de Estudios en Diseño y Comunicación. Vol. 59, septiembre. Con Arbitraje.

$>$ Cuadernos del Centro de Estudios en Diseño y Comunicación. [Ensayos]: Cine y Moda. P. Doria: Prólogo Universidad de Palermo | M. Carlos: Moda en cine: signos y simbolismos | D. Ceccato: Cortos de moda, un género en auge | P. Doria: Brillos y utopías |V. Fiorini: Moda, cuerpo y cine | C. Garizoain: De la pasarela al cine, del cine a la pasarela. El vestuario y la moda en el cine argentino hoy | M. Orta: Moda fantástica | S. Roffe: Vestuario de cine: El relator silencioso | M. Veneziani: Moda y cine: entre el relato y el ropaje | L. Acar: La seducción del cuerpo vestido en La fuente de las mujeres | F. di Cola: Moda y autenticidad histórica en el cine: nuevos ecos de la escuela viscontina $\mid \mathrm{E}$. Monteiro: El amor, los cuerpos y las ropas en Michael Haneke | D. Trindade: Vestes del tiempo: telas, movimientos e intervalos en la película Lavoura Arcaica | N. Villaça: Almodóvar: Cineasta y diseñador |F. Mazás: El cine come metalenguaje. Haciendo visible el código de la moda | Cuerpo, Arte y Diseño. P. Doria: Prólogo Universidad de Palermo | S. Cornejo y P. Estebecorena: Cuerpo, imagen e identidad. Relación (im)perfecta | D. Ceccato: Cuerpos encriptadas: Entre el ser real e irreal | L. Garabieta: Cuerpo y tiempo | G. Gómez del Río: Nuevos soportes, nuevos cuerpos | M. Matarrese: Cestería pilagá: una aproximación desde la estética al cuerpo | C. Puppo: El arte de diseñar nuestro cuerpo | S. Roffe: Ingeniería y arquitectura de la Moda: El cuerpo rediseñado | L. Ruiz: Imágenes de la otredad. Arte, política y cuerpos residuales en Daniel Santoro | V. Suárez: Cuerpos: utopías de lo real | S. Avelar: El futuro de la moda: una discusión posible | S. M. Costa, Esteban F. Tuesta \& S. A. Costa: Residuos agro-industriales utilizados como materiasprimas en estudios de desarrollo de fibras textiles | F. Dantas Mendes: El Diseño como estrategia de Postponement en la MVM Manufactura del Vestuario de la Moda | B. Ferreira Pires: Cuerpo trazado. Contexturas orgánicas e inorgánicas | C. R. Garcia Vicentini: El lugar de la creatividad en el desarrollo de productos de moda contemporáneos. (2016). Buenos Aires: Universidad de Palermo, Facultad de Diseño y Comunicación, Centro de Estudios en Diseño y Comunicación. Vol. 58, julio. Con Arbitraje.

$>$ Cuadernos del Centro de Estudios en Diseño y Comunicación. [Ensayos]: Moda en el siglo XX: una mirada desde las artes, los medios y la tecnología. Matilde Carlos: Prólogo | 
Melisa Perez y Perez: Las asociaciones entre el arte y la moda en el siglo XX | Mónica Silvia Incorvaia: La fotografía en la moda. Entre la seducción y el encanto | Gladys Mercado: Vestuario: entre el cine y la moda | Gabriela Gómez del Río: Fotolectos: cuando la imagen se vuelve espacio. Estudio de caso Para Ti Colecciones | Valeria Tuozzo: La moda en las sociedades modernas | Esteban Maioli: Moda, cuerpo e industria. Una revisión sobre la industria de la moda, el uso generalizado de TICs y la Tercera Revolución Industrial Informacional | Las Pymes y el mundo de la comunicación y los negocios. Patricia Iurcovich: Prólogo | Liliana Devoto: La sustentabilidad en las pymes, ¿es posible? | Sonia Grotz: Cómo transformar un sueño en un proyecto | María A. Rosa Dominici: La importancia del coaching en las PYMES como factor estratégico de cambio | Victoria Mejuto: La creación de diseño y marca en las Pymes | Diana Silveira: Las pymes argentinas: realidades y perspectivas | Christian Javier Klyver: Las Redes Sociales y las PyMES. Una relación productiva | Silvia Martinica: El maltrato psicológico en la empresa | Debora Shapira: La sucesión en las PYMES, el factor gerenciamiento. (2016). Buenos Aires: Universidad de Palermo, Facultad de Diseño y Comunicación, Centro de Estudios en Diseño y Comunicación. Vol. 57, marzo. Con Arbitraje.

$>$ Cuadernos del Centro de Estudios en Diseño y Comunicación. [Ensayos]: Pedagogías y poéticas de la imagen. Julio César Goyes Narváez y Alejandra Niedermaier: Prólogo | Vanessa Brasil Campos Rodríguez: Una mirada al borde del precipicio. La fascinación por lo siniestro en el espectáculo de lo real (reality show) | Mônica Ferreira Mayrink: La escuela en escena: las películas como signos mediadores de la formación crítico-reflexiva de profesores | Jesús González Requena: De los textos yoicos a los textos simbólicos | Julio César Goyes Narváez: Audiovisualidad y subjetividad. Del icono a la imagen fílmica Alejandro Jaramillo Hoyos: Poética de la imagen - imagen poética | Leopoldo Lituma Agüero: Imagen, memoria y Nación. La historia del Perú en sus imágenes primigenias | Luis Martín Arias: ¿Qué queremos decir cuando decimos “imagen”? Una aproximación desde la teoría de las funciones del lenguaje | Luis Eduardo Motta R.: La imagen y su función didáctica en la educación artística $\mid$ Alejandra Niedermaier: Cuando me asalta el miedo, creo una imagen | Eduardo A. Russo: Dinámicas de pantalla, prácticas postespectatoriales y pedagogías de lo audiovisual | Viviana Suarez: Interferencias. Notas sobre el taller como territorio, la regla como posibilidad, la obra como médium | Lorenzo Javier Torres Hortelano: Aproximación a un modelo de representación virtual lúdico (MRVL). Virtual Self, narcisismo y ausencia de sentido. (2016). Buenos Aires: Universidad de Palermo, Facultad de Diseño y Comunicación, Centro de Estudios en Diseño y Comunicación. Vol. 56, marzo. Con Arbitraje.

$>$ Cuadernos del Centro de Estudios en Diseño y Comunicación. [Ensayos]: Maestría en Diseño de la Universidad de Palermo [Catálogo de Tesis. 4 ${ }^{a}$ Edición. Ciclo 2012-2013]. Tesis recomendada para su publicación: Mariluz Sarmiento: La relación entre la biónica y el diseño para los criterios de forma y función. (2015). Buenos Aires: Universidad de Palermo, Facultad de Diseño y Comunicación, Centro de Estudios en Diseño y Comunicación. Vol. 55, septiembre. Con Arbitraje. 
$>$ Cuadernos del Centro de Estudios en Diseño y Comunicación. [Ensayos]: Reflexiones sobre la imagen: un grito interminable e infinito. Jorge Couto: Prólogo | Joaquín Linne y Diego Basile: Adolescentes y redes sociales online. El photo sharing como motor de la sociabilidad | María José Bórquez: El Photoshop en guerra: algo más que un retoque cosmético | Virginia E. Zuleta: Una apertura de Pina. Algunas reflexiones en torno al documental de Wim Wenders | Lorena Steinberg: El funcionamiento indicial de la imagen en el nuevo cine documental latinoamericano | Fernando Mazás: Apuntes sobre el rol del audiovisual en una genealogía materialista de la representación | Florencia Larralde Armas: Las fotos sacadas de la ESMA por Victor Basterra en el Museo de Arte y Memoria de La Plata: el lugar de la imagen en los trabajos de la memoria de la última dictadura militar argentina | Tomás Frère Affanni: La imagen y la música. Apuntes a partir de El artista | Mariana Bavoleo: El Fileteado Porteño: motivos decorativos en el margen de la comunicación publicitaria | Mariela Acevedo: Una reflexión sobre los aportes de la Epistemología Feminista al campo de los estudios comunicacionales | Daniela Ceccato: Los blogs de moda como creadores de modelos estéticos | Natalia Garrido: Imagen digital y sitios de redes sociales en internet: ¿más allá de espectacularización de la vida cotidiana? | Eugenia Verónica Negreira: El color en la imagen: una relación del pasado - presente y futuro | Ayelén Zaretti: Cuerpos publicitarios: cuerpos de diseño. Las imágenes del cuerpo en el discurso publicitario de la televisión. Un análisis discursivo | Jorge Couto: La "belleza" im-posible visual/digital de las tapas de las revistas. Aportes de la biopolítica para entender su u-topia. (2015). Buenos Aires: Universidad de Palermo, Facultad de Diseño y Comunicación, Centro de Estudios en Diseño y Comunicación. Vol. 54, septiembre. Con Arbitraje.

$>$ Cuadernos del Centro de Estudios en Diseño y Comunicación. [Ensayos]: Interpretando el pensamiento de diseño del siglo XXI. Marisa Cuervo: Prólogo | Marcia Veneziani: Introducción Universidad de Palermo. Tendencias opuestas | Leandro Allochis: La mirada lúcida. Desafíos en la producción y recepción de imágenes en la comunicación contemporánea | Teresita Bonafina: Lo austero. ¿Un estilo de vida o una tendencia en la moda? | Florencia Bustingorry: Moda y distinción social. Reflexiones en torno a los sentidos atribuidos a la moda | Carlos Caram: Pedagogía del diseño: el proyecto del proyecto | Patricia M. Doria: Poética, e inspiración en Diseño de Indumentaria | Verónica Fiorini: Tendencias de consumo, innovación e identidad en la moda: Transformaciones en la enseñanza del diseño latinoamericano | Paola Gallarato: Buscando el vacío. Reflexiones entre líneas sobre la forma del espacio | Andrea Pol: Brand 2020. El futuro de las marcas | José E. Putruele y Marcia C. Veneziani: Sustentabilidad, diseño y reciclaje | Valeria Stefanini: La puesta en escena. Arte y representación | Steven Faerm: Introducción Parsons The New School for Design. Nuevos mundos extremos | David Caroll: El innovador transgresor: ser un explorador de Google Glass | Aaron Fry y Steven Faerm: Consumismo en los Estados Unidos de la post-recesión: la influencia de lo "Barato y Chic" en la percepción sobre la desigualdad de ingresos | Steven Faerm: Construyendo las mejores prácticas en la enseñanza del diseño de moda: sentido, preparación e impacto | Robert Kirkbride: Aguas arriba/Aguas Abajo | Jeffrey Lieber: Aprender haciendo | Karinna Nobbs y Gretchen Harnick: Un estudio exploratorio sobre el servicio al cliente 
en la moda. (2015). Buenos Aires: Universidad de Palermo, Facultad de Diseño y Comunicación, Centro de Estudios en Diseño y Comunicación. Vol. 53, julio. Con Arbitraje.

$>$ Cuadernos del Centro de Estudios en Diseño y Comunicación. [Ensayos]: Cincuenta años de soledad. Aspectos y reflexiones sobre el universo del video arte. E. Vallazza: Prólogo | S. Torrente Prieto: La sutura de lo ausente. El espec-tador como actor en el videoarte | G. Galuppo: Frente al vacío cuerpos, espacios y gestos en el videoarte | C. Sabeckis: El videoarte y su relación con las vanguardias históricas y cinematográficas | J. P. Lattanzi: La crisis de las grandes narrativas del arte en el audiovisual latinoamericano: apuntes sobre el cine experimental latinoamericano en las décadas de 1960 y 1970 | N. Sorrivas: El videoarte como herramienta pedagógica | M. Cantú: Archivos y video: no lo hemos comprendido todo | E. Vallazza: El video arte y la ausencia de un campo cultural específico como respuesta a su hibridación artística $\mid$ D. Foresta: Los comienzos del videoarte (entrevista) | G. Ignoto: Borrado | J-P Fargier: Grand Canal \& Mon Eil! | R. Skryzak: Las ensoñaciones de un videasta solitario | G. Kortsarz: El sol en mi cabeza | La identidad nacional. Representaciones culturales en Argentina y Serbia. Z. Marzorati y B. Pantović: Prólogo | A. Mardikian: Múltiples identidades narrativas en el espacio teatral | D. Radojičić: Identidad cultural. La película etnográfica en Serbia $\mid$ M. Pombo: La fotografía argentina contemporánea. Una mirada hacia las comunidades indígenas | T. Tal: El Kruce de los Andes: memoria de San Martín y discurso político en Revolución (Ipiña, 2010) | B. Pantović: Serbia en imágenes: mensajes visuales de un país | V. Trifunović y J. Diković: La transformación post-socialista y la cultura popular: reflejo de la transición en series televisivas de Serbia | S. Sasiain: Espacios que educan: tres momentos en la historia de la educación en Argentina $\mid$ M. E. Stella: A un cuarto de siglo, reflexiones sobre el Juicio a las Juntas Militares en Argentina| A. Stagnaro: Representaciones culturales e identitarias en cambio: habitus científico y políticas públicas en ciencia y tecnología en la Argentina | A. Pavićević: El Ángel Blanco. Desde Heraldo de la Resurrección hasta Portador de Fortuna. Comercialización del Arte Religioso en la Serbia post-comunista $\mid$ M. Stefanović Banović: Ejemplos del uso de los símbolos cristianos en la vida cotidiana en Serbia (2015). Buenos Aires: Universidad de Palermo, Facultad de Diseño y Comunicación, Centro de Estudios en Diseño y Comunicación. Vol. 52, mayo. Con Arbitraje.

$>$ Cuadernos del Centro de Estudios en Diseño y Comunicación. [Ensayos]: Diseño de arte Tecnológico. Alejandra Niedermaier: Prólogo. Apartado: Acerca de FASE: Marcela Andino: Diseño de políticas culturales | Pelusa Borthwick: Nuestra inserción en la cadena de producción nacional | Patricia Moreira: FASE La necesidad del encuentro | Graciela Taquini: Textos curatoriales de los últimos cinco años de FASE. Apartado: Acerca de la esencia y el diseño del arte tecnológico. Rodrigo Alonso: Introducción a las instalaciones interactivas | Emiliano Causa: Cuerpo, Movimiento y Algoritmo | Rosa Chalhko: Entre al álbum y el MP3: variaciones en las tecnologías y las escuchas sociales | Alejandra Marinaro y Romina Flores: Objetos de frontera y arte tecnológico | Enrique Rivera Gallardo: El Virus de la Destrucción, o la defensa de lo inútil | Mariela Yeregui: Encrucijadas de las artes electrónicas en la aporía arte/investigación | Jorge Zuzulich: ¿Qué nos dice una 
obra de arte electrónico? Este cuaderno acompaña a FASE 6.0/2014. Tesis recomendada para su publicación. Valeria de Montserrat Gil Cruz: Gráficos animados en diarios digitales de México. Cápsulas informativas, participativas y de carácter lúdico. (2015). Buenos Aires: Universidad de Palermo, Facultad de Diseño y Comunicación, Centro de Estudios en Diseño y Comunicación. Vol. 51, marzo. Con Arbitraje.

$>$ Cuadernos del Centro de Estudios en Diseño y Comunicación. [Ensayos]: Diseños escénicos innovadores en puestas contemporáneas. Catalina Julia Artesi: Prólogo | Andrea Pontoriero: Vida líquida, teatro y narración en las propuestas escénicas de Mariano Pensotti | Estela Castronuovo: Lote 77 de Marcelo Mininno: el trabajoso oficio de narrar una identidad | Catalina Julia Artesi: Representaciones expandidas en puestas actuales | Ezequiel Lozano: La intermedialidad en el centro de las propuestas escénicas de Diego Casado Rubio | Marcelo Velázquez: Mediatización y diferencia. La búsqueda de la forma para una puesta en escena de Acreedores de Strindberg | Distribución cultural. Yanina Leandra: Prólogo | Andrea Hanna: El rol del productor en el teatro independiente. La producción es ejecutiva y algo más... | Roberto Perinelli: Teatro: de Independiente a Alternativo. Una síntesis del camino del Teatro Independiente argentino hacia la condición de alternativo y otras cuestiones inevitables | Leila Barenboim: Gestión Cultural 3.0 | Rosalía Celentano: Ámbito público, ámbito privado, ámbito independiente, fronteras desplazadas en el teatro de la Ciudad de Buenos Aires | Yoska Lazaro: La resignificación del término "producto" en el ámbito cultural | Tesis recomendada para su publicación: Rosa Judith Chalkho. Diseño sonoro y producción de sentido: la significación de los sonidos en los lenguajes audiovisuales (2014). Buenos Aires: Universidad de Palermo, Facultad de Diseño y Comunicación, Centro de Estudios en Diseño y Comunicación. Vol. 50, diciembre. Con Arbitraje.

$>$ Cuadernos del Centro de Estudios en Diseño y Comunicación. [Ensayos]: El Diseño en foco: modelos y reflexiones sobre el campo disciplinar y la enseñanza del diseño en América Latina. María Elena Onofre: Prólogo | Sandra Navarrete: Abstracción y expresión. Una reflexión de base filosófica sobre los procesos de diseño | Octavio Mercado G: Notas para un diseño negativo. Arte y política en el proceso de conformación del campo del Diseño Gráfico | Denise Dantas: Diseño centrado en el sujeto: una visión holística del diseño rumbo a la responsabilidad social | Sandra Navarrete: Diseño paramétrico. El gran desafío del siglo XXI | Deyanira Bedolla Pereda y Aarón José Caballero Quiroz: La imagen emotiva como lenguaje de la creatividad e innovación | María González de Cossío y Nora A. Morales Zaragoza: El pensamiento proyectual sistémico y su integración en el aula | Luis Rodríguez Morales: Hacia un diseño integral | Gloria Angélica Martínez de la Peña: La investigación y el diagnóstico de proyectos de diseño | María Isabel Martínez Galindo y Nora A. Morales Zaragoza: Imaginando otras formas de leer. La era de la sociedad imaginante | Paula Visoná y Giulio Palmitessa: Metodologías del diseño en la promoción de aprendizaje organizacional. El proyecto Melissa Academy | Leandro Brizuela: El diseño de packaging y su contribución al desarrollo de pequeños y medianos emprendimientos | Dolores Delucchi: El Diseño y su incidencia en la industria del juguete argentino | Pablo Capurro: Sin nadie en el medio. El papel de internet como intermediario en las industrias culturales y en la educación | Fabio Parode e Ione Bentz: 
El desarrollo sustentable en Brasil: cultura, medio ambiente y diseño. (2014). Buenos Aires: Universidad de Palermo, Facultad de Diseño y Comunicación, Centro de Estudios en Diseño y Comunicación. Vol. 49, septiembre. Con Arbitraje.

$>$ Cuadernos del Centro de Estudios en Diseño y Comunicación. [Ensayos]: Los enfoques multidisciplinarios del sistema de la moda. Marisa Cuervo: Prólogo | Marcia Veneziani: Introducción Universidad de Palermo. El enfoque multidisciplinario: un desafío pedagógico en la enseñanza de la moda y el diseño | Leandro Allochis: De New York a Buenos Aires y del Hip Hop a la Cumbia Villera. El protagonismo de la imagen en los procesos de transculturación | Patricia Doria: Sobre la Enseñanza del Diseño de Indumentaria. El desafío creativo (enseñanza del método) | Ximena González Eliçabe: Arte sartorial. De lo ritual a lo cotidiano | Sofía Marré: El asociativismo en las empresas de diseño de indumentaria de autor en Argentina | Laureano Mon: Los caminos de la innovación en la Argentina | Marcia Veneziani: Costumbres, dinero y códigos culturales: conceptos inseparables para la enseñanza del sistema de la moda | Maximiliano Zito: La ética del diseño sustentable. Steven Faerm: Introducción Parsons The New School for Design. Industria y Academia | Lauren Downing Peters: ¿Moda o vestido? Aspectos Pedagógicos en la teoría de la moda | Steven Faerm: Del aula al salón de diseño: La experiencia transicional del graduado en diseño de indumentaria | Aaron Fry, Steven Faerm y Reina Arakji: Realizando el sueño del nuevo graduado: construyendo el éxito sostenible de negocios en pequeña escala | Robert Kirkbride: Velos y veladuras | Melinda Wax: Meditaciones sobre una simple puntada. (2014). Buenos Aires: Universidad de Palermo, Facultad de Diseño y Comunicación, Centro de Estudios en Diseño y Comunicación. Vol. 48, junio. Con Arbitraje.

$>$ Cuadernos del Centro de Estudios en Diseño y Comunicación. [Ensayos]: Tejiendo identidades latinoamericanas. Marcia Veneziani: Prólogo | Manuel Carballo: Identidades: construcción y cambio | Roberto Aras: “Ortega, profeta del destino latinoamericano: la identidad como 'autenticidad" | Marisa García: Latinoamérica según Latinoamérica Leandro Allochis: La fotografía invisible. Identidad y tapas de revistas femeninas en la Argentina | Valeria Stefanini Zavallo: Pararse derechita. El cuerpo y la pose en la fotografía de moda. Un análisis de producciones fotográficas de la revista Catalogue | Marcia Veneziani: Diseñar a partir de la identidad. Entre el molde y el espejo | Paola de la Sotta Lazzerini - Osvaldo Muñoz Peralta: La intención de diseño. El caso del Artilugio Chilote | Ximena González Eliçabe: Arte textil y tradición en la Provincia de Catamarca, noroeste argentino | Lida Eugenia Lora Gómez - Diana Carolina Aconcha Díaz: FIBRARTE | Marina Porrúa: Claves de identidad del programa Identidades Productivas | Marina Porrúa: Diseño con identidad local. Territorio y cultura, como eje para el desarrollo y la sustentabilidad | Georgina Colzani: Entramado: moda y diseño en Latinoamérica | Andrea Melenje Argote: Itinerario: Diseño Gráfico, Cultura Visual e identidades locales | Nicolás García Recoaro: Las cholas y su mundo de polleras. (2014). Buenos Aires: Universidad de Palermo, Facultad de Diseño y Comunicación, Centro de Estudios en Diseño y Comunicación. Vol. 47, marzo. Con Arbitraje. 
$>$ Cuadernos del Centro de Estudios en Diseño y Comunicación. [Ensayos]: Maestría en Diseño de la Universidad de Palermo [Catálogo de Tesis. 3a Edición. Ciclo 2010-2011]. Tesis recomendada para su publicación: Yina Lissete Santisteban Balaguera: La influencia de los materiales en el significado de la joya. (2013). Buenos Aires: Universidad de Palermo, Facultad de Diseño y Comunicación, Centro de Estudios en Diseño y Comunicación. Vol. 46, diciembre. Con Arbitraje.

$>$ Cuadernos del Centro de Estudios en Diseño y Comunicación. [Ensayos]: Transformaciones en la comunicación, el arte y la cultura a partir del desarrollo y consolidación de nuevas tecnologías. T. Domenech: Prólogo | J. P. Lattanzi: ¿El poder de las nuevas tecnologías o las nuevas tecnologías y el poder? | G. Massara: Arte y nuevas tecnologías, lo experimental en el bioarte | E. Vallazza: Nuevas tecnologías, arte y activismo político | C. Sabeckis: El séptimo arte en la era de la revolución tecnológica | V. Levato: Redes sociales, lenguaje y tecnología Facebook. The 4th Estate Media? | M. Damoni: Democracia y mass media... ¿mayor calidad de la información? | N. Rivero: La literatura en su época de reproductibilidad digital | M. de la P. Garberoglio: Literatura y nuevas tecnologías. Cambios en las nociones de lectura y escritura a partir de los weblogs $\mid$ T. Domenech: Políticas culturales y nuevas tecnologías - Aportes interdisciplinares en Diseño y Comunicación desde el marketing, los negocios y la administración. S. G. González: Prólogo | A. Bur: Marketing sustentable. Utilización del marketing sustentable en la industria textil y de la indumentaria | A. Bur: Moda, estilo y ciclo de vida de los productos de la industria textil | S. Cabrera: La fidelización del cliente en negocios de restauración | S. Cabrera: Marketing gastronómico. La experiencia de convertir el momento del consumo en un recuerdo memorable $\mid$ C. R. Cerezo: De la Auditoría Contable a la Auditoría de las Comunicaciones | D. Elstein: La importancia de la motivación económica | S. G. González: La reputación como ventaja competitiva sostenible | E. Lissi: Primero la estrategia, luego el marketing. ¿Cómo conseguir recursos en las ONGs? | E. Llamas: La naturaleza estratégica del proceso de branding $\mid$ D. A. Ontiveros: Retail marketing: el punto de venta, un medio poderoso $\mid$ A. Prats: La importancia de la comunicación en el marketing interno. (2013). Buenos Aires: Universidad de Palermo, Facultad de Diseño y Comunicación, Centro de Estudios en Diseño y Comunicación. Vol. 45, septiembre. Con Arbitraje.

$>$ Cuadernos del Centro de Estudios en Diseño y Comunicación. [Ensayos]: Moda y Arte. Marcia Veneziani: Prólogo Universidad de Palermo | Felisa Pinto: Fusión Arte y Moda | Diana Avellaneda: De perfumes que brillan y joyas que huelen. Objetos de la moda y talismanes de la fe | Diego Guerra y Marcelo Marino: Historias de familia. Retrato, indumentaria y moda en la construcción de la identidad a través de la colección Carlos Fernández y Fernández del Museo Fernández Blanco, 1870-1915 | Roberto E. Aras: Arte y moda: ¿fusión o encuentro? Reflexiones filosóficas | Marcia Veneziani: Moda y Arte en el diseño de autor argentino | Laureano Mon: Diseño en Argentina. "Hacia la construcción de nuevos paradigmas" | Victoria Lescano: Baño, De Loof y Romero, tres revolucionarios de la moda y el arte en Buenos Aires | Valeria Stefanini Zavallo: Para hablar de mí. La apropiación que el arte hace de la moda para abordar el problema de la identidad de género | María Valeria Tuozzo y Paula López: Moda y Arte. Campos en intersección | 
Maria Giuseppina Muzzarelli: Prólogo Università di Bologna | Maria Giuseppina Muzzarelli: El binomio arte y moda: etapas de un proceso histórico | Simona Segre Reinach: Renacimiento y naturalización del gusto. Una paradoja de la moda italiana | Federica Muzzarelli: La aventura de la fotografía como arte de la moda | Elisa Tosi Brandi: El arte en el proceso creativo de la moda: algunas consideraciones a partir de un caso de estudio | Nicoletta Giusti: Art works: organizar el trabajo creativo en la moda y en el arte Antonella Mascio: La moda como forma de valorización de las series de televisión. (2013). Buenos Aires: Universidad de Palermo, Facultad de Diseño y Comunicación, Centro de Estudios en Diseño y Comunicación. Vol. 44, junio. Con Arbitraje.

$>$ Cuadernos del Centro de Estudios en Diseño y Comunicación. [Ensayos]: Acerca de la subjetividad contemporánea: evidencias y reflexiones. Alejandra Niedermaier - Viviana Polo Flórez: Prólogo | Raúl Horacio Lamas: La Phantasía estructurante del pensamiento y de la subjetividad | Alejandra Niedermaier: La distribución de lo inteligible y lo sensible hoy | Susana Pérez Tort: Poéticas visuales mediadas por la tecnología. La necesaria opacidad | Alberto Carlos Romero Moscoso: Subjetividades inestables | Norberto Salerno: ¿Qué tienen de nuevo las nuevas subjetividades? | Magalí Turkenich - Patricia Flores: Principales aportes de la perspectiva de género para el estudio social y reflexivo de la ciencia, la tecnología y la innovación | Gustavo Adolfo Aragón Holguín: Consideración de la escritura narrativa como indagación de sí mismo | Cayetano José Cruz García: Idear la forma. Capacitación creativa | Daniela V. Di Bella: Aspectos inquietantes de la era de la subjetividad: lo deseable y lo posible | Paola Galvis Pedroza: Del universo simbólico al arte como terapia. Un camino de descubrimientos | Julio César Goyes Narváez: El sujeto en la experiencia de lo real | Sylvia Valdés: Subjetividad, creatividad y acción colectiva | Elizabeth Vejarano Soto: La poética de la forma. Fronteras desdibujadas entre el cuerpo, la palabra y la cosa | Eduardo Vigovsky: Los aportes de la creatividad ante la dificultad reflexiva del estudiante universitario | Julián Humberto Arias: Desarrollo humano: un lugar epistémico | Lucía Basterrechea: Subjetividad en la didáctica de las carreras proyectuales. Grupos de aprendizaje; evaluación | Tatiana Cuéllar Torres: Cartografía del papel de los artefactos en la subjetividad infantil. Un caso sobre la implementación de artefactos en educación de la primera infancia | Rosmery Dussán Aguirre: El Diseño de experiencias significativas en entornos de aprendizaje | Orfa Garzón Rayo: Apuntes iniciales para pensar-se la subjetividad que se expresa en los procesos de docencia en la educación superior | Alfredo Gutiérrez Borrero: Rapsodia para los sujetos por sí-mismos. Hacia una sociedad de localización participante | Viviana Polo Florez: Habitancia y comunidades de sentido. Complejidad humana y educación. Consideraciones acerca del acto educativo en Diseño. (2013). Buenos Aires: Universidad de Palermo, Facultad de Diseño y Comunicación, Centro de Estudios en Diseño y Comunicación. Vol. 43, marzo. Con Arbitraje.

$>$ Cuadernos del Centro de Estudios en Diseño y Comunicación. [Ensayos]: Perspectivas sobre moda, tendencias, comunicación, consumo, diseño, arte, ciencia y tecnología. Marcia Veneziani: Prólogo | Laureano Mon: Industrias Creativas de Diseño de Indumentaria de Autor. Diagnóstico y desafíos a 10 años del surgimiento del fenómeno en Ar- 
gentina | Marina Pérez Zelaschi: Observatorio de tendencias | Sofía Marré: La propiedad intelectual y el diseño de indumentaria de autor | Diana Avellaneda: Telas con efectos mágicos: iconografía en las distintas culturas. Entre el arte, la moda y la comunicación | Silvina Rival: Tiempos modernos. Entre lo moderno y lo arcaico: el cine de Jia Zhang-ke y Hong Sang-soo | Cristina Amalia López: Moda, Diseño, Técnica y Arte reunidos en el concepto del buen vestir. La esencia del oficio y el lenguaje de las formas estéticas del arte sartorial y su aporte a la cultura y el consumo del diseño| Patricia Doria: Consideraciones sobre moda, estilo y tendencias | Gustavo A. Valdés de León: Filosofía desde el placard. Modernidad, moda e ideología | Mario Quintili: Nanociencia y Nanotecnología... un mundo pequeño | Diana Pagano: Las tecnologías de la felicidad privada. Una problemática tan vieja como la modernidad | Elena Onofre: Al compás de la revolución Interactiva. Un mundo de conexiones | Roberto Aras: Principios para una ética de la ficción televisiva | Valeria Stefanini Zavallo: El uso del cuerpo en las revistas de moda | Andrea Pol: La marca: un signo de identificación visual y auditivo sinérgico. (2012). Buenos Aires: Universidad de Palermo, Facultad de Diseño y Comunicación, Centro de Estudios en Diseño y Comunicación. Vol. 42, septiembre. Con Arbitraje.

$>$ Cuadernos del Centro de Estudios en Diseño y Comunicación. [Ensayos]: Arte, Diseño y medias tecnológicas. Rosa Chalkho: Hacia una proyectualidad crítica. [Prólogo] | Florencia Battiti: El arte ante las paradojas de la representación | Mariano Dagatti: El voyeurismo virtual. Aportes a un estudio de la intimidad | Claudio Eiriz: El oído tiene razones que la física no conoce. (De la falla técnica a la ruptura ontológica) | María Cecilia Guerra Lage: Redes imaginarias y ciudades globales. El caso del stencil en Buenos Aires (2000-2007) | Mónica Jacobo: Videojuegos y arte. Primeras manifestaciones de Game Art en Argentina | Jorge Kleiman: Automatismo \& Imago. Aportes a la Investigación de la Imagen Inconsciente en las Artes Plásticas | Gustavo Kortsarz: La duchampizzación del arte | María Ledesma: Enunciación de la letra. Un ejercicio entre Occidente y Oriente | José Llano: La notación del intérprete. La construcción de un paisaje cultural a modo de huella material sobre Valparaíso | Carmelo Saitta: La banda sonora, su unidad de sentido | Sylvia Valdés: Poéticas de la imagen digital. (2012) Buenos Aires: Universidad de Palermo, Facultad de Diseño y Comunicación, Centro de Estudios en Diseño y Comunicación. Vol. 41, junio. Con Arbitraje.

$>$ Cuadernos del Centro de Estudios en Diseño y Comunicación. [Ensayos]: Relaciones Públicas al sur de Latinoamerica II. Una mirada regional de los nuevos escenarios y desafíos de la comunicación. Marisa Cuervo: Prólogo | Claudia Gil Cubillos: Presentación | Fernando Caniza: Lo público y lo privado en las Relaciones Públicas. Cómo pensar la identidad y pertenencia del alumno en estos ámbitos para comprender mejor su desempeño académico y su inserción profesional | Gustavo Cóppola: Gestión del Riesgo Comunicacional. Puesta en práctica | Maria Aparecida Ferrari: Comunicación y Cultura: análisis de la realidad de las Relaciones Públicas en organizaciones chilenas y brasileñas | Constanza Hormazábal: Reputación y manejo de Crisis: Caso empresas de telefonía móvil, luego del 27F en Chile | Patricia Iurcovich: La Pequeña y Mediana empresa y la función de la comunicación | Carina Mazzola: Repensar la comunicación 
en las organizaciones. Del pensamiento en línea hacia una mirada sobre la complejidad de las prácticas comunicacionales | André Menanteau: Transparencia y comunicación financiera | Edison Otero: Tecnología y organizaciones: de la comprensión a la intervención | Gabriela Pagani: ¿Se puede ser una empresa socialmente responsable sin comunicar? | Julio Reyes: Las Cuatro Dimensiones de la Comunicación Interna. (2012) Buenos Aires: Universidad de Palermo, Facultad de Diseño y Comunicación, Centro de Estudios en Diseño y Comunicación. Vol. 40, abril. Con Arbitraje.

$>$ Cuadernos del Centro de Estudios en Diseño y Comunicación. [Ensayos]: Alquimia de lenguajes: alfabetización, enunciación y comunicación. Alejandra Niedermaier: Prólogo | Eje: La alfabetización de las distintas disciplinas. Beatriz Robles. Bernardo Suárez. Claudio Eiriz. Gustavo A. Valdés de León. Mara Steiner. Hugo Salas. Fernando Luis Rolando Badell. María Torre. Daniel Tubío | Eje: Vasos comunicantes. Norberto Salerno. Viviana Suárez. Laura Gutman. Graciela Taquini. Alejandra Niedermaier | Eje: Nuevos modos de circulación, nuevos modos de comunicación. Débora Belmes. Verónica Devalle. Mercedes Pombo. Eduardo Russo. Verónica Joly. (2012) Buenos Aires: Universidad de Palermo, Facultad de Diseño y Comunicación, Centro de Estudios en Diseño y Comunicación. Vol. 39, marzo. Con Arbitraje.

$>$ Cuadernos del Centro de Estudios en Diseño y Comunicación. [Ensayos]: Maestría en Diseño de la Universidad de Palermo [Catálogo de Tesis. 2a Edición. Ciclo 2008-2009]. Tesis recomendada para su publicación: Paola Andrea Castillo Beltrán: Criterios transdiciplinares para el diseño de objetos lúdico-didácticos. (2011) Buenos Aires: Universidad de Palermo, Facultad de Diseño y Comunicación, Centro de Estudios en Diseño y Comunicación. Vol. 38, diciembre. Con Arbitraje.

$>$ Cuadernos del Centro de Estudios en Diseño y Comunicación. [Ensayos]: El Diseño de Interiores en la Historia. Roberto Céspedes: El Diseño de Interiores en la Historia. Andrea Peresan Martínez: Antigüedad. Alberto Martín Isidoro: Bizancio. Alejandra Palermo: Alta Edad Media: Románico. Alicia Dios: Baja Edad Media: Gótico. Ana Cravino: Renacimiento, Manierismo, Barroco. Clelia Mirna Domoñi: Iberoamericano Colonial. Gabriela Garófalo: Siglo XIX. Mercedes Pombo: Siglo XX. Maestría en Diseño de la Universidad de Palermo. Tesis recomendada para su publicación. Mauricio León Rincón: El relato de ciencia ficción como herramienta para el diseño industrial. (2011) Buenos Aires: Universidad de Palermo, Facultad de Diseño y Comunicación, Centro de Estudios en Diseño y Comunicación. Vol. 37, septiembre. Con Arbitraje.

> Cuadernos del Centro de Estudios en Diseño y Comunicación. [Ensayos]: Picas (2011) Buenos Aires: Universidad de Palermo, Facultad de Diseño y Comunicación, Centro de Estudios en Diseño y Comunicación. Vol. 36, junio. Con Arbitraje.

$>$ Cuadernos del Centro de Estudios en Diseño y Comunicación. [Ensayos]: Relaciones Públicas, nuevos paradigmas ¿más dudas que certezas? Paola Lattuada: Relaciones Públicas, nuevos paradigmas ¿más dudas que certezas? Fernando Arango: Comunica- 
ciones corporativas. Damián Martínez Lahitou: Brand PR: comunicaciones de marca. Manuel Montaner Rodríguez: La gestión de las PR a través de Twitter. Orlando Daniel Di Pino: Avanza la tecnología, que se salve el contenido! Lucas Lanza y Natalia Fidel: Política 2.0 y la comunicación en tiempos modernos. Daniel Néstor Yasky: Los públicos de las comunicaciones financieras. Investor relations \& financial communications. Andrea Paula Lojo: Los públicos internos en la construcción de la imagen corporativa. Gustavo Adrián Pedace: Las Relaciones Públicas y la mentira: ¿inseparables? Gabriel Pablo Stortini: La ética en las Relaciones Públicas. Gerardo Sanguine: Las prácticas profesionales en la carrera de Relaciones Públicas. Paola Lattuada: Comunicación Sustentable: la posibilidad de construir sentido con otros. Adriana Lauro: RSE - Comunicación para el Desarrollo Sostenible en una empresa de servicio básico y social: Caso Aysa. (2011) Buenos Aires: Universidad de Palermo, Facultad de Diseño y Comunicación, Centro de Estudios en Diseño y Comunicación. Vol. 35, marzo. Con Arbitraje.

$>$ Cuadernos del Centro de Estudios en Diseño y Comunicación. [Ensayos]: La utilización de clásicos en la puesta en escena. Catalina Artesi: Tensión entre los ejes de lo clásico y lo contemporáneo en dos versiones escénicas de directores argentinos. Andrés Olaizola: La Celestina en la versión de Daniel Suárez Marzal: apuntes sobre su puesta en escena. María Laura Pereyra: Antígona, desde el teatro clásico al Derecho Puro - Perspectivas de la enseñanza a través del método del case study. María Laura Ríos: Manifiesto de Niños, o la escenificación de la violencia. Mariano Saba: Pelayo y el gran teatro del canon: los condicionamientos críticos de Unamuno dramaturgo según su recepción en América Latina. Propuestas de abordaje frente a las problemáticas de la diversidad. Nuevas estrategias en educación superior, desarrollo turístico y comunicación. Florencia Bustingorry: Sin barreras lingüísticas en el aula. La universidad argentina como escenario del multiculturalismo. Diego Navarro: Turismo: portal de la diversidad cultural. El turismo receptivo como espacio para el encuentro multicultural. Virginia Pineau: La Educación Superior como un espacio de construcción del Patrimonio Cultural. Una forma de entender la diversidad. Irene Scaletzky: La construcción del espacio académico: ciencia y diversidad. Maestría en Diseño de la Universidad de Palermo. Tesis recomendada para su publicación. Yaffa Nahir I. Gómez Barrera: La Cultura del Diseño, estrategia para la generación de valor e innovación en la PyMe del Área Metropolitana del Centro Occidente, Colombia. (2010) Buenos Aires: Universidad de Palermo, Facultad de Diseño y Comunicación, Centro de Estudios en Diseño y Comunicación. Vol. 34, diciembre. Con Arbitraje.

$>$ Cuadernos del Centro de Estudios en Diseño y Comunicación. [Ensayos]: Relaciones Públicas, al sur de Latinoamérica. Paola Lattuada: Relaciones Públicas, al sur de Latinoamérica. Daniel Scheinsohn: Comunicación Estratégica ${ }^{\circledR}$. María Isabel Muñoz Antonin: Reputación corporativa: Trustmark y activo de comportamientos adquisitivos futuros. Bernardo García: Tendencias y desafíos de las marcas globales. Nuevas expectativas sobre el rol del comunicador corporativo. Claudia Gil Cubillos: Comunicadores corporativos: desafíos de una formación profesional por competencias en la era global. Marcelino Garay Madariaga: Comunicación y liderazgo: sin comunicación no hay líder. Jairo Ortiz Gonzales: El rol del comunicador en la era digital. Alberto Arébalos: Las nuevas 
relaciones con los medios. En un mundo de comunicaciones directas, ¿es necesario hacer media relations? Enrique Correa Ríos: Comunicación y lobby. Guillermo Holzmann: Comunicación política y calidad democrática en Latinoamérica. Paola Lattuada: RSE y RRPP: ¿un mismo ADN? Equipo de Comunicaciones Corporativas de MasterCard para la región de Latinoamérica y el Caribe: RSE - Caso líder en consumo inteligente. (2010) Buenos Aires: Universidad de Palermo, Facultad de Diseño y Comunicación, Centro de Estudios en Diseño y Comunicación. Vol. 33, agosto. Con Arbitraje.

> Cuadernos del Centro de Estudios en Diseño y Comunicación. [Ensayos]: txts. (2010) Buenos Aires: Universidad de Palermo, Facultad de Diseño y Comunicación, Centro de Estudios en Diseño y Comunicación. Vol. 32, mayo. Con Arbitraje.

$>$ Cuadernos del Centro de Estudios en Diseño y Comunicación. [Ensayos]: Maestría en Diseño de la Universidad de Palermo [Catálogo de Tesis. $1^{\text {a }}$ Edición. Ciclo 2004-2007]. Tesis recomendada para su publicación: Nancy Viviana Reinhardt: Infografía Didáctica: producción interdisciplinaria de infografías didácticas para la diversidad cultural. (2010) Buenos Aires: Universidad de Palermo, Facultad de Diseño y Comunicación, Centro de Estudios en Diseño y Comunicación. Vol. 31, abril. Con Arbitraje.

$>$ Cuadernos del Centro de Estudios en Diseño y Comunicación. [Ensayos]: El paisaje como referente de diseño. Jimena Martignoni: El paisaje como referente de diseño. Carlos Coccia: Escenografía. Teatro. Paisaje. Cristina Felsenhardt: Arquitectura. Paisaje. Graciela Novoa: Historia. Marcas a través del tiempo. Paisaje. Andrea Saltzman: Cuerpo. Vestido. Paisaje. Sandra Siviero: Antropología. Pueblos. Paisaje. Felipe Uribe de Bedout: Mobiliario Urbano. Espacio Público. Ciudad - Paisaje. Paisaje Urbe. Patricia Noemí Casco y Edgardo M. Ruiz: Introducción Paisaje Urbe. Manifiesto: Red Argentina del Paisaje. Lorena C. Allemanni: Acciones sobre el principal recurso turístico de Villa Gesell "la playa". Gabriela Benito: Paisaje como recurso ambiental. Gabriel Burgueño: El paisaje natural en el diseño de espacios verdes. Patricia Noemí Casco: Paisaje compartido. Paisaje como recurso. Fabio Márquez: Diseño participativo de espacios verdes públicos. Sebastián Miguel: Proyecto social en áreas marginales de la ciudad. Eduardo Otaviani: El espacio público, sostén de las relaciones sociales. Blanca Rotundo y María Isabel Pérez Molina: El hombre como hacedor del paisaje. Edgardo M. Ruiz: Patrimonio, historia y diseño de los jardines del Palacio San José. Fabio A. Solari y Laura Cazorla: Valoración de la calidad y fragilidad visual del paisaje. (2009) Buenos Aires: Universidad de Palermo, Facultad de Diseño y Comunicación, Centro de Estudios en Diseño y Comunicación. Vol. 30, noviembre. Con Arbitraje.

> Cuadernos del Centro de Estudios en Diseño y Comunicación. [Ensayos]: Typo. (2009) Buenos Aires: Universidad de Palermo, Facultad de Diseño y Comunicación, Centro de Estudios en Diseño y Comunicación. Vol. 29, agosto. Con Arbitraje.

$>$ Cuadernos del Centro de Estudios en Diseño y Comunicación. [Ensayos]: Relaciones Públicas 2009. Radiografía: proyecciones y desafíos. Paola Lattuada: Introducción. Fer- 
nando Arango: La medición de la reputación corporativa. Alberto Arébalos: Yendo donde están las audiencias. Internet: el nuevo aliado de las relaciones públicas. Alessandro Barbosa Lima y Federico Rey Lennon: La Web 2.0: el nuevo espacio público. Lorenzo A. Blanco: entrevista. Lorenzo A. Blanco: ¿Nuevas empresas... nuevas tendencias... nuevas relaciones públicas...? Carlos Castro Zuñeda: La opinión pública como el gran grupo de interés de las relaciones públicas. Marisa Cuervo: El desafío de la comunicación interna en las organizaciones. Diego Dillenberger: Comunicación política. Graciela Fernández Ivern: Consejo Profesional de Relaciones Públicas de la República Argentina. Carta abierta en el $50^{\circ}$ aniversario. Juan Iramain: La sustentabilidad corporativa como objetivo estratégico de las relaciones públicas. Patricia Iurcovich: Las pymes y la función de la comunicación. Gabriela T. Kurincic: Convergencia de medios en Argentina. Paola Lattuada: RSE: Responsabilidad Social Empresaria. La tríada RSE. Aldo Leporatti: Issues Management. La comunicación de proyectos de inversión ambientalmente sensibles. Elisabeth Lewis Jones: El beneficio público de las relaciones públicas. Un escenario en el que todos ganan. Hernán Maurette: La comunicación con el gobierno. Allan McCrea Steele: Los nuevos caminos de la comunicación: las experiencias multisensoriales. Daniel Scheinsohn: Comunicación Estratégica ${ }^{\circledR}$. Roberto Starke: Lobby, lobistas y bicicletas. Hernán Stella: La comunicación de crisis. (2009) Buenos Aires: Universidad de Palermo, Facultad de Diseño y Comunicación, Centro de Estudios en Diseño y Comunicación. Vol. 28, abril. Con Arbitraje.

$>$ Cuadernos del Centro de Estudios en Diseño y Comunicación. [Ensayos]: Sandro Benedetto: Borges y la música. Alberto Farina: El cine en Borges. Alejandra Niedermaier: Algunas consideraciones sobre la fotografía a través de la cosmovisión de Jorge Luis Borges. Graciela Taquini: Transborges. Nora Tristezza: El arte de Borges. Florencia Bustingorry y Valeria Mugica: La fotografía como soporte de la memoria. Andrea Chame: Fotografía: los creadores de verdad o de ficción. Mónica Incorvaia: Fotografía y Realidad. Viviana Suárez: Imágenes opacas. La realidad a través de la máquina surrealista o el desplazamiento de la visión clara. Daniel Tubío: Innovación, imagen y realidad: ¿Sólo una cuestión de tecnologías? Augusto Zanela: La tecnología se sepulta a sí misma. (2008) Buenos Aires: Universidad de Palermo, Facultad de Diseño y Comunicación, Centro de Estudios en Diseño y Comunicación. Vol. 27, diciembre. Con Arbitraje.

$>$ Cuadernos del Centro de Estudios en Diseño y Comunicación. [Ensayos]: Catalina Julia Artesi: ¿Un Gardel venezolano? “El día que me quieras” de José Ignacio Cabrujas. Marcelo Bianchi Bustos: Latinoamérica: la tierra de Rulfo y de García Márquez. Reflexiones en torno a algunas cuestiones para pensar la identidad. Silvia Gago: Los límites del arte. María José Herrera: Arte Precolombino Andino. Alejandra Viviana Maddonni: Ricardo Carpani: arte, gráfica y militancia política. Alicia Poderti: La inserción de Latinoamérica en el mundo globalizado. Andrea Pontoriero: La identidad como proceso de construcción. Reapropiaciones de textualidades isabelinas a la luz de la farsa porteña. Gustavo Valdés de León: Latinoamérica en la trama del diseño. Entre la utopía y la realidad. (2008) Buenos Aires: Universidad de Palermo, Facultad de Diseño y Comunicación, Centro de Estudios en Diseño y Comunicación. Vol. 26, agosto. Con Arbitraje. 
$>$ Cuadernos del Centro de Estudios en Diseño y Comunicación. [Ensayos]: Guillermo Desimone. Sobreviviendo a la interferencia. Daniela V. Di Bella. Arte Tecnomedial: Programa curricular. Leonardo Maldonado. La aparición de la estrella en el cine clásico norteamericano. Su incidencia formal en la instancia enunciativa del film hollywoodense. (2008) Buenos Aires: Universidad de Palermo, Facultad de Diseño y Comunicación, Centro de Estudios en Diseño y Comunicación. Vol. 25, abril. Con Arbitraje.

$>$ Cuadernos del Centro de Estudios en Diseño y Comunicación. [Ensayos]: Rosa Judith Chalkho: Introducción: artes, tecnologías y huellas históricas. Norberto Cambiasso: El oído inalámbrico. Diseño sonoro, auralidad y tecnología en el futurismo italiano. Máximo Eseverri: La batalla por la forma. Belén Gache: Literatura y máquinas. Iliana Hernández García: Arquitectura, Diseño y nuevos medios: una perspectiva crítica en la obra de Antoni Muntadas. Fernando Luis Rolando: Arte, Diseño y nuevos medios. La variación de la noción de inmaterialidad en los territorios virtuales. Eduardo A. Russo: La movilización del ojo electrónico. Fronteras y continuidades en El arca rusa de Alexander Sokurov, o del plano cinematográfico y sus fundamentos (por fin cuestionados). Graciela Taquini: Ver del video. Daniel Varela: Algunos problemas en torno al concepto de música interactiva. (2007) Buenos Aires: Universidad de Palermo, Facultad de Diseño y Comunicación, Centro de Estudios en Diseño y Comunicación. Vol. 24, agosto. Con Arbitraje.

$>$ Cuadernos del Centro de Estudios en Diseño y Comunicación. [Ensayos]: Sebastián Gil Miranda. Entre la ética y la estética en la sociedad de consumo. La responsabilidad profesional en Diseño y Comunicación. Fabián Iriarte. Entre el déficit temático y el advenimiento del guionista compatible. Dante Palma. La inconmensurabilidad en la era de la comunicación. Reflexiones acerca del relativismo cultural y las comunidades cerradas. Viviana Suárez. El diseñador imaginario [La creatividad en las disciplinas de diseño]. Gustavo A. Valdés de León. Diseño experimental: una utopía posible. Marcos Zangrandi. Eslóganes televisivos: emergentes tautistas. (2007) Buenos Aires: Universidad de Palermo, Facultad de Diseño y Comunicación, Centro de Estudios en Diseño y Comunicación. Vol. 23, junio. Con Arbitraje.

$>$ Cuadernos del Centro de Estudios en Diseño y Comunicación. [Ensayos]: Sylvia Valdés. Diseño y Comunicación. Investigación de posgrado y hermenéutica. Daniela Chiappe. Medios de comunicación e-commerce. Análisis del contrato de lectura. Mariela D’Angelo. El signo icónico como elemento tipificador en la infografía. Noemí Galanternik. La intervención del Diseño en la representación de la información cultural: Análisis de la gráfica de los suplementos culturales de los diarios. María Eva Koziner. Diseño de Indumentaria argentino. Darnos a conocer al mundo. Julieta Sepich. La pasión mediática y mediatizada. Julieta Sepich. La producción televisiva. Retos del diseñador audiovisual. Marcelo Adrián Torres. Identidad y el patrimonio cultural. El caso de los sitios arqueológicos de la provincia de La Rioja. Marcela Verónica Zena. Representación de la cultura en el diario impreso: Análisis comunicacional. Facultad de Diseño y Comunicación. Universidad de Palermo. (2006) Buenos Aires: Universidad de Palermo, Facultad de Diseño y Comunicación, Centro de Estudios en Diseño y Comunicación. Vol. 22, noviembre. Con Arbitraje. 
$>$ Cuadernos del Centro de Estudios en Diseño y Comunicación. [Ensayos]: Oscar Echevarría. Proyecto Maestría en Diseño. Facultad de Diseño y Comunicación. Universidad de Palermo. (2006) Buenos Aires: Universidad de Palermo, Facultad de Diseño y Comunicación, Centro de Estudios en Diseño y Comunicación. Vol. 21, julio. Con Arbitraje.

$>$ Cuadernos del Centro de Estudios en Diseño y Comunicación. [Ensayos]: Rosa Chalkho. Arte y tecnología. Francisco Ali-Brouchoud. Música: Arte. Rodrigo Alonso. Arte, ciencia y tecnología. Vínculos y desarrollo en Argentina. Daniela Di Bella. El tercer dominio. Jorge Haro. La escucha expandida [sonido, tecnología, arte y contexto] Jorge La Ferla. Las artes mediáticas interactivas corroen el alma. Juan Reyes. Perpendicularidad entre arte sonoro y música. Jorge Sad. Apuntes para una semiología del gesto y la interacción musical. (2006) Buenos Aires: Universidad de Palermo, Facultad de Diseño y Comunicación, Centro de Estudios en Diseño y Comunicación. Vol. 20, mayo. Con Arbitraje.

$>$ Cuadernos del Centro de Estudios en Diseño y Comunicación. [Ensayos]: Trabajos Finales de Grado. Proyectos de Graduación. Facultad de Diseño y Comunicación. Universidad de Palermo. Catálogo 1993-2004. (2005) Buenos Aires: Universidad de Palermo, Facultad de Diseño y Comunicación, Centro de Estudios en Diseño y Comunicación. Vol. 19, agosto. Con Arbitraje.

$>$ Cuadernos del Centro de Estudios en Diseño y Comunicación. [Ensayos]: Sylvia Valdés. Cine latinoamericano. Leandro Africano. Funcionalidad actual del séptimo arte. Julián Daniel Gutiérrez Albilla. Los olvidados de Luis Buñuel. Geoffrey Kantaris. Visiones de la violencia en el cine urbano latinoamericano. Joanna Page. Memoria y experimentación en el cine argentino contempoáneo. Erica Segre. Nacionalismo cultural y Buñuel en méxico. Marina Sheppard. Cine y resistencia. (2005) Buenos Aires: Universidad de Palermo, Facultad de Diseño y Comunicación, Centro de Estudios en Diseño y Comunicación. Vol. 18, mayo. Con Arbitraje.

$>$ Cuadernos del Centro de Estudios en Diseño y Comunicación. [Ensayos]: Guía de Artículos y Publicaciones de la Facultad de Diseño y Comunicación de la Universidad de Palermo. 1993-2004. (2004) Buenos Aires: Universidad de Palermo, Facultad de Diseño y Comunicación, Centro de Estudios en Diseño y Comunicación. Vol. 17, noviembre. Con Arbitraje.

$>$ Cuadernos del Centro de Estudios en Diseño y Comunicación. [Ensayos]: Alicia Banchero. Los lugares posibles de la creatividad. Débora Irina Belmes. El desafío de pensar. Creación - recreación. Rosa Judith Chalkho. Transdisciplina y percepción en las artes audiovisuales. Héctor Ferrari. Historietar. Fabián Iriarte. High concept en el escenario del Pitch: Herramientas de seducción en el mercado de proyectos fílmicos. Graciela Pacualetto. Creatividad en la educación universitaria. Hacia la concepción de nuevos posibles. Sylvia Valdés. Funciones formales y discurso creativo. (2004) Buenos Aires: Universidad de Palermo, Facultad de Diseño y Comunicación, Centro de Estudios en Diseño y Comunicación. Vol. 16, junio. Con Arbitraje. 
$>$ Cuadernos del Centro de Estudios en Diseño y Comunicación. [Ensayos]: Adriana Amado Suárez. Internet, o la lógica de la seducción. María Elsa Bettendorff. El tercero del juego. La imaginación creadora como nexo entre el pensar y el hacer. Sergio Caletti. Imaginación, positivismo y actividad proyectual. Breve disgresión acerca de los problemas del método y la creación. Alicia Entel. De la totalidad a la complejidad. Sobre la dicotomía ver-saber a la luz del pensamiento de Edgar Morin. Susana Finquelievich. De la tarta de manzanas a la estética bussines-pop. Nuevos lenguajes para la sociedad de la información. Claudia López Neglia. De las incertezas al tiempo subjetivo. Eduardo A Russo. La máquina de pensar. Notas para una genealogía de la relación entre teoría y práctica en Sergei Eisenstein. Gustavo Valdés. Bauhaus: crítica al saber sacralizado. (2003) Buenos Aires: Universidad de Palermo, Facultad de Diseño y Comunicación, Centro de Estudios en Diseño y Comunicación. Vol. 15, noviembre. Con Arbitraje.

$>$ Cuadernos del Centro de Estudios en Diseño y Comunicación. [Relevamientos Temáticos]: Noemí Galanternik. Tipografía on line. Relevamiento de sitios web sobre tipografía. Marcela Zena. Periódicos digitales en español. Publicaciones periódicas digitales de América Latina y España. (2003) Buenos Aires: Universidad de Palermo, Facultad de Diseño y Comunicación, Centro de Estudios en Diseño y Comunicación. Vol. 14, noviembre. Con Arbitraje.

> Cuaderno: Ensayos. José Guillermo Torres Arroyo. El paisaje, objeto de diseño. (2003) Buenos Aires: Universidad de Palermo, Facultad de Diseño y Comunicación, Centro de Estudios en Diseño y Comunicación. Vol. 13, junio.

> Cuaderno: Recopilación Documental. Centro de Recursos para el Aprendizaje. Relevamientos Temáticos. Series: Práctica profesional. Diseño urbano. Edificios. Estudios de mercado. Medios. Objetos. Profesionales del diseño y la comunicación. Publicidad. (2003) Buenos Aires: Universidad de Palermo, Facultad de Diseño y Comunicación, Centro de Estudios en Diseño y Comunicación. Vol. 12, abril.

$>$ Cuaderno: Proyectos en el Aula. Creación, Producción e Investigación. Proyectos 2003 en Diseño y Comunicación. (2002) Buenos Aires: Universidad de Palermo, Facultad de Diseño y Comunicación, Centro de Estudios en Diseño y Comunicación. Vol. 11, diciembre

> Cuaderno: Proyectos en el Aula. Plan de Desarrollo Académico. Proyecto Anual. Proyectos de Exploración y Creación. Programa de Asistentes en Investigación. Líneas Temáticas. Centro de Recursos. Capacitación Docente. (2002) Buenos Aires: Universidad de Palermo, Facultad de Diseño y Comunicación, Centro de Estudios en Diseño y Comunicación. Vol. 10, septiembre.

> Cuaderno: Proyectos en el Aula: Espacios Académicos. Centro de Estudios en Diseño y Comunicación. Centro de Recursos para el aprendizaje. (2002) Buenos Aires: Universidad de Palermo, Facultad de Diseño y Comunicación, Centro de Estudios en Diseño y Comunicación. Vol. 9, agosto. 
$>$ Cuaderno: Proyectos en el Aula. Adriana Amado Suárez. Relevamiento terminológico en diseño y comunicación. A modo de encuadre teórico. Diana Berschadsky. Terminología en diseño de interiores. Área: materiales, revestimientos, acabados y terminaciones. Blanco, Lorenzo. Las Relaciones Públicas y su proyección institucional. Thais Calderón y María Alejandra Cristofani. Investigación documental de marcas nacionales. Jorge Falcone. De Altamira a Toy Story. Evolución de la animación cinematográfica. Claudia López Neglia. El trabajo de la creación. Graciela Pascualetto. Entre la información y el sabor del aprendizaje. Las producciones de los alumnos en el cruce de la cultura letrada, mediática y cibernética. (2002) Buenos Aires: Universidad de Palermo, Facultad de Diseño y Comunicación, Centro de Estudios en Diseño y Comunicación. Vol. 8, mayo.

> Cuaderno: Relevamiento Documental. María Laura Spina. Arte digital: Guía bibliográfica. (2001) Buenos Aires: Universidad de Palermo, Facultad de Diseño y Comunicación, Centro de Estudios en Diseño y Comunicación. Vol. 7, junio.

> Cuaderno: Proyectos en el Aula. Fernando Rolando. Arte Digital e interactividad. (2001) Buenos Aires: Universidad de Palermo, Facultad de Diseño y Comunicación, Centro de Estudios en Diseño y Comunicación. Vol. 6, mayo.

$>$ Cuaderno: Proyectos en el Aula. Débora Irina Belmes. Del cuerpo máquina a las máquinas del cuerpo. Sergio Guidalevich. Televisión informativa y de ficción en la construcción del sentido común en la vida cotidiana. Osvaldo Nupieri. El grupo como recurso pedagógico. Gustavo Valdés de León. Miseria de la teoría. (2001) Buenos Aires: Universidad de Palermo, Facultad de Diseño y Comunicación, Centro de Estudios en Diseño y Comunicación. Vol. 5 , mayo.

$>$ Cuaderno: Proyectos en el Aula. Creación, Producción e Investigación. Proyectos 2002 en Diseño y Comunicación. (2002) Buenos Aires: Universidad de Palermo, Facultad de Diseño y Comunicación, Centro de Estudios en Diseño y Comunicación. Vol. 4, julio.

> Cuaderno: Papers de Maestría. Cira Szklowin. Comunicación en el Espacio Público. Sistema de Comunicación Publicitaria en la vía pública de la Ciudad de Buenos Aires. (2002) Buenos Aires: Universidad de Palermo, Facultad de Diseño y Comunicación, Centro de Estudios en Diseño y Comunicación. Vol. 3, julio.

$>$ Cuaderno: Material para el aprendizaje. Orlando Aprile. El Trabajo Final de Grado. Un compendio en primera aproximación. (2002) Buenos Aires: Universidad de Palermo, Facultad de Diseño y Comunicación, Centro de Estudios en Diseño y Comunicación. Vol. 2, marzo.

> Cuaderno: Proyectos en el Aula. Lorenzo Blanco. Las medianas empresas como fuente de trabajo potencial para las Relaciones Públicas. Silvia Bordoy. Influencia de Internet en el ámbito de las Relaciones Públicas. (2000) Buenos Aires: Universidad de Palermo, Facultad de Diseño y Comunicación, Centro de Estudios en Diseño y Comunicación. Vol. 1, septiembre. 


\section{Síntesis de las instrucciones para autores}

Cuadernos del Centro de Estudios en Diseño y Comunicación [Ensayos]

Facultad de Diseño y Comunicación. Universidad de Palermo. Buenos Aires, Argentina. www.palermo.edu/dyc

Los autores interesados deberán enviar un abstract de 200 palabras en español, inglés y portugués que incluirá 10 palabras clave. La extensión del ensayo no debe superar las 8000 palabras, deberá incluir títulos y subtítulos en negrita. Normas de citación APA. Bibliografía y notas en la sección final del ensayo.

Presentación en papel y soporte digital. La presentación deberá estar acompañada de una breve nota con el título del trabajo, aceptando la evaluación del mismo por el Comité de Arbitraje y un Curriculum Vitae.

\section{Artículos}

- Formato: textos en Word que no presenten ni sangrías ni efectos de texto o formato especiales.

. Autores: los artículos podrán tener uno o más autores.

. Extensión: entre 25.000 y 40.000 caracteres (sin espacio).

. Títulos y subtítulos: en negrita y en Mayúscula y minúscula.

. Fuente: Times New Roman. Estilo de la fuente: normal. Tamaño: 12 pt. Interlineado: sencillo.

. Tamaño de la página: A4.

. Normas: se debe tomar en cuenta las normas básicas de estilo de publicaciones de la American Psychological Association APA.

. Bibliografía y notas: en la sección final del artículo.

. Fotografías, cuadros o figuras: deben ser presentados en formato tif a 300 dpi en escala de grises. Importante: tener en cuenta que la imagen debe ir acompañando el texto a modo ilustrativo y dentro del artículo hacer referencia a la misma.

\section{Importante:}

La serie Cuadernos del Centro de Estudios en Diseño y Comunicación sostiene la exigencia de originalidad de los artículos de carácter científico que publica.

Es sistema de evaluación de los artículos se realiza en dos partes. En una primera instancia, el Comité Editorial evalúa la pertinencia de la temática del trabajo, para ser publicada en la revista. La segunda instancia corresponde a la evaluación del trabajo por especialistas. Se usa la modalidad de arbitraje doble ciego, permitiendo a la revista mantener la confidencialidad del proceso de evaluación.

Para la evaluación se solicita a los árbitros revisar los criterios de originalidad, pertinencia, actualidad, aportes, y rigurosidad científica. Será el Comité Editorial quien comunica a los autores los resultados de la misma.

\section{Consultas}

En caso de necesitar información adicional escribir a publicacionesdc@palermo.edu o ingresar a http://fido.palermo.edu/servicios_dyc/publicacionesdc/vista/instrucciones.php 



\section{UP \\ Unkarsldad \\ de Palermo}

\section{Facultad de Diseño y Comunicación}

Mario Bravo 1050 . Ciudad Autónoma de Buenos Aires

C1175 ABT . Argentina . www.palermo.edu/dyc 